\title{
Selective functionalization of alicyclic $\beta$-amino acids by 1,3-dipolar cycloaddition of nitrile oxides
}

\author{
PhD Thesis
}

\section{Mária Melinda Nonn}

\author{
Supervisor
}

Prof. Dr. Ferenc Fülöp

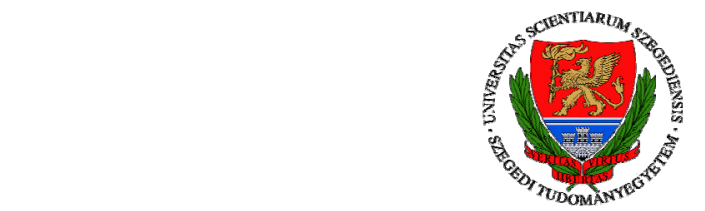

Institute of Pharmaceutical Chemistry, University of Szeged

Szeged, Hungary

2012 


\section{CONTENTS}

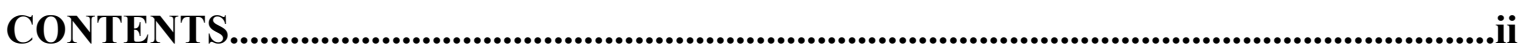

PUBLICATION LIST ...................................................................................................................iii

1. INTRODUCTION AND AIMS.....................................................................................1

\section{LITERATURE BACKGROUND}

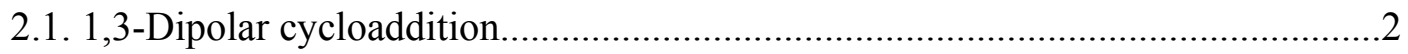

2.2. 1,3-Dipolar cycloaddition of nitrile oxides..........................................................

2.3. Synthetic applications of 1,3-dipolar cycloaddition of nitrile oxides

for the functionalization of $\alpha$ - and $\beta$-amino acid derivatives .....................6

2.4. Synthesis of highly functionalized bioactive amino acids by

1,3-dipolar cycloaddition of nitrile oxides as key step...........................16

\section{RESULTS AND DISCUSSION}

3.1. Synthesis of racemic and enantiomerically pure starting materials

3.2. Synthesis of isoxazoline-fused cispentacin and transpentacin derivatives.

3.3. Regio- and stereoselectivity of 1,3-dipolar cycloaddition to protected cis-and trans-amino ester carboxylates..................................................33

3.4. Isomerization of isoxazoline-fused cycloadducts.................................................38

3.5. Preparation of enantiomerically pure isoxazoline-fused

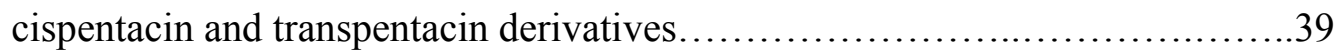

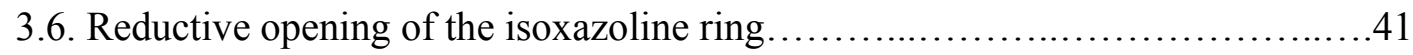

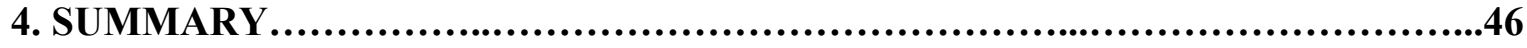

5. ACKNOWLEDGEMENTS..............................................................48

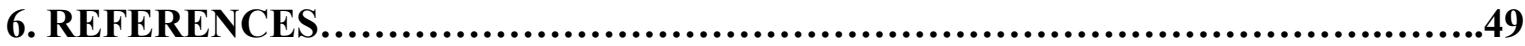

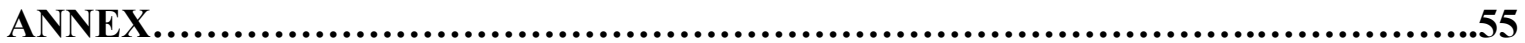




\section{PUBLICATION LIST}

\section{Papers related to the thesis}

I. Loránd Kiss, Melinda Nonn, Enikő Forró Reijo Sillanpää, Ferenc Fülöp Synthesis of novel isoxazoline-fused cispentacin stereoisomers Tetrahedron Lett., 2009, 50, 2605.

II. Melinda Nonn, Loránd Kiss, Enikő Forró, Zoltán Mucsi, Ferenc Fülöp Synthesis of novel isoxazoline-fused cyclic $\beta$-amino esters by regio- and stereoselective 1,3-dipolar cycloaddition Tetrahedron, 2011, 67, 4079.

III. Melinda Nonn, Loránd Kiss, Reijo Sillanpää, Ferenc Fülöp Synthesis of highly functionalized $\beta$-aminocyclopentanecarboxylate stereoisomers by reductive ring opening reaction of isoxazolines Beilstein J. Org. Chem., 2012, 8, 100.

IV. Nonn Melinda, Kiss Loránd, Forró Enikő, Reijo Sillanpää, Mucsi Zoltán, Fülöp Ferenc

Izoxazolin gyürüvel kondenzált ciszpentacin származékok szintézise Magyar Kémiai Folyóirat, submitted for publication

V. Melinda Nonn, Loránd Kiss, Reijo Sillanpää, Ferenc Fülöp Selective nitrile oxide dipolar cycloaddition toward the synthesis of highly functionalized $\beta$-aminocyclohexanecarboxylate stereoisomers Tetrahedron, accepted for publication

VI. Loránd Kiss, Melinda Nonn, Ferenc Fülöp Syntheses of isoxazoline-based amino acids by nitrile oxide cycloaddition and their conversion to highly functionalized bioactive amino acid derivatives Synthesis, 2012, 44, 1951. 


\section{Other publications}

VII. László Sipos, István Ilisz, Melinda Nonn, Ferenc Fülöp, Zoltán Pataj, Daniel W. Armstrong, Antal Péter

High-performance liquid chromatographic enantioseparation of unusual isoxazoline-fused 2-aminocyclopentanecarboxylic acids on macrocyclic glycopeptide-based chiral stationary phases

J. Chromatogr. A., 2012, 1232, 142.

VIII. Jessica A. Howard, Melinda Nonn, Ferenc Fülöp, Thomas J. Wenzel

Enantiomeric discrimination of isoxazoline-fused $\beta$-amino acid derivatives using (18-crown-6)-2,3,11,12-tetracarboxylic acid as a chiral NMR solvating agent Chirality, accepted for publication

IX. László Sipos, István Ilisz, Anita Aranyi, Melinda Nonn, Ferenc Fülöp, Myung Hyun, Antal Péter

High-performance liquid chromatographic enantioseparation of unusual isoxazoline-fused 2-aminocyclopentanecarboxylic acids on (+)-(18-crown-6)2,3,11,12-tetracarboxylic acid-based chiral stationary phases

Chirality, 2012, DOI: 10.1002/chir.22077

\section{Conference lectures}

X. Nonn Melinda, Kiss Loránd, Forró Enikő, Fülöp Ferenc

Izoxazolin gyürüvel kondenzált ciszpentacin származékok szintézise XIV. Nemzetközi Vegyészkonferencia

Cluj Napoca, Romania, 13-15, November, 2008, Abstr.: P52, poster presentation

\section{Nonn Melinda}

Izoxazolin gyürűvel kondenzált ciszpentacin származékok szintézise XXXI. Kémiai Elöadói Napok

Szeged, Hungary, 27-29, October, 2008, Abstr.: p. 105, oral presentation

XII. Nonn Melinda, Kiss Loránd, Forró Enikő, Fülöp Ferenc 
Izoxazolin gyürüvel kondenzált ciszpentacin származékok regio- és

sztereoszelektív szintézise

MTA Heterociklusos Kémiai Munkabizottság Ülése

Balatonszemes, Hungary, 20-22, May, 2009, oral presentation

\section{Nonn Melinda}

$\beta$-Aminosav származékok funkcionalizálása 1,3-dipoláris cikloaddícióval Magyar Tudomány Ünnepe - PhD hallgatóink eredményei

Szeged, Hungary, 10, November, 2009, oral presentation

XIV. Melinda Nonn, Loránd Kiss, Enikő Forró, Ferenc Fülöp

Regio- and stereoselective 1,3-dipolar cycloaddition of nitrile oxides to ethyl cisor trans-2-aminocyclopent-3-enecarboxylates

COST Action CM0803. Foldamers: Building blocks, structure and function

Szeged, Hungary, 24-26, September, 2009, Abstr.: P03, p. 31, poster presentation

XV. Nonn Melinda, Kiss Loránd, Forró Enikő, Fülöp Ferenc

Izoxazolin gyürüvel kondenzált ciklusos $\beta$-aminosav származékok szelektív

szintézise

MTA Heterociklusos Kémiai Munkabizottság Ülése

Balatonszemes, Hungary, 19-21, May, 2010, oral presentation

XVI. Gert Callebaut, Sven Mangelinckx, Melinda Nonn, Loránd Kiss, Ferenc Fülöp, Norbert De Kimpe

Synthesis of $\alpha$-hydroxy- $\beta, \gamma$-aziridino esters via stereoselective Mannich-type

addition of Boc-protected glycolate esters across chiral $N$-sulfinyl

$\alpha$-chloroaldimines

$14^{\text {th }}$ SIGMA-ALDRICH Organic Synthesis Meeting

Sol Cress-Spa, Belgium, 2-3, December, 2010, poster presentation

XVII. Melinda Nonn, Gert Callebaut, Swen Mangelinckx, Loránd Kiss, Reijo Sillanpää, Ferenc Fülöp, Norbert De Kimpe

Stereoselective Mannich-type reaction of O-protected glycolate esters across $\mathrm{N}$ sulfinyl $\alpha$-chloro aldimines. Synthesis of $\alpha$-hydroxy- $\beta, \gamma$-aziridino ester derivatives Foldamers: Synthesis and Structure of Functional Materials

Barcelona, Spain, 7-9, April, 2011, Abstr.: OC8, p. 24, oral presentation 
XVIII. Melinda Nonn, Loránd Kiss, Reijo Sillanpää, Ferenc Fülöp Synthesis of highly functionalized $\beta$-aminocyclopentane- or cyclohexanecarboxylate stereoisomers via selective nitrile oxide dipolar cycloaddition $X I V^{\text {th }}$ Conference on Heterocycles in Bio-organic Chemistry Brno, Czech Republic, 4-8, September, 2011, Abstr.: P23 , poster presentation XIX. Nonn Melinda, Gert Callebaut, Swen Mangelinckx, Kiss Loránd, Reijo Sillanpää, Norbert De Kimpe, Fülöp Ferenc $\alpha$-Hidroxi- $\beta, \gamma$-aziridin származékok szintézise MTA Heterociklusos Kémiai Munkabizottság Ülése Balatonszemes, Hungary, 26-28, September, 2011, oral presentation 


\section{INTRODUCTION AND AIMS}

Thanks to their useful biological properties, alicyclic $\beta$-amino acids have attracted considerable interest during the past twenty years. They are present in many natural products. Some naturally occurring derivatives, such as the antifungal cispentacin and icofungipen and the antibacterial oryzoxymycin, are interesting bioactive members of this class of compounds. Cyclic $\beta$-amino acids are also of paramount importance in peptide chemistry, since they can be used as building blocks for the preparation of modified biologically active peptide analogues. Carbocyclic $\beta$-amino acids are additionally used as starting substances for the synthesis of heterocyclic compounds, potential pharmacons and natural product analogues. Their enantiomerically pure forms can serve as chiral auxiliaries in asymmetric transformations. ${ }^{1-32}$

One of the main research topics at the Institute of Pharmaceutical Chemistry, University of Szeged, is the synthesis of highly functionalized cyclic $\beta$-amino acids. A number of scientific articles have been published in recent years on the selective formation of new functional groups (hydroxy, dihydroxy, amino, azido and fluoro) on cyclic $\beta$-amino acids. $^{33-42}$ 1,3-Dipolar cycloaddition is a powerful technique for the functionalization of a $\mathrm{C}-\mathrm{C}$ double bond. The $\mathrm{C}-\mathrm{C}$ double bond in protected cyclic $\beta$-amino acids may be utilized as a dipolarophile in a 1,3-dipolar cycloaddition in order to synthetize different functionalized derivatives.

Accordingly, my $\mathrm{PhD}$ work focused on the regio- and stereoselective 1,3-dipolar cycloaddition of nitrile oxides to cyclic $\beta$-amino acid derivatives. The aim was to study the regio- and stereoselectivity of the cycloaddition of nitrile oxides to protected five- or sixmembered cyclic $\beta$-amino esters, and $\mathrm{N}-\mathrm{O}$ cleavage of the isoxazoline ring for the synthesis of highly functionalized cyclic $\beta$-amino acids. Moreover, cycloadducts were prepared in enantiomerically pure form through appropriate enzymatic resolution of bicyclic $\beta$-lactams. 


\section{LITERATURE BACKGROUND}

\subsection{1,3-Dipolar cycloaddition}

The idea of 1,3-dipolar cycloaddition was suggested by Smith in $1938,{ }^{43}$ but this possibility became widely applicable only after 1960, when the reaction was generalized by Huisgen. ${ }^{44,45}[4 \pi \mathrm{s}+2 \pi \mathrm{s}]$ Cycloaddition is achieved between a dipolarophile (e.g. alkenes, alkynes, carbonyls and nitriles) and a 1,3-dipolar agent (Scheme 1).

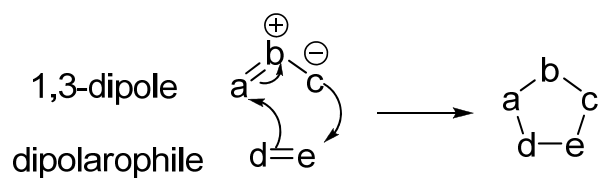

Scheme 1. General scheme of 1,3-dipolar cycloaddition.

The 1,3-dipoles form a three-atom $\pi$-electron system, with four $\pi$-electrons delocalized over the three atoms. Some important 1,3-dipoles are: nitrile oxides, nitrones, azides, nitrile imines, diazoalkanes, carbonyl ylides and nitrile ylides. ${ }^{46}$

1,3-Dipoles can be divided into two types: the allyl type, e.g. nitrones, azomethine ylides, azomethine imines, carbonyl ylides and carbonyl imines, and the propargyl-allenyl type, e.g. nitrile oxides, nitrile imines, nitrile ylides, diazoalkanes and azides. The allyl type contains four electrons in three parallel $p_{z}$ orbitals perpendicular to the plane of the dipole. 1,3-Dipoles of the allyl type are bent, whereas a double bond orthogonal to the delocalized $\pi$-system in the propargyl-allenyl type confers linearity on the dipole (Scheme 2).

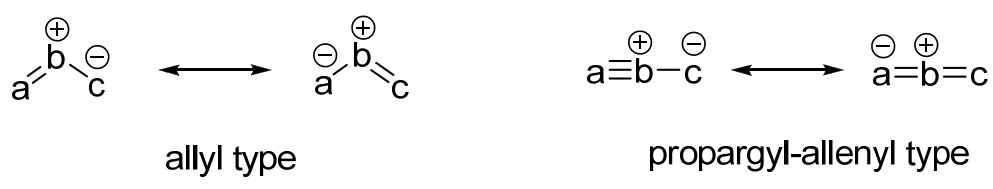

Scheme 2. Classification of 1,3-dipoles.

The dipolarophiles may contain double or triple bond functionalities such as $\mathrm{C} \equiv \mathrm{C}$, $\mathrm{C}=\mathrm{C}, \mathrm{C} \equiv \mathrm{N}, \mathrm{C}=\mathrm{N}, \mathrm{C}=\mathrm{O}$ and $\mathrm{C}=\mathrm{S}$. The $\pi$-bond may be isolated, conjugated or part of a cumulene system. The presence of functional groups on the dipolarophile can influence the reactivity of 1,3-dipolar cycloaddition. For example, a combination of electron-withdrawing 
and electron-donating groups in one molecule results in a dipolarophile of low reactivity. The presence of only one type of group (electron-withdrawing or electron-donating) leads to higher reactivity with 1,3-dipoles. ${ }^{47,48}$ The cycloaddition of 1,3-dipoles to dipolarophiles may occur in a synchronous, concerted process, as suggested by Huisgen, or in a stepwise, diradical pathway, which was preferred by Firestone (Scheme 3). ${ }^{47}$

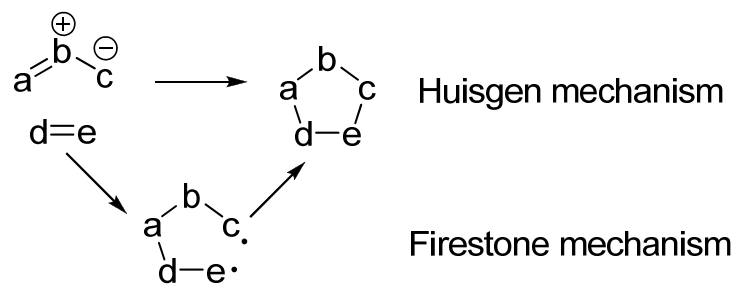

Scheme 3. Alternative mechanisms of 1,3-dipolar cycloaddition.

\subsection{1,3-Dipolar cycloaddition of nitrile oxides}

The 1,3-dipolar cycloaddition of nitrile oxides to alkenes is a typical, well-adaptable method for the synthesis of isoxazolines, ${ }^{49-56}$ which are important heterocyclic compounds in medicinal chemistry, since a number of substituted isoxazolines exhibit anti-influenza activities and antifungal properties. ${ }^{57-67}$ Nitrile oxides are usually not stable dipoles, and they are therefore synthetized in situ in the reactions. They can be generated from hydroximoyl halides $(\mathrm{X}=\mathrm{Br}, \mathrm{Cl})(\mathbf{3})$, from aldoximes $(2)^{68}$ or from primary nitroalkanes $(4){ }^{69}$ Stable, non-dimerizing nitrile oxides can often rearrange to isocyanates at high temperature (5), and non-stable dipoles can dimerize to furoxans $(6)^{70}$ (Scheme 4$)$. 


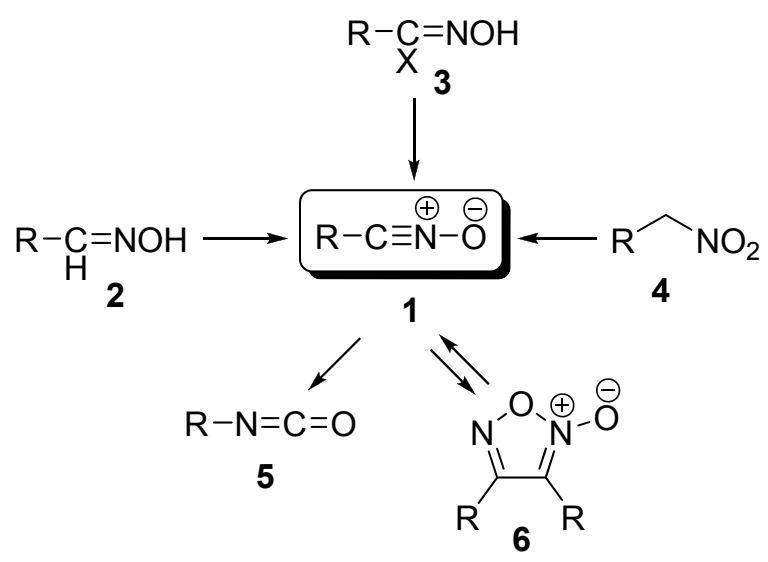

Scheme 4. Generation and transformations of nitrile oxides.

Accordingly, through the dehydrohalogenation of hydroximoyl chlorides, known as the Huisgen procedure, nitrile oxides can be prepared from oximes in two steps: halogenation of the aldoxime to furnish a hydroximoyl halide, followed by a dehydrohalogenation with base. In the presence of electron-withdrawing groups, aldoximes can additionally be oxidized to nitrile oxides. This reaction is carried out with $\mathrm{MnO}_{2}$. Another method that is frequently used for the in situ generation of nitrile oxides is the dehydration of nitroalkanes, introduced by Hoshino and Mukaiyama in 1960, which is performed in the presence of a catalytic amount of base. The dehydration agents used are phenyl isocyanate (PhNCO), di-tert-butyl dicarbonate $\left(\mathrm{Boc}_{2} \mathrm{O}\right)$, ethyl chloroformate, dimethylaminosulfur trifluoride (DAST), $\mathrm{Ac}_{2} \mathrm{O}$, etc. In general, the base is $\mathrm{Et}_{3} \mathrm{~N}$, but in some cases 4-dimethylaminopyridine (DMAP) is also used under milder conditions. A possible mechanism for the generation of a nitrile oxide from a primary nitroalkane is shown in Scheme 5.

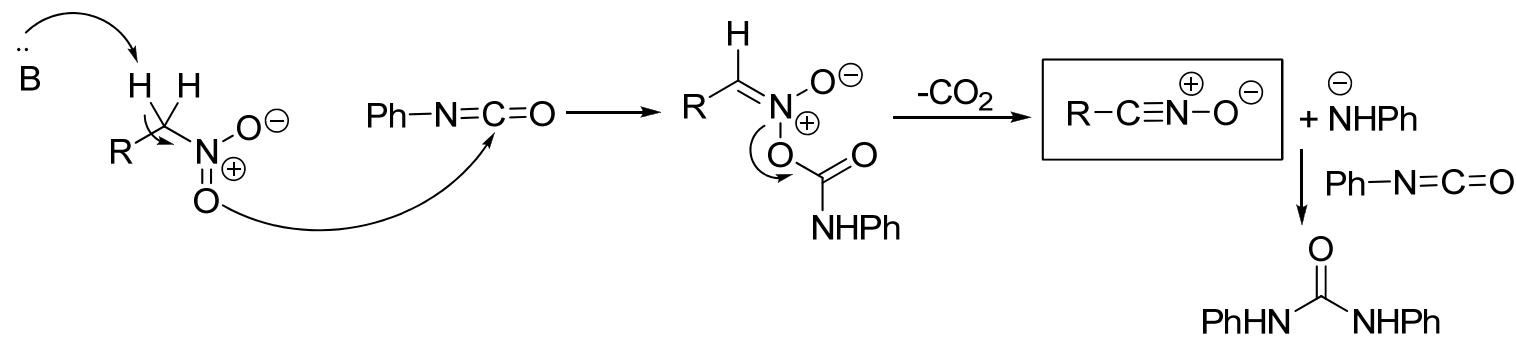

Scheme 5. Mechanism of preparation of nitrile oxides from primary nitroalkanes in the presence of PhNCO. 
Cycloaddition of a nitrile oxide to a substituted olefin can lead to two regioisomers, either the 3,4-disubstituted or the 3,5-disubstituted cycloadduct (Scheme 6); steric and electronic effects influence the regioselectivity. In the presence of strong electronwithdrawing substituents, the 3,4-disubstituted isoxazoline is favoured.

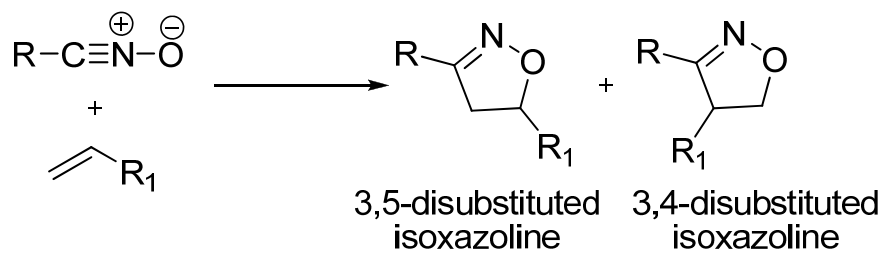

Scheme 6. 1,3-Dipolar cycloaddition of nitrile oxides to substituted olefins.

When electron-rich and conjugated alkenes are used in the cycloaddition, the regioselectivity is dipole-LUMO-controlled. Accordingly, the carbon atom of the nitrile oxide attacks the terminal carbon atom of the alkene and results in the 3,5-disubstituted isoxazoline alone. Cycloaddition to electron-deficient dipolarophiles yields a mixture of regioisomers, and both the dipole-HOMO and dipole-LUMO interactions are significant. In general, mixtures of regioisomers are formed during the 1,3-dipolar cycloaddition of nitrile oxides to disubstituted alkenes. ${ }^{47}$

Isoxazolines are of considerable importance in synthetic chemistry since they are precursors of iminoalcohols, hydroxyketones, aminoalcohols and amino acids (Scheme 7). ${ }^{71-78}$

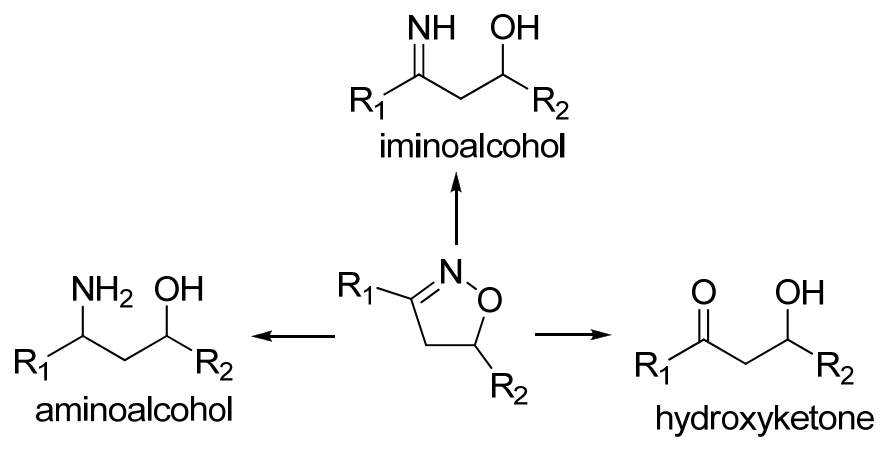

Scheme 7. Some useful transformations of isoxazolines. 


\subsection{Synthetic applications of 1,3-dipolar cycloaddition of nitrile oxides for the functionalization of $\alpha$-and $\gamma$-amino acid derivatives}

The applications of 1,3-dipolar cycloaddition in organic synthesis, and in particular the use of nitrile oxides as dipolarophiles, have undergone continuous development in recent years. A number of research groups have published interesting results and some of the major developments are summarized below. Quadrelli and co-workers have recently published a number of articles on this topic. ${ }^{79-86}$ They have developed the synthesis of isoxazolinecarbocyclic nucleosides via the 1,3-dipolar cycloaddition of nitrile oxides. The nucleoside precursors 12 were prepared from cyclopentadiene 7 (Scheme 8). ${ }^{82,83}$
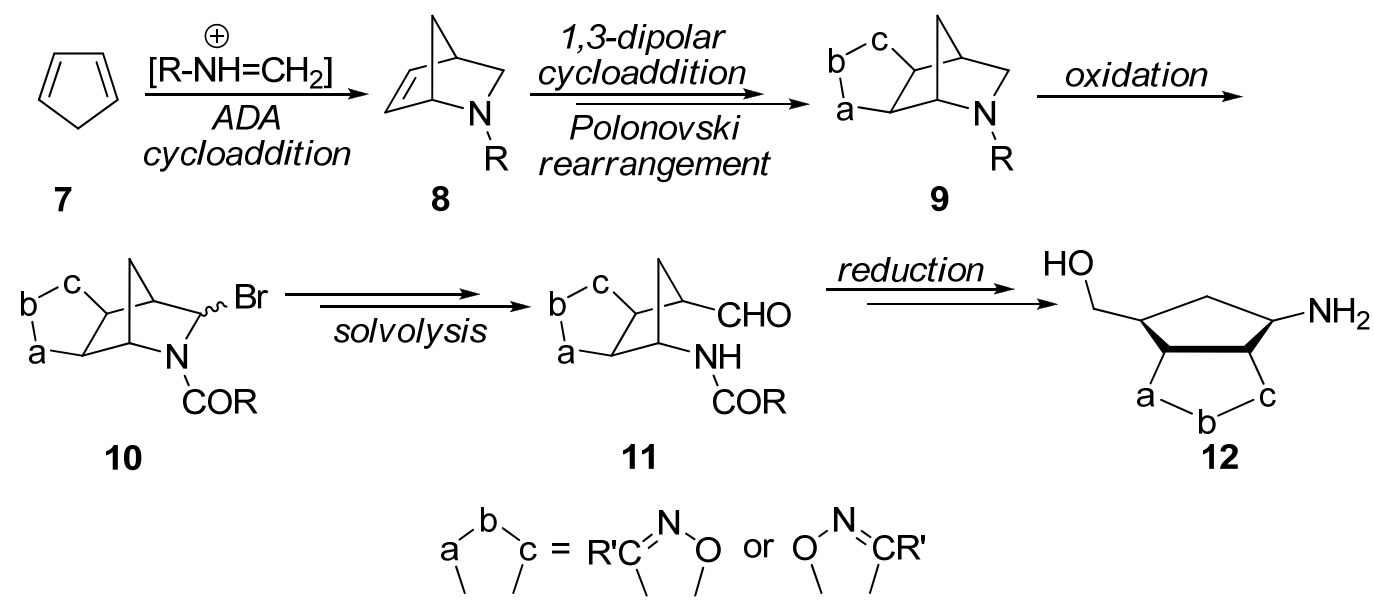

Scheme 8. Synthesis of isoxazoline-fused carbocyclic amino alcohols $\mathbf{1 2}$.

2-Azanorborn-5-enes $\mathbf{8}$ were prepared via the Grieco cycloaddition of cyclopentadiene 7 to iminium salts generated in situ under Mannich-like conditions, in an aza-Diels-Alder reaction (ADA). These adducts are quite reactive dipolarophiles and in 1,3-dipolar cycloadditions give exclusively exo adducts 9. The synthetic steps outlined in Scheme 8 were followed for the preparation of the target aminols 12 through intermediates 10 and 11. Benzonitrile oxide was generated in situ from benzhydroximoyl chloride $\mathbf{1 4}$ in dichloromethane (DCM) solution in the presence of $\mathrm{Et}_{3} \mathrm{~N}$ (Scheme 9). 
<smiles>c1ccc([PH2+]c2ccccc2)cc1</smiles>

13<smiles>CCN(O)CCN(CC)CC</smiles>

14

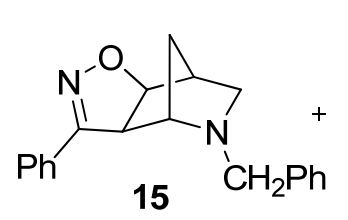

$(49 \%)$<smiles>c1ccc(-c2noc3c2C2CNC3C2)cc1</smiles>

$16 \mathrm{CH}_{2} \mathrm{Ph}$

$(43 \%)$

Scheme 9. 1,3-Dipolar cycloaddition of benzonitrile oxide to $N$-benzyl-2-azanorborn-

\section{5-ene 13.}

The cycloaddition reaction of $\mathbf{1 4}$ to $\mathbf{1 3}$ resulted in two regioisomeric isoxazoline cycloadducts, $\mathbf{1 5}$ and $\mathbf{1 6}$, in a regioisomeric ratio of close to 1:1. It was reported that the regioselectivity is higher in protic alcohols than in other dipolar and polarizable solvents.

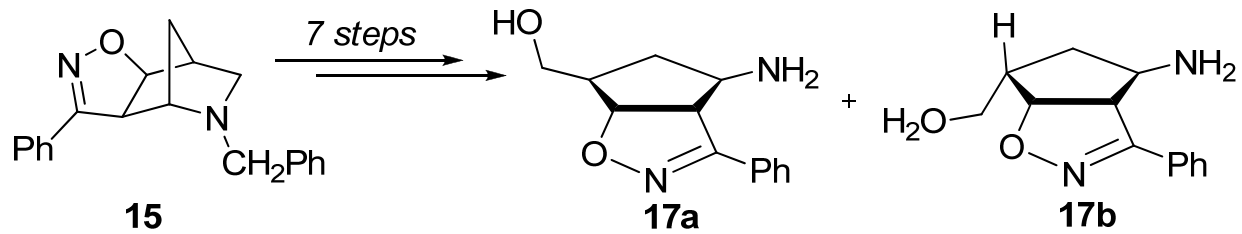

15

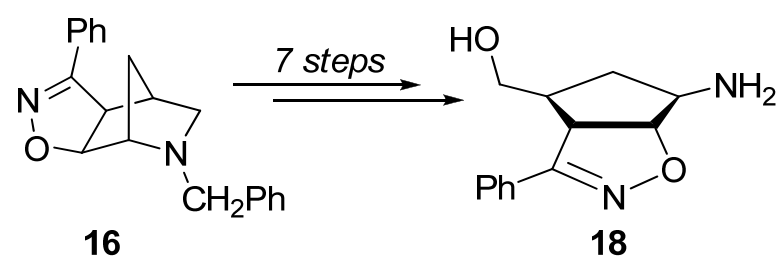

Scheme 10. Synthesis of isoxazoline-carbocyclic amino alcohols.

Finally, three regio- and stereoisomeric amino alcohols, 17a, 17b and 18, were synthetized in good yields through the exo-selective 1,3-dipolar cycloaddition of benzonitrile oxide to $\mathrm{N}$-benzyl-2-azanorborn-5-ene; these derivatives are useful precursors for nucleoside preparation (Scheme 10). The isoxazoline-carbocyclic nucleosides have been tested as potential antiviral agents against herpes simplex virus types 1 and $2 .^{82,83}$

The same research group also applied isoxazoline-2-azanorbornanes $(\mathbf{1 5}, \mathbf{1 6})$ for the preparation of lactam derivatives as precursors of peptidomimetic $\gamma$-amino acids, by $\mathrm{RuO}_{4}$-catalysed oxidation. ${ }^{84}$ The oxidation was performed by using the catalytic system $\mathrm{RuO}_{2} / \mathrm{NaIO}_{4}$ under $\mathrm{H}_{2} \mathrm{O} /$ EtOAc biphasic conditions (Scheme 11). 


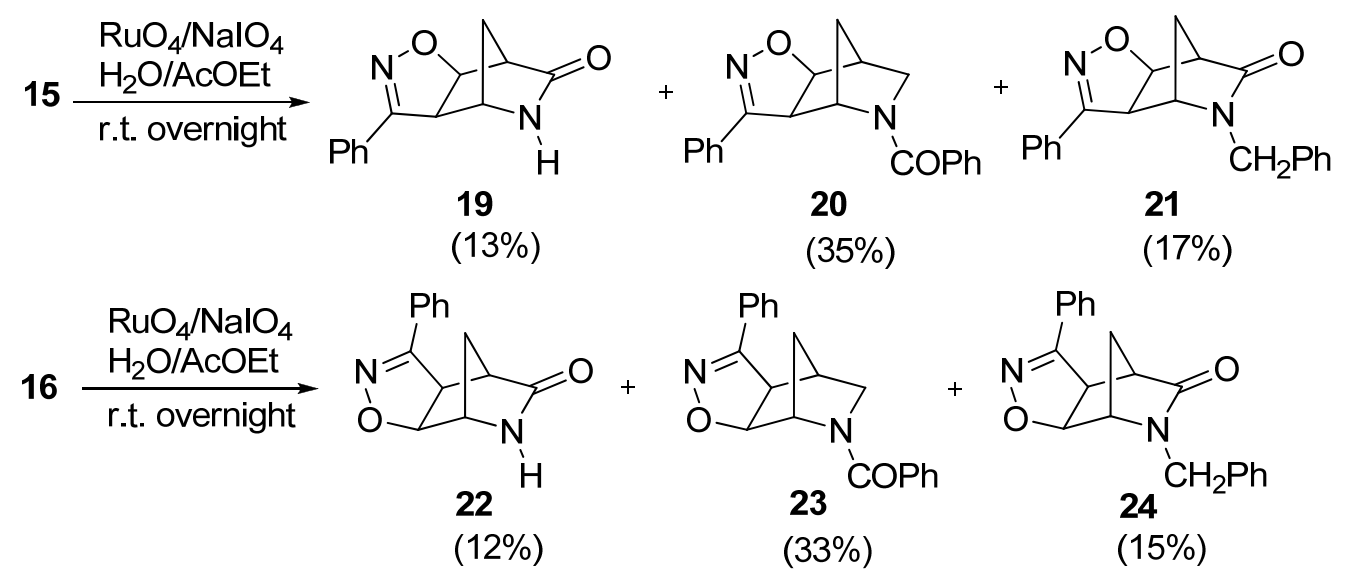

Scheme 11. Oxidation of compounds 15 and 16 to isoxazoline-fused lactams.

Compounds 20 and 23 were the major products obtained by oxidation of the more reactive benzylic group. Oxidation of $\mathrm{C} 3$ in the azanorbornene moiety furnished $N$-benzyl lactams 21 and 24 and lactams 19 and 22, which were also isolated. The desired $\gamma$-amino acids 25 and 26 were prepared by the hydrolysis of lactams 19 and 22 in the presence of methanesulfonic acid (MSA) (Scheme 12).<smiles>O=C1NC2CC1C1ON=C(c3ccccc3)C21</smiles>

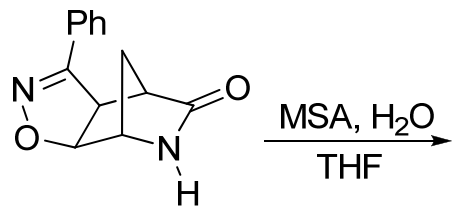
22<smiles>O=C(O)C1CC2ON=C(c3ccccc3)C2C1[NH2+][Na]</smiles>

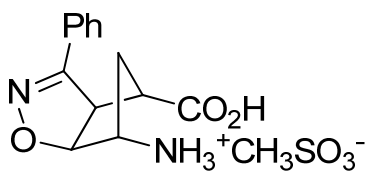

26 $(100 \%)$

Scheme 12. Preparation of $\gamma$-amino acids 25 and 26.

Glutamate is an important neurotransmitter in the mammalian central nervous system and is significant for learning and memory. Overactivation of the glutamatergic synapses causes neurotoxicity, typically associated with acute and chronic neurodegenerative disease, e.g. cerebral ischaemia, epilepsy, amyotrophic, lateral sclerosis, and Parkinson's and Alzheimer's diseases. One of the main research topics of Conti and co-workers is the 
synthesis of novel homologues of glutamic acid. ${ }^{87-91}$ The key step in the synthesis of target compounds $\mathbf{3 4}$ and $\mathbf{3 5}$ is the 1,3-dipolar cycloaddition of ethoxycarbonylformonitrile oxide, generated in situ by the treatment of 29 with base (Scheme 13). ${ }^{87}$

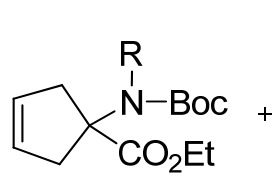

27: $\mathrm{R}=\mathrm{H}$

28: $R=B o c$<smiles>CCOC(=O)C(Cl)=NC(Cl)C(=O)OCC</smiles>

29

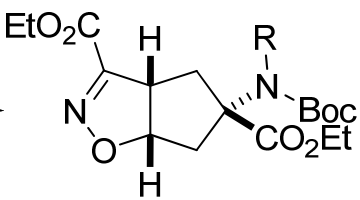

( \pm -30: $\mathrm{R}=\mathrm{H}(84 \%)$

$( \pm)-31: R=\operatorname{Boc}(33 \%)$<smiles>CC=C[C@@H]1C[C@@H]2C(CO)=NO[C@@H]2CC1(N)C(=O)O</smiles>

34<smiles>[R]OC(=O)N([R])[C@]1(C(=O)O[Z10])C[C@H]2ON=C(COCC)[C@H]2C1</smiles>

( \pm -32: $\mathrm{R}=\mathrm{H}(16 \%)$

$( \pm)-33: R=\operatorname{Boc}(67 \%)$

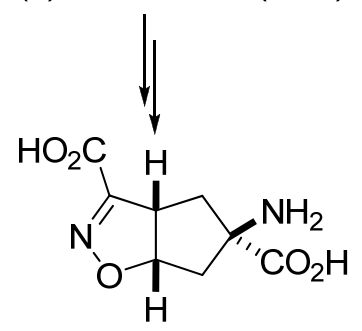

35

Scheme 13. 1,3-Dipolar cycloaddition of nitrile oxide 29 to cyclic $\alpha$-aminocarboxylates 27 and 28.

The reaction of $\mathbf{2 7}$ gave two stereoisomers, $( \pm)-\mathbf{3 0}$ and $( \pm)-\mathbf{3 2}$, in a ratio of 84:16. The selectivity of this reaction was explained by the H-bonding interaction between the carbamate and the nitrile oxide (Figure 1). ${ }^{93}$<smiles>CCOC(=O)c1noc2c1C[C@@H]1C[C@H]2N(C(=O)OCc2ccccc2)C1OCC</smiles>

Figure 1. Transition state stabilized by an intermolecular H-bond in 1,3-dipolar cycloaddition.

This explanation was supported by determination of the structure of the major product ( \pm )-30 by X-ray analysis and theoretical calculations. When $\mathbf{2 8}$ was used as dipolarophile, the selectivity of the 1,3-dipolar cycloaddition (31/33) was 33:67. In this case, the selectivity was due to both the steric effect and the absence of the H-bonding interaction. Finally, amino 
acids 34 and $\mathbf{3 5}$ were obtained by removal of the protecting groups (Scheme 13). The products were tested in vitro by means of receptor-binding techniques, second messenger assays and electrophysiological studies; they proved to behave as anticonvulsant agents. ${ }^{87}$

In other work, 1,3-dipolar cycloaddition of ethoxycarbonylformonitrile oxide to methyl $\quad N$-(tert-butoxycarbonyl)-1-aminocyclopent-3-enecarboxylate was achieved (Scheme 14). ${ }^{88}$<smiles>CC(=O)OCC1(NC(=O)OCc2ccccc2)CC=CC1</smiles><smiles>CCOC(=O)NCCC(=O)OCC(=O)O</smiles>

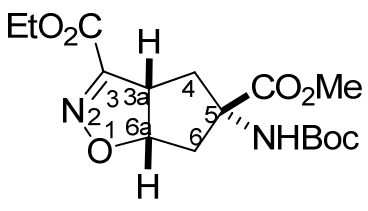

$( \pm)-37(82 \%)$<smiles>CCOC(=O)N[C@]1(C(=O)OC)C[C@H]2ON=C(COC)[C@H]2C1</smiles>

$( \pm)-\mathbf{3 8}(18 \%)$

Scheme 14. Preparation of racemic cycloadducts 37 and 38.

The synthesis of cycloadducts $( \pm)-\mathbf{3 7}$ and $( \pm)$-38 was extended to their preparation in enantiomerically pure form by enzymatic kinetic resolution (Scheme 15).<smiles>CCOCC1NOC2CC(NC(C)=O)CC12NC(=O)OCC</smiles>

$( \pm)-37$<smiles>CCOCC1=NO[C@H]2C[C@H](NC(=O)OCC)C[C@H]12</smiles>

$( \pm)-38$

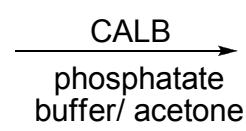

buffer/ acetone

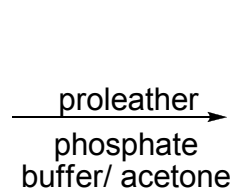

$( \pm)-38$

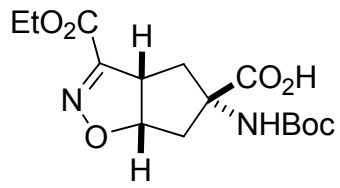

$(-)-(3 a S, 5 S, 6 a S)-39$<smiles>CCOCC1=NO[C@@H]2C[C@@](NC(=O)O)(C(=O)O)C[C@H]12</smiles>

$(+)-(3 \mathrm{a} R, 5 S, 6 \mathrm{a} R)-40$<smiles>CCOCC1=NOC2CC(NC(C)=O)(C(C)=O)CC12</smiles>

$(+)-(3 \mathrm{a} R, 5 R, 6 \mathrm{a} R)-37$

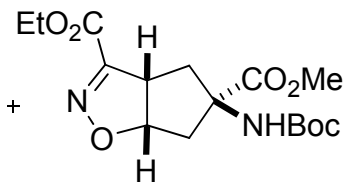

$(-)-(3 \mathrm{a} S, 5 R, 6 \mathrm{a} S)-38$

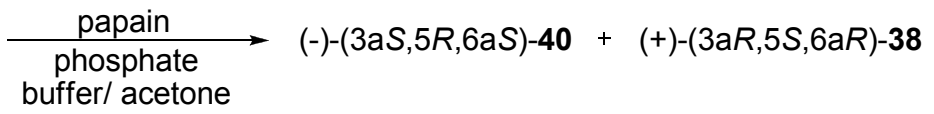

Scheme 15. Kinetic resolution of compounds $( \pm)-37$ and $( \pm)-38$.

Diesters $( \pm)$-37 and $( \pm)$-38 were subjected to hydrolysis with catalysis by lipase B from Candida antartica (CALB). Papain catalysed the hydrolysis of diester $( \pm)$-38 to monoacid (-)-40, whereas proleather converted $( \pm)-38$ into enantiomer (-)-38 and (+)-40. 
All stereoisomers were isolated and were then transformed into the related final amino acids (-)-34 and (-)-35 by standard reactions (Scheme 13). ${ }^{88}$

Conti and co-workers synthetized novel isoxazoline-containing glutamate derivatives (41a-44b) with increased conformational rigidity of the pharmacophoric groups (Scheme 16). ${ }^{89}$

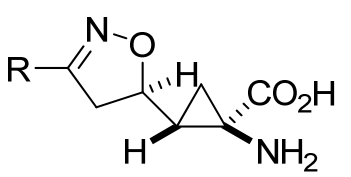

$\mathrm{R}=\mathrm{CO}_{2} \mathrm{H} ;( \pm)-\mathbf{4 1 a}$

$\mathrm{R}=\mathrm{OH} ;( \pm)-42 \mathrm{a}$

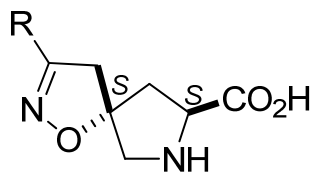

$\mathrm{R}=\mathrm{OH} ;(5 S, 8 S)-\mathbf{4 3 b}$

$\mathrm{R}=\mathrm{CO}_{2} \mathrm{H}$; $(5 S, 8 S)-\mathbf{4 4 b}$<smiles>[R]C1=NO[C@@]2(C1)C[C@]2(N)C(=O)O</smiles>

$\mathrm{R}=\mathrm{CO}_{2} \mathrm{H} ;( \pm)-\mathbf{4 1 b}$

$\mathrm{R}=\mathrm{OH} ;( \pm)-\mathbf{4 2 b}$

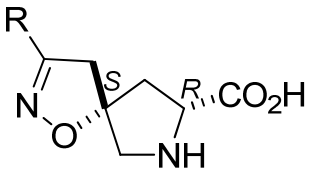

$\mathrm{R}=\mathrm{OH} ;(5 S, 8 R)-43 \mathrm{a}$

$\mathrm{R}=\mathrm{CO}_{2} \mathrm{H} ;(5 S, 8 R)-44 \mathrm{a}$

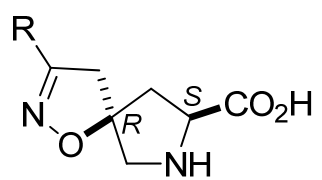

$\mathrm{R}=\mathrm{OH} ;(5 R, 8 S)-\mathbf{4 3 a}$

$\mathrm{R}=\mathrm{CO}_{2} \mathrm{H} ;(5 R, 8 S)-\mathbf{4 4 a}$

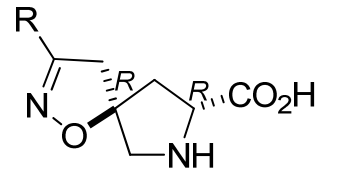

$\mathrm{R}=\mathrm{OH} ;(5 R, 8 R)-43 \mathrm{~b}$

$\mathrm{R}=\mathrm{CO}_{2} \mathrm{H} ;(5 R, 8 R)-44 \mathrm{~b}$

Scheme 16. Isoxazoline-containing glutamate analogues.

In the first set of compounds $(41 \mathbf{a}, \mathbf{b}$ and $\mathbf{4 2 a}, \mathbf{b})$ the amino acidic moiety is attached to a cyclopropane ring, whereas in the second set of derivatives (43a,b and $44 \mathbf{a}, \mathbf{b})$ a spirocyclic 3-hydroxyisoxazoline ring is linked to a proline skeleton. Racemic isoxazoline-containing compounds $( \pm)$-46a and $( \pm)$-46b were synthetized by 1,3-dipolar cycloaddition between compound 31 and dipolarophile ( \pm )-45 (Scheme 17).

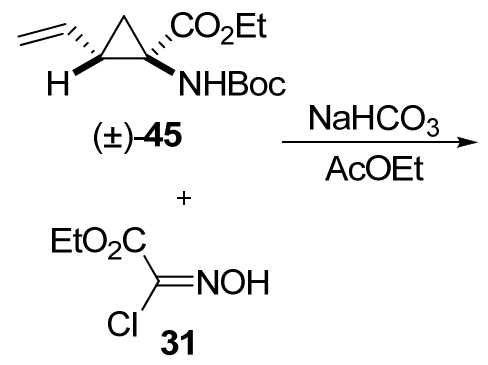

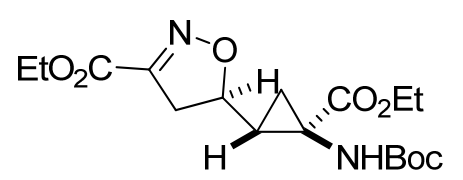

$( \pm)-46 \mathbf{a}(14 \%)$

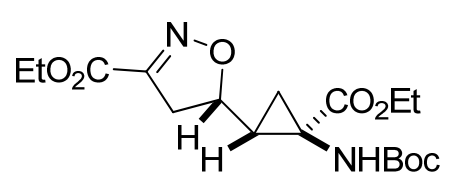

$( \pm)-46 b(23 \%)$

Scheme 17. Synthesis of compounds $( \pm)-\mathbf{4 6 a}, \mathbf{b}$.

Cycloaddition with compound 47 as nitrile oxide precursor furnished two stereoisomers, $( \pm)-\mathbf{4 8 a}$ and $( \pm)-\mathbf{4 8 b}$ (Scheme 18). 


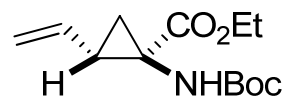<smiles>ON=C(Br)Br</smiles>

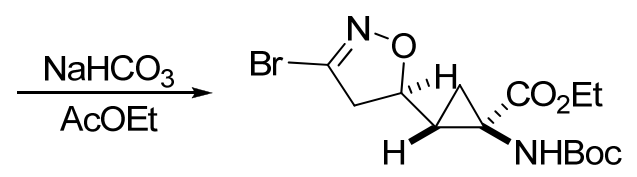

$( \pm)-48 a(65 \%)$

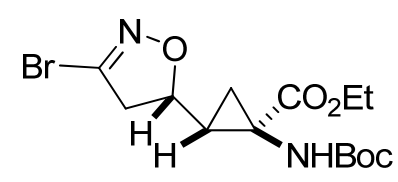

$( \pm)-\mathbf{4 8 b}(25 \%)$

Scheme 18. Preparation of compounds $( \pm)-48 a, b$.

The synthetic strategy described above was also applied for the preparation of enantiomerically pure spirocyclic derivatives $\mathbf{5 0 a}, \mathbf{b}$ and $\mathbf{5 1 a}, \mathbf{b}$. The 1,3-dipolar cycloaddition was performed between ethoxycarbonylformonitrile oxide or bromonitrile oxide and (S)-49. In the course of the reaction, a mixture of stereoisomers was formed in a ratio of 1:3 (50a:50b) or 1:4 (51a:51b) (Scheme 19).

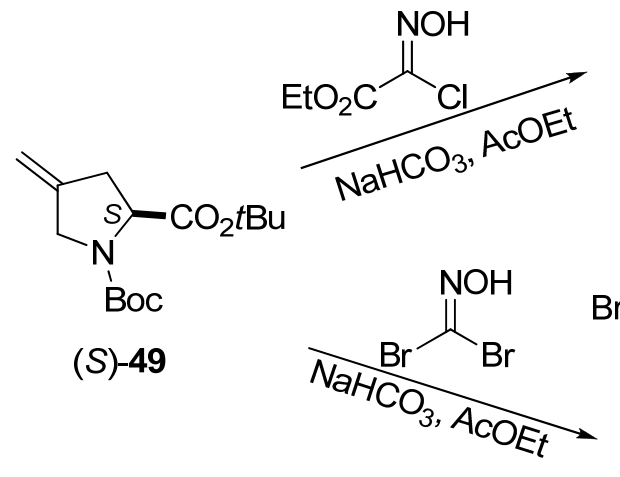

$(S)-49$<smiles>CCOC(=O)C1=NOC2(C1)CC(COC(=O)OCc1ccccc1)N(C(=O)OCc1ccccc1)C2</smiles>

$(5 R, 8 S)-50 a$<smiles>CCOC(=O)C1=CC[C@]2(CC(Br)=NO2)CN1C(=O)OC(C)(C)C</smiles>

$(5 R, 8 S)-51 a$<smiles>CCOC(=O)OCC1C[C@]2(CC(C(=O)OCC)=NO2)CN1C(=O)OCc1ccccc1</smiles>

$(5 S, 8 S)-50 b$<smiles>CC(C)(C)OC(=O)C1=C(C(=O)OC(C)(C)C)CC2(CC(Br)=NO2)C1</smiles>

$(5 S, 8 S)-51 b$

Scheme 19. Syntheses of spirocyclic isoxazoline-containing compounds.

The reactions were also performed by starting from the $R$ enantiomer $[(R)-49]$ with ethoxycarbonylformonitrile oxide or bromonitrile oxide, when two stereoisomers, $\mathbf{5 0 a}, \mathbf{b}$ and 51a,b, were isolated (Scheme 20). 


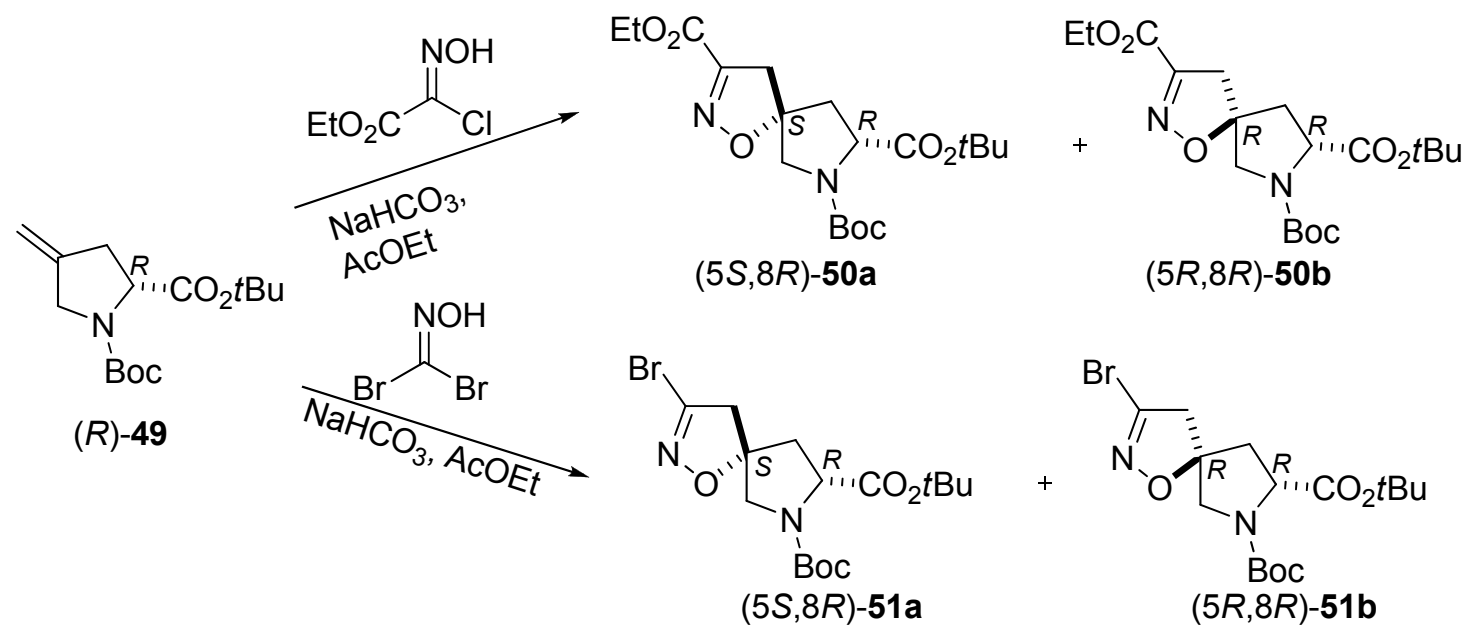

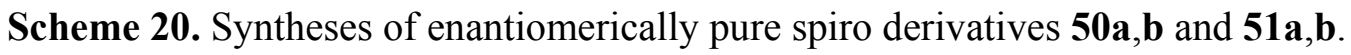

The resulting cycloadducts were transformed into the target amino acids (Scheme 16) by deprotection of the amino group, transformation of the halogen to the hydroxy group and hydrolysis of the ester function. ${ }^{89}$

Kurth and co-workers prepared hydantoin-containing isoxazoline derivatives. ${ }^{92,93}$ The hydantoin nucleus is an important motif in medicinal and agrochemistry. For the preparation of the dipolarophile, cyclopentenecarboxylate $\mathbf{5 2}$ was used, which was treated with aqueous $\mathrm{HCl}$ in $\mathrm{THF}$, followed by aqueous $\mathrm{NaOH}$ to afford amino ester 53. Reaction of $\mathbf{5 3}$ with aryl nitrile oxides yielded 54-56 (Scheme 21). ${ }^{92}$ 


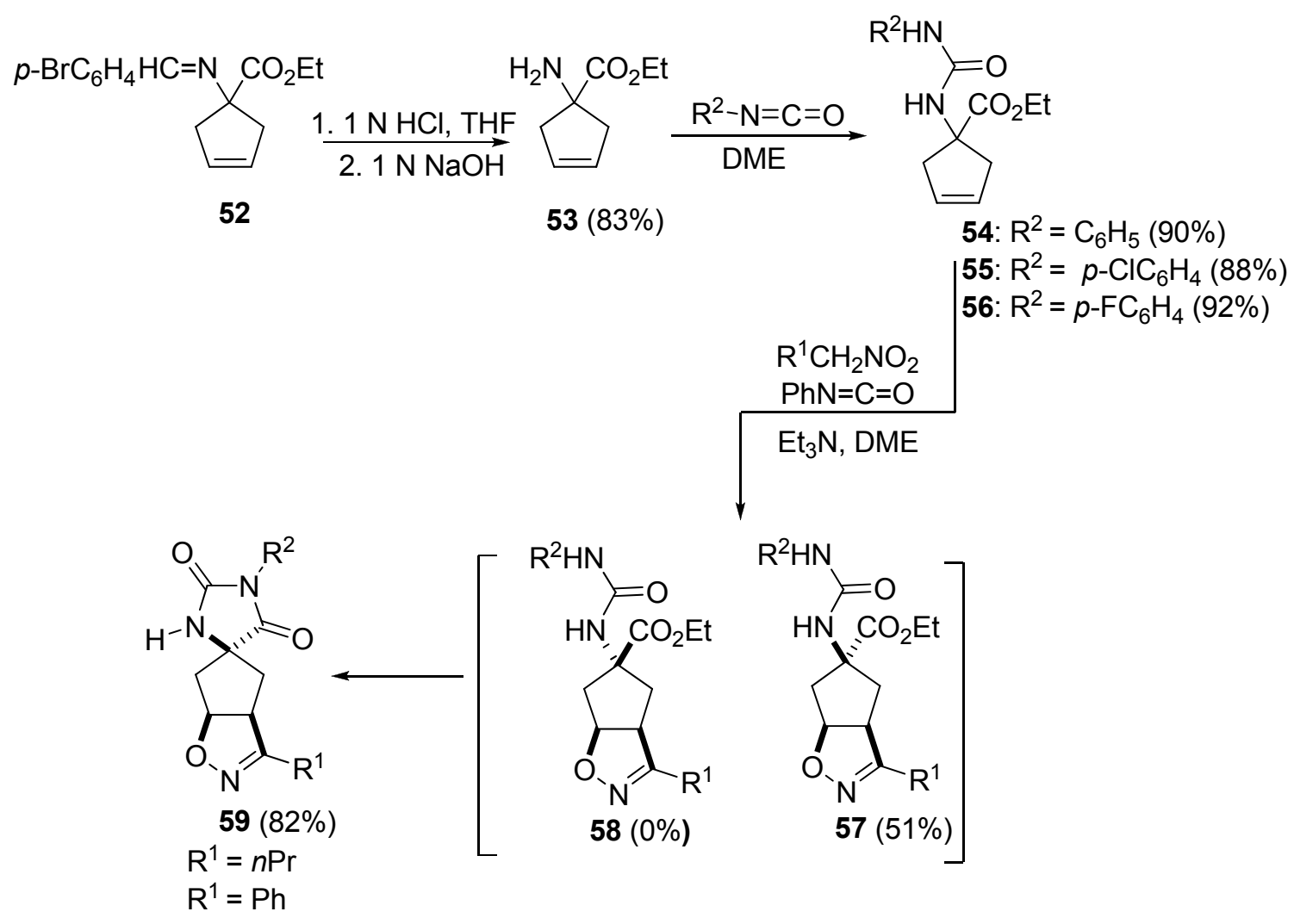

Scheme 21. Preparation of hydantoin-containing heterocycles 59.

In order to prepare hydantoin derivatives 59, the 1,3-cycloaddition of nitrile oxides to dipolarophiles 54-56 was performed. The nitrile oxides were generated by Mukaiyama's method from primary nitroalkanes in the presence of $\mathrm{Et}_{3} \mathrm{~N}$. The reactions gave only one cycloadduct 57, and cyclization to hydantoins 59 can be achieved without intermediate isolation.

The diastereoselective cycloaddition of cyclopentenyl ureas with nitrile oxides can be understood in terms of the on H-bonding-directing effect in the cycloaddition step (Figure 2). ${ }^{92}$

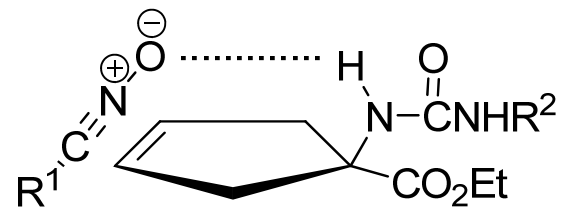

Figure 2. H-bonding-controlled cycloaddition. 
In view of the biological activities of the spirohydantoins and spiroisoxazolines, strategies were developed for the synthesis of hydantoin- and izoxasoline-containing heterocycles with a central cyclobutane core (Figure 3$).^{93}$

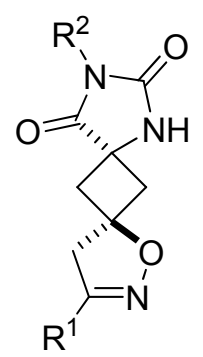

60

Figure 3. Spiroisoxazoline derivative 60.

For the generation of nitrile oxides, different aldoxime derivatives were used in the presence of bleach, in $\mathrm{CH}_{2} \mathrm{Cl}_{2}$ (Scheme 22).

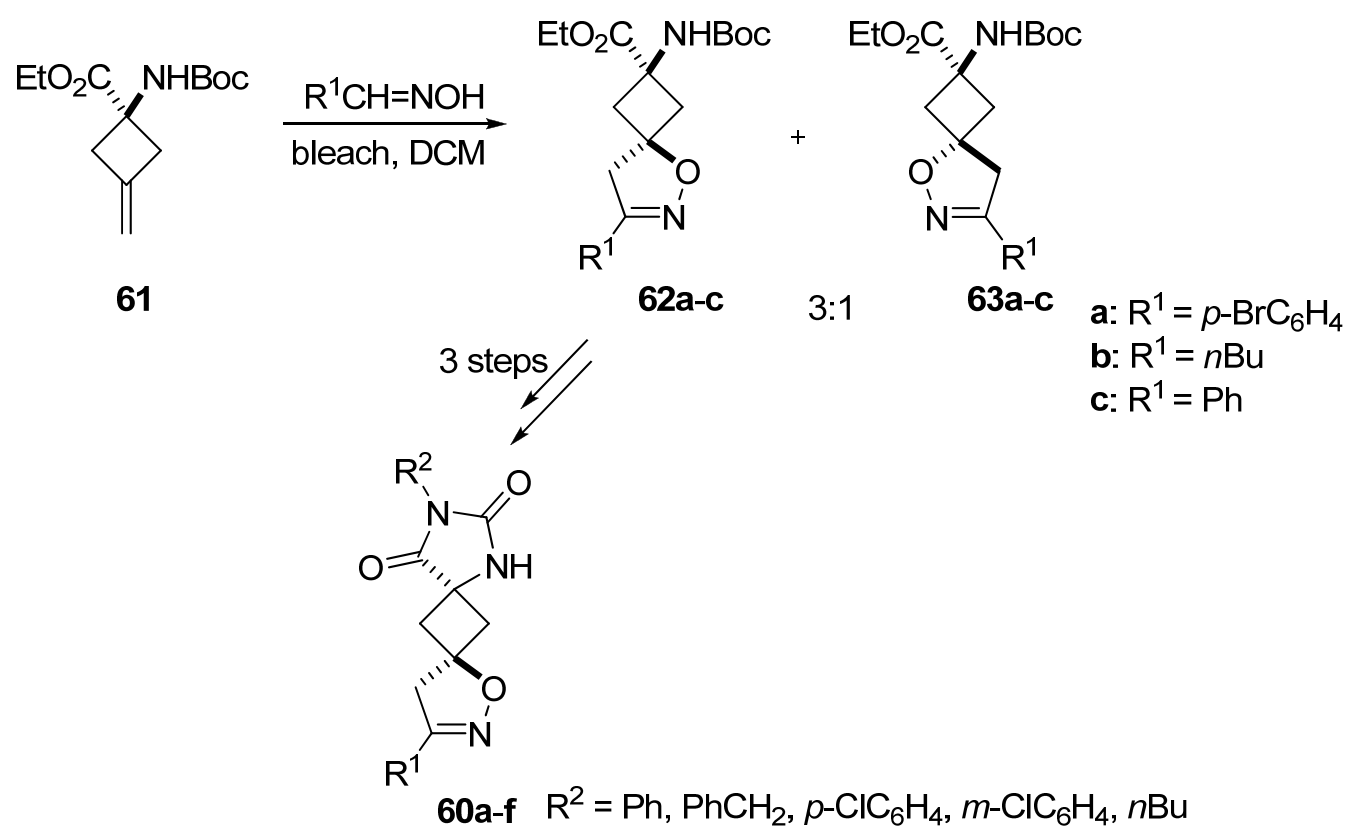

Scheme 22. Synthesis of hydantoin- and isoxazoline-containing derivatives from cyclic amino acids. 
The exo-methylene cyclobutane system induced some diastereoselectivity: the H-bond-directed product $\mathbf{6 2}$ was obtained with 3:1 selectivity relative to the non-H-bonddirected product 63. After the preparation of isoxazoline-containing derivatives 62a-c, neutralization with $\mathrm{Et}_{3} \mathrm{~N}$ afforded free amines, treatment of which with various isocyanates furnished the corresponding urea derivatives. Treatment of these urea derivatives with base afforded dispirocyclobutanoids $\mathbf{6 0} . .^{93}$

\subsection{Synthesis of highly functionalized bioactive amino acids by $1,3-$ dipolar cycloaddition of nitrile oxides as key step}

The influenza virus is one of the most dangerous known to humans. Over the past two decades, a number of classes of neuraminidase inhibitors have been developed and shown to be somewhat effective in controlling influenza infections in humans. ${ }^{94-101}$ Zanamivir (64) and Oseltamivir (65) ${ }^{96,98-101}$ (Figure 4) have been approved for the treatment and prevention of influenza. Both are effective inhibitors of the A and B forms of neuraminidase, but as a highly polar compound Zanamivir requires administration by oral inhalation, and Oseltamivir has been reported to cause nausea and vomiting. A more recent agent, Peramivir (66), ${ }^{97}$ has been shown to be a potent neuroaminidase inhibitor.
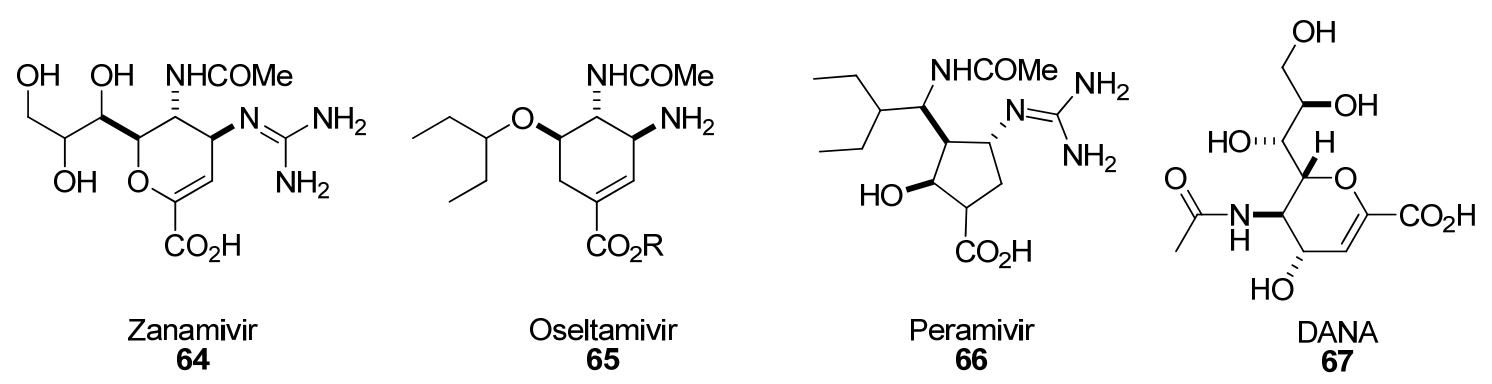

Figure 4. Structures of highly functionalized cyclic amino acid derivatives as neuraminidase inhibitors.

A number of other modified derivatives of Zanamivir, Oseltamivir and Peramivir are also potent neuroaminidase inhibitors. ${ }^{98}$ A number of publications have appeared from the 
Chand laboratories on neuroaminidase inhibitors, ${ }^{94,95,98 .}$ the aim being the synthesis of multisubstituted cyclopentane derivatives, analogues of Peramivir (Figure 5), which can serve as potential influenza neuroaminidase inhibitors. ${ }^{94,95}$

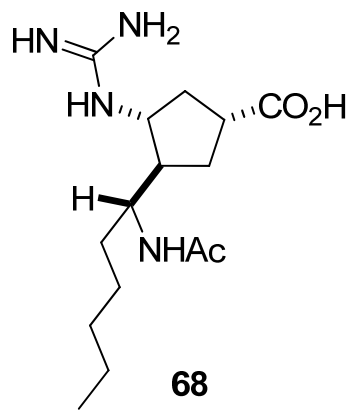

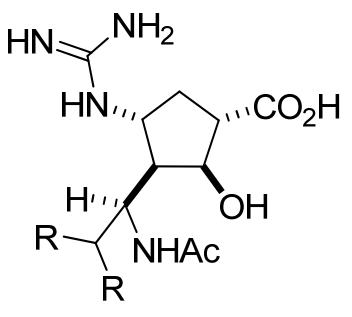

69a: $R=E t$ 69b: $\mathrm{R}=n \mathrm{Pr}$

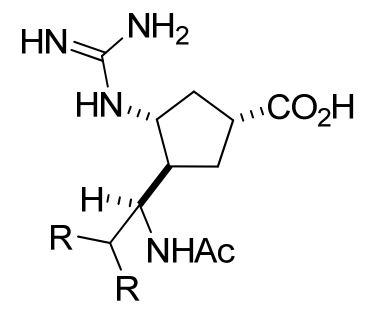

70a: $R=E t$ 70b: $\mathrm{R}=n \mathrm{Pr}$

Figure 5. Some Peramivir analogues.

The target molecule 68 was synthetized from 3-cyclopentene-1-carboxylate $71 .^{94}$ The 1,3-dipolar cycloaddition of $\mathbf{7 1}$ to valeronitrile oxide (generated in situ from $\mathrm{C}_{5} \mathrm{H}_{11} \mathrm{NO}_{2}$, $\mathrm{PhNCO}$ and $\mathrm{Et}_{3} \mathrm{~N}$ ) gave both isomers (72 and 73) in a ratio of 4:1 (Scheme 23). 


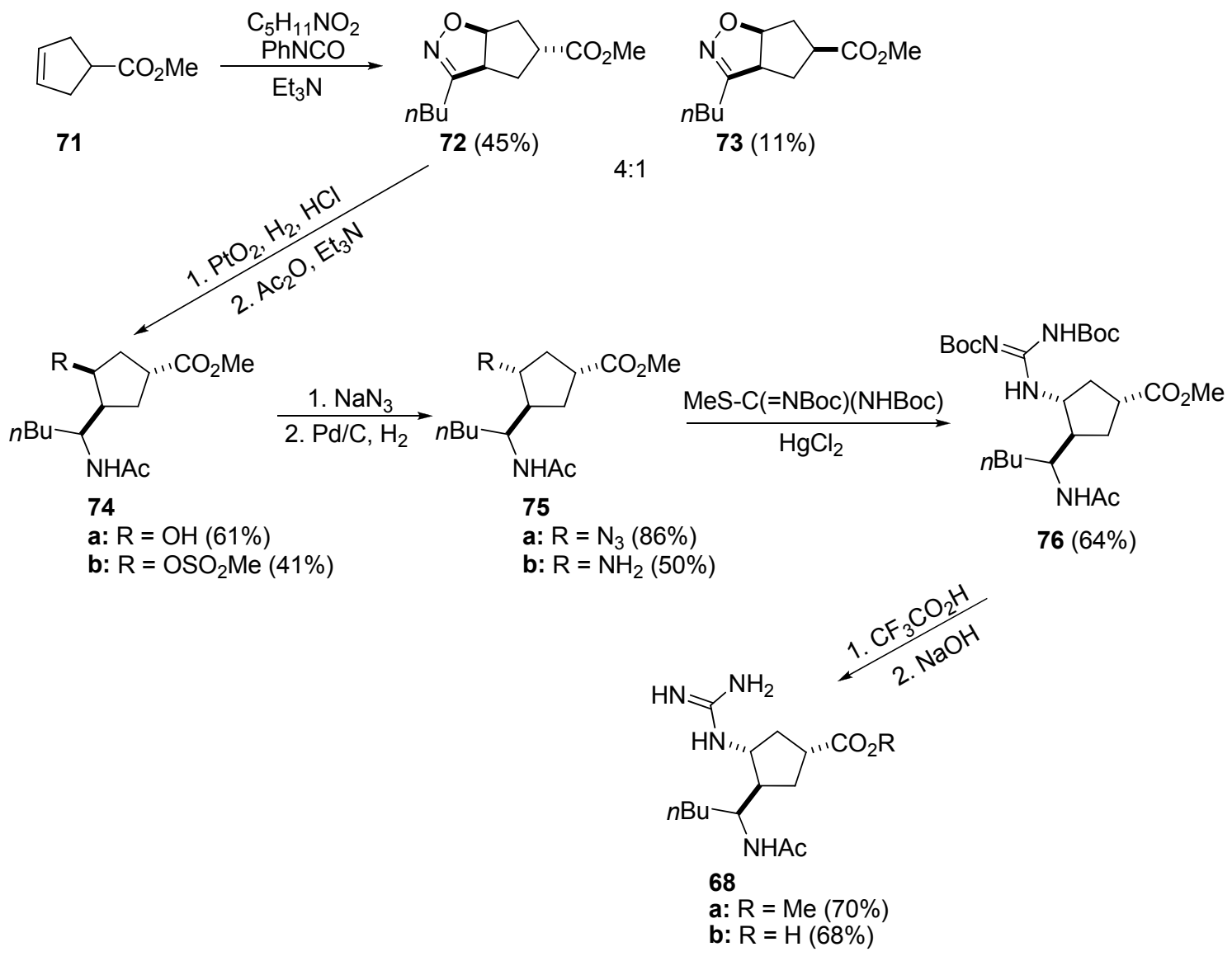

Scheme 23. Syntheses of multisubstituted cyclopentane derivatives.

Isoxazoline 72 was first reducted with $\mathrm{PtO}_{2} / \mathrm{H}_{2}$, and then acetylated to give 74a. Transformation of the hydroxy group to an azide or amino function afforded 75. 75b was converted to the target compound $\mathbf{6 8}$ via $\mathbf{7 6}$ by treatment with 1,3-bis(tert-butoxycarbonyl)-2-methyl-2-thiopseudourea.

In compound 72, the isoxazoline ring was fused with C-3 and C-4 with respect to the carboxyl function. A compound was planned with the isoxazoline ring fused with C-2 and $\mathrm{C}-3$. In this case, the hydroxy group would be attached to C-2; thus, an amino group is required at $\mathrm{C}-4$ on the cyclopentane ring for conversion into a guanidino group. Compounds 69a,b (Figure 5), with a double bond between $\mathrm{C}-2$ and $\mathrm{C}-3$, were subjected to nitrile oxide addition. $^{94}$ Cycloadduct $\mathbf{7 9}$ was prepared from the commercially available 2-azabicylco[2.2.1]hept-5-en-3-one 77 (Vince lactam), which was first transformed to protected amino ester 78. ${ }^{94,95}$ This compound underwent 1,3-dipolar cycloaddition with 
nitrile oxides (derived from 2-ethyl-1-nitrobutane or 2-propyl-1-bromopentane) to give four cycloadducts, 79a,b, 80a, 81a and 82a (Scheme 24). The main adduct, 79, was isolated by column chromatography in a yield of $60 \%$; the total yield of the other three isomers was $15 \%$.

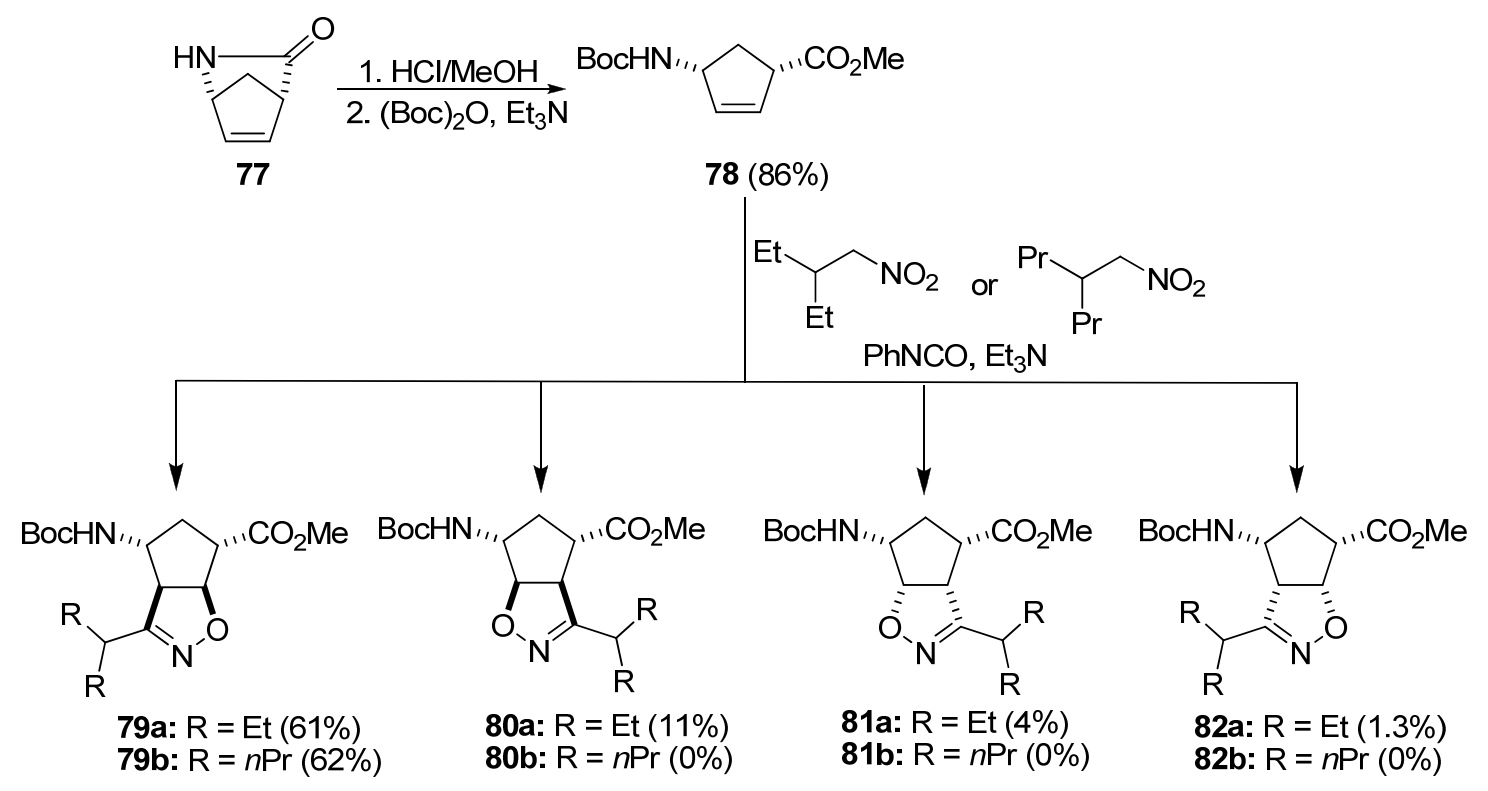

Scheme 24. Syntheses of isoxazoline-fused cyclic $\gamma$-amino acid derivatives 79-82.

In the major products $\mathbf{7 9 a}, \mathbf{b}$, the isoxazoline ring was opened by hydrogenolysis in $\mathrm{MeOH}$ in the presence of $\mathrm{PtO}_{2}$ and one equivalent of $\mathrm{HCl}$ to give 83a,b (Scheme 25). The desired target compounds (69a,b and 70a,b) were next prepared in 4 or 6 steps. 


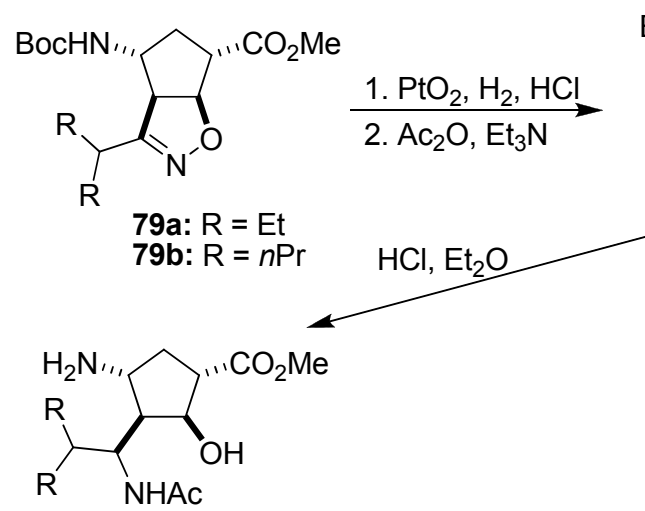

89a: $R=$ Et $(67 \%)$

89b: $\mathrm{R}=n \operatorname{Pr}(98 \%)$

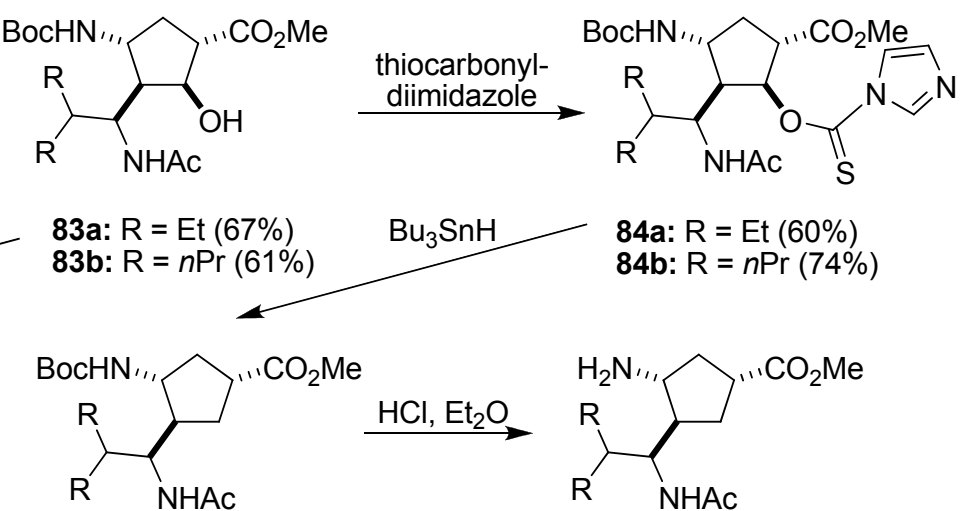

85a: $\mathrm{R}=\mathrm{Et}(95 \%)$

85b: $\mathrm{R}=n \operatorname{Pr}(91 \%)$

86a: $R=E t(100 \%)$

$\mathrm{H}_{3} \mathrm{CS}-\mathrm{C}(=\mathrm{NBoc})(\mathrm{NHBOC})$

86b: $\mathrm{R}=n \operatorname{Pr}(100 \%)$

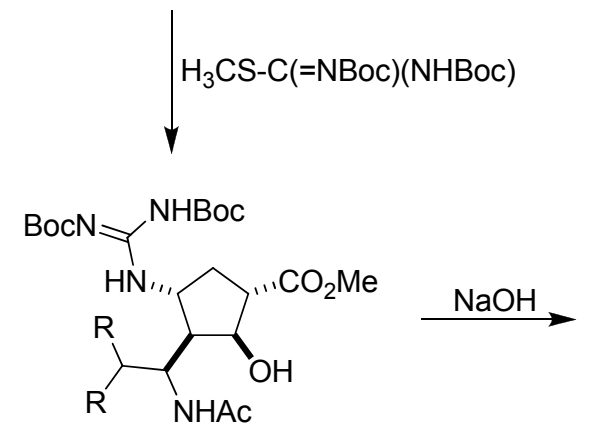

90a: $\mathrm{R}=\mathrm{Et}(74 \%)$

90b: $\mathrm{R}=n \operatorname{Pr}(72 \%)$

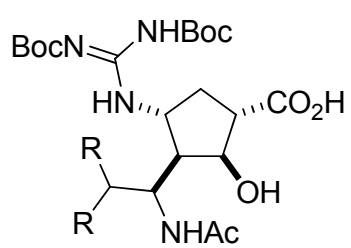

91a: $R=E t(90 \%)$

91b: $\mathrm{R}=n \operatorname{Pr}(91 \%)$

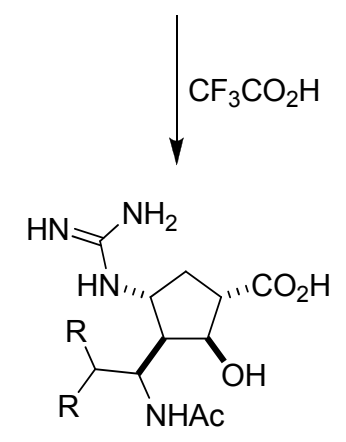

69a: $\mathrm{R}=\mathrm{Et}(68 \%)$

69b: $\mathrm{R}=n \operatorname{Pr}(28 \%)$

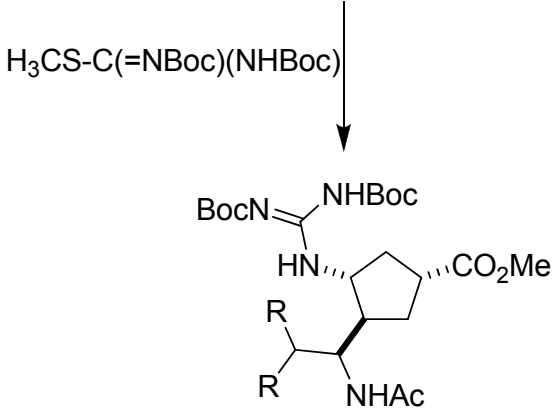

87a: $R=$ Et $(78 \%)$

87b: $\mathrm{R}=n \operatorname{Pr}(76 \%)$
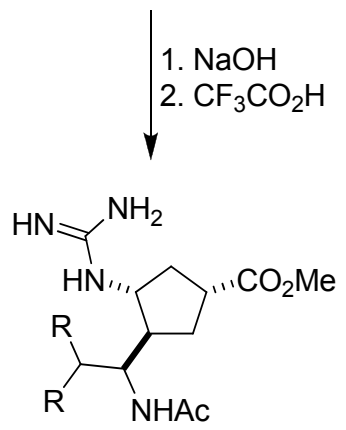

70a: $\mathrm{R}=\mathrm{Et}(78 \%)$ 70b: $\mathrm{R}=n \operatorname{Pr}(26 \%)$

Scheme 25. Syntheses of Peramivir analogues 69a,b and 70a,b.

Biological analysis revealed that structures such as $\mathbf{6 9 a}, \mathbf{b}$ and $\mathbf{7 0 a}, \mathbf{b}$ have similar or better efficacy in vivo in comparison with Zanamivir and Oseltamivir when administered orally or intranasally. These compounds are of great promise as potential drugs if administration routes other than oral are chosen, and prodrugs will be investigated. ${ }^{94,95}$ 


\section{RESULTS AND DISCUSSION}

\subsection{Synthesis of racemic and enantiomerically pure starting materials}

$\mathrm{C}$-C double bond-containing $\beta$-amino esters as dipolarophiles were prepared as starting materials for planned 1,3-dipolar cycloaddition with nitrile oxides. These $\beta$-amino ester carboxylates 94a-d were prepared by well-known methods, starting from cyclopentadiene and cyclohexadienes (92a-c) ${ }^{102,103}$ In the first step, bicyclic $\beta$-lactams 93a-c were synthetized by $\mathrm{N}$-chlorosulfonyl isocyanate (CSI) addition to dienes 92a-c (Scheme 26). The reactions were carried out at $0{ }^{\circ} \mathrm{C}$ in dry diethyl ether, the [2+2] cycloaddition resulting in the formation of the corresponding sulfonamide. The $\mathrm{SO}_{2} \mathrm{Cl}$ group was removed by hydrolysis with $\mathrm{Na}_{2} \mathrm{SO}_{3}$, which led to the desired $\beta$-lactams 93a-c. The products were purified by crystallization from diisopropyl ether.

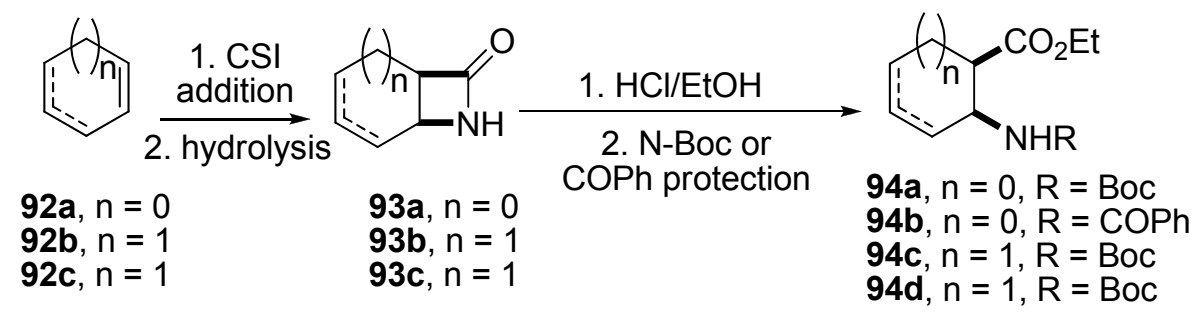

Scheme 26. Preparation of protected aminocyclopentane- or cyclohexane carboxylates

94a-d.

The lactam ring in azetidinones 93a-c was opened at $0{ }^{\circ} \mathrm{C}$ in dry EtOH with $\mathrm{HCl} / \mathrm{EtOH}$ solution. After $1 \mathrm{~h}$, the ester hydrochloride had crystallized out from the solution and the pure product was filtered off from the reaction mixture. Finally, the amino group was protected with the Boc or COPh protocol (Scheme 26). N-Boc protection was carried out with $\mathrm{Boc}_{2} \mathrm{O}$ in THF at $0{ }^{\circ} \mathrm{C}$ in the presence of $\mathrm{Et}_{3} \mathrm{~N}$, while $\mathrm{COPh}$ protection was achieved with benzoyl chloride in the presence of $\mathrm{NaHCO}_{3}$ in toluene, likewise at $0{ }^{\circ} \mathrm{C}$. The protected amino esters 94a-d were purified by crystallization from $n$-hexane.

Our research group has developed a method for translocation of the $\mathrm{C}-\mathrm{C}$ double bond in the carbocycle of the $\beta$-amino acid, starting from bicyclic $\beta$-lactam $\mathbf{9 3 b} .^{103}$ The reaction is 
based on regio- and stereoselective iodolactonization in the presence of $I_{2} / \mathrm{KI}$ (Scheme 27). The iodolactonization of cis and trans $\mathrm{N}$-protected $\beta$-amino acids 95 and 99 was performed in DCM at room temperature, in the presence of aqueous $\mathrm{NaHCO}_{3}$ solution. The reaction sequence was followed by dehydroiodination with 1,8-diazabicyclo[5.4.0]undec-7-ene in THF under reflux. The desired cis- and trans-lactones 96 and $\mathbf{1 0 0}$ were purified by crystallization from $n$-hexane.

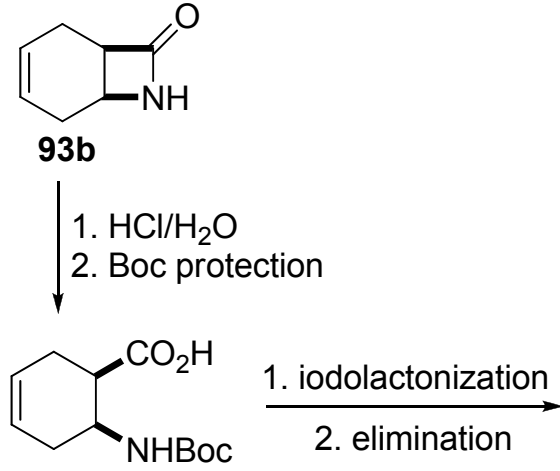

95

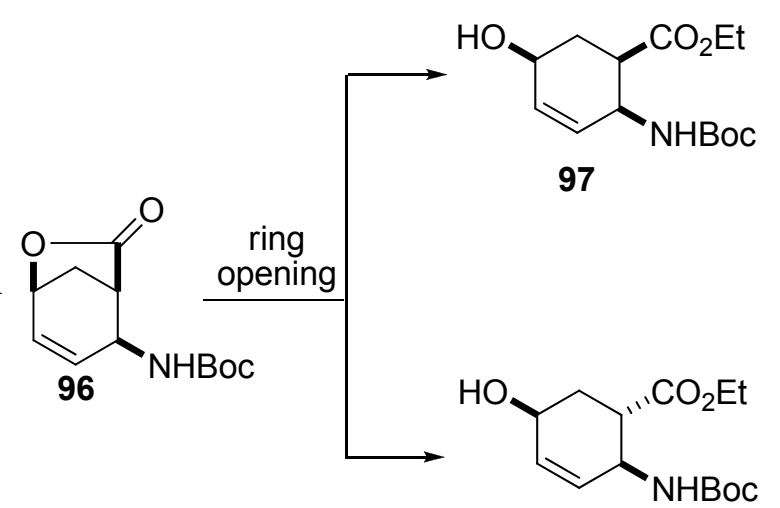

98

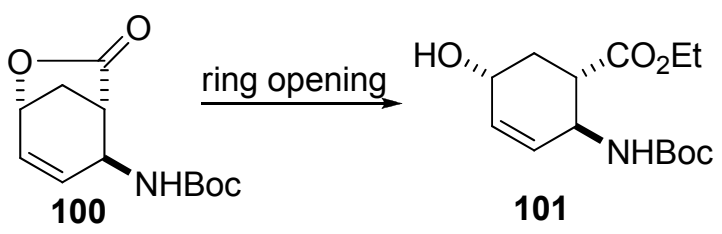

Scheme 27. Preparation of cis- and trans-lactones 96 and 100, and hydroxylated amino esters 97,98 and 101.

Lactone opening with $\mathrm{NaOEt}$ furnished three hydroxylated amino ester stereoisomers, 97, 98 and 101 (Scheme 27). ${ }^{103}$ Epimerization was also observed in the case of cis-lactone 96, because of the presence of base in the reaction mixture ( $\mathrm{NaOEt}$, see section 3.3). Stereoisomers 97 and 98 were separated and purified by column chromatography on silica gel, with $n$-hexane/EtOAc as eluent, while compound 101 was isolated by crystallization.

For the preparation of enantiomerically pure starting compound (+)-102 and (-)-93, racemic $\beta$-lactam 93a was subjected to enzymatic resolution. ${ }^{104}$ The protocol was based on the lipase-catalysed enantioselective ring opening of racemic $\beta$-lactam 93a. The 
commercially available CAL-B was used as enzyme. The reaction, carried out in $i \operatorname{Pr}_{2} \mathrm{O}$, afforded the desired amino acid enantiomer (+)-102 and the $\beta$-lactam (-)-93a enantiomer in excellent enantiomeric excess $\left(e e>99 \%\right.$, Scheme 28). ${ }^{105}$ Both enantiomers were then transformed to the required dipolarophiles, (+)-94a and (-)-94a, by esterification and N-Boc protection in the case of (+)-94a, and by azetidinone ring opening (-)-93a, followed by N-Boc protection (Scheme 28). ${ }^{106}$

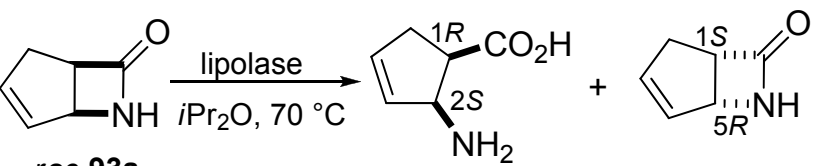

rac-93a

1. $\mathrm{SOCl}_{2} / \mathrm{EtOH}, 0{ }^{\circ} \mathrm{C}$ to $78{ }^{\circ} \mathrm{C}$

2. $\mathrm{Boc}_{2} \mathrm{O}, \mathrm{Et}_{3} \mathrm{~N}, \mathrm{THF}, \mathrm{O}^{\circ} \mathrm{C}$ to $20^{\circ} \mathrm{C}$

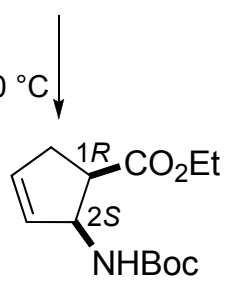

$(+)-94 a$
(+)-102
$(-)-93 a$

1. $\mathrm{HCl} / \mathrm{EtOH}, 0^{\circ} \mathrm{C}, 1 \mathrm{~h}$ 2. $\mathrm{Boc}_{2} \mathrm{O}, \mathrm{Et}_{3} \mathrm{~N}, \mathrm{THF}, 0^{\circ} \mathrm{C}$ to $20^{\circ} \mathrm{C}$

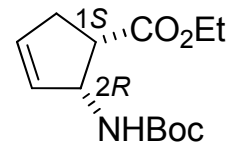

$(-)-94 a$

Scheme 28. Preparation of N-Boc-protected aminocyclopentene carboxylate enantiomers $(+)-94 \mathbf{a}$ and (-)-94a.

\subsection{Synthesis of isoxazoline-fused cispentacin and transpentacin derivatives}

For the synthesis of isoxazoline-fused cispentacin and transpentacin derivatives, the starting material used as dipolarophile was ethyl 2-aminocyclopentenecarboxylate $(\mathbf{9 4 a}, \mathbf{b})$ bearing different protecting groups, such as Boc or COPh moieties. The nitrile oxide as 1,3-dipolar agent for construction of the isoxazoline ring system was generated in situ from $\mathrm{EtNO}_{2}$ or $n \mathrm{PrNO}_{2}$ in the presence of $\mathrm{Boc}_{2} \mathrm{O}$ and DMAP, according to the methodology of Mukaiyama. The reactions were carried out in THF at room temperature, for $15 \mathrm{~h}$ (Scheme 29). Unfortunately, a significant amount of starting material was also detected by TLC monitoring, but this was recovered after purification by column chromatography on silica gel ( $n$-hexane/EtOAc). 


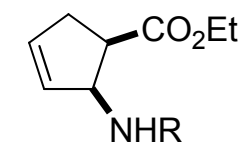

94a: $R=B o c$

94b: $\mathrm{R}=\mathrm{COPh}$

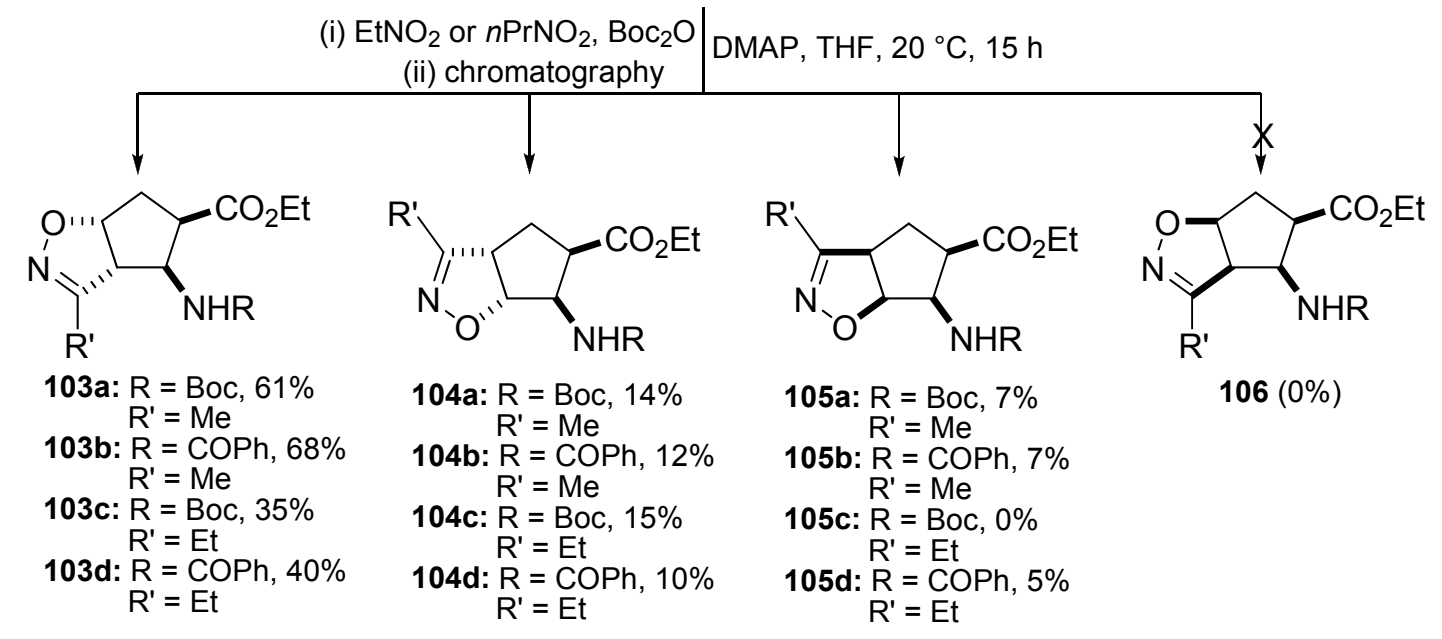

Scheme 29. Syntheses of isoxazoline-fused $\beta$-amino ester regio- and stereoisomers from cis2-aminocyclopentenecarboxylates 94a,b.

The cycloadditions resulted in three of the four possible regio- and stereoisomers, 103a-d, 104a-d and 105a-d, in a ratio of 70:20:10. Although the cycloaddition was not selective, three novel isoxazoline-fused cispentacin derivatives could be isolated and characterized.

When amino esters 94a,b underwent cycloaddition, $\mathrm{EtNO}_{2}$ being used for the generation of nitrile oxide, two trans- and one cis-isoxazoline-fused regio- and stereoisomers (103a,b, 104a,b and 105a,b) were obtained in good overall yield (82-87\%). The cycloadducts were separated and purified by column chromatography on silica gel ( $n$-hexane/EtOAc) instead of crystallization, since the latter proved difficult through the presence of the starting material and the three products. The structures of the products were confirmed by ${ }^{1} \mathrm{H}$ NMR, ${ }^{13} \mathrm{C}$ NMR and 2D NMR spectroscopic data (such as COSY, NOESY, HSQC and $\mathrm{HMBC}$ in DMSO or $\mathrm{CDCl}_{3}$ ), acquired with a 400 or $500 \mathrm{MHz}$ spectrometer. For determination of the regiochemistry, COSYand HSQC spectra were used. For the main product (103a,b), the $\mathrm{CH}_{2}$ group (H-6) from the cyclopentane skeleton gave a well-visible 
cross-peak with H-6a, which is next to the O-atom of the isoxazoline ring. This cross-peak was not found for the two minor products (104 and 105) (Figure 6).

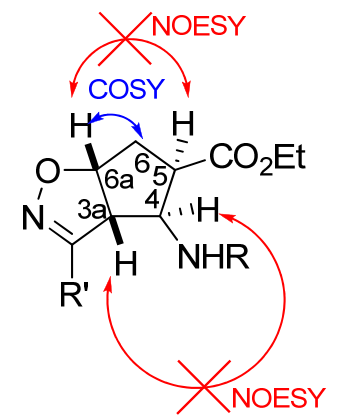

103

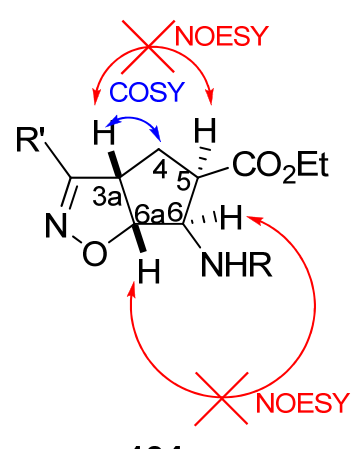

104

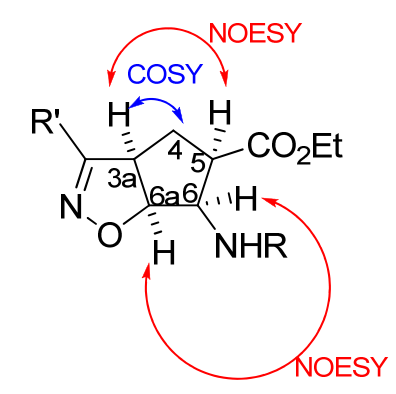

105

Figure 6. The visible cross-peaks in the COSY and NOESY spectra.

NOESY NMR spectroscopy was used to establish the stereochemistry of the cycloadducts. For the two regioisomers $(\mathbf{1 0 3 a}, \mathbf{b}$ and $\mathbf{1 0 4 a}, \mathbf{b})$, cross-peaks were not observed between H-6a and H-5, or H-3a and H-4, or between H-3a and H-5 or H-6a and H-6, and it may therefore be assumed that the isoxazoline ring is trans to the carbamate and ester functions. In contrast, the cross-peak was present for the very minor product, demonstrating that the ester and carbamate functions are cis to the isoxazoline ring. The structure of $\mathbf{1 0 3} \mathbf{b}$ was also determined by X-ray analysis (Figure 7).

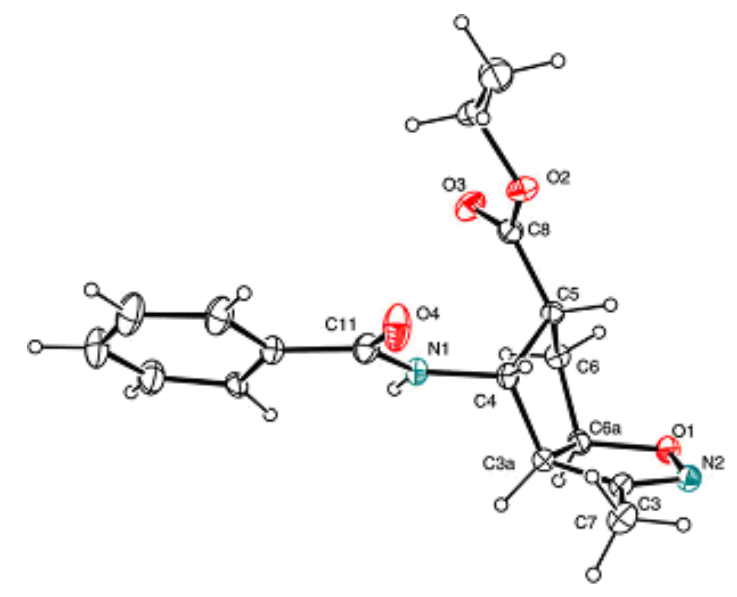

Figure 7. Ortep diagram of compound 103b.

The cycloadditions of nitrile oxides generated from $n \mathrm{PrNO}_{2}$ to Boc- or benzoylprotected ethyl 2-aminocyclopentencarboxylates (94a-b) were performed under similar 
conditions as described earlier for $\mathrm{EtNO}_{2}$. Similar results were obtained in these reactions too: three cycloadducts $(\mathbf{1 0 3 c}, \mathbf{d}, \mathbf{1 0 4 c}, \mathbf{d}$ and 105d) (Scheme 29, Figure 8) were detected and isolated in overall yields of $50-55 \%$. In the case of the Boc-protected amino ester carboxylate, the third cis-fused stereoisomer, 105c, could not be isolated (Scheme 29). For the separation of these products, column chromatography purification on silica gel ( $n$-hexane/EtOAc) was also used, and the unreacted starting material was recovered during the purification. The structures of the compounds were confirmed by ${ }^{1} \mathrm{H}$ NMR, ${ }^{13} \mathrm{C}$ NMR and the 2D techniques: COSY, NOESY, HSQC and HMBC. Visible cross-peaks in the COSY and NOESY spectra proved the structures of the cycloadducts. For compounds 103d and 104d, the X-ray diffraction data confirmed the structures (Figure 8).
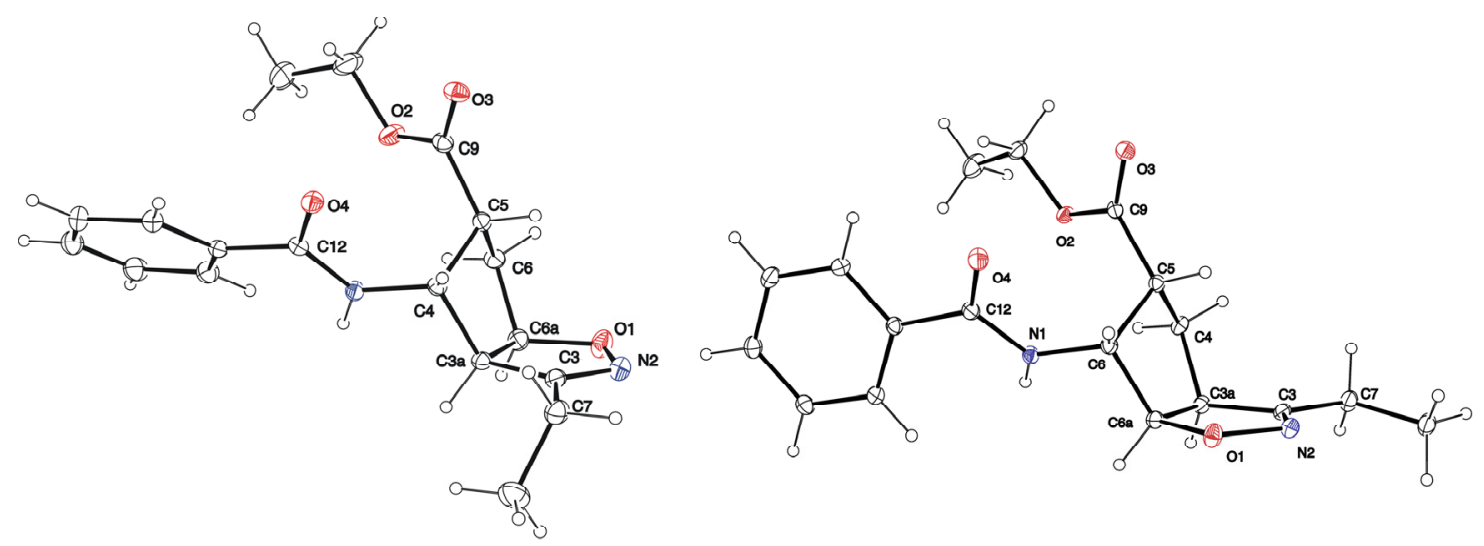

Figure 8. Ortep diagrams of compounds 103d and 104d.

In all cases, the "trans" isoxazoline derivatives 103a-d were formed as major products, with the $\mathrm{O}$-atom of the isoxazoline unit farther from the carbamate or amide group. The substituent on the nitrile oxide did not affect the selectivity of the cycloaddition dramatically, and we therefore continued an experimental search for synthetic routes with higher selectivity for the preparation of isoxazoline-fused cispentacins.

The dehydration of primary nitroalkanes to generate nitrile oxides may be attained not only with $\mathrm{Boc}_{2} \mathrm{O}$ and DMAP (Scheme 29), but also with PhNCO and $\mathrm{Et}_{3} \mathrm{~N}$. Compounds 94a,b were subjected to 1,3-dipolar cycloaddition under these conditions, using $\mathrm{RNO}_{2}$ $(\mathrm{R}=\mathrm{Me}$ or $\mathrm{Et}), \mathrm{PhNCO}$ and $\mathrm{Et}_{3} \mathrm{~N}$ in THF at $65^{\circ} \mathrm{C}$ for $15 \mathrm{~h}$ (Scheme 30$)$. 


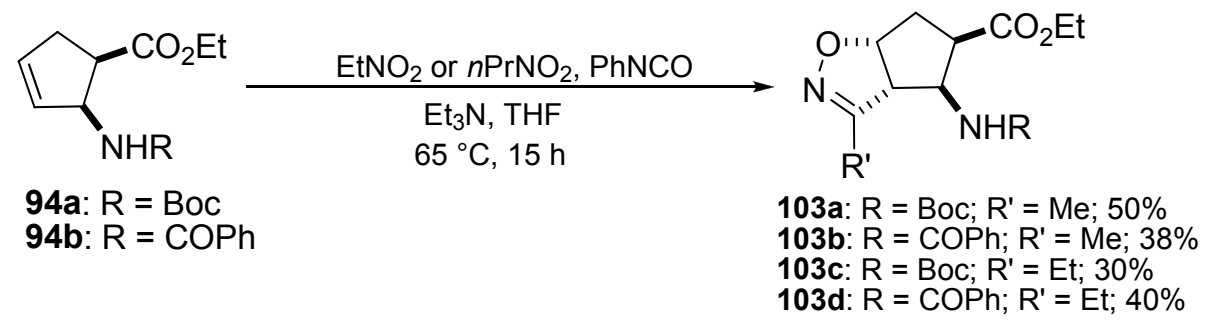

Scheme 30. Regio- and stereoselective syntheses of isoxazoline-fused $\beta$-amino esters 103a-d from ethyl cis-2-aminocyclopentenecarboxylates 94a,b.

The reactions resulted $100 \%$ selectively in 103a-d, which were isolated from the crude reaction mixture by column chromatography on silica gel ( $n$-hexane/EtOAc). Unfortunately, only low conversions were achieved and if the reaction time was prolonged, polymerization of the nitrile oxide was also observed. Besides the polymerization product, diphenylurea was detected, which was removed by filtration. In the products, the isoxazoline ring was trans to the carbamate and ester groups, and the O-atom of the isoxazoline skeleton was farther from the carbamate. The structure was confirmed by ${ }^{1} \mathrm{H} N M R,{ }^{13} \mathrm{C}$ NMR and $2 \mathrm{D}$ spectroscopicy. The explanation of the unexpected selectivity under these reaction conditions is not yet clear. The mechanism of the generation of nitrile oxide with $\mathrm{PhNCO}$ and $\mathrm{Et}_{3} \mathrm{~N}$ is similar to that for $\mathrm{Boc}_{2} \mathrm{O}$ and DMAP (see Scheme 5). We are not aware of any similar example in the literature.

The results of nitrile oxide cycloaddition to ethyl trans-2-aminocyclopentenecarboxylates 107a,b proved interesting (Scheme 31). Whereas the addition of nitrile oxide to the corresponding cis isomers 94a,b gave three cycloadduct isomers, 103a-d, 104a-d and 105a-d (Scheme 29), under the same experimental conditions $\left(\mathrm{RNO}_{2}, \mathrm{Boc}_{2} \mathrm{O}\right.$ and DMAP) the trans counterparts $\mathbf{1 0 7 a}, \mathbf{b} \quad 100 \%$ selectively furnished only one isoxazoline-fused cycloadduct isomer, 108a-d (Scheme 31). The structures of the new products were proved not only by means of the spectroscopic data, but also experimentally. We presumed that the cycloadduct formed is one of the diastereomers of the earlier-prepared cycloadduct (see Scheme 29), which can be synthetized by epimerization at C-5 in the presence of NaOEt in EtOH (see section 3.3). This expectation proved successful, for compounds 108a-d could also be prepared by epimerization of the very minor products 105a,b (Scheme 31) of cycloaddition to $\mathbf{9 4 a}, \mathbf{b}$. 


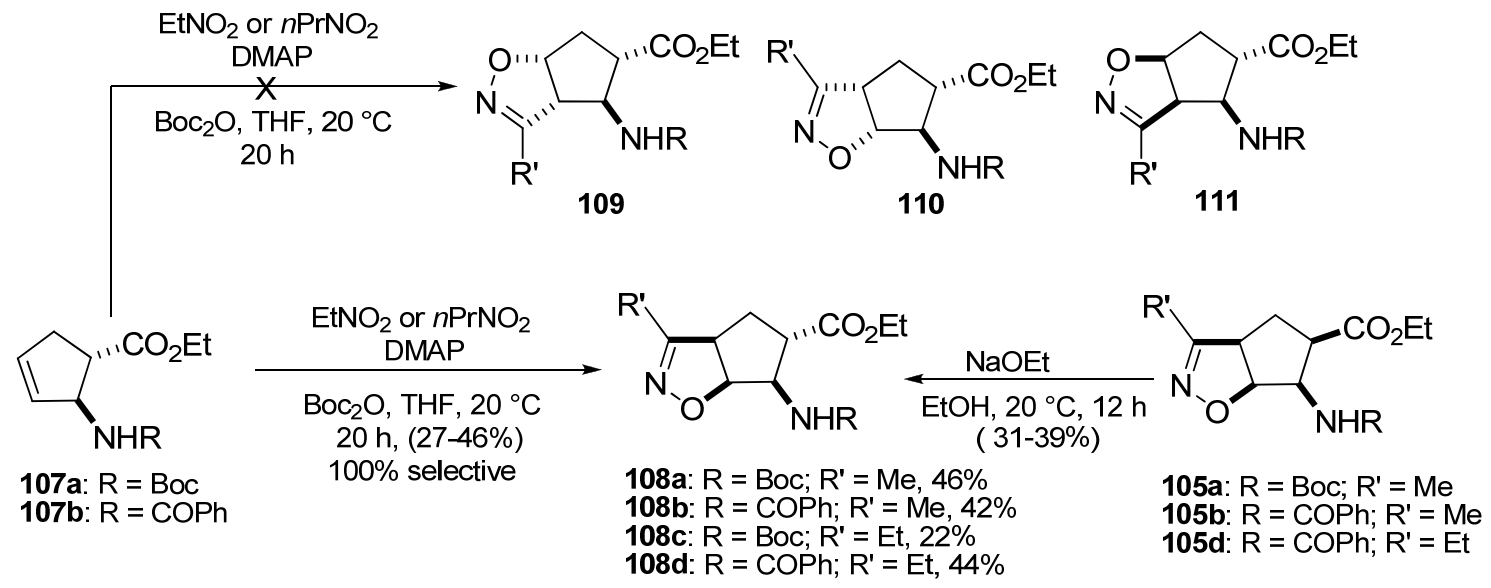

Scheme 31. Regio- and stereoselective syntheses of isoxazoline-fused $\beta$-amino esters 108a-d from trans-2-aminocyclopentenecarboxylates $\mathbf{1 0 7 a}, \mathbf{b}$.

Since both $\mathrm{Boc}_{2} \mathrm{O}$ and $\mathrm{PhNCO}$ in combination with $\mathrm{RNO}_{2}$ reacted with the protected cis amino ester 94a,b $100 \%$ regio- and stereoselectively, it appeared interesting to vary the substrate too. Accordingly, the Boc-diprotected cis amino ester 112 was reacted with nitrile oxide under the conditions given in Scheme 29. This transformation led selectively only to the "trans" isoxazoline-fused derivatives 113a,b (Scheme 32), in which the O-atom of the isoxazoline is farther from the carbamate. The product was readily separated from the unreacted starting material by column chromatography, with $n$-hexane/EtOAc as eluent. Unfortunately, the isolated yields were quite low (113a: 18\%, 113b: 15\%), a large quantity of starting material 112 being recovered during purification.

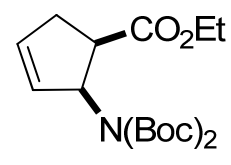

112

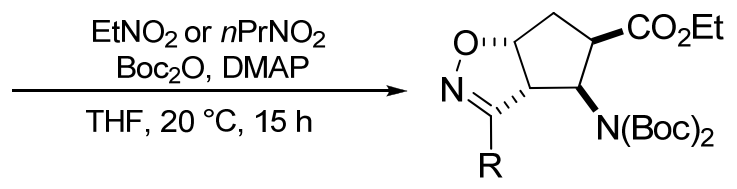

113a: $R=M e ; 18 \%$ 113b: $R=E t ; 15 \%$

Scheme 32. Regio- and stereoselective syntheses of isoxazoline-fused $\beta$-amino esters 113a,b from 112.

To confirm that the dipolarophile may affect the selectivity of the 1,3-dipolar cycloaddition of the nitrile oxide, ethyl 2-(tert-butoxycarbonylamino)cyclohex-3- 
enecarboxylate (114) and its regioisomer ethyl 2-(tert-butoxycarbonylamino)cyclohex-4enecarboxylate (116) were next used as dipolarophiles in the cycloaddition (Scheme 33).

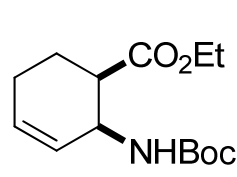

114

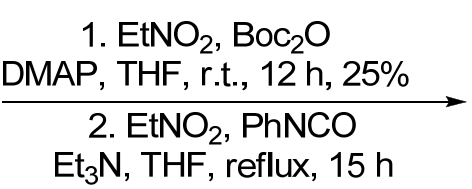

$\mathrm{Et}_{3} \mathrm{~N}, \mathrm{THF}$, reflux, $15 \mathrm{~h}$

$$
\text { 1. } \mathrm{EtNO}_{2}, \mathrm{Boc}_{2} \mathrm{O}
$$

DMAP, THF, r.t., $12 \mathrm{~h} \leadsto$ no transformation

$\mathrm{Et}_{3} \mathrm{~N}, \mathrm{THF}$, reflux, $15 \mathrm{~h}$

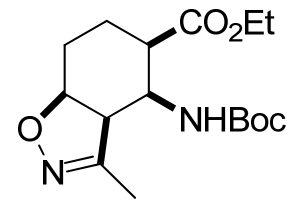

$115,23 \%$

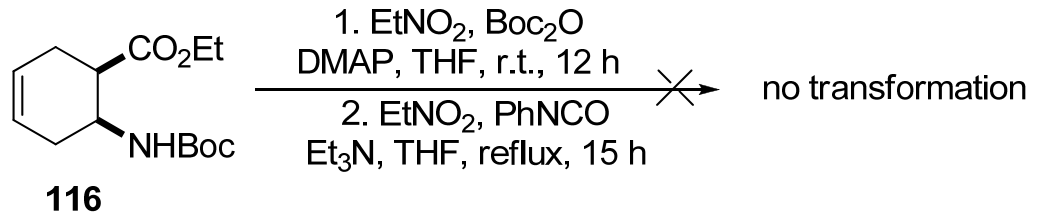

Scheme 33. Cycloaddition of the nitrile oxide to aminocyclohexenecarboxylates 114 and 116.

In the case of amino ester 114 both the $\mathrm{EtNO}_{2}$ and $\mathrm{PhNCO}$ and the $\mathrm{EtNO}_{2}$ and $\mathrm{Boc}_{2} \mathrm{O}$ systems were used as dehydrating agents for the generation of nitrile oxide. The reactions were carried out in THF solution for $15 \mathrm{~h}$. The crude product was purified by column chromatography on silica gel ( $n$-hexane/EtOAc) and the cycloaddition $100 \%$ selectively gave only one cycloadduct, 115. The structure of the product was identified via the ${ }^{1} \mathrm{H}$ NMR, ${ }^{13} \mathrm{C}$ NMR and 2D spectra (COSY, NOESY, HSQC and HMBC), which clearly confirmed that the isoxazoline ring is cis to the ester and amide functions and the O-atom of the isoxazoline ring is farther from the carbamate. Unfortunately, the yield of the reaction was low, and a large quantity of starting material was recovered during purification. The dipolarophile 116 proved inactive in the 1,3-dipolar cycloaddition, probably because the C-C double bond is distant and more isolated from the carbamate and ester functions.

Next, hydroxylated aminocarboxylates 97 and 98 (for the preparations, see Scheme 29) were subjected to the 1,3-dipolar cycloaddition of nitrile oxide through their olefinic bond. Although the reaction was attempted under different conditions, such as the Huisgen (from aldoximes) and Mukayama (from primary nitroalkanes) methodologies in different solvents, the required cycloadduct could not be prepared: only the starting material was detected on TLC. The reason for this is probably the reduced reactivity of the isolated ring double bond in 97 and 98 (Scheme 34). 
Further, in order to investigate the possibility of the preparation of novel isoxazolinefused cycloadducts, unsaturated cis-lactone 96, derived from azetidinone 93b (Scheme 27), was subjected to nitrile oxide cycloaddition. The nitrile oxide was generated from the reaction of $\mathrm{EtNO}_{2}, \mathrm{Boc}_{2} \mathrm{O}$ and DMAP in THF for $48 \mathrm{~h}$ at room temperature. Addition to 96 (Figure 9) furnished isoxazoline-fused aminolactone 117 regio- and stereoselectively, as the sole cycloaddition product, which was isolated from the crude reaction mixture by column chromatography on silica gel, using $n$-hexane/EtOAc as eluent (Scheme 34).

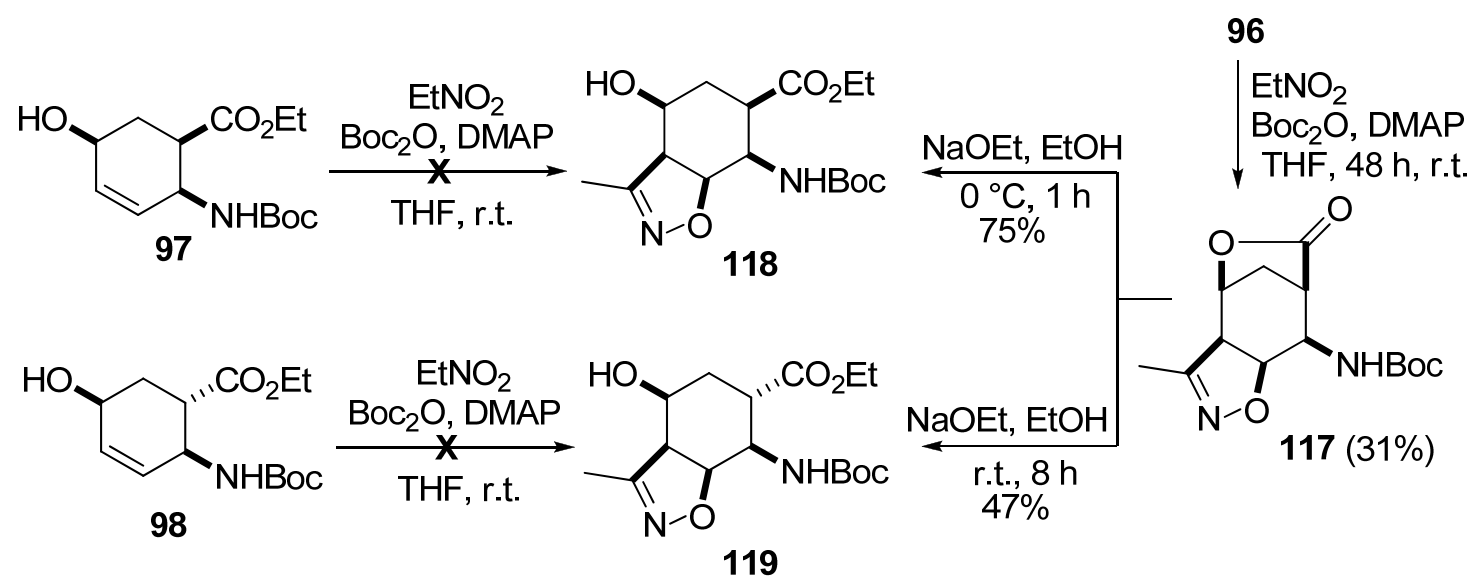

Scheme 34. Syntheses of isoxazoline-fused $\beta$-amino carboxylates 118 and 119.

In the cycloadduct, the isoxazoline ring and the carbamate group display cis relative stereochemistry, while the $\mathrm{O}$-atom of the isoxazoline ring is closest to the carbamate (Scheme 34). This stereochemistry was determined from the 2D NMR spectroscopic data. $\mathrm{PhNCO}$ was not used for the generation of nitrile oxide because a large amount of diphenylurea is formed during the cycloaddition, and 100\% selectivity was achieved with $\mathrm{Boc}_{2} \mathrm{O}$ as dehydrating agent.

Next, compound 117 was subjected to lactone opening with NaOEt. The reaction at 0 ${ }^{\circ} \mathrm{C}$ in EtOH for $1 \mathrm{~h}$ afforded hydroxylated isoxazoline-fused aminocyclohexanecarboxylate 118 in a yield of $75 \%$ (Scheme 34 ). The product was crystallized from $n$-hexane/EtOAc. Lactone opening with NaOEt at $20{ }^{\circ} \mathrm{C}$ for $8 \mathrm{~h}$ involved epimerization at C-8 to give a hydroxylated amino ester 119, a diastereoisomer of 118, in a yield of 47\% (Scheme 34). This rather modest yield is probably a result of the formation of various polymer materials. 


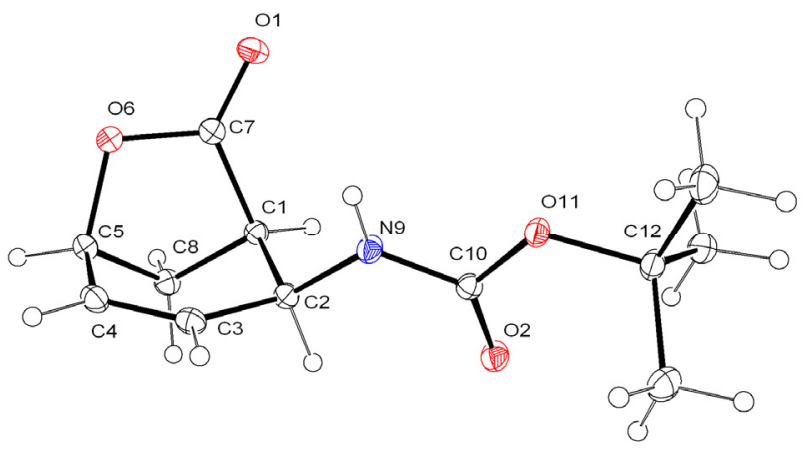

Figure 9. Ortep structure of 96.

The reason why isoxazolines $\mathbf{1 1 8}$ and $\mathbf{1 1 9}$ could not be prepared by the addition of nitrile oxide to the C-C double bond of hydroxylated amino ester 97 or 98 (Figure 10) is unclear. The explanation of the unexpected difference in the reactivity of bicyclic lactone 96 (Figure 9) and hydroxylated esters 97 and $\mathbf{9 8}$ in nitrile oxide dipolar cycloadditions is not yet known. We postulated that it is related to the length of the $\mathrm{C}-\mathrm{C}$ double bond in their structures.
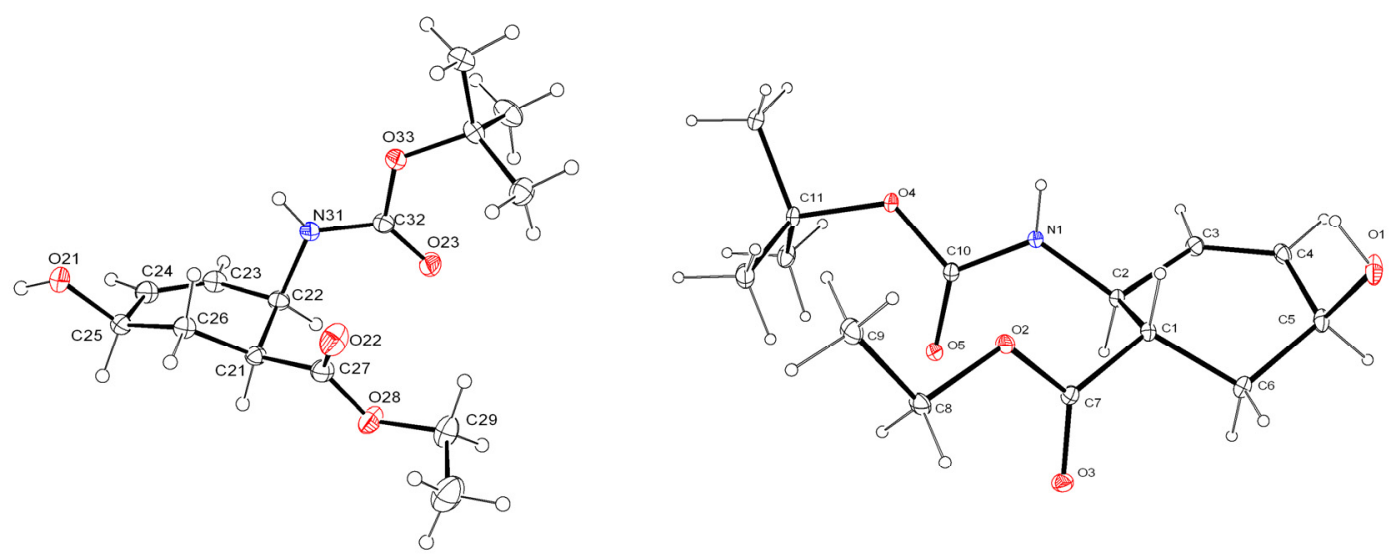

Figure 10. Ortep structures of 97 and 98.

We initially presumed that in consequence of the rigidity in the structure of lactone 96, the $\mathrm{C} 3-\mathrm{C} 4 \quad(\mathrm{C}=\mathrm{C})$ distance is higher in comparison with the $\mathrm{C} 3-\mathrm{C} 4$ (C23-C24 in Ortep, Figure 10) distance in 97, and C3-C4 in 98. Unfortunately, X-ray studies did not support this assumption. The C-C double bond distance measured in 96 was $1.323 \AA$, 
while that in 97 was $1.325 \AA$, i.e. there was no relevant difference in length. However, the difference in the reactivity of the $\mathrm{C}-\mathrm{C}$ double bond in these two types of molecules may be attributed to stereochemical reasons: our experimental results indicate that the rigid ring framework in 96 determines the much higher reactivity of its olefinic bond, in contrast with the $\mathrm{C}-\mathrm{C}$ double bond in $\mathbf{9 7}$ or $\mathbf{9 8}$, which do not contain constrained systems.

Following similar experiments, other novel highly-substituted $\beta$-aminocyclohexanecarboxylates were prepared by 1,3-dipolar cycloaddition of nitrile oxides to trans-lactone 100. ${ }^{103}$ Again, the cycloaddition to hydroxylated ester $\mathbf{1 0 1}$ failed, leading to no isoxazoline-fused products; only the presence of starting material was found on TLC. The addition of nitrile oxide (derived $\mathrm{EtNO}_{2}, \mathrm{Boc}_{2} \mathrm{O}$ and DMAP in THF) to lactone 100 was then effected (Scheme 35). The reaction resulted 100\% regio- and stereoselectively in isoxazoline derivative 120, which was isolated by column chromatography on silica gel ( $n$-hexane/EtOAc). In this product, as a result of the H-bonding interaction, the isoxazoline ring is cis to the carbamate, while the O-atom of the heterocycle is closest to this group (NHBoc). This finding was confirmed by the 2D spectroscopic data.

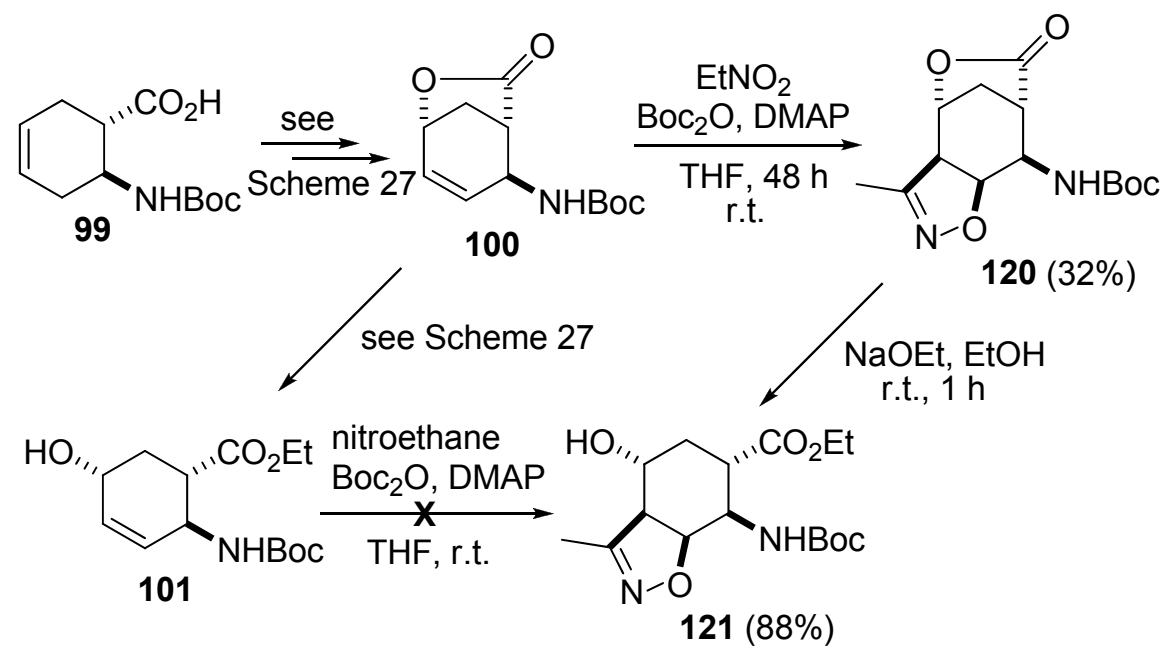

Scheme 35. Synthesis of isoxazoline-fused $\beta$-aminocarboxylate 121.

On treatment with NaOEt at room temperature for $1 \mathrm{~h}, \mathbf{1 2 0}$ underwent lactone ring opening to result in the corresponding hydroxylated ester 121, which was purified by crystallization from an $n$-hexane/EtOAc solvent system. 


\subsection{Regio- and stereoselectivity of 1,3-dipolar cycloaddition to protected cis-and trans-amino ester carboxylates}

In order to support our experimental results regarding the regio- and stereoselectivity of the 1,3-dipolar cycloaddition of nitrile oxides, theoretical calculations were made. 1,3-Dipolar cycloaddition to protected cis-2-aminocyclopent-3-enecarboxylates (94a,b) resulted in three cycloadducts, 103a-105d (Scheme 29), whereas with PhNCO as dehydrating agent only one cycloadduct was detected, 103a-d (Scheme 30). In all cases, the main product was the compound in which the carbamate and ester groups on the isoxazoline ring are in the trans arrangement, and the $\mathrm{O}$-atom of the isoxazoline skeleton is farthest from the carbamate. The regioselectivity can probably be explained in terms of electronic factors: because of the electron-withdrawing effect of the $\mathrm{N}$-atom of the carbamate, the negatively charged $\mathrm{O}$-atom of the dipolar agent attacks at C-4 of amino ester 94a,, $\mathbf{b}$, farthest from the carbamate or amide group. Similar regioselectivities were observed earlier in the reactions of nitrile oxides with $\gamma$-aminocarboxylates with a cyclopentene skeleton $^{94,95,97}$, though the selectivity of the cycloaddition was not analysed. These two reactions differ (see Schemes 29 and 30) only in the dehydrating agent, and we are not aware of any similar example in the literature. DFT calculations ${ }^{107}$ were carried out on the reaction of 94 and MeNCO by using the $\mathrm{G} 03^{108}$ program; the reaction enthalpies and Gibbs free energies of the transition states $\left(\Delta H^{\star}\right.$ and $\left.\Delta G^{\ddagger}\right)$ and products $(\Delta H$ and $\Delta G)$ are listed in Table 1.

Table 1. Enthalpies (in $\mathrm{kJ} \mathrm{mol}^{-1}$ ) and Gibbs free energies (in $\mathrm{kJ} \mathrm{mol}^{-1}$ ) of the transformations of $1 \mathbf{b}$ to $103 \mathbf{b}-106 \mathbf{b}$ in vacuo, with the implicit solvent and the explicit solvent model

\begin{tabular}{|l|l|l|l|l|l|l|l|l|l|l|l|l|}
\hline & \multicolumn{4}{|c|}{ in vacuo } & \multicolumn{3}{c|}{ in implicit solvent (THF) } & \multicolumn{3}{c|}{ with explicit co-solvent } \\
\hline & $\Delta H^{\ddagger}$ & $\Delta G^{\ddagger}$ & $\Delta H$ & $\Delta G$ & $\Delta H^{\ddagger}$ & $\Delta G^{\ddagger}$ & $\Delta H$ & $\Delta G$ & $\Delta H^{\ddagger}$ & $\Delta G^{\ddagger}$ & $\Delta H$ & $\Delta G$ \\
\hline 103b & 55.8 & 114.1 & -169.5 & -104.3 & 59.1 & 118.2 & -165.7 & -100.0 & 67.3 & 126.1 & -164.1 & -100.1 \\
\hline 104b & 75.1 & 128.3 & -159.1 & -97.2 & 79.3 & 132.5 & -154.1 & -92.0 & 70.1 & 129.3 & -153.4 & -92.0 \\
\hline $\mathbf{1 0 5 b}$ & 49.8 & 109.5 & -164.1 & -101.5 & 54.2 & 113.8 & -160.3 & -98.1 & 75.8 & 135.5 & -160.2 & -97.7 \\
\hline $\mathbf{1 0 6 b}$ & 54.9 & 113.7 & -166.7 & -100.9 & 58.2 & 117.9 & -161.9 & -96.3 & 95.4 & 153.9 & -161.3 & -96.5 \\
\hline
\end{tabular}

Surprisingly, from a kinetic aspect, $\mathbf{1 0 5 b}$ was predicted to be the main product of the reaction, due to its lowest activation Gibbs free energy $\left(\Delta G^{\ddagger}\right)$. Compounds $\mathbf{1 0 3 b}$ and 106b exhibited practically equal $\Delta G^{\ddagger}$ values, but the significantly higher energies (ca. $4 \mathrm{~kJ} \mathrm{~mol}^{-1}$ ) suggest predicted concentrations of only a few per cent. The formation of 
104b is least favourable. A possible explanation of the lowest-energy transition state of $\mathbf{1 0 5 b}$ is an intermolecular H-bond between MeNCO and the amide in 94b. The same results were obtained at each level of computation [HF/3-21G, B3LYP/6-31G(d,p) and B3LYP/6$311++\mathrm{G}(2 \mathrm{~d}, 2 \mathrm{p})]$, irrespective of the solvent model applied [IEFPCM(THF)]. It was earlier demonstrated that an explicit consideration of some selected solvent molecules or other components in the solvent provided a much more accurate picture of the mechanism. ${ }^{109}$ However, an $\mathrm{EtNO}_{2}$ excess can be regarded as a co-solvent, strongly H-bonded to the amide in $\mathbf{9 4 b}$. The lowest $\Delta G^{\ddagger}$ was computed for $\mathbf{1 0 3 b}$ (Figure 11), but the value for $\mathbf{1 0 4 b}$ was very close, in agreement with experiment, where $\mathbf{1 0 4 b}$ was also detected in a significant amount beside the main component $103 \mathrm{~b}$. For $105 \mathrm{~b}$ and $\mathbf{1 0 6 b}$, the $\Delta G^{\ddagger}$ values were in all cases higher than those calculated in vacuo, because the nitro compound occupied the reactive zone to some extent and hindered the attack of MeNCO (Figure 11).

\section{in vacuo or implicit solvent model:}
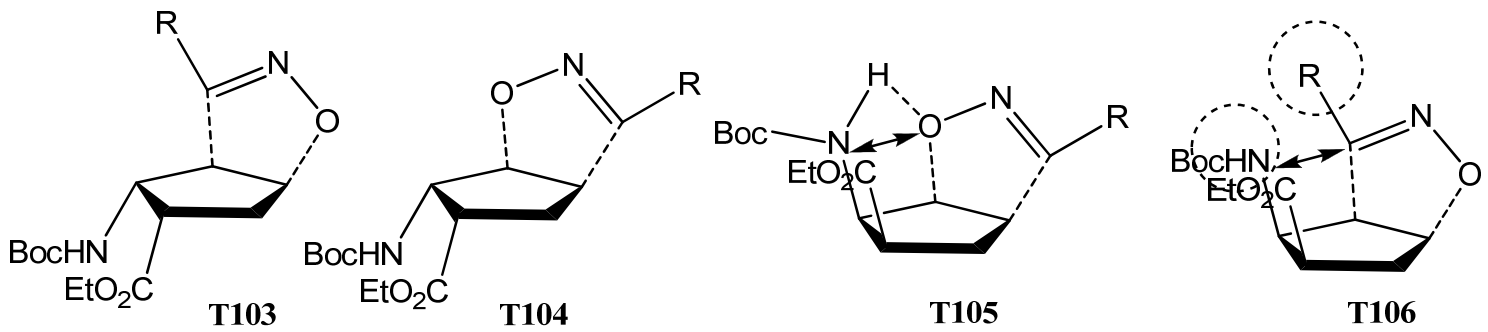

explicit solvent model:

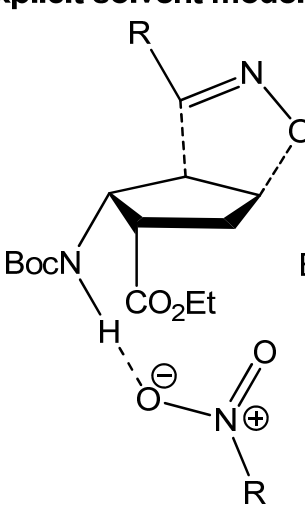

T103'

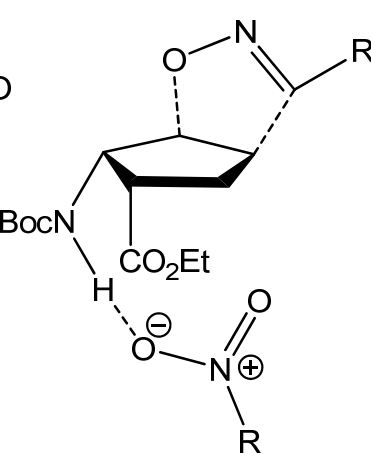

T104'

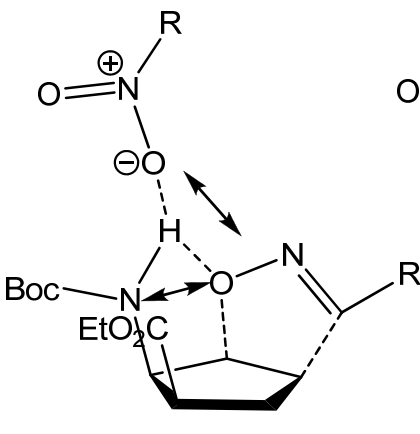

T105'

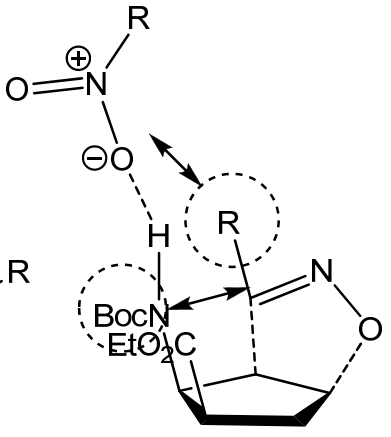

T106'

Figure 11. Transition states T103, T104 and T105 in the formation of cycloadducts 103-106; steric repulsions between $\mathrm{CO}_{2}$ Et and the nitrile oxides in $\mathrm{T} 103$ and T104, and between $\mathrm{NHBoc}$ and the nitrile oxide and $\mathrm{CO}_{2} \mathrm{Et}$ and the nitrile oxide in T106, and

H-bonding interaction between NHBoc and the nitrile oxide in T105. 
The selectivity of formation of $\mathbf{1 0 8 a - d}$ from $\mathbf{1 0 7 a}, \mathbf{b}$ is probably explained by: steric and $\mathrm{H}$-bonding interactions, as presented in Figure 12, i.e steric repulsion in the transition state (T108) between the nitrile oxide and the ester group and a H-bonding interaction between the carbamate and the nitrile oxide (Scheme 31, Figure 12). ${ }^{87}$

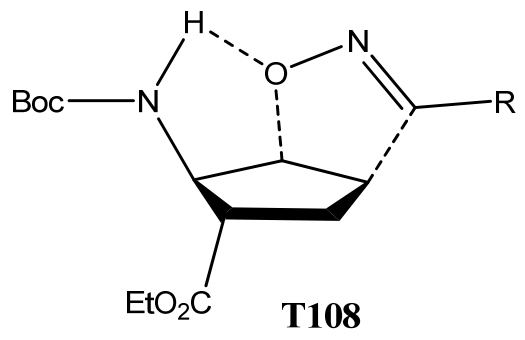

Figure 12. Transition state T108 stabilized by H-bonding interactions during formation of cycloadducts 108a-d.

The stereoselectivity in the reactions of 94 with nitrile oxides (generated from $\mathrm{RNO}_{2}$ and $\mathrm{Boc}_{2} \mathrm{O}$; Scheme 29) can probably be explained analogously. Steric repulsion between the ester moiety and the nitrile oxide determines the stereochemistry of $\mathbf{1 0 3}$ and $\mathbf{1 0 4}$ (Figure 12). An H-bonding interaction between the nitrile oxide and carbamate (cis to $\mathrm{CO}_{2} \mathrm{Et}$ ) may be neglected in these cases ( $\mathbf{T 1 0 3}$ and $\mathbf{T 1 0 4}$ ). The regioselectivity is probably determined by the electron-withdrawing effect of the N-atom of the NHBoc group, favouring attack of the nitrile oxide $\mathrm{O}$-atom on $\mathrm{C}-4$, distant from the carbamate. These two phenomena lead to the major products 103 and 104 (Scheme 29). Formation of the very minor product $\mathbf{1 0 5}$ is an indication that the H-bonding interaction between the carbamate and nitrile oxide in the transition state can just overcome the steric repulsion between the ester and the nitrile oxide (Figure 12). The regioselectivity of the formation of $\mathbf{1 0 5}$ may also be explained on the basis of H-bonding interactions. The postulated transition state T106 involves highly unfavourable steric hindrance not only between the ester and the nitrile oxide, but also between the carbamate and the alkyl moiety $(\mathrm{R})$ of the nitrile oxide. This explains why isomer 106 was never formed (Figure 13, Scheme 29). 

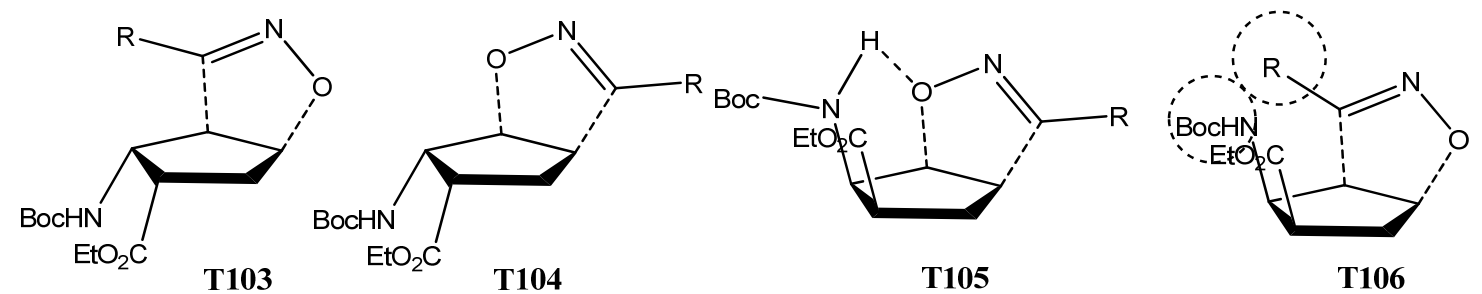

Figure 13. Transition states T103, T104 and T105 in the formation of cycloadducts 103-105; steric repulsions between $\mathrm{CO}_{2} \mathrm{Et}$ and the nitrile oxides in T103 and T104 and between NHBoc and the nitrile oxide and between $\mathrm{CO}_{2} \mathrm{Et}$ and the nitrile oxide in T106, and H-bonding interaction between NHBoc and the nitrile oxide in T105.

The results of calculations at different levels ([B3LYP/6-31++G(d,p), B3LYP/6$311++G(d, p)$ and B3LYP/6-311++G(2d,2p)] agreed well with the experimental finding that the preferred product in the transformation of $\mathbf{1 0 7 b}$ was $\mathbf{1 0 8 b}$ (Table 2, Figure 14).

Table 2. Enthalpy (in $\mathrm{kJ} \mathrm{mol}^{-1}$ ) and Gibbs free energy (in $\mathrm{kJ} \mathrm{mol}^{-1}$ ) of the transformation of $107 \mathrm{~b}$ to $108 \mathrm{~b}, 109 \mathrm{~b}, 110 \mathrm{~b}$ and $111 \mathrm{~b}$.

\begin{tabular}{|c|c|c|c|c|}
\hline & \multicolumn{2}{|c|}{$107 \mathrm{~b} \rightarrow \mathrm{TS}$} & \multicolumn{2}{|c|}{$107 \mathrm{~b} \rightarrow$ products } \\
\hline & $\Delta H^{\ddagger}$ & $\Delta G^{\neq}$ & $\Delta H$ & $\Delta G$ \\
\hline 108 & 47.76 & 102.21 & -170.02 & -106.24 \\
\hline 109 & 65.32 & 119.90 & -154.35 & -92.50 \\
\hline 110 & 76.83 & 130.31 & -152.22 & -90.46 \\
\hline 111 & 55.36 & 113.99 & -163.44 & -100.12 \\
\hline
\end{tabular}

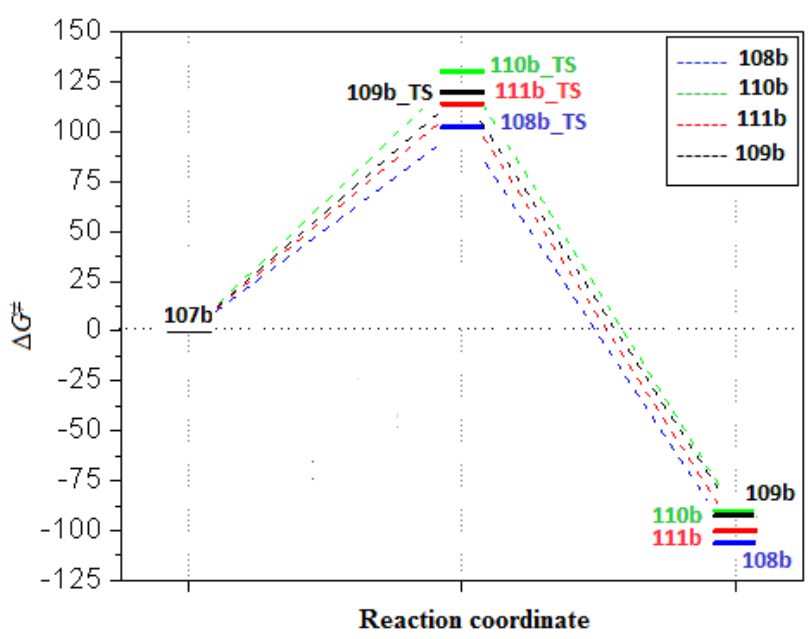

Figure 14. Energy diagram for the transformation of $107 \mathrm{~b}$ to $\mathbf{1 0 8 b}$. 
These computations furnished eloquent proof that the selectivity of nitrile oxide addition to trans-2-aminocyclopentenecarboxylate is largely determined by the H-bonding effect in the transition state (Figure 15).

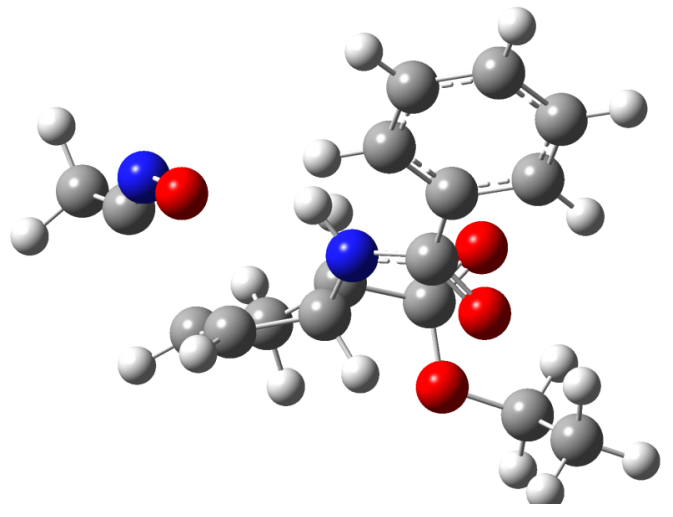

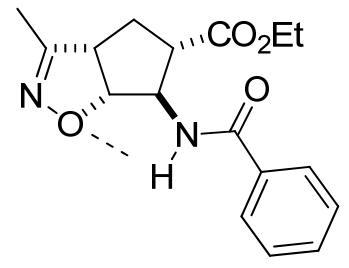

$108 b$ TS

Figure 15. H-bonding stabilization of TS $\mathbf{1 0 8 b}$ in the formation of $\mathbf{1 0 8 b}$.

The reactions of compound $\mathbf{1 1 2}$ illustrated in Scheme 32 gave only one cycloadduct, as expected from the electron-withdrawing effect of the $\mathrm{N}$-atom of the carbamate, in which the isoxazoline ring is trans relative to the carbamate and ester function, and the $\mathrm{O}$-atom of the isoxazoline skeleton is farthest from the carbamate. Moreover, H-bonding interactions were not possible between the diprotected amino function and the nitrile oxide. The same regioselectivity was found in the cycloaddition to ethyl 2-(tert-butoxycarbonylamino)cyclohex-3-enecarboxylate (114, Scheme 33). The cycloaddition reactions of cis- and trans-lactones 96 and 100 selectively furnished only one cycloadduct 117 and 120 (Schemes 34 and 35), in which the H-bonding interaction leads to the isoxazoline ring being cis to the carbamate, while the O-atom of the heterocycle is closest to this group (NHBoc) (Figure 16).

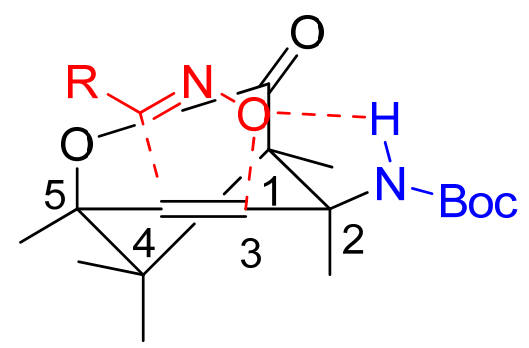

Figure 16. H-bonding interaction between nitrile oxide and carbamate. 


\subsection{Isomerization of isoxazoline-fused cycloadducts}

The $\mathrm{CH}$ group next to the ester function in the $\beta$-aminocarboxylate is an active methyne and its $\mathrm{H}^{+}$can readily be abstracted with base, the generated anion being highly resonance stabilized. The hydrogen abstraction can be performed with Na-alcoholates (e.g. NaOMe or NaOEt). ${ }^{33-42,106}$ The isomerization in the presence of a base is an equilibrium process, which the equilibrium is shifted towards the thermodynamically stable trans ester. The isomerization of the cis cyclic $\beta$-aminocarboxamide derivatives was carried out with $\mathrm{NaOH}$, which provided the corresponding trans isomer in almost quantitative yield. ${ }^{110}$

The earlier synthetized isoxazoline-fused cispentacin derivatives (Scheme 29) offered an opportunity for the preparation of new isoxazoline-fused transpentacin derivatives, regioand stereoisomers of 108. Accordingly, 103a-d and 104a-d were epimerized at C-5 with $\mathrm{NaOEt}$ in EtOH to give izoxazoline-fused amino esters 122a-d and 123a-d, in which the amino and carboxylate functions were trans. Unfortunately, the yields were low and a relatively large quantity of unreacted starting material was recovered during the column chromatography purification of the products (Scheme 36). Polymers were also detected as byproducts by TLC monitoring.
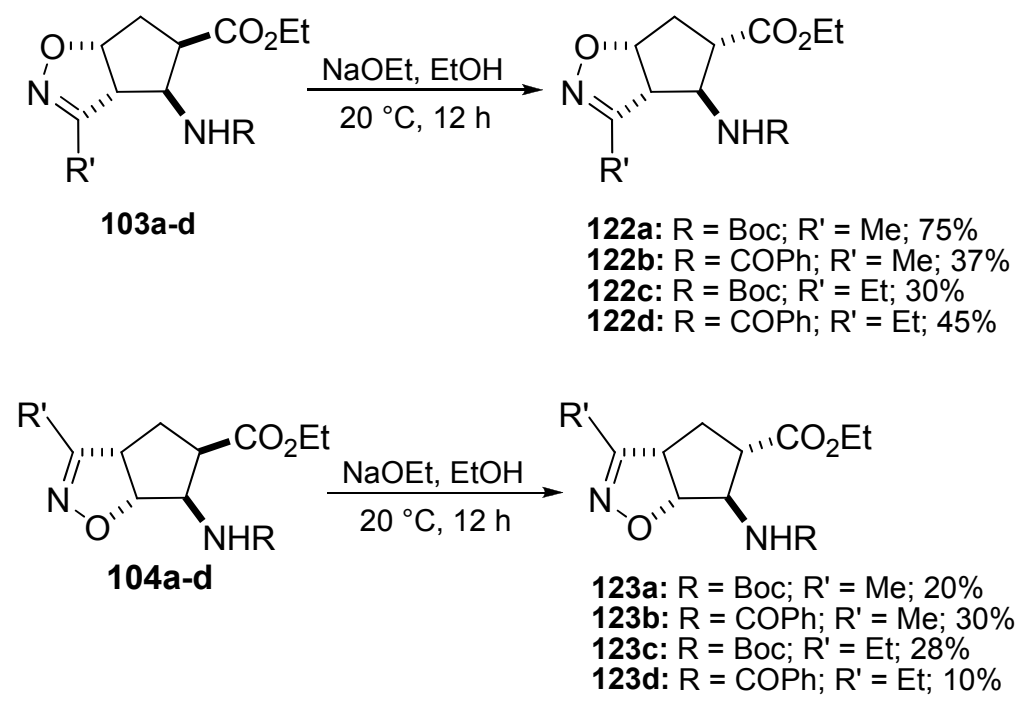

Scheme 36. Syntheses of isoxazoline-fused $\beta$-amino esters 122a-d and 123a-d by epimerization of 103a-d and 104a-d. 


\subsection{Preparation of enantiomerically pure isoxazoline-fused cispentacin and transpentacin derivatives}

The synthesis of enantiomerically pure Boc-protected ethyl-2 aminocyclopentenecarboxylate (-)-94a was achieved by enzymatic resolution of the corresponding bicyclic $\beta$-lactam (discussed in section 3.1). Analogously to its racemic counterpart, compound (-)-94a was submitted to nitrile oxide cycloaddition (see Scheme 29), which resulted in the enantiomerically pure isoxazoline-fused cispentacin derivatives (+)-103a,c and (-)-104a,c and (+)-105a,c (Scheme 37).

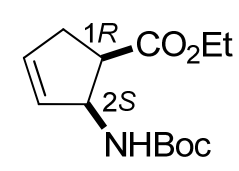

(-)-94a

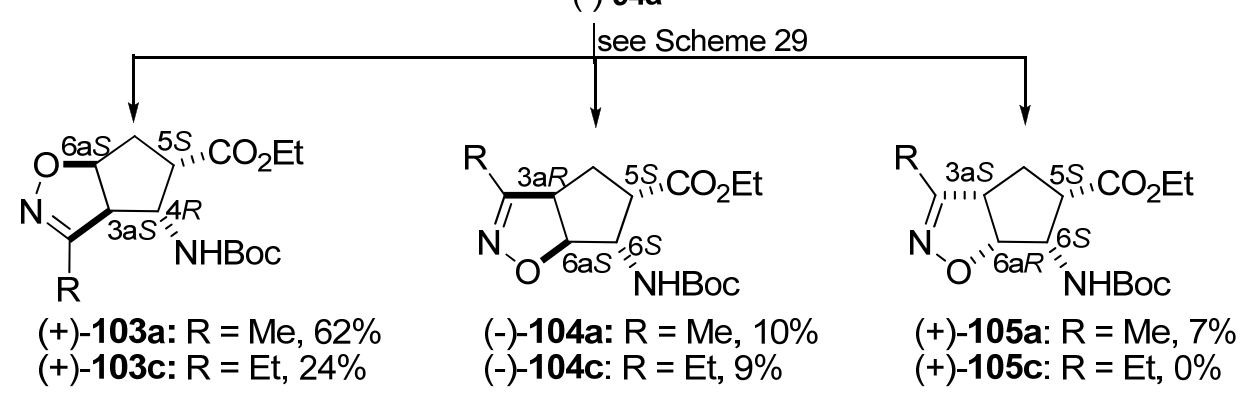

Scheme 37. Syntheses of isoxazoline-annelated ethyl $\beta$-aminocyclopentanecarboxylate enantiomers (+)-103a,c (-)-104a,c and (+)-105a,c.

The ee values of the products were determined by means of gas chromatography, using a Chromopack Chiralsil-Dex CB chiral column; in all cases, ee $>99 \%$ was found. The regio- and stereoselective syntheses of 103a and 103c (Scheme 30) and 108a and 108c (Scheme 31) were also extended to their preparation in enatiomerically pure form through the earlier-mentioned procedures (section 3.1), when the other enantiomer $(+)-94 a$ was used as a dipolarophile (Scheme 38). 


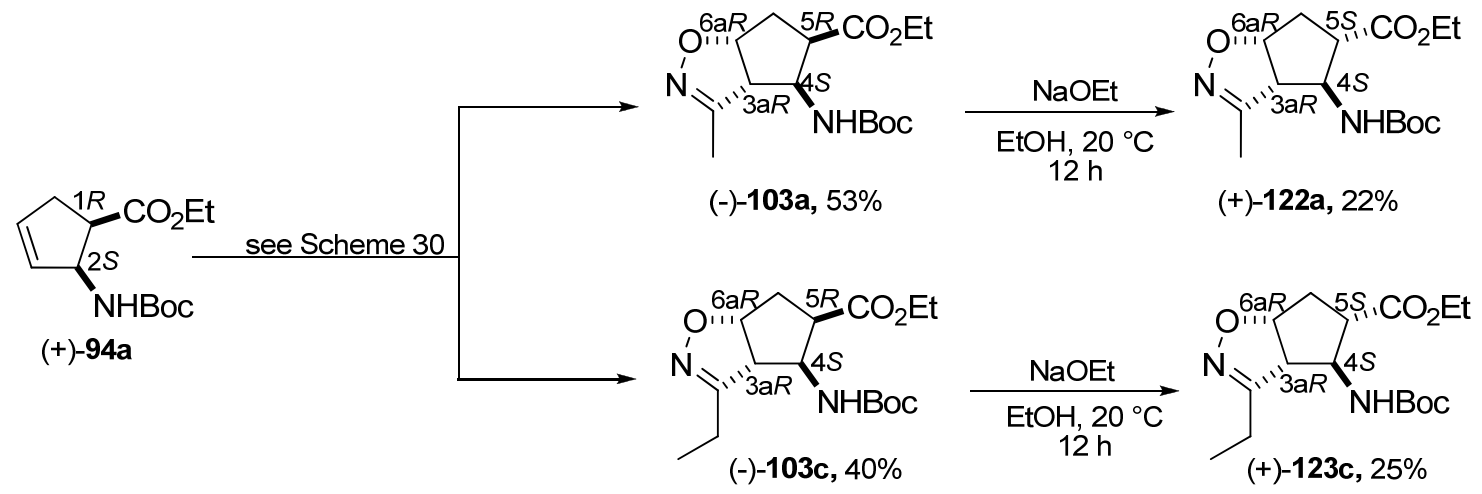

Scheme 38. Syntheses of isoxazoline-fused $\beta$-amino ester enantiomers (-)-103a, (-)-103c, $(+)-122 \mathrm{a}$ and $(+)-122 \mathrm{c}$.

Compounds (-)-103a and (-)-103c were epimerized in the presence of $\mathrm{NaOEt}$ in EtOH to give the enantiomerically pure isoxazoline-fused transpentacin derivatives $(+)$-122a and $(+)-122 c$ (Scheme 38). Next, Boc-protected amino ester (+)-94a was isomerized to its trans derivative $(+)-\mathbf{1 0 7 a}$, which was then subjected to cycloaddition with nitrile oxide (generated from $\mathrm{EtNO}_{2}$ or $\mathrm{PrNO}_{2}, \mathrm{Boc}_{2} \mathrm{O}$ and $\mathrm{Et}_{3} \mathrm{~N}$ ), providing the enantiomerically enriched isoxazoline-fused cispentacin derivatives $(+)-\mathbf{1 0 8 a}$ and $(+)-\mathbf{1 0 8 c}$ in yields of $52 \%$ and $34 \%$ (Scheme 39 ).

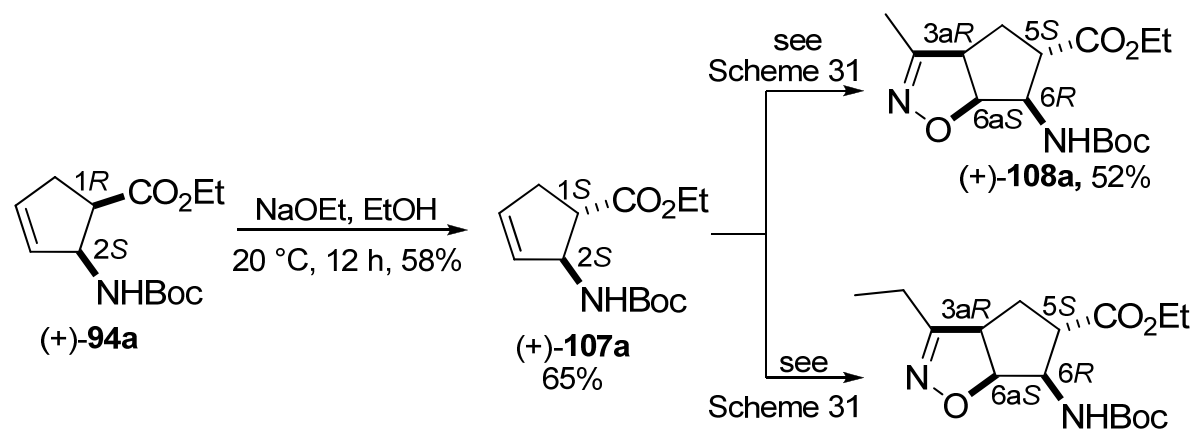

$(+)-108 c, 34 \%$

Scheme 39. Syntheses of isoxazoline-fused $\beta$-amino ester enantiomers $(+)-\mathbf{1 0 8 a}, \mathbf{c}$.

The ee values of the products (-)-103a, (+)-122a and (+)-108a were determined by GC on a Chromopack Chiralsil-Dex CB chiral column, and that for (-)-103c by GC on a CP-Chiralsil L-Val chiral column. The ee value for (+)-108c was determined by HPLC on ChiralcelR OD, and that for (+)-123c by HPLC on Chiral Pak IA. 


\subsection{Reductive opening of the isoxazoline ring}

The isoxazoline ring formed by the 1,3-dipolar cycloaddition nitrile oxide to the cyclopentene or cyclohexene skeleton can be transformed further by reductive ring opening to $\beta$-hydroxy ketones, aminoalcohols or amino acids, etc. ${ }^{71-78}$ Our aim was to synthetize highly functionalized $\beta$-aminocyclopentanecarboxylate regio- and stereoisomers from the earlier-prepared izoxazoline-fused cyclopentane or cyclohexane carboxylates by $\mathrm{N}-\mathrm{O}$ cleavage of the isoxazoline ring.

From among the earlier-prepared isoxazoline-fused cispentacin stereoisomers, we selected a model compound 103a to perform the reduction under different reaction conditions. One of the common reagents applied for reduction of the isoxazoline ring is $\mathrm{NaBH}_{4}$. When the reaction was carried out with this reagent in $\mathrm{EtOH}$ at room temperature, three products were obtained: the epimerized izoxazoline-fused amino carboxylate 122a and amino alcohols 124 and $\mathbf{1 2 5}$, which were separated by chromatography on silica gel (n-hexane/EtOAc) (Scheme 40).

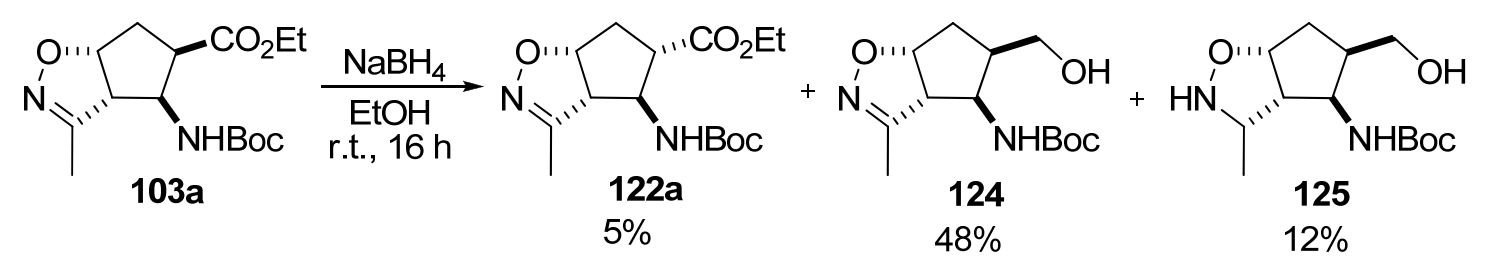

Scheme 40. Treatment of isoxazoline-fused amino ester 103a with $\mathrm{NaBH}_{4}$.

Unfortunately, this reaction did not lead to the formation of a highly functionalized isoxazoline ring-opened $\beta$-amino ester. When the reaction in $\mathrm{EtOH}$ in the presence of $\mathrm{Pd} / \mathrm{C}$ with $\mathrm{HCO}_{2} \mathrm{NH}_{4}$ was investigated for the reduction of 103a, the reaction resulted in compound 126 in rather modest yield. The product was isolated from the crude reaction mixture by column chromatography ( $n$-hexane/EtOAc). The ${ }^{1} \mathrm{H}$ NMR spectrum did not clearly identify the structure of the product, but following the evaluation of the ${ }^{13} \mathrm{C} N \mathrm{NM}$ and $2 \mathrm{D}$ spectra (COSY, NOESY and HSQC) the detected and isolated product proved to be a carbonyl compound, formed through the corresponding hydroxyimine intermediate, followed by elimination and saturation (Scheme 41). 


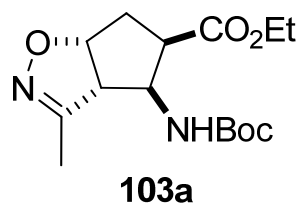

103a

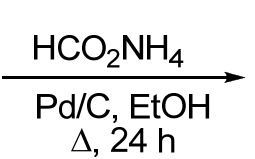

$\Delta, 24 \mathrm{~h}$

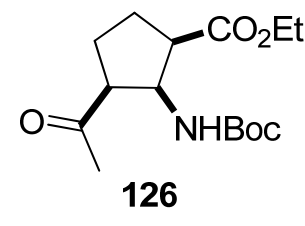

$32 \%$

Scheme 41. Reduction with $\mathrm{Pd} / \mathrm{C}$ in the presence of $\mathrm{HCO}_{2} \mathrm{NH}_{4}$.

Combinations of $\mathrm{NaBH}_{4}$ (as a mild and selective reducing agent) with cobalt, nickel, iridium or rhodium halide have previously been employed for cleavage of the isoxazoline ring system, which is otherwise inert to $\mathrm{NaBH}_{4}$ without such metal halide additives. ${ }^{78}$ Accordingly, we investigated the reduction of isoxazoline-fused amino ester stereoisomers 103a with $\mathrm{NaBH}_{4}$ in the presence of $\mathrm{NiCl}_{2}$ (Scheme 42).
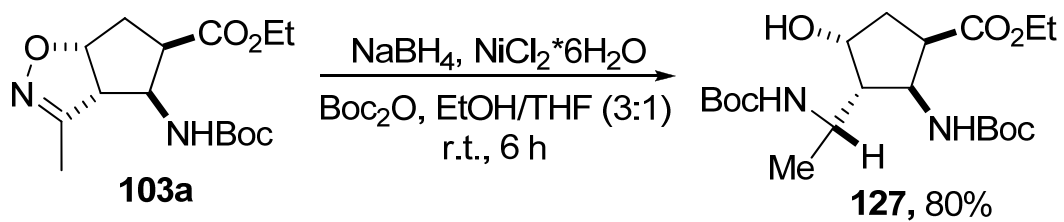

Scheme 42. Transformation of isoxazoline-fused cispentacin stereoisomer 103a into multifunctionalized $\beta$-amino acid derivative 127.

The reduction, carried out by adding $\mathrm{NaBH}_{4}$ to a mixture of $\mathrm{NiCl}_{2}$ and isoxazoline derivative 103a in EtOH/THF, followed by amino group protection with $\mathrm{Boc}_{2} \mathrm{O}$, stereoselectively afforded only one isoxazoline-opened product, 127, as a single diastereomer, in good yield. The reaction was exothermic and deposited a black granular precipitate, reflecting the presence of metal boride. This black precipitate was filtered off on a cellite pad, followed by isolation of the product by column chromatography (n-hexane/EtOAc). The structure of $\mathbf{1 2 7}$ was proved by the ${ }^{1} \mathrm{H}$ NMR, ${ }^{13} \mathrm{C}$ NMR and $2 \mathrm{D}$ spectroscopic data, but the stereochemistry of the new stereocentre remained unsolved. The quality of the crystal permitted the preparation of a crystal suitable for X-ray analysis, and the Ortep diagram confirmed the correct structure (Figure 17). 


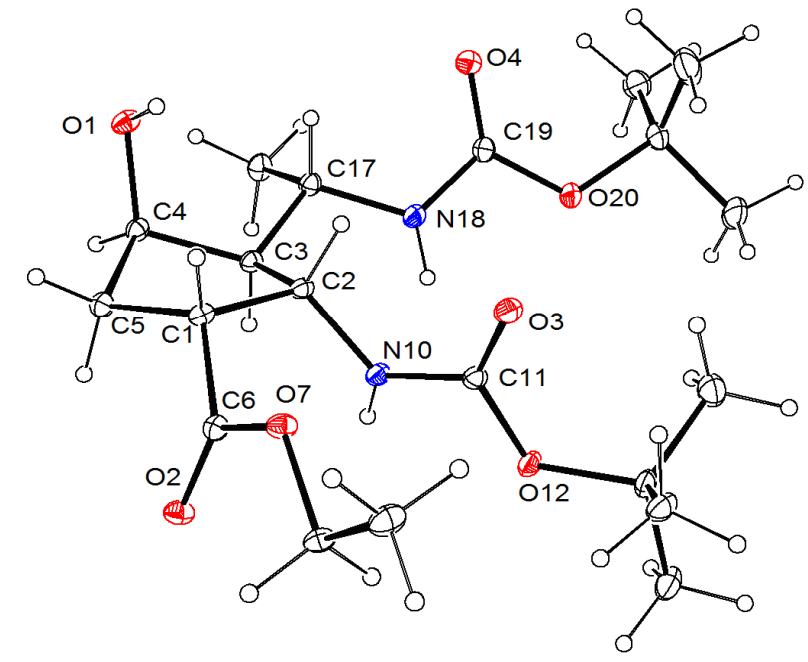

Figure 17. Ortep diagram of compound 123.

Isoxazoline ring opening occurred with the formation of a new stereocentre at a one-carbon distance from $\mathrm{C}-3$. The hydrogenation of the isoxazoline proceeded through hydrogen attack from the carbamate side (cis to NHBoc) of the cyclopentane skeleton, in accordance with literature data. ${ }^{92,93,94-102}$ This procedure appeared to be a convenient method for the preparation of other multifunctionalized amino ester stereoisomers, and we therefore examined the reduction of several isoxazoline-fused cispentacin and transpentacin stereoisomers (104a, 108a, 122a and 123a; Scheme 43). 


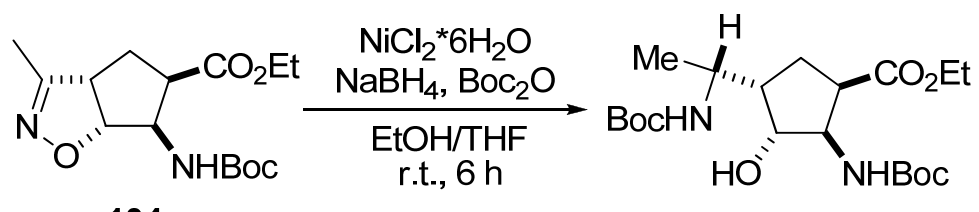

104a<smiles>CCOC(=O)NC1[C@H](C)C[C@@H]2ON=C(C)[C@@H]12</smiles>

$122 a$

$128,72 \%$

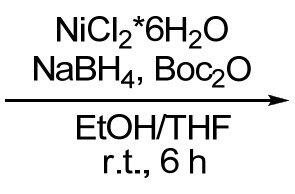

r.t., $6 \mathrm{~h}$

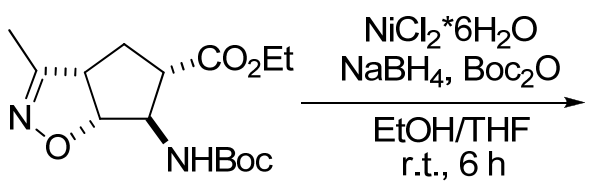

123a

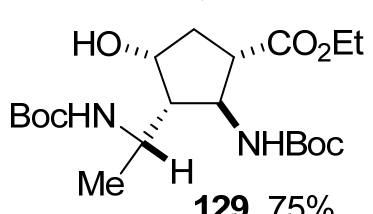

$129,75 \%$

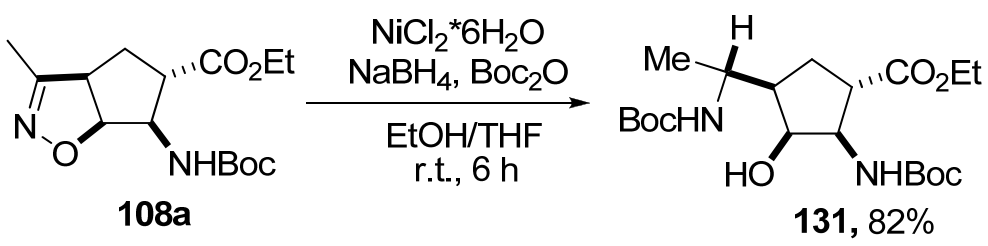

Scheme 43. Syntheses of multifunctionalized $\beta$-amino acid derivatives 128-131.

The ring-opening reactions carried out similarly with $\mathrm{NaBH}_{4}$ in the presence of $\mathrm{NiCl}_{2}$ in $\mathrm{EtOH} / \mathrm{THF}$ led selectively to the corresponding multifunctionalized amino esters 128-131 in good yields, as single diastereoisomers containing a new stereogenic centre. The products were isolated from the metal boride by filtration, followed by purification of the product by column chromatography on silica gel ( $n$-hexane/EtOAc).

Starting from the available isoxazoline-fused $\beta$-amino carboxylates $(118,119$ and 121), multisubstituted $\beta$-amino esters were synthetized selectively by reductive ring opening with $\mathrm{NaBH}_{4}$ in the presence of $\mathrm{NiCl}_{2}$ via the above-mentioned procedure (Scheme 44). 


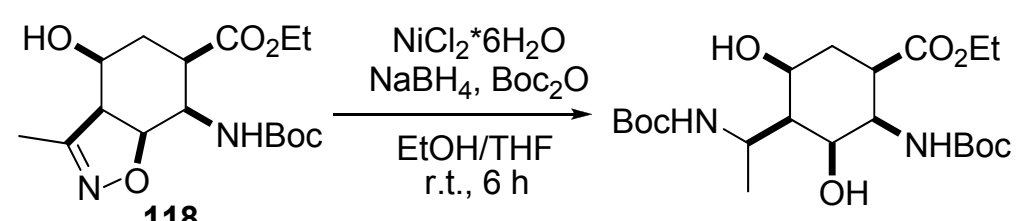

118

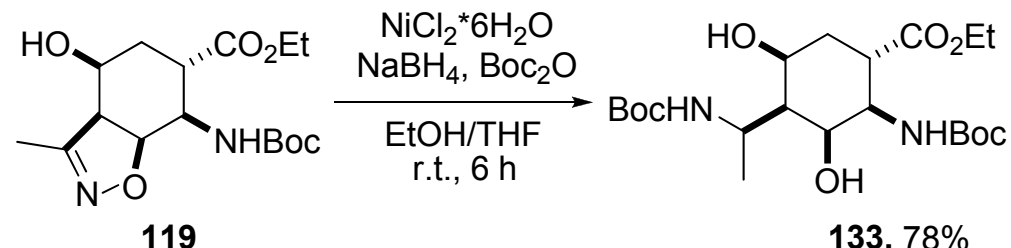

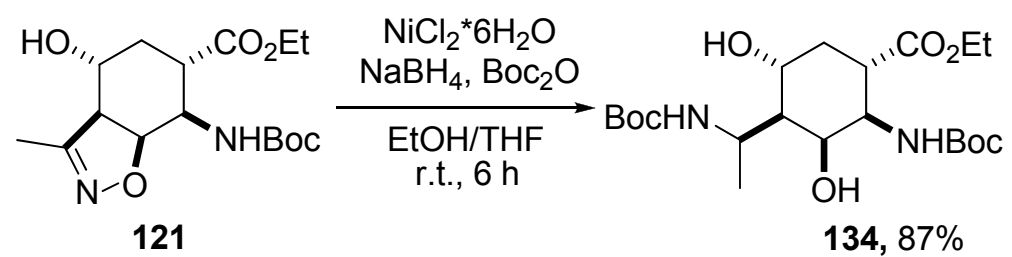

Scheme 44. Syntheses of highly functionalized $\beta$-amino carboxylates 132-134.

The products of the transformation were purified by column chromatography on silica gel ( $n$-hexane/EtOAc). Unfortunately, the preparation of a crystal suitable for X-ray analysis was not succesful, and hence the stereochemistry of the new stereocentre could not be determined, but it most probably corresponds with the earlier experiments where the $\mathrm{H}$ attack occurred from the side of the carbamate (with the formation of a new stereocentre at a onecarbon distance from C-4) (Figure 17). 


\section{SUMMARY}

- Novel isoxazoline-fused cis-2-aminocyclopentanecarboxylate regio- and stereoisomers 103a-d, 104a-d and 105a-d were synthetized by the 1,3-dipolar cycloaddition of nitrile oxide (generated from $\mathrm{EtNO}_{2}$ or $n \mathrm{PrNO}_{2}$, with $\mathrm{Boc}_{2} \mathrm{O}$ as dehydrating agent in the presence of DMAP) to $c i s-2$-aminocyclopentenecarboxylates $(\mathbf{9 4 a}, \mathbf{b})$ in good or moderate overall yields (Scheme 29).

- On change of the dehydrating agent $\mathrm{Boc}_{2} \mathrm{O}$ to $\mathrm{PhNCO}$, high selectivity was observed in the cycloaddition reaction, but the previously detected major product 103a-d was formed and isolated in only moderate yield (Scheme 30). The stereoselectivity of these reactions can be explained by H-bonding steric interactions between the carbamate moiety and the nitrile oxide. The regioselectivity is determined by the electron-withdrawing effect of the $\mathrm{N}$-atom of the amide or carbamate group, favouring attack of the nitrile oxide O-atom on $\mathrm{C}-4$, distant from the carbamate.

- The 1,3-dipolar cycloaddition of nitrile oxide (derived from $\mathrm{EtNO}_{2}$ or $n \mathrm{PrNO}_{2}$ with $\mathrm{Boc}_{2} \mathrm{O}$ and DMAP) to trans-2-aminocyclopentenecarboxylates (107a,b) resulted 100\% regio- and stereoselectively in only one cycloadduct $\mathbf{1 0 8 a - d}$, which could also be prepared in moderate yield by epimerization of the very minor product 105a-d (Scheme 29) at C-5 with NaOEt in EtOH (Scheme 31). The selectivity in the formation of 108a-d is explained by steric and H-bonding interactions. Steric repulsion in the transition state (T108) between the nitrile oxide and the ester function group and a $\mathrm{H}$-bonding interaction between the carbamate and the nitrile oxide are responsible for the observed selectivity, but it is determined by an H-bonding effect in the transition state of the reaction.

- High selectivity was observed in the dipolar cycloaddition of nitrile oxide when Boc-diprotected cis amino ester 112 was used as starting material (Scheme 32). Unfortunately, the yield was rather low: together with the product 113a,b, unreacted starting material 112 was also isolated and recovered during the purification. The selectivities are explained by electronic and steric factors; moreover, H-bonding interactions did not arise between the diprotected amino function and the nitrile oxide. 
- On 1,3-dipolar cyloaddition to ethyl cis-2-aminocyclohex-3-enecarboxylate (114), following the use of $\mathrm{EtNO}_{2}$ for the generation of nitrile oxide, with $\mathrm{Boc}_{2} \mathrm{O}$ and $\mathrm{PhNCO}$ as dehydrating agent in the presence of base, only one isoxazoline derivative 115 was selectively formed and isolated. When compound $\mathbf{1 1 6}$ was applied as a dipolarophile in the 1,3-dipolar cycloaddition of nitrile oxide, no cycloaddition product was detected (Scheme 33), probably because the $\mathrm{C}-\mathrm{C}$ double bond is more isolated from the carbamate and ester functions.

- Cycloaddition to hydroxylated aminocarboxylates 97, 98 and 101 was unsuccessful (Scheme 34). The reactions were carried out under different reaction conditions, such as the Huisgen (from aldoxime) and Mukayama (from primary nitroalkanes) methodologies, but only the starting material was recovered. The reason for this is probably the reduced reactivity of this isolated ring $\mathrm{C}-\mathrm{C}$ double bond. In contrast, $100 \%$ regio- and stereoselectivity was found for the cycloaddition of nitrile oxide (generated from $\mathrm{EtNO}_{2}$, $\mathrm{Boc}_{2} \mathrm{O}$ and DMAP) to cis and trans lactones 96 and 100. Only one product (117 and 120) was detected and isolated (Schemes 34 and 35), in which, as a result of the H-bonding interaction, the isoxazoline ring is cis to the carbamate, while the O-atom of the heterocycle is closest to the NHBoc. Next, these compounds were subjected to lactone opening with $\mathrm{NaOEt}$ in $\mathrm{EtOH}$, whereby the hydroxylated isoxazoline-fused aminocyclohexanecarboxylates 118, 119 and 121 were prepared.

- The isoxazoline-fused cis-2-aminocyclopentanecarboxylates 103a-d, 104a-d were then transformed by epimerization with $\mathrm{NaOEt}$ in $\mathrm{EtOH}$ to the corresponding trans compounds 122a-d, 123a-d (Scheme 36).

- The isoxazoline-fused $\beta$-aminocyclopentenecarboxylates 103a,c, 104a,c, 105a,c, 108a,c, 122a and 123a were prepared in enantiomerically pure form from the Boc-protected ethyl-2-aminocyclopentenecarboxylate enantiomers [(-)-94a and (+)-94a], which were synthetized by the enzymatic resolution of racemic $\beta$-lactam $( \pm)-94 a$ with CAL-B (Schemes 37, 38 and 39).

- Highly functionalized $\beta$-amino acid derivatives 127-134 were synthetized by reductive ring opening of the isoxazoline ring with $\mathrm{NaBH}_{4}$ in the presence of $\mathrm{NiCl}_{2}$, starting from isoxazoline-fused $\beta$-amino acid derivatives 103a, 104a, 122a, 123a, 108a and 118-121 (Schemes 42, 43 and 44). 


\section{ACKNOWLEDGEMENTS}

This work was carried out in the Institute of Pharamceutical Chemistry, University of Szeged between 2007 and 2011.

I am deeply indebted to my supervisor, Professor Ferenc Fülöp, head of the Institute of Pharmaceutical Chemistry, for providing me with the opportunity to perform my work in the Institute. I am grateful for his scientific guidance of my work, his useful advice and his constructive criticism.

I express my special thanks to my co-supervisor, Dr. Loránd Kiss, for introducing me to the preparative organic chemistry work and making me love this field of chemistry, and for his useful advice and continuous support.

I wish to extend my thanks to Dr. Enikő Forró for the preparation of enantiomerically pure starting materials and the GC and HPLC measurements.

I would like to thank Dr. Zoltán Mucsi for the theoretical calculations.

I am grateful to all my colleagues and especially Aranka Polyák, Brigitta Kazi and Maria Cherepanova, for their help and friendship and for providing me with a pleasant working atmosphere.

Finally, I would like to give my warmest thanks to my family and my friends, for their love and support during my $\mathrm{PhD}$ years. 


\section{REFERENCES}

1. Fülöp, F. Chem. Rev. 2001, 101, 2181.

2. Kiss. L.; Forró. E.; Fülöp. F. Synthesis of Carbocyclic $\beta$-Amino Acids. Amino Acids, Peptides and Proteins in Organic Chemistry, Wiley, Weiheim 2009.

3. Kuhl, A.; Hahn, M. G.; Dumic, M.; Mittendorf, J. Amino Acids 2005, 29, 89.

4. $\quad$ Park, K. H.; Kurth, M. J. Tetrahedron 2002, 58, 8629.

5. Pandey, S. K.; Jogdand, G. F.; Oliveira, J. C. A. Mata, R. A.; Rajamohanan, P. R.; Ramana, C. V. Chem. Eur. J. 2011, 17, 12946.

6. Coursindel, T.; Martinez, J.; Parrot, I. Eur. J. Org. Chem. 2011, 4519.

7. Liu, M.; Sibi, M. P. Tetrahedron 2002, 58, 7991.

8. Chandrasekhar, S.; Sudhakar, A.; Kiran, M. U.; Babu, B. N.; Jagadeesh, B. Tetrahedron Lett. 2008, 49, 7368.

9. Mittendorf, J.; Kunisch, F.; Matzke, M.; Militzer, H-C.; Schmidt, A.; Schönfeld, W. Bioorg. Med. Chem. Lett. 2003, 13, 433.

10. Hamersak, Z.; Roje, M.; Avdagic, A.; Sunjic, V. Tetrahedron: Asymmetry 2007, 18, 635.

11. Rathore, N.; Gellman, S. H.; Pablo, J. J. Biophys. J. 2006, 91, 3425.

12. Fernandes, C.; Gauzy, C.; Yang, Y.; Roy, O.; Pereira, E.; Faure, S.; Aitken, D. J. Synthesis 2007, 2222.

13. Miller, J. A.; Nguyen, S. T. Mini Rev. Org. Chem. 2005, 2, 39.

14. Porter, E. A.; Weisblum, B.; Gellman, S. H. J. Am. Chem. Soc. 2005, 127, 11516.

15. Rua, F.; Boussert, F. S.; Parella, T.; Diez-Perez, I.; Branchadell, E. G.; Ortuno, R. M. Org. Lett. 2007, 9, 3643.

16. Torres, E.; Acosta-Silva, C.; Rua, F.; Alvaraez-Larena, A.; Parella, T.; Branchadell, E. G.; Ortuno, R. M. Tetrahedron 2009, 65, 5669.

17. Fernandes, D.; Torres, E.; Aviles, F. X.; Ortuno, R. M. Vendrell, J. Bioorg. Med. Chem. 2009, 17, 3824 .

18. Fernandes, C.; Pereira, E.; Faure, S.; Aitken, D. J.; J. Org. Chem. 2009, 74, 3217.

19. Fernandes, C.; Faure, S.; Pereira, E.; Declerck, V. V. Guillot, R.; Aitken, D. J. Org. Lett. 2010, 12, 3606. 
20. Fülöp, F.; Martinek, T. A.; Tóth, G. K. Chem. Soc. Rev. 2006, 35, 323.

21. Martinek, T. A.; Tóth, G. K.; Vass, E.; Hollósi, M.; Fülöp, F. Angew. Chem. Int. Ed. 2002, 41,1718 .

22. Hetényi, A.; Mándity, I. M.; Martinek, T. A.; Tóth, G. K.; Fülöp, F. J. Am. Chem. Soc. 2005, 127, 547.

23. D'Elia, V.; Zwicknagl, H.; Reiser, O. J. Org. Chem. 2008, 73, 3262.

24. Martinek, T. A.; Fülöp, F. Eur. J. Biochem. 2003, 270, 3657.

25. Choi, S. H.; Guzei, I. A.; Gellman, S. H. J. Am. Chem. Soc. 2007, 129, 13780.

26. Liljeblad, A.; Kanerva, L. T. Tetrahedron 2006, 62, 5831.

27. Gorrea, E.; Nolis, P.; Torres, E.; Da Silva, E.; Amabilino, D. B.; Branchadell, V.; Ortuno, R. M. Chem. Eur. J. 2011, 17, 4588.

28. Sharma, G. V. M.; Reddy, K. S.; Basha, S. J.; Reddy, K. R.; Sarma, A. V. S. Org. Biomol. Chem. 2011, 9, 8102.

29. Forró, E.; Fülöp, F. Mini Rev. Org. Chem. 2004, 1, 93.

30. Cellis, S.; Gorrea, E.; Nolis, P.; Illa, O.; Ortuno, R. M. Org. Biomol. Chem. 2012, 10,861 .

31. Szolnoki, E.; Hetényi, A.; Martinek, T. A.; Szakonyi, Z.; Fülöp, F. Org. Biomol. Chem. 2012, 10, 255.

32. Martinek, T. A.; Fülöp. F. Chem. Soc. Rev. 2012, 41, 687.

33. Kazi, B.; Kiss, L.; Forró, E.; Mándity, I.; Fülöp, F. Arkivoc, 2010, ix, 31.

34. Kiss, L.; Fülöp, F. Synlett, 2010, 1302.

35. Kiss, L.; Forró, E.; Sillanpää, R.; Fülöp, F. Tetrahedron 2010, 66, 3599.

36. Kiss, L.; Forró, E.; Sillanpää, R.; Fülöp, F. Synthesis 2010, 153.

37. Kiss, L.; Forró, E.; Sillanpää, R.; Fülöp, F. Nucleic Acids Symposium Series 2008, 52,551 .

38. Kiss, L.; Forró, E.; Sillanpää, R.; Fülöp, F. Tetrahedron: Asymmetry 2008, 19, 2856.

39. Kiss, L.; Forró, E.; Martinek, T. A.; Bernáth, G.; De Kimpe, N.; Fülöp, F. Tetrahedron 2008, 64, 5036.

40. Kiss, L.; Kazi, B.; Forró, E.; Fülöp, F. Tetrahedron Lett. 2008, 49, 339.

41. Kiss, L.; Forró, E.; Fustero, S.; Fülöp, F. Org. Biomol. Chem. 2011, 9, 6528.

42. Kiss, L.; Forró, E.; Fustero, S.; Fülöp, F. Eur. J. Org. Chem. 2011, 4993. 
43. Smith, L. I. Chem. Rev. 1938, 23, 757.

44. Huisgen, R. Angew. Chem. Int. Ed. Engl. 1963, 2, 565.

45. Huisgen, R. Angew. Chem. Int. Ed. Engl. 1963, 2, 633.

46. Nájera, C.; Sansano, J. Org. Biomol. Chem. 2009, 7, 4567.

47. Kissane, M.; Maguire, A., R. Chem. Soc. Rev. 2010, 39, 845.

48. Najera, C.; Sansano, J. M. Org. Biomol. Chem. 2009, 7, 4567.

49. Nair, V.; Suja, T. D. Tetrahedron, 2007, 63, 12247.

50. Gothelf, K. V.; Jorgensen, K. A. Chem. Rev. 1998, 98, 863.

51. Gallos, J. K.; Koumbis, A. E. Curr. Org. Chem. 2003, 7, 397.

52. Pellisier, H. Tetrahedron, 2007, 63, 3235.

53. Engels, B.; Christl, M. Angew. Chem. Int. Ed. 2009, 48, 7968.

54. Kobayashi, S., Jorgensen, K. A. Cycloaddition Reactions in Organic Synthesis, Wiley-VCH: Weiheim 2002.

55. Torsell, K. B. G. Nitrile Oxides, Nitrones and Nitronates in Organic Synthesis, New York, VCH, 2008.

56. Namboothiri, I. N. N.; Rastogi, N.; Ganguly, B.; Mobin, S. M.; Cojocaru, M. Tetrahedron, 2004, 60, 1453.

57. Fuller, A. A.; Chen, B.; Minter, A. R.; Mapp, A. K. J. Am. Chem. Soc. 2005, 127, 5376.

58. Bode, J. W.; Fraefel, N.; Muri, D.; Carreira, E. M. Angew. Chem. Int. Ed. 2001, 40, 2082

59. Tangallapally, R. P.; Rakesh, D. S.; Budha, N.; Lee, R. E. B.; Lenaerts, A. J. M.; Meibohm, B.; Lee, R. E. Bioorg. Med. Chem. Lett. 2007, 17, 6638.

60. Sielecki, T. M.; Liu, J.; Mousa, S. A:; Racanelli, A. L.; Hausner, E.A.; Wexler, R. R.; Olson, R. E. Bioorg. Med. Chem. Lett. 2001, 11, 2201.

61. Gaonkar, S. L.; Rai, K. M. L.; Prabhuswamy, B. Med. Chem. Res. 2007, 15, 407.

62. Kozikowski, A. P.; Tapadar, S.; Luchini, D. N.; Kim, K. H.; Billadeau, D. D. J. Med. Chem. 2008, 51, 4370.

63. Kai, H.; Matsumoto, H.; Hattori, N.; Takase, A.; Fujiwara, T.; Sugimoto, H. Bioorg. Med. Chem. Lett. 2001, 11, 1997. 
64. Basappa, M.; Sadashiva, P.; Mantelingu, K.; Swamy, N. S.; Rangappa, K. S. Bioorg. Med. Chem. 2003, 11, 4539.

65. Lam, P. Y. S.; Adams, J. J.; Clark, C. G.; Calhoun, W. J.; Luettgen, J. M.; Knabb, R. M.; Wexler, R. R. Bioorg. Med. Chem. Lett. 2003, 13, 1795.

66. Barbachyn, M. R.; Cleek, G. J.; Dolak, L. A.; Garmon, S. A.; Morris, J.; Seest, E. P.; Thomas, R. C.; Toops, D. S.; Watt, W.; Wishka, D. G.; Ford, C. W.; Zurenko, G. E.; Hamel, J. C.; Schaadt, R. D.; Stapert, D.; Yagi, B. H.; Adams, W. J.; Friis, J. M.; Slatter, J. G.; Sams, J. P.; Oien, N. L.; Zaya, M. J.; Wienkers, L. C.; Wynalda, M. A. J. Med. Chem. 2003, 46, 284.

67. Pirrung, M. C.; Tumey, L. N.; Raetz, C. R. H.; Jackman, J. E.; Snehalatha, K.; McClerren, A. L.; Fierke, C. A.; Gantt, S. L.; Rusche, K. M. J. Med. Chem. 2002, $45,4359$.

68. Christl, M.; Huisgen, R. Chem. Ber. 1973, 106, 3345.

69. Mukaiyama, T.; Hoshino, T. J. Am. Chem. Soc. 1960, 62, 5339.

70. Caramella, P; Grünanger, P. 1,3-Dipolar Cycloaddition Chemistry, New York, Wiley-Interscience, 1984.

71. Tokizane, M.; Sato, K.; Ohta, T.; Ito, Y. Tetrahedron: Asymmetry, 2008, 19, 2519.

72. Jiang, D.; Chen, Y. J. Org. Chem. 2008, 73, 9181.

73. Tang, S.; He, J.; Sun, Y.; He, L.; She, X. J. Org. Chem. 2010, 75, 1961.

74. Gothelf, K., V.; Jorgensen, K. A. Chem. Rev. 1998, $98,863$.

75. Minter, A. R.; Fuller, A. A.; Mapp, A. K. J. Am. Chem. Soc. 2003, 125, 6846.

76. Fuller, A. A.; Chen, B.; Minter, A. R.; Mapp, A. K. J. Am. Chem. Soc. 2005, 127, 5376.

77. Sewald, N. Angew. Chem. Int. Ed. 2003, 42, 5794.

78. Jiang, H.; Elsner, P.; Jensen, K., L.; Falcicchio, A.; Marcos, V.; Jorgensen, K., A. Angew. Chem. Int. Ed. 2009, 48, 6844.

79. Quadrelli, P.; Scrocchi, R.; Caramella, P.; Rescifina, A.; Piperno, A. Tetrahedron, 2004, 60, 3643.

80. Quadrelli, P.; Mella, M.; Assanelli, G.; Picanello, A. Tetrahedron, 2008, 64, 7312.

81. Quadrelli, P.; Bovio, B.; Piccinini, A.; Caramella, P.; De Sarlo, F.; Machetti, F. Tetrahedron, 2009, 65, 10679. 
82. Quadrelli, P.; Picanello, A.; Martinez, N., V.; Bovio, B.; Mella, M.; Caramella, P. Tetrahedron, 2006, 62, 7370 .

83. Quadrelli, P.; Piccanello, A.; Mella, M.; Corsaro, A.; Pistara, V. Tetrahedron, 2008, 64,3541 .

84. Memeo, M., G.; Bovio, B.; Quadrelli, P. Tetrahedron, 2011, 67, 1907.

85. Savion, M.; Memeo, M. G.; Bovio, B.; Legnani, L.; Quadrelli, P. Tetrahedron 2012, 68, 1845.

86. Moggio, Y.; Legnani, L.; Bovio, B.; Memeo, M. G; Quadrelli, P. Tetrahedron, 2012, 68, 1384.

87. Conti. P.; De Amici, M.; Joppolo di Ventimiglia, S.; Stensbol, T., B.; Madsen, U.; Bräuner-Osborne, H.; Russo, E.; De Sarro, G.; Bruno, G.; De Micheli, C. J. Med. Chem. 2003, 46, 3102.

88. Roda, G.; Conti, P.; De Amici, M.; He, J.; Polavarapu, P., L.; De Micheli, C. Tetrahedron: Asymmetry, 2004, 15, 3079.

89. Conti, P.; Caligiuri, A.; Pinto, A.; Roda, G.; Tamborini, L.; Nielsen, B.; Madsen, U.; Frydenvang, K.; Colombo, A.; De Micheli, C. Eur. J. Med. Chem. 2007, 42, 1059 .

90. Pinto, A.; Conti, P.; Grazioso, G.; Tamborini, L.; Madsen, U.; Nielsen, B.; De Micheli, C. Eur. J. Med. Chem. 2011, 46, 787.

91. Pinto, A.; Conti, P.; De Amici, M.; Tamborini, L.; Grazioso, G.; Colleoni, S.; Mennini, T.; Gobbi, M.; De micheli, C. Tetrahedron: Asymmetry, 2008, 19, 867.

92. Park, K.; Olmstead, M. M.; Kurth, M. J. J. Org. Chem. 1998, 63, 113.

93. Park, K.; Kurth, M. J. J. Org. Chem. 2000, 65, 3520.

94. Chand, P.; Kotian, P. L.; Dehghani, A.; El-Kattan, Y.; Lin, T.; Hutchison, T. L.; Babu, Y. S.; Bantia, S.; Elliott, A. J.; Montgomery, J. A. J. Med. Chem. 2001, 44, 4379 .

95. Chand, P.; Bantia, S.; Kotian, P. L.; El-Kattan, Y.; Lin, T.; Babu, Y. S. Bioorg. Med. Chem. 2005, 13, 4071.

96. Yi, X.; Guo, Z.; Chu, F. M. Bioorg. Med. Chem. 2003, 11, 1465.

97. Mineno, T.; Miller, M. J. J. Org. Chem. 2003, 68, 6591. 
98. Chand, P.; Babu, Y. S.; Bantia, S.; Rowland, S.; Dehghani, A.; Kotian, P. L.; Hutchison, T. L.; Ali, S.; Brouillette, W.; El-Kattan, Y.; Lin, T. J. Med. Chem. 2004, 47, 1919.

99. Lü, W. J.; Chen, Y. L.; Ma, W. P.; Zhang, X. Y.; Luan, F.; Liu, M. C.; Chen, X. G.; Hu, Z. D. Eur. J. Med. Chem. 2008, 43, 569.

100. Oakley, A. J.; Barrett, S.; Peat, T. S.; Newman, J.; Streltsov, V. A.; Waddington, L.; Saito, T.; Tashiro, M.; McKimm-Breschkin, J. L. J. Med. Chem. 2010, 53, 6421.

101. Cui, Y.; Jiao, Z.; Gong, J.; Yu, Q.; Zheng, X.; Quan, J.; Luo, M.; Yang, Z. Org. Lett. 2010, 12, 4.

102. Bromba, C. M.; Mason, J. W.; Brant.; M. G.; Chan, T.; Lunke, M. D.; Petric, M.; Boulanger, M. J.; Wulff, J. E. Bioorg. Med. Chem. Lett. 2011, 21, 7137.

103. Forró, E.; Schönstein, L.; Kiss, L.; Vega-Peñaloza, A.; Juaristi, E.; Fülöp, F. Molecules 2010, 15, 3998.

104. Forró, E.; Fülöp, F. Tetrahedron: Asymmetry, 2004, 15, 2875.

105. Forró, E. J. Chromat. A. 2009, 1216, 1025.

106. Kiss, L.; Forró, E.; Sillanpää, R.; Fülöp, F. J. Org. Chem. 2007, 72, 8786.

107. Becke, A.D. J. Chem. Phys. 1993, 98, 5648.

108. Frisch, M. J.; Trucks, G. W.; Schlegel, H. B.; Scuseria, G. E.; et al. Gaussian 03, revision B.05; Gaussian, Inc., Pittsburgh, PA, 2003.

109. Mucsi, Z.; Szabó, A.; Hermecz, I.; Kucsman, Á.; Csizmadia, I. G. J. Am. Chem. Soc. 2005, 127, 7615.

110. Fernandes, C.; Pereira, E.; Faure, S.; Aitken, D. J. J. Org. Chem. 2009, 74, 3217. 
ANNEX 
I. 


\title{
Synthesis of novel isoxazoline-fused cispentacin stereoisomers
}

\author{
Loránd Kiss $^{\mathrm{a}}$, Melinda Nonn ${ }^{\mathrm{a}}$, Enikő Forró ${ }^{\mathrm{a}}$, Reijo Sillanpää ${ }^{\mathrm{c}}$, Ferenc Fülöp ${ }^{\mathrm{a}, \mathrm{b}, *}$ \\ a Institute of Pharmaceutical Chemistry, University of Szeged, H-6720 Szeged, Eötvös u. 6, Hungary \\ ${ }^{\mathrm{b}}$ Research Group of Stereochemistry of the Hungarian Academy of Sciences, University of Szeged, H-6720 Szeged, Eötvös u. 6, Hungary \\ c Department of Chemistry, University of Jyväskylä, FIN-40351, Jyväskylä, Finland
}

\section{A R T I C L E I N F O}

\section{Article history:}

Received 16 January 2009

Revised 5 March 2009

Accepted 17 March 2009

Available online 21 March 2009

Keywords:

Cycloadditions

Amino acids

Heterocycles

Bicyclic compounds

Carbocycles

\begin{abstract}
A B S T R A C T
New isoxazoline-fused cispentacins were prepared by the 1,3-dipolar cycloaddition of nitrile oxides to $\beta$ amino esters containing a cyclopentene skeleton. This synthetic procedure gave regio- and diastereoisomers of the cispentacins. The synthetic route was extended to the synthesis of these compounds in enantiomerically pure form.
\end{abstract}

() 2009 Elsevier Ltd. All rights reserved.
Isoxazolines, are versatile intermediates for the synthesis of a variety of bioactive compounds. ${ }^{1,2}$ Substituted isoxazolines display, for example, anti-influenza activity $^{3}$ and antifungal properties. 4

The 1,3-dipolar cycloaddition of nitrile oxides to alkenes is a widely used, efficient method for the synthesis of isoxazolines. ${ }^{5} \mathrm{Ni}-$ trile oxides can be generated in situ by either (i) base-induced dehydrohalogenation of hydroximoyl chlorides ${ }^{6}$ (Huisgen methodology), or (ii) dehydration of primary nitroalkane derivatives ${ }^{7}$ (Mukaiyama methodology). Isoxazole carboxylic acids such as conformationally constrained aspartate and glutamate analogs were recently synthesized via the 1,3-dipolar cycloaddition of nitrile oxides to $\alpha$-amino esters with a cyclopentene skeleton. ${ }^{8}$ These derivatives proved to be inhibitors of excitatory amino acid transporters with neuroprotective activity. ${ }^{8}$ Nitrile oxide cycloaddition to $\alpha$-amino esters with a cyclopentene framework furnished isoxazoline-substituted diketopiperazines. ${ }^{9}$ The 1,3 -dipolar cycloaddition of nitrile oxides to $\gamma$-amino acids with a cyclopentene skeleton is the key step in the stereoselective synthesis of novel multisubstituted cyclopentene derivatives (BCX-1812, BCX-1827, etc.) which possess antiviral activity. ${ }^{10} \mathrm{~A}$ novel approach to isoxazoline-carbocyclic nucleosides involves the regio- and stereoselective 1,3-dipolar cycloaddition of nitrile oxides to 2azanorbornenes, followed by ring opening and a purine or pyrimidine base construction strategy. ${ }^{11}$

\footnotetext{
* Corresponding author. Tel.: +36 62 545564; fax: +36 62545705.

E-mail address: fulop@pharm.u-szeged.hu (F. Fülöp).
}

Alicyclic $\beta$-amino acids have received significant interest in recent years as a consequence of their pharmacological potential. ${ }^{12}$ The naturally occurring $\beta$-amino acid cispentacin ( $1 R, 2 S$-2-aminocyclopentanecarboxylic acid), an antifungal antibiotic, is a very important member of this class of compounds. $(1 R, 2 S)-2$-Amino4-methylenecyclopentanecarboxylic acid (Icofungipen), is for example, a strong antifungal agent. ${ }^{12 b}$ Many cyclic, conformationally restricted $\beta$-amino acids have been used as building blocks for the synthesis of peptides. ${ }^{13}$

To our knowledge, cispentacin derivatives fused with a heterocyclic ring have not been prepared. Our present aim was to synthesize novel, isoxazoline-fused $\beta$-aminocyclopentanecarboxylate regio- and stereoisomers in racemic or enantiomerically pure form, starting from the corresponding $\mathrm{N}$-protected ethyl 2-amino-3cyclopentenecarboxylates $\mathbf{1 a}-\mathbf{b}$ as dipolarophiles. The nitrile oxide was generated using nitroethane in the presence of $\mathrm{Boc}_{2} \mathrm{O}$ and 4dimethylaminopyridine (DMAP). When amino ester $\mathbf{1 a}(\mathrm{R}=\mathrm{Boc})$ was submitted to the cycloaddition in THF at $20^{\circ} \mathrm{C}$ for $15 \mathrm{~h}$, two regioisomers $\mathbf{2 a}$ and $\mathbf{3 a}$ (in which the isoxazoline ring is trans relative to the ester and amino functions) were formed in good overall yield (67\%) in a ratio of $10: 1$. A third isomer $\mathbf{4 a}$, in which the isoxazoline ring is cis arranged relative to the ester and amino moieties, was isolated from the reaction mixture, but only in low yield (6\%) (Scheme 1). When the reaction was performed under similar conditions with the benzoyl-protected derivative $\mathbf{1 b}$, the overall yield increased (87\%) and two trans-products, $\mathbf{2 b}$ (Fig. 1) and $\mathbf{3 b}$, and a cis-derivative $\mathbf{4 b}$ were isolated (Scheme 1 ). The ratio of $\mathbf{2 b}: \mathbf{3 b}(5.7: 1)$ was lower in comparison with that of $\mathbf{2 a}$ :3a. The regio- and stereoisomers were separated and isolated by column 


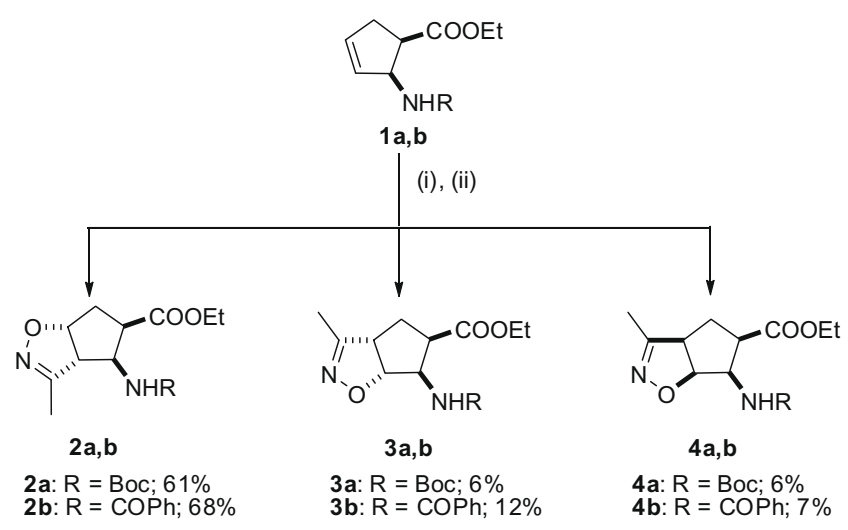

Scheme 1. Synthesis of isoxazoline-fused ethyl 2-aminocyclopentanecarboxylates: (i) nitroethane, $\mathrm{Boc}_{2} \mathrm{O}$, DMAP, THF, $20^{\circ} \mathrm{C}, 15 \mathrm{~h}$; (ii) column chromatography.

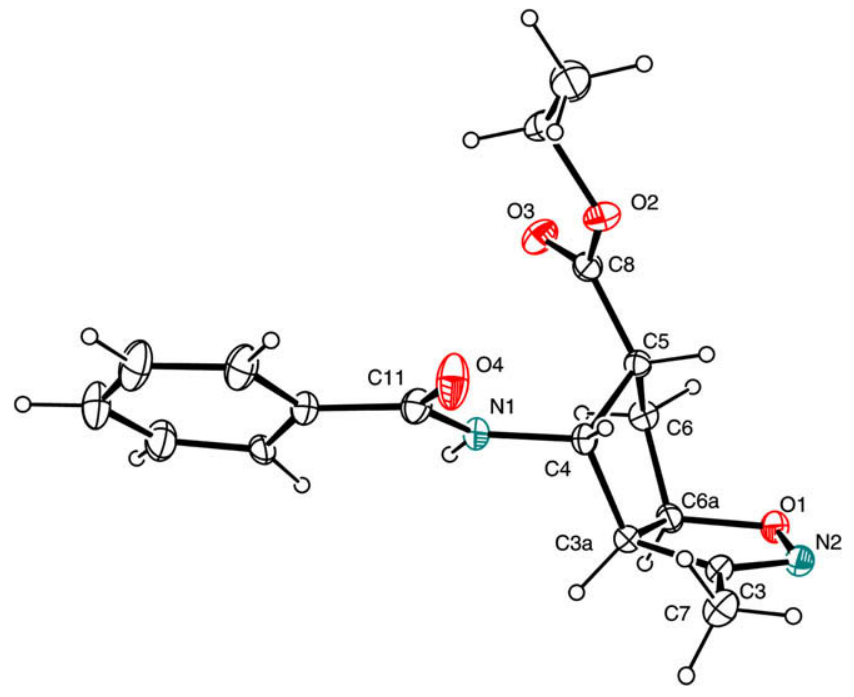

Figure 1. ORTEP diagram of compound $\mathbf{2 b}$

chromatography on silica gel, and their structures were elucidated by X-ray and 2D NMR analysis.

In all cases, the trans-isoxazoline derivatives $\mathbf{2 a} \mathbf{a}, \mathbf{b}$ were formed as major products, with the oxygen atom of the isoxazoline unit furthest from the carbamate or amide group. This regioselectivity is probably best explained by electronic factors, the negatively charged oxygen of the dipolar agent prefers to attack the carbon atom of amino ester 1a,b most distant from the carbamate or amide group because of the electron-withdrawing effect of the nitrogen atom at position 4 of the cyclopentane skeleton. Similar regioselectivities were observed in the reactions of nitrile oxides with $\gamma$-amino carboxylates with a cyclopentene skeleton. ${ }^{10}$

Experiments were next performed with a primary nitroalkane homolog. The cycloadditions of 1-nitropropane to 1a,b were performed under similar conditions as previously described for nitroethane. As expected the main products formed in the cycloaddition of Boc-protected derivative 1a were the trans-isoxazoline derivatives $\mathbf{5 a}$ and $\mathbf{6 a}$ in $50 \%$ overall yield, the major product being regioisomer 5a (Scheme 2). The cis-isomer was not detected in the reaction mixture. It is noteworthy that the ratio of the two transisomers (5a and $\mathbf{6 a}$ ) in this case was only $2.3: 1$, that is, much lower than that was found for nitroethane.

With the benzoyl-protected $\beta$-amino ester $\mathbf{1 b}$ under the same conditions, the cis-stereoisomer $\mathbf{7 b}(5 \%)$ was isolated together with the main trans-derivatives $\mathbf{5 b}$ in $40 \%$ yield (Fig. 2 ) and $\mathbf{6 b}$ in $10 \%$ yield (Fig. 3).

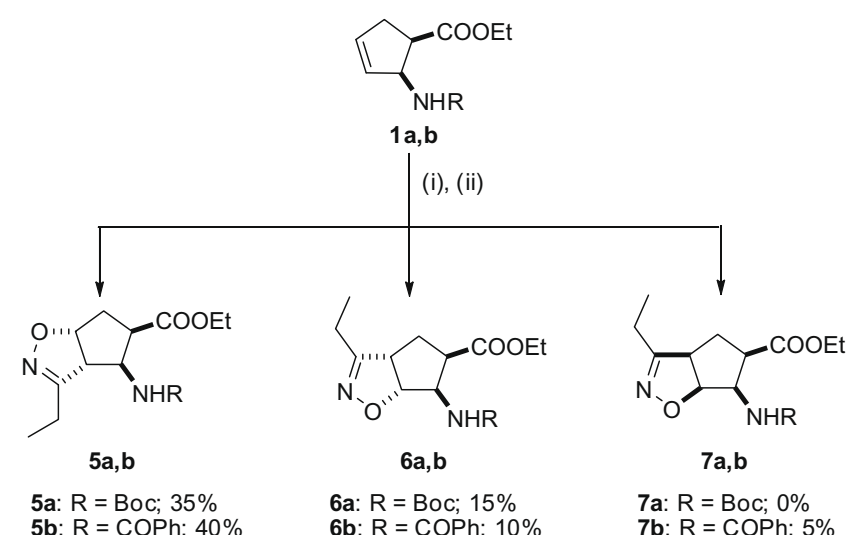

Scheme 2. Synthesis of isoxazoline-fused ethyl $\beta$-aminocyclopentanecarboxylates: (i) 1-nitropropane, $\mathrm{Boc}_{2} \mathrm{O}$, DMAP, THF, $20^{\circ} \mathrm{C}, 15 \mathrm{~h}$; (ii) column chromatography.

The synthetic route was next applied to synthesize enantiomerically pure isoxazoline-fused $\beta$-aminocyclopentane carboxylates (Scheme 3). The enantiomerically pure Boc-protected amino ester $(-)-\mathbf{1} \mathbf{a}^{14}$ was transformed (without affecting the stereocenters) in reactions with both nitrile oxide species (derived from nitropropane or nitroethane) into the corresponding isoxazoline-fused $\beta$ aminocyclopentanecarboxylate enantiomers (Scheme 3).

In summary, novel, regio-, and stereoisomers of isoxazolinefused cispentacin derivatives have been synthesized via 1,3-dipolar cycloadditions of nitrile oxides to ethyl 2-amino-3-cyclopentenecarboxylates. This synthetic pathway was also applied for the preparation of these new compounds in enantiomerically enriched form. Although, the cycloaddition was not completely selective, it permitted preparation of three different regio- and diastereoisomers of isoxazoline-fused cispentacin derivatives.

The ee values of $\mathbf{2 a - 6 a}$ were determined by gas chromatography using a chiral column: Chromopack Chiralsil-Dex CB column $(25 \mathrm{~m})\left[190{ }^{\circ} \mathrm{C} ; 140 \mathrm{kPa}\right]$; retention times (min), (+)-2a: 20.48 (antipode: 20.16); (-)-3a: 32.97 (antipode: 30.88); (+)-4a: 24.69 (antipode: 25.88); (+)-6a: 42.11 (antipode: 40.16); Chromopack L-Val column $(25 \mathrm{~m})$ [ $\left.190{ }^{\circ} \mathrm{C} ; 140 \mathrm{kPa}\right]$; retention times (min), (+)-5a: 9.43 (antipode: 8.95).

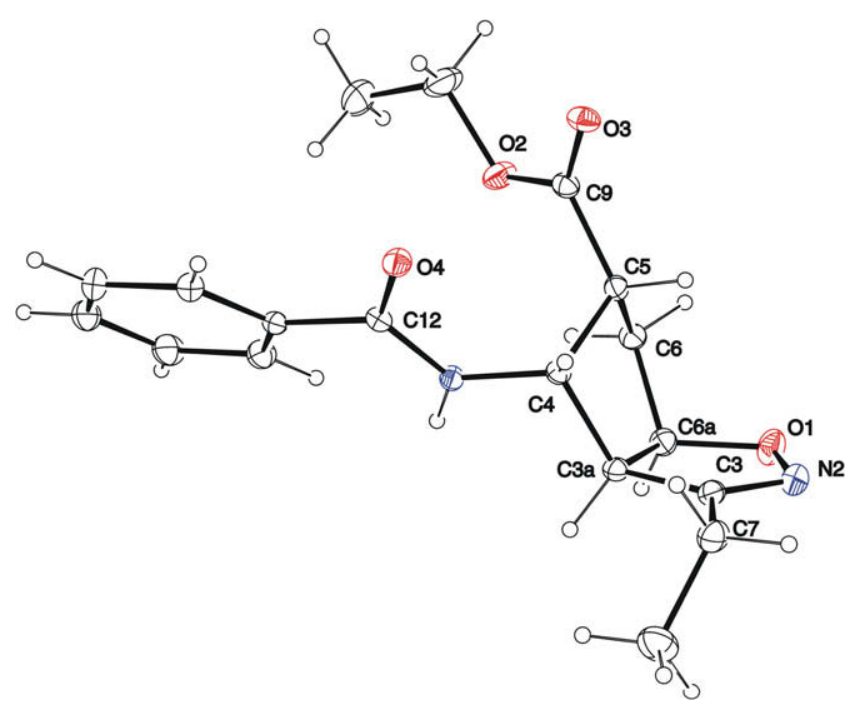

Figure 2. ORTEP diagram of compound $\mathbf{5 b}$. 


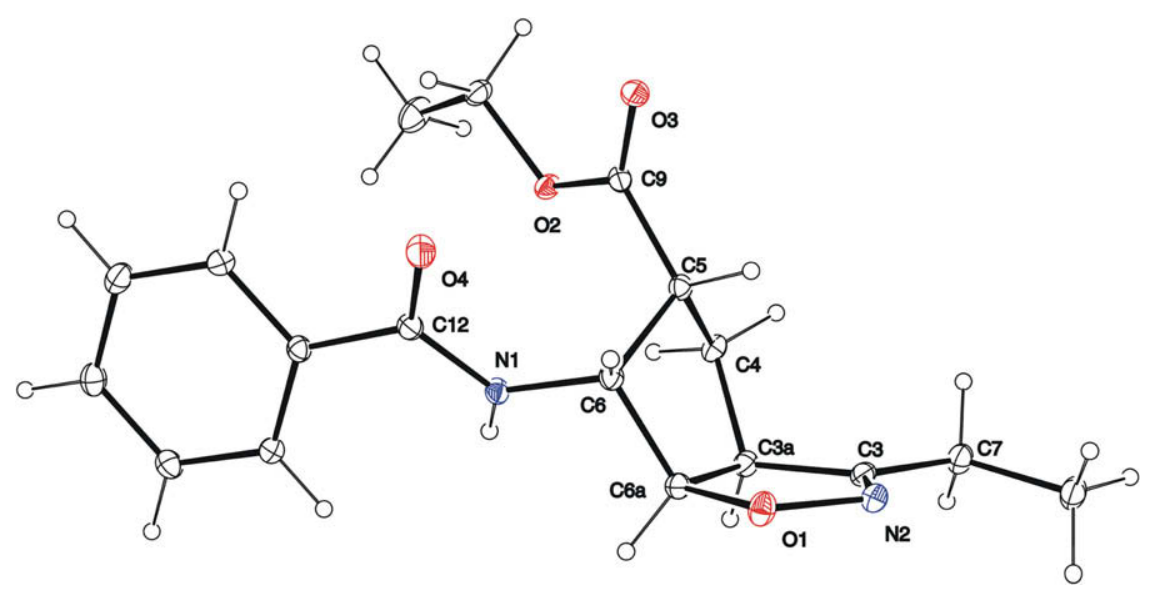

Figure 3. ORTEP diagram of compound $\mathbf{6 b}$.

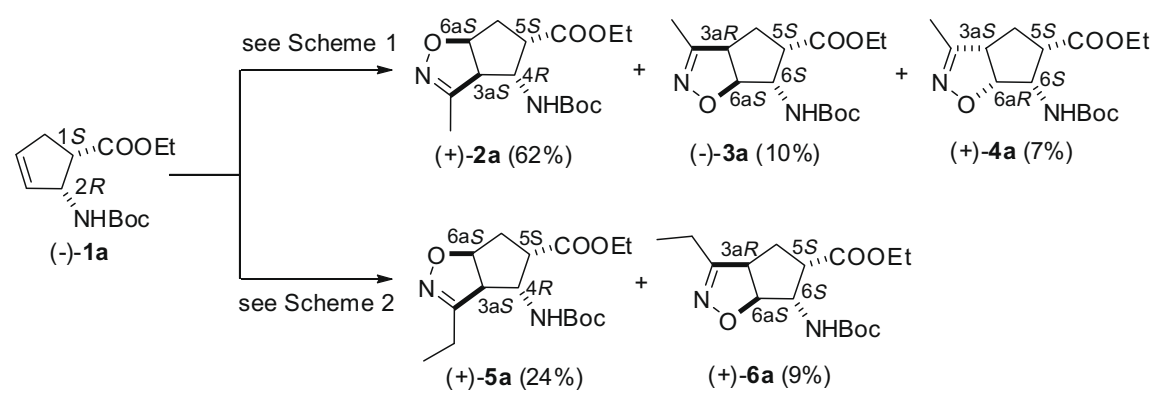

Scheme 3. Synthesis of the isoxazoline-fused ethyl $\beta$-aminocyclopentanecarboxylate enantiomers (+)-2a, (-)-3a, (+)-4a, (+)-5a, and (+)-6a.

\section{General procedure for the synthesis of isoxazoline-fused $\beta$ - aminocyclopentanecarboxylates}

To a solution of amino ester $\mathbf{1 a}-\mathbf{b}$ ( $3 \mathrm{mmol})$ in THF (20 mL), nitroalkane (3.2 mmol), DMAP $\left(0.6 \mathrm{mmol}, 20 \mathrm{~mol} \%\right.$ ), and $\mathrm{Boc}_{2} \mathrm{O}$ ( $9 \mathrm{mmol}, 3$ equiv) were added and the mixture was stirred at $20^{\circ} \mathrm{C}$ for $15 \mathrm{~h}$. The reaction mixture was then diluted with water $(50 \mathrm{~mL})$ and extracted with EtOAc $(3 \times 15 \mathrm{~mL})$. The combined organic layer was washed with $5 \% \mathrm{HCl}(15 \mathrm{~mL})$ and brine $(2 \times 20 \mathrm{~mL})$, dried $\left(\mathrm{Na}_{2} \mathrm{SO}_{4}\right)$ and concentrated under reduced pressure. The crude residue was purified by column chromatography on silica gel (hexane-EtOAc).

Characterization of enantiomeric products.

Ethyl (3aS,4R,5S,6aS)-4-(tert-butoxycarbonylamino)-3-methyl$\mathbf{4 , 5 , 6 , 6 a - t e t r a h y d r o - 3 a H - c y c l o p e n t a [ d ] i s o x a z o l e - 5 - c a r b o x y l a t e ~}$ [(+)-2a]

Yield: $62 \%$; white solid; $R_{\mathrm{f}}=0.65$ (hexane-EtOAc); $\mathrm{mp} 80-82{ }^{\circ} \mathrm{C}$; $[\alpha]_{\mathrm{D}}^{25}+10.9(c 0.34$, EtOH $)$, ee $>99 \% .{ }^{1} \mathrm{H}$ NMR $\left(400 \mathrm{MHz}, \mathrm{CDCl}_{3}\right)$ : $\delta=1.29\left(\mathrm{t}, 3 \mathrm{H}, \mathrm{CH}_{3}, J=7.15 \mathrm{~Hz}\right), 1.44\left(\mathrm{~s}, 9 \mathrm{H}, \mathrm{CH}_{3}\right), 2.08(\mathrm{~s}, 3 \mathrm{H}$, $\left.\mathrm{CH}_{3}\right), 2.23-2.39\left(\mathrm{~m}, 2 \mathrm{H}, \mathrm{CH}_{2}\right), 2.90-2.99(\mathrm{~m}, 1 \mathrm{H}, \mathrm{H}-5), 3.63-3.67$ $(\mathrm{m}, 1 \mathrm{H}, \mathrm{H}-3 \mathrm{a}), 4.13-4.22\left(\mathrm{~m}, 3 \mathrm{H}, \mathrm{OCH}_{2}\right.$ and $\left.\mathrm{H}-4\right), 5.06-5.11(\mathrm{~m}$, $1 \mathrm{H}, \mathrm{H}-6 \mathrm{a}), 5.22$ (br s, $1 \mathrm{H}, \mathrm{N}-\mathrm{H}) .{ }^{13} \mathrm{C}$ NMR (100 MHz, $\left.\mathrm{CDCl}_{3}\right)$ : $\delta=12.6,14.8,29.0,37.6,45.5,57.2,61.9,64.5,80.4,84.2,152.0$, 155.3, 155.8. MS: (ES, pos) $m / z=313(\mathrm{M}+1)$. Anal. Calcd for $\mathrm{C}_{15} \mathrm{H}_{24} \mathrm{~N}_{2} \mathrm{O}_{5}$ : C, 57.68; H, 7.77; N, 8.97. Found: C, 57.22; H, 7.45; $\mathrm{N}, 8.50$.
Ethyl (3aR,5S,6S,6aS)-6-(tert-butoxycarbonylamino)-3-methyl4,5,6,6a-tetrahydro-3aH-cyclopenta[d]isoxazole-5-carboxylate [(-)-3a]

Yield: $10 \%$; white solid; $R_{\mathrm{f}}=0.45$ (hexane-EtOAc); mp 104$106{ }^{\circ} \mathrm{C} ;[\alpha]_{\mathrm{D}}^{25}-7.5$ (c 0.41 , EtOH), ee $>99 \% .{ }^{1} \mathrm{H}$ NMR $(400 \mathrm{MHz}$, $\left.\mathrm{CDCl}_{3}\right): \delta=1.27\left(\mathrm{t}, 3 \mathrm{H}, \mathrm{CH}_{3}, J=7.15 \mathrm{~Hz}\right), 1.44\left(\mathrm{~s}, 9 \mathrm{H}, \mathrm{CH}_{3}\right), 1.95(\mathrm{~s}$, $\left.3 \mathrm{H}, \mathrm{CH}_{3}\right), 1.99-2.03\left(\mathrm{~m}, 1 \mathrm{H}, \mathrm{CH}_{2}\right), 2.25-2.33\left(\mathrm{~m}, 1 \mathrm{H}, \mathrm{CH}_{2}\right), 2.94-$ $2.98(\mathrm{~m}, 1 \mathrm{H}, \mathrm{H}-5), 3.63-3.67(\mathrm{~m}, 1 \mathrm{H}, \mathrm{H}-3 \mathrm{a}), 4.12-4.20(\mathrm{~m}, 2 \mathrm{H}$, $\left.\mathrm{OCH}_{2}\right), 4.28-4.30(\mathrm{~m}, 1 \mathrm{H}, \mathrm{H}-6), 4.89$ (br s, $\left.1 \mathrm{H}, \mathrm{N}-\mathrm{H}\right) .4 .90-4.94$ (m, 1H, H-6a). ${ }^{13} \mathrm{C}$ NMR (100 MHz, DMSO): $\delta=12.0,14.8,29.0$, 29.9, 46.3, 54.3, 60.5, 60.8, 79.0, 89.4, 155.0, 158.1, 171.7. MS: $(\mathrm{ES},+) m / z=647(2 \mathrm{M}+\mathrm{Na})$. Anal. Calcd for $\mathrm{C}_{15} \mathrm{H}_{24} \mathrm{~N}_{2} \mathrm{O}_{5}$ : C, 57.68; H, 7.77; N, 8.97. Found: C, 57.24; H, 7.43; N, 8.52.

Ethyl (3aS,5S,6S,6aR)-6-(tert-butoxycarbonylamino)-3-methyl$4,5,6,6 a-t e t r a h y d r o-3 a H$-cyclopenta[d]isoxazole-5-carboxylate $[(+)-4 a]$

Yield: $7 \%$; white solid; $R_{\mathrm{f}}=0.40$ (hexane-EtOAc); $\mathrm{mp} 82-85^{\circ} \mathrm{C}$; $[\alpha]_{\mathrm{D}}^{25}+430(c \quad 0.07, \mathrm{EtOH})$, ee $>99 \% .{ }^{1} \mathrm{H}$ NMR (400 MHz, DMSO): $\delta=1.18\left(\mathrm{t}, 3 \mathrm{H}, \mathrm{CH}_{3}, J=7.15 \mathrm{~Hz}\right), 1.41\left(\mathrm{~s}, 9 \mathrm{H}, \mathrm{CH}_{3}\right), 1.89-1.98(\mathrm{~m}$, $\left.1 \mathrm{H}, \mathrm{CH}_{2}\right), 2.00\left(\mathrm{~s}, 3 \mathrm{H}, \mathrm{CH}_{3}\right), 2.19-2.24\left(\mathrm{~m}, 1 \mathrm{H}, \mathrm{CH}_{2}\right), 2.97-3.05(\mathrm{~m}$, $1 \mathrm{H}, \mathrm{H}-5), 3.56-3.62(\mathrm{~m}, 1 \mathrm{H}, \mathrm{H}-3 \mathrm{a}), 3.92-4.05\left(\mathrm{~m}, 2 \mathrm{H}, \mathrm{OCH}_{2}\right)$, 4.10-4.15 (m, 1H, H-6), 4.78-4.83 (m, 1H, H-6a), 6.03 (br s, 1H, $\mathrm{N}-\mathrm{H}) .{ }^{13} \mathrm{C}$ NMR (100 MHz, DMSO): $\delta=11.9,14.7,28.6,29.0,44.5$, 54.2, 57.6, 60.9, 83.8, 155.6, 158.1, 172.1. MS (ES, +) $\mathrm{m} / \mathrm{z}=647$ $(2 \mathrm{M}+\mathrm{Na})$. Anal. Calcd for $\mathrm{C}_{15} \mathrm{H}_{24} \mathrm{~N}_{2} \mathrm{O}_{5}$ : C, 57.68; $\mathrm{H}, 7.77 ; \mathrm{N}, 8.97$. Found: C, 57.20; H, 7.46; N, 8.54. 
Ethyl (3aS,4R,5S,6aS)-4-(tert-butoxycarbonylamino)-3-ethyl$4,5,6,6 a-t e t r a h y d r o-3 a H$-cyclopenta[ $d]$ isoxazole-5-carboxylate $[(+)-5 a]$

Yield: 24\%; white solid; $R_{\mathrm{f}}=0.53$ (hexane-EtOAc); mp 105$107{ }^{\circ} \mathrm{C} ;[\alpha]_{\mathrm{D}}^{25}+2($ c 0.325 , EtOH $)$, ee $>99 \% .{ }^{1} \mathrm{H}$ NMR $(400 \mathrm{MHz}$, $\left.\mathrm{CDCl}_{3}\right): \delta=1.23\left(\mathrm{t}, 3 \mathrm{H}, \mathrm{CH}_{3}, J=8.20 \mathrm{~Hz}\right), 1.29\left(\mathrm{t}, 3 \mathrm{H}, \mathrm{CH}_{3}\right.$, $J=7.10 \mathrm{~Hz}), 1.44\left(\mathrm{~s}, 9 \mathrm{H}, \mathrm{CH}_{3}\right), 2.26-2.41\left(\mathrm{~m}, 3 \mathrm{H}, \mathrm{CH}_{2}\right), 2.50-2.56$ $\left(\mathrm{m}, 1 \mathrm{H}, \mathrm{CH}_{2}\right), 2.92-2.98(\mathrm{~m}, 1 \mathrm{H}, \mathrm{H}-5), 3.67-3.71(\mathrm{~m}, 1 \mathrm{H}, \mathrm{H}-3 \mathrm{a})$, 4.14-4.23 (m, 3H, $\mathrm{OCH}_{2}$ and $\left.\mathrm{H}-4\right), 5.05-5.11(\mathrm{~m}, 1 \mathrm{H}, \mathrm{H}-6 \mathrm{a}), 5.19$ (br s, $1 \mathrm{H}, \mathrm{N}-\mathrm{H}) .{ }^{13} \mathrm{C}$ NMR (100 MHz, DMSO): $\delta=11.5,14.8,20.5$, 28.9, 35.8, 46.9, 56.9, 60.8, 62.3, 78.9, 84.3, 155.5, 159.2, 171.6. MS $(E S,+) m / z=675(2 \mathrm{M}+\mathrm{Na})$. Anal. Calcd for $\mathrm{C}_{16} \mathrm{H}_{26} \mathrm{~N}_{2} \mathrm{O}_{5}$ : C, 58.88; H, 8.03; N, 8.58. Found: C, 58.48; H, 7.87; N, 8.20.

\section{Ethyl (3aR,5S,6S,6aS)-6-(tert-butoxycarbonylamino)-3-ethyl- $4,5,6,6 a-t e t r a h y d r o-3 \mathrm{a} H$-cyclopenta[d]isoxazole-5-carboxylate $[(+)-6 a]$}

Yield: 9\%; white solid; $R_{\mathrm{f}}=0.35$ (hexane-EtOAc); mp $78-81{ }^{\circ} \mathrm{C}$; $[\alpha]_{\mathrm{D}}^{25}+77$ (c 0.295, EtOH), ee $>99 \%$. ${ }^{1} \mathrm{H}$ NMR $(400 \mathrm{MHz}, \mathrm{DMSO})$ : $\delta=1.18(\mathrm{t}, 3 \mathrm{H}, J=7.10 \mathrm{~Hz}), 1.23(\mathrm{t}, 3 \mathrm{H}, J=7.15 \mathrm{~Hz}), 1.44(\mathrm{~s}, 9 \mathrm{H}$, $\left.\mathrm{CH}_{3}\right), 1.90-1.99\left(\mathrm{~m}, 1 \mathrm{H}, \mathrm{CH}_{2}\right), 2.18-2.41\left(\mathrm{~m}, 3 \mathrm{H}, \mathrm{CH}_{2}\right), 2.64-2.77$ (m, 1H, H-3a), 3.60-3.72 (m, 1H, H-5), 3.97-4.08 (m, 2H, OCH $\mathrm{OCH}_{2}$, 4.21-4.31 (m, 1H, H-6), 6.59-4.70 (m, 1H, H-6a), 7.08-7.17 (br s, $1 \mathrm{H}, \mathrm{N}-\mathrm{H}) .{ }^{13} \mathrm{C}$ NMR (100 MHz, DMSO): $\delta=11.4,14.8,20.0,29.0$, 30.1, 46.4, 53.1, 60.5, 60.8, 79.0, 89.4, 155.6, 162.2, 171.7. MS: $(\mathrm{ES},+) m / z=675(2 \mathrm{M}+\mathrm{Na})$. Anal. Calcd for $\mathrm{C}_{16} \mathrm{H}_{26} \mathrm{~N}_{2} \mathrm{O}_{5}$ : C, 58.88; H, 8.03; N, 8.58. Found: C, 58.51; H, 7.84; N, 8.12.

\section{X-ray crystallographic studies}

Crystallographic data for $\mathbf{2 b}, \mathbf{5 b}$, and $\mathbf{6 b}$ were collected at $173 \mathrm{~K}$ with a Nonius-Kappa CCD area detector diffractometer, using graphite-monochromatized MoK radiation $(\lambda=0.71073 \AA$ ). The structures were solved by direct methods by use of the SIR-97 program, and full-matrix, least-squares refinements on $\mathrm{F}^{2}$ were performed by use of the SHELXL-97 program. The $\mathrm{CH}$ hydrogen atoms were included at fixed distances with fixed displacement parameters from their host atoms. The NH hydrogen atoms were refined isotropically with fixed displacement parameters. The deposition numbers CCDC 707421 (2b), 707422 (5b), and 707423 (6b) contain the supplementary crystallographic data for this Letter. ${ }^{15}$

\section{Acknowledgment}

We are grateful to the Hungarian Research Foundation (OTKA Nos. F67970 and T049407) for financial support.

\section{References and notes}

1. (a) Khalil, M. A.; Maponya, M. F.; Ko, D. H.; You, Z.; Oriaku, E. T.; Lee, H. J. Med Chem. Res. 1996, 6, 52; (b) Fuller, A. A.; Chen, B.; Minter, A. R.; Mapp, A. K. J. Am. Chem. Soc. 2005, 127, 5376; (c) Bode, J. W.; Fraefel, N.; Muri, D.; Carreira, E. M. Angew. Chem., Int. Ed. 2001, 40, 2082; (d) Tangallapally, R. P.; Rakesh, D. S.; Budha, N.; Lee, R. E. B.; Lenaerts, A. J. M.; Meibohm, B.; Lee, R. E. Bioorg. Med. Chem. Lett. 2007, 17, 6638; (e) Sielecki, T. M.; Liu, J.; Mousa, S. A.; Racanelli, A.
L.; Hausner, E. A.; Wexler, R. R.; Olson, R. E. Bioorg. Med. Chem. Lett. 2001, 11, 2201.

2. (a) Lam, P. Y. S.; Adams, J. J.; Clark, C. G.; Calhoun, W. J.; Luettgen, J. M.; Knabb, R. M.; Wexler, R. R. Bioorg. Med. Chem. Lett. 2003, 13, 1795; (b) Barbachyn, M. R.; Cleek, G. J.; Dolak, L. A.; Garmon, S. A.; Morris, J.; Seest, E. P.; Thomas, R. C.; Toops, D. S.; Watt, W.; Wishka, D. G.; Ford, C. W.; Zurenko, G. E.; Hamel, J. C. Schaadt, R. D.; Stapert, D.; Yagi, B. H.; Adams, W. J.; Friis, J. M.; Slatter, J. G.; Sams, J. P.; Oien, N. L.; Zaya, M. J.; Wienkers, L. C.; Wynalda, M. A. J. Med. Chem. 2003, 46, 284; (c) Pirrung, M. C.; Tumey, L. N.; Raetz, C. R. H.; Jackman, J. E.; Snehalatha, K.; McClerren, A. L.; Fierke, C. A.; Gantt, S. L.; Rusche, K. M. J. Med. Chem. 2002, 45, 4359; (d) Quan, M. L.; Liauw, A. Y.; Ellis, C. D.; Pruitt, J. R.; Carini, D. J.; Bostrom, L. L.; Huang, P. P.; Harrison, K.; Knabb, R. M.; Thoolen, M. J.; Wong, P. C.; Wexler, R. R. J. Med. Chem. 1999, 42, 2752; (e) Gaonkar, S. L.; Rai, K. M. L.; Prabhuswamy, B. Med. Chem. Res. 2007, 15, 407; (f) Kozikowski, A. P.; Tapadar, S.; Luchini, D. N.; Kim, K. H.; Billadeau, D. D. J. Med. Chem. 2008, 51, 4370.

3. Kai, H.; Matsumoto, H.; Hattori, N.; Takase, A.; Fujiwara, T.; Sugimoto, H. Bioorg. Med. Chem. Lett. 2001, 11, 1997.

4. Basappa, M.; Sadashiva, P.; Mantelingu, K.; Swamy, N. S.; Rangappa, K. S. Bioorg Med. Chem. 2003, 11, 4539.

5. (a) Nair, V.; Suja, T. D. Tetrahedron 2007, 63, 12247; (b) Gothelf, K. V.; Jorgensen, K. A. Chem. Rev. 1998, 98, 863; (c) Gallos, J. K.; Koumbis, A. E. Curr. Org. Chem. 2003, 7, 397; (d) Pellisier, H. Tetrahedron 2007, 63, 3235; (e) Paswa, A. 1,3 Dipolar Cycloaddition Chemistry; Wiley: New York, 1984; (f) Kobayashi, S.; Jorgensen, K. A. Cycloaddition Reactions in Organic Synthesis; Wiley-VCH: Weinheim, 2002; (g) Torsell, K. B. G. Nitrile Oxides, Nitrones and Nitronates in Organic Synthesis; VCH: New York, 1988; (h) Namboothiri, I. N. N.; Rastogi, N.; Ganguly, B.; Mobin, S. M.; Cojocaru, M. Tetrahedron 2004, 60, 1453.

6. Christl, M.; Huisgen, R. Chem. Ber. 1973, 106, 3345.

7. Mukaiyama, T.; Hoshino, T. J. Am. Chem. Soc. 1960, 62, 5339.

8. (a) Pinto, A.; Conti, P.; De Amici, M.; Tamborini, L.; Grazioso, G.; Colleoni, S.; Mennini, T.; Gobbi, M.; De Micheli, C. Tetrahedron: Asymmetry 2008, 19, 867; (b) Conti, P.; Caligiuri, A.; Pinto, A.; Roda, G.; Tamborini, L.; Nielsen, B.; Madsen, U.; Frydenvang, K.; Colombo, A.; De Micheli, C. Eur. J. Med. Chem. 2007, 42, 1059; (c) Roda, G.; Conti, P.; De Amici, M.; He, J.; Polavaropu, P. L.; De Micheli, C. Tetrahedron: Asymmetry 2004, 15, 3079; (d) Conti, P.; De Amici, M.; Di Ventimiglia, S. J.; Stensbol, T. B.; Madsen, U.; Osborne, H. B.; Russo, E.; De Sarro, G.; Bruno, G.; De Micheli, C. J. Med. Chem. 2003, 46, 3102

9. Park, K. H.; Olmstead, M. M.; Kurth, M. J. Synlett 2003, 1267.

10. (a) Chand, P.; Bantia, S.; Kotian, P. L.; El-Kattan, Y.; Lin, T-H.; Babu, Y. S. Bioorg. Med. Chem. 2005, 13, 4071; (b) Chand, P.; Kotian, P. L.; Dehghani, A.; El-Kattan, Y.; Lin, T-H.; Hutchison, T. L.; Babu, Y. S.; Bantia, S.; Elliot, A. J.; Montgomery, J. A. J. Med. Chem. 2001, 44, 4379; (c) Mineno, T.; Miller, M. J. J. Org. Chem. 2003, 68,6591 .

11. (a) Quadrelli, P.; Piccanello, A.; Mella, M.; Corsaro, A.; Pistara, V. Tetrahedron 2008, 64, 3541; (b) Quadrelli, P.; Scrocchi, R.; Caramella, P.; Rescifina, A.; Piperno, A. Tetrahedron 2004, 60, 3643; (c) Quadrelli, P.; Piccanello, A.; Martinez, N. V.; Bovio, B.; Mella, M.; Caramella, P. Tetrahedron 2006, 62, 7370

12. (a) Fülöp, F. Chem. Rev. 2001, 101, 2181; (b) Mittendorf, J.; Kunisch, F.; Matzke, M.; Militzer, H-C.; Schmidt, A.; Schönfeld, W. Bioorg. Med. Chem. Lett. 2003, 13, 433; (c) Hamersak, Z.; Roje, M.; Avdagic, A.; Sunjic, V. Tetrahedron: Asymmetry 2007, 18, 635; (d) Hill, D. J.; Mio, M. J.; Prince, R. B.; Hughes, T. S.; Moore, J. S. Chem. Rev. 2001, 101, 3893; (e) Yang, D.; Zhang, D-W.; Hao, Y.; Wu, Y-D.; Luo S-W.; Zhu, N-Y. Angew. Chem., Int. Ed. 2004, 43, 6719; (f) Rathore, N.; Gellman, S. H.; Pablo, J. J. Biophys. J. 2006, 91, 3425.

13. (a) Cheng, R. P.; Gellman, S. H.; De Grado, W. F. Chem. Rev. 2001, 101, 3219; (b) Roy, O.; Faure, S.; Aitken, D. J. Tetrahedron Lett. 2006, 47, 5981; (c) Chandrasekhar, S.; Sudhakar, A.; Kiran, M. U.; Babu, B. N.; Jagadeesh, B. Tetrahedron Lett. 2008, 49, 7368; (d) Rua, F.; Boussert, S.; Parella, T.; Diez-Perez, I.; Branchadell, V.; Giralt, E.; Ortuno, R. M. Org. Lett. 2007, 9, 3643; (e) D’Elia, V.; Zwicknagl, H.; Reiser, O. J. Org. Chem. 2008, 73, 3262; (f) Hetényi, A.; Szakonyi, Z.; Mándity, I. M.; Szolnoki, É.; Tóth, G. K.; Martinek, T. A.; Fülöp, F. Chem Commun. 2009, 177; (g) Fülöp, F.; Martinek, T. A.; Tóth, G. K. Chem. Soc. Rev. 2006, 35, 323; (h) Martinek, T. A.; Tóth, G. K.; Vass, E.; Hollósi, M.; Fülöp, F. Angew. Chem., Int. Ed. 2002, 41, 1718; (i) Mándity, I. M.; Wéber, E.; Martinek, T. A.; Olajos, G.; Tóth, G. K.; Vass, E.; Fülöp, F. Angew. Chem., Int. Ed. 2009, 48, 2171.

14. (a) Forró, E.; Fülöp, F. Tetrahedron: Asymmetry 2004, 15, 2875-2880; (b) Kiss, L. Forró, E.; Sillanpää, R.; Fülöp, F. J. Org. Chem. 2007, 72, 8786.

15. The details of the crystallographic data for $\mathbf{2 b}, \mathbf{5 b}$, and $\mathbf{6 b}$ in CIF format can be obtained free of charge at www.ccdc.cam.ac.uk/conts/retrieving.html [or from the Cambridge Crystallographic Data Center, 12 Union Road, Cambridge CB2 1EZ, UK; Fax: (internat.) +44-1223-336-033; E-mail: deposit@ccdc.cam.ac.uk]. 
II. 


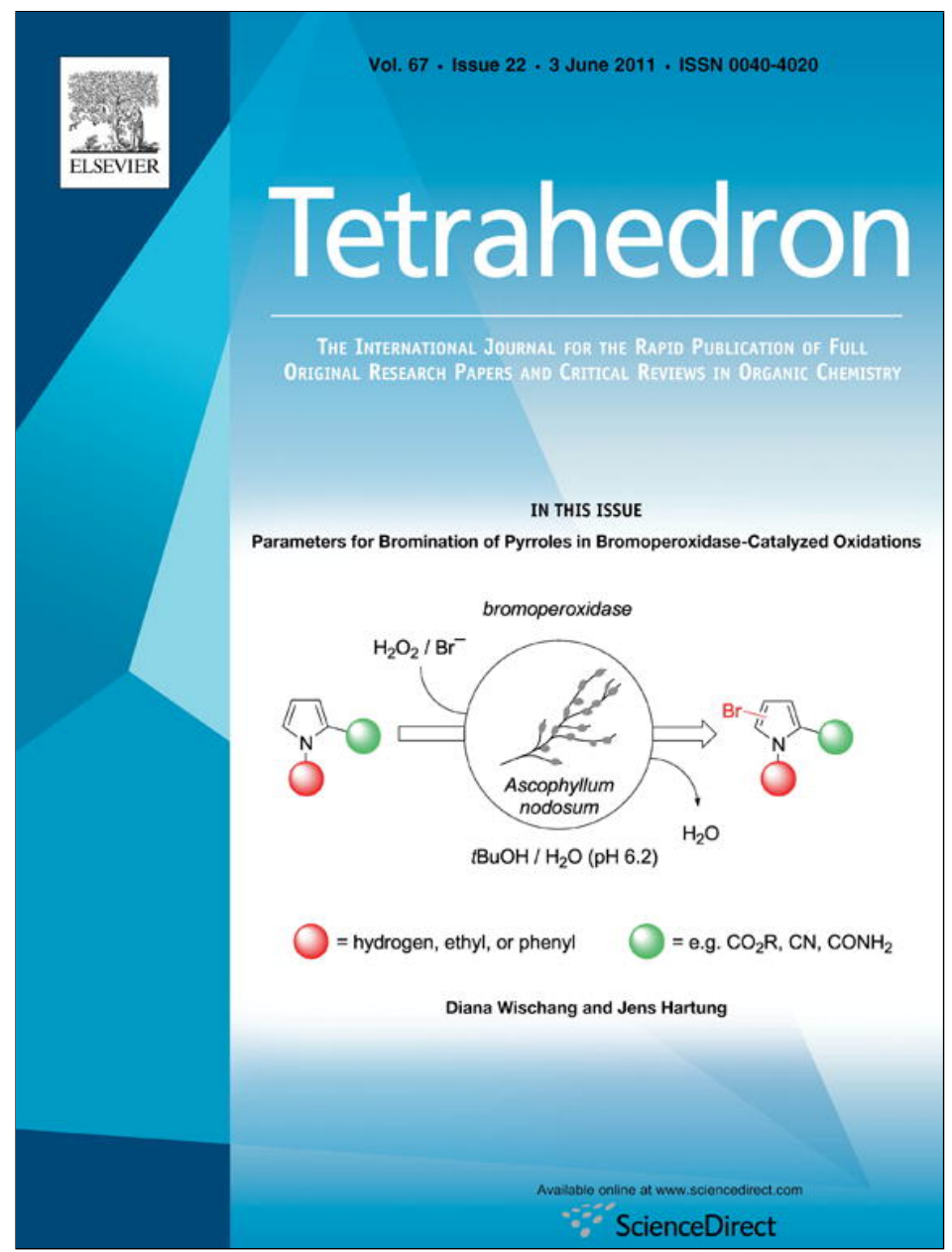

This article appeared in a journal published by Elsevier. The attached copy is furnished to the author for internal non-commercial research and education use, including for instruction at the authors institution and sharing with colleagues.

Other uses, including reproduction and distribution, or selling or licensing copies, or posting to personal, institutional or third party websites are prohibited.

In most cases authors are permitted to post their version of the article (e.g. in Word or Tex form) to their personal website or institutional repository. Authors requiring further information regarding Elsevier's archiving and manuscript policies are encouraged to visit:

http://www.elsevier.com/copyright 


\title{
Synthesis of novel isoxazoline-fused cyclic $\beta$-amino esters by regio- and stereo- selective 1,3-dipolar cycloaddition
}

\author{
Melinda Nonn ${ }^{\mathrm{a}}$, Loránd Kiss ${ }^{\mathrm{a}}$, Enikő Forró ${ }^{\mathrm{a}}$, Zoltán Mucsi ${ }^{\mathrm{c}}$, Ferenc Fülöp ${ }^{\mathrm{a}, \mathrm{b}, *}$ \\ ${ }^{a}$ Institute of Pharmaceutical Chemistry, University of Szeged, H-6720 Szeged, Eötvös u. 6, Hungary \\ ${ }^{\mathrm{b}}$ Research Group of Stereochemistry of the Hungarian Academy of Sciences, University of Szeged, H-6720 Szeged, Eötvös u. 6, Hungary \\ ${ }^{\mathrm{c}}$ Department of Chemical Informatic, University of Szeged, H-6725 Szeged, Hungary
}

\section{A R T I C L E I N F O}

Article history:

Received 24 January 2011

Received in revised form 21 March 2011

Accepted 4 April 2011

Available online 9 April 2011

\begin{abstract}
A B S T R A C T
Isoxazoline-fused 2-aminocyclopentanecarboxylate derivatives were regio- and stereo-selectively synthesized by nitrile oxide 1,3-dipolar cycloaddition to cis- or trans-ethyl-2-aminocyclopent-3-enecarboxylates. The compounds were prepared in enantiomerically pure form by enzymatic resolution of the racemic bicyclic $\beta$-lactam.
\end{abstract}

(c) 2011 Elsevier Ltd. All rights reserved.

\section{Introduction}

The 1,3-dipolar cycloaddition of nitrile oxides to alkenes has become widely used as a highly efficient method for the synthesis of isoxazolines. ${ }^{1}$ Nitrile oxides can be generated in situ by either the base-induced dehydrohalogenation of hydroximoyl chlorides (methodology of Huisgen ${ }^{2}$ ), or the dehydration of primary nitroalkane derivatives (methodology of Mukaiyama ${ }^{3}$ ). The 1,3-dipolar cycloaddition of nitrile oxides is a powerful technique to functionalize olefins since the isoxazoline ring formed may be regarded as a masked iminoalcohol, hydroxyketone or aminoalcohol. ${ }^{1}$ A number of nitrile oxide cycloadditions to cyclic $\alpha$ - or $\gamma$-amino acid derivatives have been performed in recent years with the aim of the synthesis of different biologically active compounds. For example, isoxazole carboxylic acids, such as conformationally constrained aspartate and glutamate analogues have been synthesized via addition to $\alpha$-amino cyclopentene esters. ${ }^{4}$ The derivatives prepared proved to be inhibitors of excitatory amino acid transporters with neuroprotective activity. ${ }^{4}$ Cycloaddition to $\gamma$-amino cyclopentene acids was applied for the stereoselective synthesis of novel multisubstituted cyclopentene derivatives, which were described as antiviral agents. ${ }^{5}$ A novel route to isoxazoline/carbocyclic nucleosides involved the regio- and stereo-selective 1,3-dipolar cycloaddition of nitrile oxides to 2-azanorbornenes, followed by ring opening and a purine or pyrimidine base construction strategy. ${ }^{6}$ Alicyclic $\beta$-amino acids have acquired great interest in recent years because of their pharmacological potential. ${ }^{7}$ The naturally occurring $\beta$-amino acid cispentacin (1R,2S-2-aminocyclopentanecarboxylic acid), an antibiotic and $(1 R, 2 S)-2$-amino-4-methylenecyclopentane-carboxylic acid (Icofungipen), a strong antifungal agent, for instance, are important

\footnotetext{
* Corresponding author. E-mail address: fulop@pharm.u-szeged.hu (F. Fülöp).
}

examples of this class of compounds. ${ }^{7}$ A number of cyclic, conformationally restricted $\beta$-amino acids have been used as building blocks for the synthesis of new peptides. ${ }^{8}$

\section{Results and discussion}

We recently reported novel isoxazoline-fused cispentacin regioand stereo-isomers via a strategy of 1,3-dipolar cycloaddition of nitrile oxides to protected cis-2-aminocyclopent-3-ene carboxylates. ${ }^{9}$ The nitrile oxides were generated from primary nitroalkanes $\left(\mathrm{RNO}_{2}\right)$ in the presence of tert-butoxycarbonyl anhydride $\left(\mathrm{Boc}_{2} \mathrm{O}\right)$ and 4-dimethylaminopyridine (DMAP) according to the methodology of Mukaiyama. The cycloadditions to cis-amino esters $\mathbf{1}$ resulted in three of the four possible regio- and stereo-isomers $\mathbf{2 , 3}$ and 4. Although the cycloaddition was not selective, three isoxazoline-fused cispentacin derivatives $\mathbf{2}, \mathbf{3}$ and $\mathbf{4}$ could be isolated (Scheme 1).

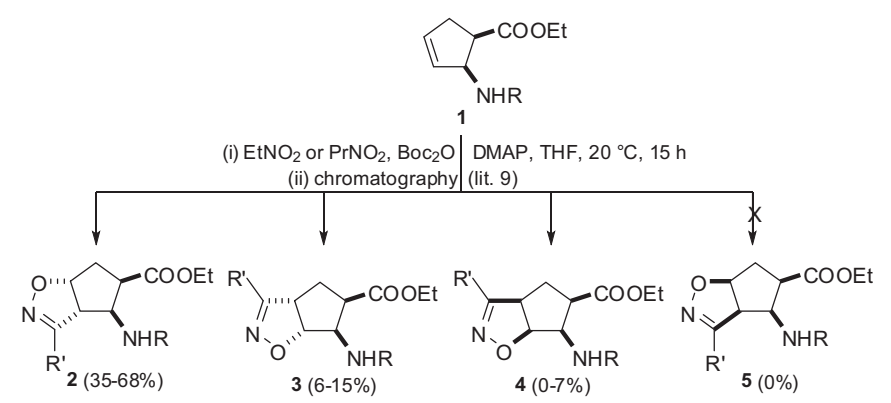

Scheme 1. Synthesis of isoxazoline-fused $\beta$-amino esters from cis-2-aminocyclopentenecarboxylates $\mathbf{1}\left(\mathrm{R}=\mathrm{Boc}, \mathrm{COPh} ; \mathrm{R}^{\prime}=\mathrm{Me}, \mathrm{Et}\right)^{9}$. 
Since the above procedure was not selective, we continued our experiments to search for other synthetic routes for the preparation of isoxazoline-fused cispentacins with higher selectivity. Dehydration of primary nitroalkanes to generate nitrile oxides may be accomplished not only with $\mathrm{Boc}_{2} \mathrm{O}$ and DMAP (Scheme 1), but also with phenyl isocyanate ( $\mathrm{PhNCO}$ ) and triethylamine $\left(\mathrm{Et}_{3} \mathrm{~N}\right)$. Compounds 1a,b were subjected to 1,3-dipolar cycloaddition under these conditions, using $\mathrm{RNO}_{2}, \mathrm{PhNCO}, \mathrm{Et}_{3} \mathrm{~N}$ in THF at $65{ }^{\circ} \mathrm{C}$ (Scheme 2).
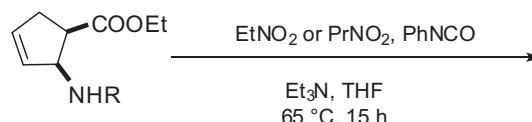

$65^{\circ} \mathrm{C}, 15 \mathrm{~h}$

1a: $R=B o c$

$1 \mathrm{~b}: \mathrm{R}=\mathrm{COPh}$

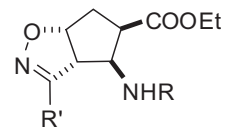

2a: $\mathrm{R}=\mathrm{Boc} ; \mathrm{R}^{\prime}=\mathrm{Me} ; 50 \%$ 2b: R = COPh; R' = Me; $38 \%$ 2c: $R=$ Boc; $R^{\prime}=E t ; 30 \%$ 2d: $R=C O P h ; R^{\prime}=E t ; 40 \%$

Scheme 2. Regio- and stereo-selective synthesis of isoxazoline-fused $\beta$-amino esters 2a-d from cis-2-aminocyclopentenecarboxylates 1a,b.

The reactions with the nitrile oxides derived from $\mathrm{EtNO}_{2}$ or $\mathrm{PrNO}_{2}$ in the presence of PhNCO resulted selectively in $\mathbf{2 a}-\mathbf{d}$, in which the isoxazoline ring is trans to the carbamate and ester groups, and the $O$-atom of the isoxazoline skeleton is farthest from the carbamate (Scheme 2). The explanation of the unexpected selectivity in this reaction is not yet clear. We are not aware of any similar example in the literature.

To clarify matters, DFT calculations ${ }^{10}$ were carried out on the reaction of 1 and MeNCO by using the $\mathrm{GO}^{11}$ program; the reaction enthalpies and Gibbs free energies of the transition states $\left(\Delta H^{\ddagger}\right.$; $\left.\Delta G^{\ddagger}\right)$ and products $(\Delta H ; \Delta G)$ are listed in Table 1 . Surprisingly, from a kinetic aspect, $\mathbf{4}$ was predicted to be the main product of the reaction, due to its lowest activation Gibbs free energy $\left(\Delta G^{\ddagger}\right)$. Compounds $\mathbf{2}$ and $\mathbf{5}$ exhibited practically equal $\Delta G^{\ddagger}$ values, but the significantly higher energies (ca. $4 \mathrm{~kJ} \mathrm{~mol}^{-1}$ ) suggest predicted concentrations of only a few per cent. The formation of $\mathbf{3}$ is least favourable, its formation being practically hindered. A possible explanation of the lowest-energy transition state of $\mathbf{4}$ is an intermolecular $\mathrm{H}$-bond ( $\mathrm{HB}$ ) between $\mathrm{MeNCO}$ and the amide in $\mathbf{1}$, as shown in Fig. 1. The same results were obtained at each level of computation $[\mathrm{HF} / 3-21 \mathrm{G}, \quad \mathrm{B} 3 \mathrm{LYP} / 6-31 \mathrm{G}(\mathrm{d}, \mathrm{p})$ and B3LYP/6$311++G(2 d, 2 p)]$, irrespective of the solvent models applied [IEFPCM(THF)], and the theoretical model was therefore extended to a more complex description. It was earlier demonstrated that an explicit consideration of some selected solvent molecules or other components in the solvent provided a much more accurate picture of the mechanism. ${ }^{12}$ In this particular case, the solvent is THF, which does not require the exact consideration of any THF molecule. However, excess $\mathrm{EtNO}_{2}$ can be regarded as a cosolvent, strongly $\mathrm{H}$-bonded to the amide in $\mathbf{1}$. When the study of the ring closure mechanism included one explicit $\mathrm{EtNO}_{2}$, the result altered. The lowest $\Delta G^{\ddagger}$ was computed for $\mathbf{2}$ (Fig. 1), but the value for $\mathbf{3}$ was very close, in agreement with experiment, where $\mathbf{3}$ was also detected in a significant amount beside the main component (2). For $\mathbf{4}$ and $\mathbf{5}$, the $\Delta G^{\ddagger}$ values were in all cases higher than those calculated in vacuo, because the nitro compound occupied the reactive zone to some extent and hinders the attack of MeNCO (Fig. 1).
The result of cycloaddition of the nitrile oxide to trans-2-aminocyclopentenecarboxylate $\mathbf{6 a}, \mathbf{b}$ proved interesting (Scheme 3). Whereas the addition to the corresponding cis isomer ( $\mathbf{1})$ gave the three isomers $\mathbf{2}, \mathbf{3}$ and $\mathbf{4}$ (Scheme 1), under the same experimental conditions $\left(\mathrm{RNO}_{2}, \mathrm{Boc}_{2} \mathrm{O}\right.$ and DMAP) the trans counterparts $\mathbf{6 a}, \mathbf{b}$ furnished selectively only one cycloadduct isomer ( $\mathbf{7 a}-\mathbf{d}$ ) (Scheme 3 ). Compounds $7 \mathbf{a}-\mathbf{d}$ could also be prepared by the epimerization of $\mathbf{4 a}-\mathbf{c}$ at $\mathrm{C}-5$ in the presence of NaOEt in $\mathrm{EtOH}, \mathbf{4 a}-\mathbf{c}$ were prepared as very minor isomers by cycloaddition to $\mathbf{1}$ (Scheme 1 ).

The selectivity of formation of $\mathbf{7 a}-\mathbf{d}$ from $\mathbf{6 a}, \mathbf{b}$ is probably explained by: steric and $\mathrm{H}$-bonding interactions, as presented in Fig. 2, i.e, steric repulsion in the transition state (T7) between the nitrile oxide and the ester group and an H-bonding interaction between the carbamate and the nitrile oxide (Scheme 3, Fig. 2). ${ }^{4 \mathrm{~d}}$

The stereoselectivity in the reaction of $\mathbf{1}$ with the nitrile oxides (generated from $\mathrm{RNO}_{2}$ and $\mathrm{Boc}_{2} \mathrm{O}$; Scheme 1) can probably be explained analogously. Steric repulsion between the ester moiety and the nitrile oxide determines the stereochemistry of $\mathbf{2}$ and $\mathbf{3}$ (Fig. 2). H-bonding interaction between the nitrile oxide and carbamate (cis to -COOEt) may be neglected in these cases (T2 and T3). The regioselectivity is probably determined by the electronwithdrawing effect of the $\mathrm{N}$-atom of the -NHBoc group, favouring attack of the nitrile oxide $O$-atom on $\mathrm{C}-4$, distant from the carbamate. These two phenomena lead to the major products 2 and 3 (Scheme 1). Formation of the very minor product $\mathbf{4}$ is an indication that the $\mathrm{H}$-bonding interaction between the carbamate and nitrile oxide in transition state can just overcome the ester/ nitrile oxide steric repulsion (Fig. 2). The regioselectivity of the formation of $\mathbf{4}$ may also be explained on the basis of $\mathrm{H}$-bonding interactions. The postulated transition state $\mathbf{T 5}$, which would lead to the fourth possible isomer in this reaction, involves highly unfavourable steric hindrance not only between the ester and the nitrile oxide, but also between the carbamate and the alkyl moiety (R) of the nitrile oxide. This explains why isomer 5 was never formed (Fig. 3, Scheme 1).

The results of calculations at different levels [B3LYP/6$31++\mathrm{G}(\mathrm{d}, \mathrm{p}), \mathrm{B} 3 \mathrm{LYP} / 6-311++\mathrm{G}(\mathrm{d}, \mathrm{p})$ and B3LYP/6-311++G(2d,2p)] relating to interpretation of the selectivity agreed well with the experimental finding that preferred product in the transformation of $\mathbf{6 b}$ was $\mathbf{7 b}$ (Table 2, Fig. 4).

These computations furnished eloquent proof that the selectivity of nitrile oxide addition to trans-2-aminocyclopentenecarboxylate is largely determined by the $\mathrm{H}$-bonding effect in the transition state (Fig. 5).

The earlier synthesized isoxazoline-fused cispentacin derivatives (Scheme 1$)^{9}$ afforded an opportunity for the preparation of new transpentacin derivatives, regio- and stere-oisomers of 7. Accordingly, 2a-d and 3a-d were epimerized at C-5 with NaOEt in EtOH to give izoxazoline-fused amino esters $8 \mathbf{a}-\mathbf{d}$ and $\mathbf{9 a}-\mathbf{d}$, in which the amino and carboxylate functions were trans. Unfortunately, the yields were low and a relatively large amount of starting material was recovered during column chromatography purification of the products (Scheme 4).

The 100\% regio- and stereo-selective synthesis of $\mathbf{2 a}$ and $\mathbf{2 c}$ (Scheme 2) and $\mathbf{7 a}$ and $\mathbf{7 c}$ (Scheme 3) was extended to their preparation in enantiomerically pure form. The starting material

Table 1

Enthalpy (in $\mathrm{kJ} \mathrm{mol}^{-1}$ ) and Gibbs free energy (in $\mathrm{kJ} \mathrm{mol}^{-1}$ ) of the transformation of $\mathbf{1 b}$ to $\mathbf{2} \mathbf{b}-\mathbf{5 b}$ in vacuo, with implicit solvent and with explicit solvent model

\begin{tabular}{|c|c|c|c|c|c|c|c|c|c|c|c|c|}
\hline & \multicolumn{4}{|c|}{ In vacuo } & \multicolumn{4}{|c|}{ In implicit solvent (THF) } & \multicolumn{4}{|c|}{ With explicit cosolvent } \\
\hline & $\Delta H^{\ddagger}$ & $\Delta G^{\ddagger}$ & $\Delta H$ & $\Delta G$ & $\Delta H^{\ddagger}$ & $\Delta G^{\ddagger}$ & $\Delta H$ & $\Delta G$ & $\Delta H^{\ddagger}$ & $\Delta G^{\ddagger}$ & $\Delta H$ & $\Delta G$ \\
\hline $2 \mathbf{b}$ & 55.8 & 114.1 & -169.5 & -104.3 & 59.1 & 118.2 & -165.7 & -100.0 & 67.3 & 126.1 & -164.1 & -100.1 \\
\hline 3b & 75.1 & 128.3 & -159.1 & -97.2 & 79.3 & 132.5 & -154.1 & -92.0 & 70.1 & 129.3 & -153.4 & -92.0 \\
\hline $4 b$ & 49.8 & 109.5 & -164.1 & -101.5 & 54.2 & 113.8 & -160.3 & -98.1 & 75.8 & 135.5 & -160.2 & -97.7 \\
\hline $5 \mathbf{b}$ & 54.9 & 113.7 & -166.7 & -100.9 & 58.2 & 117.9 & -161.9 & -96.3 & 95.4 & 153.9 & -161.3 & -96.5 \\
\hline
\end{tabular}


in vacuo or implicit solvent model:

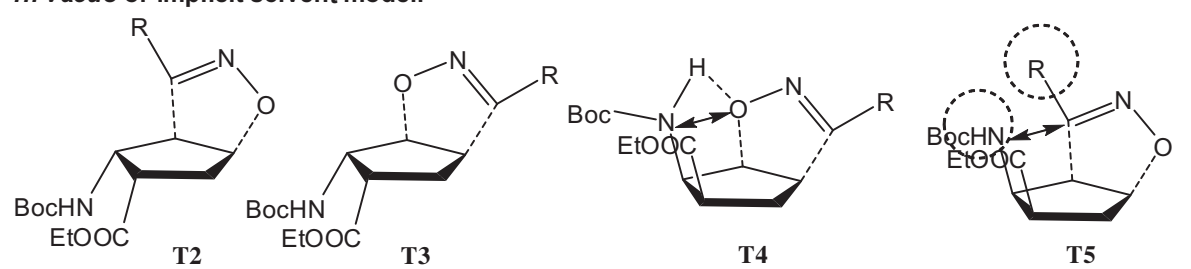

explicit solvent model:

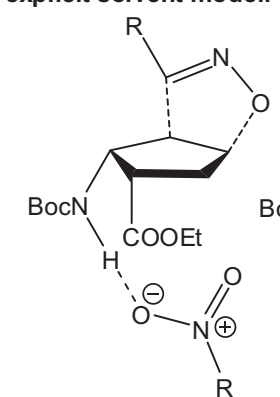

T2'

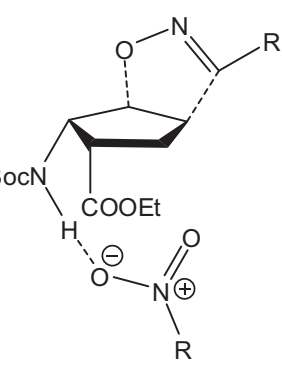

T3'

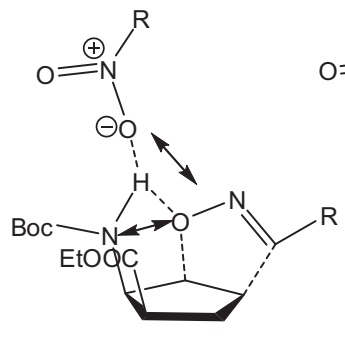

T4'

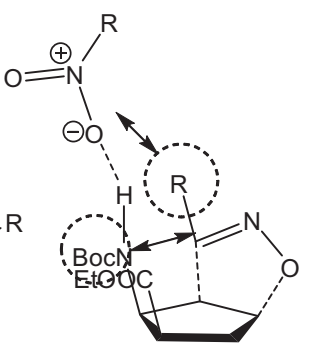

T5

Fig. 1. Transition states T2, T3 and $\mathbf{T} 4$ in the formation of cycloadducts $\mathbf{2}-\mathbf{5}$; steric repulsions between - COOEt and nitrile oxides in $\mathbf{T} 2$ and $\mathbf{T 3}$, and between - NHBoc and nitrile oxide and -COOEt and nitrile oxide in $\mathbf{T 5}$ and hydrogen bonding interaction between - NHBoc and nitrile oxide in $\mathbf{T 4}$.

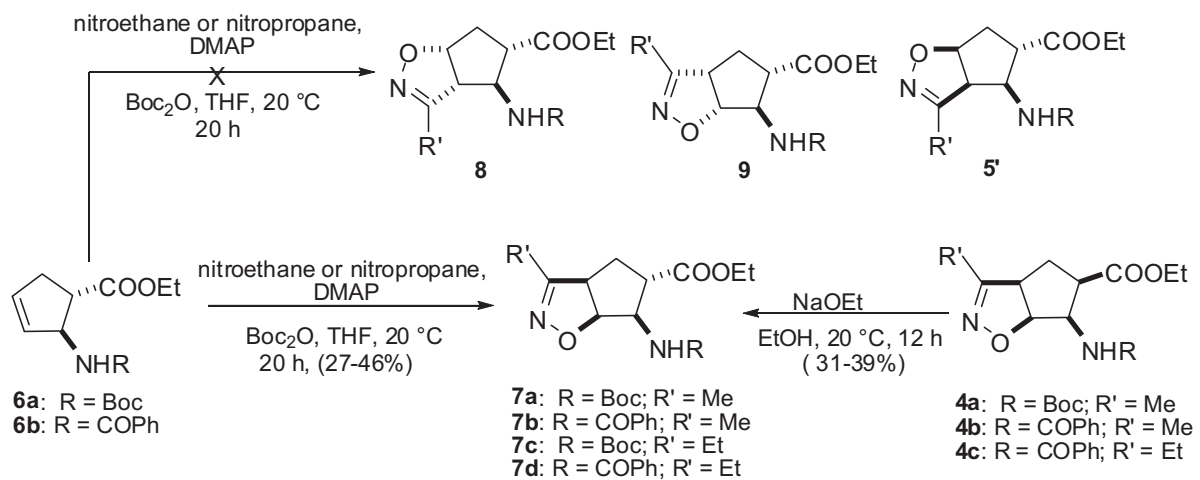

Scheme 3. Regio- and stereo-selective synthesis of isoxazoline-fused $\beta$-amino esters $\mathbf{7 a - d}$ from trans-2-aminocyclopentenecarboxylates $\mathbf{6 a , b}$.

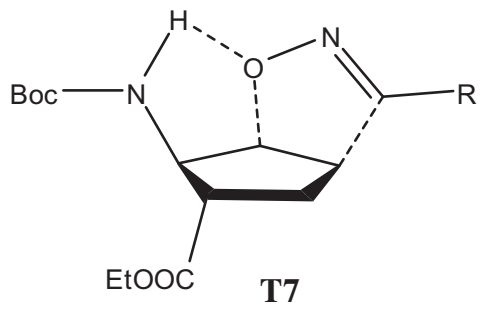

Fig. 2. Transition state $\mathbf{T 7}$ stabilized by hydrogen bonding interactions during formation of cycloadducts $\mathbf{7 a}-\mathbf{d}$. the racemic bicyclic lactam $\mathbf{1 0}$ was subjected to enzymatic ring opening reaction with Lipolase in $i-\operatorname{Pr}_{2} \mathrm{O},{ }^{13}$ which afforded the desired amino acid enantiomer $(+)-\mathbf{1 1}$ in excellent enantiomeric excess (ee >99\%). ${ }^{14}$ Compound $(+)-\mathbf{1 1}$ was then transformed by known procedures to the corresponding protected amino ester $(+)-\mathbf{1 a} .^{15}$ Compound (+)-1a was next submitted to nitrile oxide (generated from $\mathrm{EtNO}_{2}$ or $\mathrm{PrNO}_{2}$ and $\mathrm{PhNCO}$ and $\mathrm{Et}_{3} \mathrm{~N}$ ) cycloaddition, which resulted in the enantiomerically pure isoxazoline-fused cispentacin derivatives (-)-2a and (-)-2c in yield of $53 \%$ and $40 \%$ (Scheme 5).

Compounds (-)-2a and (-)-2c were epimerized in the presence of NaOEt in EtOH to the enantiomerically pure isoxazoline-fused transpentacin derivatives (+)-8a and (+)-8c (Scheme 5).

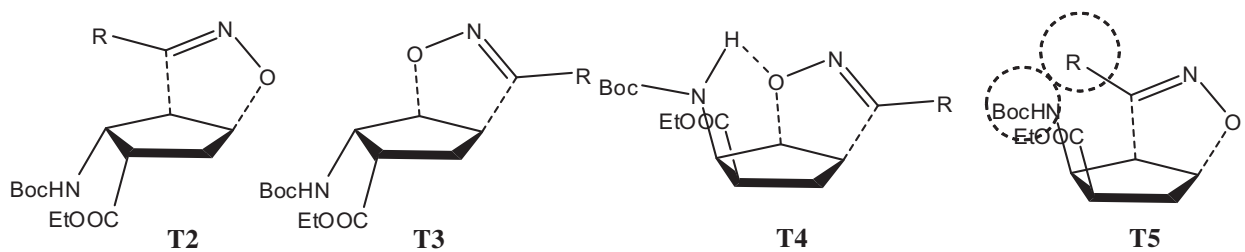

Fig. 3. Transition states T2, T3 and $\mathbf{T} 4$ in the formation of cycloadducts $\mathbf{2}-\mathbf{5}$; steric repulsions between - COOEt and nitrile oxides in $\mathbf{T} \mathbf{2}$ T3 and between $-\mathrm{NHBoc}$ and the nitrile oxide and between -COOEt and the nitrile oxide in $\mathbf{T 5}$ and H-bonding interaction between - NHBoc and the nitrile oxide in $\mathbf{T 4}$. 
Table 2

Enthalpy (in kJ mol${ }^{-1}$ ) and Gibbs free energy (in kJ mol${ }^{-1}$ ) of the transformation of $6 \mathbf{b}$ to $7 \mathbf{b}, 8 \mathbf{b}, 9 \mathbf{b}$ and $\mathbf{5}^{\prime} \mathbf{b}$

\begin{tabular}{llllll}
\hline & $\mathbf{6 b} \rightarrow \mathbf{T S}$ & & & $\mathbf{6 b} \rightarrow$ products & \\
\cline { 2 - 3 } & $\Delta \mathrm{H}^{\neq}$ & $\Delta G^{\neq}$ & & $\Delta H$ & $\Delta G$ \\
\hline $\mathbf{7 b}$ & 47.76 & 102.21 & & -170.02 & -106.24 \\
$\mathbf{8 b}$ & 65.32 & 119.90 & & -154.35 & -92.50 \\
$\mathbf{9 b}$ & 76.83 & 130.31 & & -152.22 & -90.46 \\
$\mathbf{5} \mathbf{b}$ & 55.36 & 113.99 & -163.44 & -100.12 \\
\hline
\end{tabular}

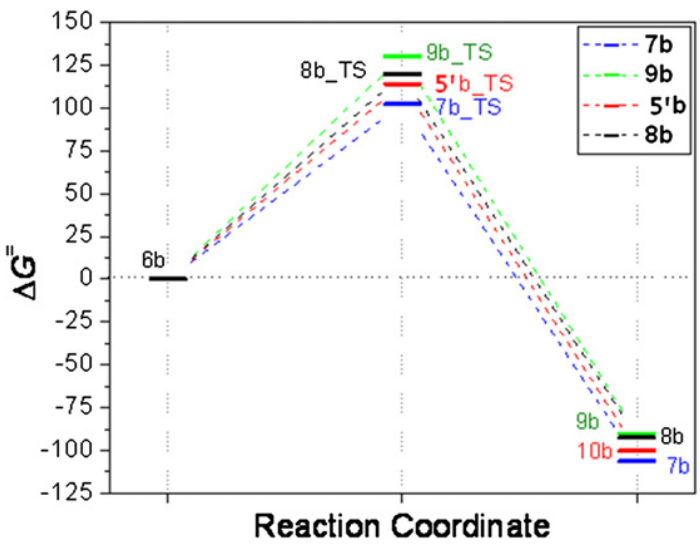

Fig. 4. Energy diagram for the transformation of $\mathbf{6 b}$ to $\mathbf{7 b}$
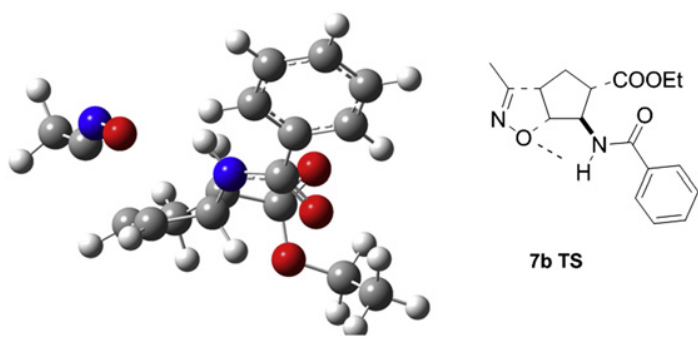

$7 \mathrm{~b}$ TS

Fig. 5. H-bonding stabilization of $\mathbf{T S} \mathbf{7 b}$ in the formation of $\mathbf{7 b}$<smiles></smiles>

8a: $R=$ Boc; $R^{\prime}=$ Me; $75 \%$ 8b: $\mathrm{R}=\mathrm{COPh} ; \mathrm{R}^{\prime}=\mathrm{Me} ; 37 \%$ $8 c:$ R = Boc; $R^{\prime}=$ Et; $30 \%$ 8d: $R=C O P h ; R^{\prime}=E t ; 45 \%$<smiles>[R]NC1[C@H](C(=O)OCC)C[C@@H]2C([R])=NO[C@@H]12</smiles>

9a: $R=$ Boc; $R^{\prime}=M e ; 20 \%$ 9b: $R=$ COPh; R' = Me; $30 \%$ 9c: $R=$ Boc; $R^{\prime}=$ Et; $28 \%$ 9d: $R=C O P h ; R^{\prime}=E t ; 10 \%$

Scheme 4. Synthesis of isoxazoline-fused $\beta$-amino esters $8 \mathbf{a}-\mathbf{d}$ and $\mathbf{9 a}-\mathbf{d}$ by epimerization of $\mathbf{2} \mathbf{a}-\mathbf{d}$ and $\mathbf{3 a}-\mathbf{d}$.

Boc-protected amino ester $(+)-\mathbf{1 a}$ was isomerized to its trans derivative $(+)-6 a$, which was then subjected to nitrile oxide (generated from $\mathrm{EtNO}_{2}$ or $\mathrm{PrNO}_{2}$ and $\mathrm{Boc}_{2} \mathrm{O}$ and $\mathrm{Et}_{3} \mathrm{~N}$ ) cycloaddition, giving the enantiomerically enriched isoxazoline-fused cispentacin derivatives (+)-7a and (+)-7c in yield of 52\% and 34\% (Scheme 6).

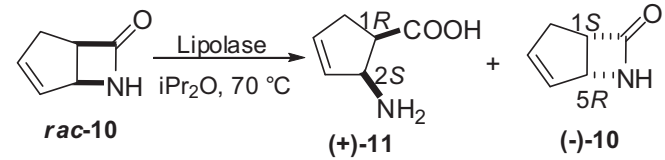

1. $\mathrm{SOCl}_{2}, \mathrm{EtOH}, 70^{\circ} \mathrm{C}, 3 \mathrm{~h}$

2. $\mathrm{Boc}_{2} \mathrm{O}, \mathrm{Et} 3 \mathrm{~N}, \mathrm{THF}, \mathrm{O}^{\circ} \mathrm{C}$ to $20^{\circ} \mathrm{C}$

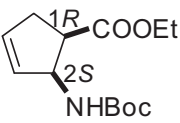

$(+)-1 \mathrm{a}$

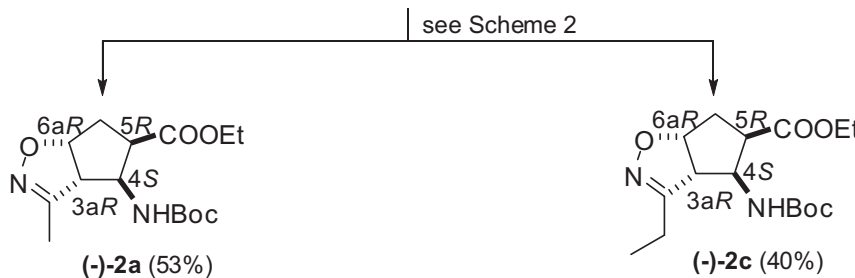

$(-)-2 a(53 \%)$

NaOEt, EtOH, $20^{\circ} \mathrm{C}$

$\checkmark 12 \mathrm{~h}, 22 \%$

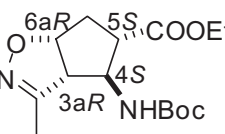

$(+)-8 a$

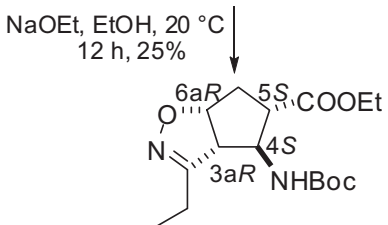

$(+)-8 c$
Scheme 5. Synthesis of the isoxazoline-fused $\beta$-amino ester enantiomers (-)-2a $(-)-\mathbf{2 c},(+)-\mathbf{8 a}$ and $(+)-\mathbf{8 c}$.

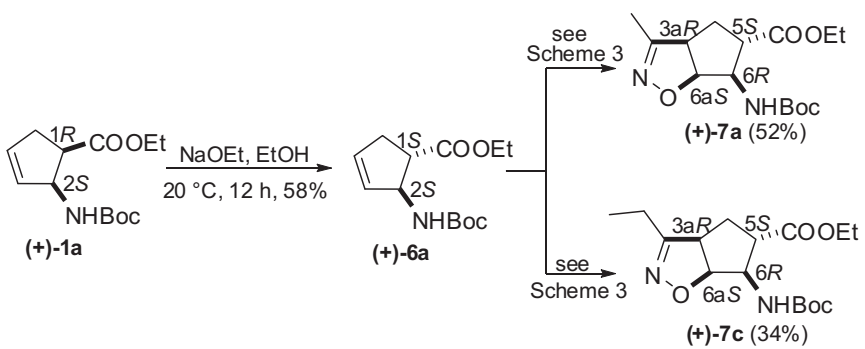

Scheme 6. Synthesis of the isoxazoline-fused $\beta$-amino ester enantiomers ( +$)-\mathbf{7 a}$ and (+)-7c.

In conclusion, isoxazoline-fused cispentacin derivatives were synthesized regio- and stereo-selectively via the 1,3-dipolar cycloaddition of nitrile oxides to cis- and trans-ethyl 2-amino-3cyclopentenecarboxylates. This synthetic pathway was also applied for the preparation of these compounds in enantiomerically pure form.

\section{Experimental}

\subsection{General}

The chemicals were purchased from Aldrich. Melting points were determined with a Kofler apparatus. NMR spectra were recorded on a Bruker DRX 400 spectrometer. Chemical shifts are given in parts per million relative to TMS as internal standard, with $\mathrm{CDCl}_{3}$ or DMSO as solvent. The solvents were used as received from the supplier. Optical rotations were measured with a Perkin-Elmer 341 polarimeter. Mass spectra were recorded on a Finnigan MAT 95S spectrometer. Elemental analyses were performed with a Perkin-Elmer CHNS-2400 Ser II Elemental Analyzer.

The ee values for $(-)-\mathbf{2 a},(+)-\mathbf{1 4 a}$ and $(+)-\mathbf{7 a}$ were determined by GC on a Chromopack Chiralsil-Dex CB column $(25 \mathrm{~m})$ [ $190{ }^{\circ} \mathrm{C}$; 
$140 \mathrm{kPa}$; retention times (min): (-)-2a: 19.82 (antipode: 20.02); (+)-7a: 16.99 (antipode: 15.79); (+)-8a: 19.46 (antipode: 20.01)], while ee for (-)-2c was determined by GC on a CP-Chiralsil L-Val column $(25 \mathrm{~m})\left[190^{\circ} \mathrm{C} ; 100 \mathrm{kPa}\right.$; retention time (min): 17.61 (antipode: 17.86)]. The ee value for (+)-7c was determined by HPLC on a Chiralcel ${ }^{\mathrm{R}}$ OD $5 \mu$ column $(0.46 \mathrm{~cm} \times 25 \mathrm{~cm})$ [mobile phase: $n$ hexane/2-propanol (95:5); flow rate $5 \mathrm{~mL} \mathrm{~min}^{-1}$; detection at $205 \mathrm{~nm}$; retention time (min): 25.06 (antipode: 32.39 )], and ee for $(+)-8 c$ was determined by HPLC on a Chiral Pak IA $5 \mu$ column $(0.4 \mathrm{~cm} \times 1 \mathrm{~cm})$ [mobile phase: $n$-heaxane/2-PrOH (90:10); flow rate $5 \mathrm{~mL} \mathrm{~min}^{-1}$; detection at $205 \mathrm{~nm}$; retention time (min): 21.86 (antipode: 18.46)].

\subsection{Computational methods}

All computations were carried out with the Gaussian03 program package (G03), ${ }^{10,11}$ using standard convergence criteria, at B3LYP/6$31 \mathrm{G}(\mathrm{d}, \mathrm{p}), \quad \mathrm{B} 3 \mathrm{LYP} / 6-311++\mathrm{G}(\mathrm{d}, \mathrm{p})$ and $\mathrm{B} 3 \mathrm{LYP} / 6-311++\mathrm{G}(2 \mathrm{~d}, 2 \mathrm{p})$ levels of theory. The vibrational frequencies were computed at the same levels of theory as used for geometry optimization in order to confirm all structures as residing at minima on their potential energy hypersurfaces. Thermodynamic functions $\mathrm{U}, \mathrm{H}, \mathrm{G}$ and $\mathrm{S}$ were computed at $298.15 \mathrm{~K}$, using the quantum chemical, rather than the conventional, thermodynamic reference state.

\subsection{General procedure for the synthesis of isoxazoline-fused- $\beta$-aminocyclopentanecarboxylates}

Method A: To a solution of amino ester $\mathbf{1 a}$ or $\mathbf{1 b}(3.92 \mathrm{mmol})$ in THF ( $15 \mathrm{ml}), \mathrm{RNO}_{2}$ (2 equiv), PhNCO (2 equiv) and $\mathrm{Et}_{3} \mathrm{~N}$ ( 2 equiv) were added and the mixture was stirred under reflux for $15 \mathrm{~h}$. The reaction mixture was then diluted with EtOAc $(50 \mathrm{ml})$, washed with $\mathrm{H}_{2} \mathrm{O}(3 \times 15 \mathrm{ml})$, dried $\left(\mathrm{Na}_{2} \mathrm{SO}_{4}\right)$, and concentrated under reduced pressure. The crude residue was purified by column chromatography on silica gel ( $n$-hexane/EtOAc), giving $\mathbf{2 a - d}{ }^{9}$

Method B: To a solution of amino ester $\mathbf{6 a}$ or $\mathbf{6 b}(3 \mathrm{mmol})$ in THF $(20 \mathrm{~mL}), \mathrm{RNO}_{2}$ (3.2 mmol), DMAP $\left(0.6 \mathrm{mmol}, 20 \mathrm{~mol} \%\right.$ ) and $\mathrm{Boc}_{2} \mathrm{O}$ ( $9 \mathrm{mmol}, 3$ equiv) were added and the mixture was stirred at $20^{\circ} \mathrm{C}$ for $15 \mathrm{~h}$. The reaction mixture was then diluted with $\mathrm{H}_{2} \mathrm{O}(50 \mathrm{~mL})$ and extracted with EtOAc $(3 \times 15 \mathrm{~mL})$. The combined organic layer was washed with $5 \% \mathrm{HCl}(15 \mathrm{~mL})$ and brine $(2 \times 20 \mathrm{~mL})$, dried $\left(\mathrm{Na}_{2} \mathrm{SO}_{4}\right)$ and concentrated under reduced pressure. The crude residue was purified by column chromatography on silica gel ( $n$ hexane/EtOAc), giving $\mathbf{7 a - d .}$

3.3.1. Ethyl ( $\left.3 a R^{*}, 5 S^{*}, 6 R^{*}, 6 a S^{*}\right)-6$-(tert-butoxycarbonylamino)-3-methyl-4,5,6,6a-tetrahydro-3aH-cyclopenta[d]isoxazole-5-carboxylate (7a). A white solid; yield: $431 \mathrm{mg}, 46 \%$; mp 63-65 ${ }^{\circ} \mathrm{C} ; R_{f}=0.25$ ( $n$ hexane/EtOAc 2:1); ${ }^{1} \mathrm{H}$ NMR $\left(400 \mathrm{MHz}, \mathrm{CDCl}_{3}\right)$ : $\delta=1.28\left(\mathrm{t}, 3 \mathrm{H}, \mathrm{CH}_{3}\right.$, $J=7.1 \mathrm{~Hz}), 1.46\left(\mathrm{~s}, 9 \mathrm{H}, \mathrm{CH}_{3}\right), 1.97-1.99\left(\mathrm{~s}, 3 \mathrm{H}, \mathrm{CH}_{3}\right), 2.00-2.05(\mathrm{~m}, 1 \mathrm{H}$, $\left.\mathrm{CH}_{2}\right), 2.13-2.26\left(\mathrm{~m}, 1 \mathrm{H}, \mathrm{CH}_{2}\right), 2.38-2.48(\mathrm{~m}, 1 \mathrm{H}, \mathrm{H}-5), 3.63(\mathrm{~m}, 1 \mathrm{H}, \mathrm{H}-$ 3a), 4.11-4.34 (m, 3H, H-6 and $\mathrm{OCH}_{2}$ ), 4.89-4.94 (m, 1H, H-6a), 5.21 (br s, $1 \mathrm{H}, \mathrm{N}-\mathrm{H}$ ); ${ }^{13} \mathrm{C}$ NMR (100 MHz, DMSO): $\delta=11.5,14.8,29.0,30.7$, 36.8, 45.7, 53.6, 60.4, 61.2, 83.9, 157.6, 172.7, 173.4; MS: (ESI) $m / z=335$ $(\mathrm{M}+\mathrm{Na})$. Anal. Calcd for $\mathrm{C}_{15} \mathrm{H}_{24} \mathrm{~N}_{2} \mathrm{O}_{5}: \mathrm{C}, 57.68 ; \mathrm{H}, 7.74 ; \mathrm{N}, 8.97$. Found: C, 57.41; H, 7.58; N, 8.82.

3.3.2. Ethyl ( $\left.3 a R^{*}, 5 S^{*}, 6 R^{*}, 6 a S^{*}\right)-6$-benzamido-3-methyl-4,5,6,6a-tetrahydro-3aH-cyclopenta[d]isoxazole-5-carboxylate (7b). A white solid; yield: $398 \mathrm{mg}, 42 \%$; $\mathrm{mp} 172-174{ }^{\circ} \mathrm{C} ; R_{f}=0.15$ ( $n$-hexane/EtOAC 2:1); ${ }^{1} \mathrm{H}$ NMR $\left(400 \mathrm{MHz}, \mathrm{CDCl}_{3}\right): \delta=1.16\left(\mathrm{t}, 3 \mathrm{H}, \mathrm{CH}_{3}, J=7.1 \mathrm{~Hz}\right)$, $1.98-2.00\left(\mathrm{~s}, 3 \mathrm{H}, \mathrm{CH}_{3}\right), 2.03-2.10\left(\mathrm{~m}, 1 \mathrm{H}, \mathrm{CH}_{2}\right), 2.24-2.34(\mathrm{~m}, 1 \mathrm{H}$, $\left.\mathrm{CH}_{2}\right), 2.51-2.59(\mathrm{~m}, 1 \mathrm{H}, \mathrm{H}-5), 3.69(\mathrm{~m}, 1 \mathrm{H}, \mathrm{H}-3 \mathrm{a}), 4.10-4.17(\mathrm{~m}, 2 \mathrm{H}$, $\left.\mathrm{OCH}_{2}\right), 4.77-4.84(\mathrm{~m}, 1 \mathrm{H}, \mathrm{H}-6), 4.97-5.01$ (m, 1H, H-6a), 6.70 (br s, $1 \mathrm{H}, \mathrm{N}-\mathrm{H}), 7.41-7.53(\mathrm{~m}, 3 \mathrm{H}, \mathrm{Ar}-\mathrm{H}), 7.77-7.81(\mathrm{~m}, 2 \mathrm{H}, \mathrm{Ar}-\mathrm{H}) ;{ }^{13} \mathrm{C}$ NMR (100 MHz, DMSO): $\delta=11.6,14.9,30.8,45.1,53.9,59.3,61.0$,
83.0, 128.4, 129.0, 132.1, 135.0, 157.7, 167.1, 173.3; MS: (ESI) $m / z=317$ $(\mathrm{M}+1)$. Anal. Calcd for $\mathrm{C}_{17} \mathrm{H}_{20} \mathrm{~N}_{2} \mathrm{O}_{4}$ : C, 64.54; $\mathrm{H}, 6.37 ; \mathrm{N}, 8.86$. Found: C, 64.38; H, 6.27; N, 8.75.

3.3.3. Ethyl ( $\left.3 a R^{*}, 5 S^{*}, 6 R^{*}, 6 a S^{*}\right)-6$-(tert-butoxycarbonylamino)-3-ethyl4,5,6,6a-tetrahydro-3aH-cyclopenta[d]isoxazole-5-carboxylate (7c). A white solid; yield: $215 \mathrm{mg}, 22 \%$; mp $105-106^{\circ} \mathrm{C} ; R_{f}=0.36$ ( $n$-hexane/ EtOAc 2:1); ${ }^{1} \mathrm{H}$ NMR (400 MHz, DMSO): $\delta=1.07$ (t, 3H, $\mathrm{CH}_{3}, J=7.4 \mathrm{~Hz}$ ), $1.17\left(\mathrm{t}, 3 \mathrm{H}, \mathrm{CH}_{3}, J=7.2 \mathrm{~Hz}\right), 1.39\left(\mathrm{~s}, 9 \mathrm{H}, \mathrm{CH}_{3}\right), 1.85-2.03\left(\mathrm{~m}, 2 \mathrm{H}, \mathrm{CH}_{2}\right)$, 2.15-2.27 (m, 1H, CH $), 2.29-2.37\left(\mathrm{~m}, 1 \mathrm{H}, \mathrm{CH}_{2}\right), 2.38-2.47(\mathrm{~m}, 1 \mathrm{H}, \mathrm{H}-$ 5), $3.71(\mathrm{~m}, 1 \mathrm{H}, \mathrm{H}-3 \mathrm{a}), 3.97-4.13\left(\mathrm{~m}, 3 \mathrm{H}, \mathrm{OCH}_{2}\right.$ and $\left.\mathrm{H}-6\right), 4.71-4.76$ (m, 1H, H-6a), 6.74 (br s, $1 \mathrm{H}, \mathrm{N}-\mathrm{H}) ;{ }^{13} \mathrm{C}$ NMR (100 MHz, $\mathrm{CDCl}_{3}$ ): $\delta=11.4,14.9,19.5,29.0,30.9,45.8,52.3,60.3,61.0,78.8,83.1,155.8$, 161.9, 173.4; MS: (ESI) $m / z=227(\mathrm{M}+1)$. Anal. Calcd for $\mathrm{C}_{16} \mathrm{H}_{26} \mathrm{~N}_{2} \mathrm{O}_{5}$ : C, 58.88; H, 8.03; N, 8.58. Found: C, 58.62; H, 7.92; N, 8.44.

3.3.4. Ethyl (3aR*,5S*,6R*,6aS*)-6-benzamido-3-ethyl-4,5,6,6a-tetrahydro-3aH-cyclopenta[d]isoxazole-5-carboxylate (7d). A white solid; yield: $436 \mathrm{mg}, 44 \%$; $\mathrm{mp} 127-129^{\circ} \mathrm{C}$; $R_{f}=0.15$ ( $n$-hexane/ EtOAC 2:1); ${ }^{1} \mathrm{H}$ NMR $\left(400 \mathrm{MHz}, \mathrm{CDCl}_{3}\right): \delta=1.19$, (t, $3 \mathrm{H}, \mathrm{CH}_{3}$, $J=7.1 \mathrm{~Hz}), 1.26\left(\mathrm{t}, 3 \mathrm{H}, \mathrm{CH}_{3}, J=7.1 \mathrm{~Hz}\right), 2.06-2.12\left(\mathrm{~m}, 1 \mathrm{H}, \mathrm{CH}_{2}\right)$, 2.23-2.37 ( $\left.\mathrm{m}, 2 \mathrm{H}, \mathrm{CH}_{2}\right), 2.44-2.63\left(\mathrm{~m}, 2 \mathrm{H}, \mathrm{CH}_{2}\right.$ and $\left.\mathrm{H}-5\right), 3.77(\mathrm{~m}$, $1 \mathrm{H}, \mathrm{H}-3 \mathrm{a}), 4.12-4.21\left(\mathrm{~m}, 2 \mathrm{H}, \mathrm{OCH}_{2}\right), 4.80-4.87(\mathrm{~m}, 1 \mathrm{H}, \mathrm{H}-6)$, 4.98-5.03 (m, 1H, H-6a), 6.75 (b rs, $1 \mathrm{H}, \mathrm{N}-\mathrm{H}), 7.44-7.49(\mathrm{~m}, 2 \mathrm{H}$, $\mathrm{Ar}-\mathrm{H}), 7.51-7.56(\mathrm{~m}, 1 \mathrm{H}, \mathrm{Ar}-\mathrm{H}), 7.77-7.85(\mathrm{~m}, 2 \mathrm{H}, \mathrm{Ar}-\mathrm{H}) ;{ }^{13} \mathrm{C}$ NMR $\left(100 \mathrm{MHz}, \mathrm{CDCl}_{3}\right): \delta=11.1,14.4,19.9,30.7,47.1,52.4,59.0,61.6,83.5$, 127.5, 129.0, 132.1, 134.5, 162.3, 167.5, 172.6; MS: (ESI) $m / z=331$ $(\mathrm{M}+1)$. Anal. Calcd for $\mathrm{C}_{18} \mathrm{H}_{22} \mathrm{~N}_{2} \mathrm{O}_{4}$ : C, 65.44; $\mathrm{H}, 6.71 ; \mathrm{N}, 8.48$. Found: C, 65.23; H, 6.63; N, 8.29.

\subsection{General procedure for the synthesis of isoxazoline-fused- $\beta$-amino esters $8 a-d$ and $9 a-d$ by epimerization of $2 a-d$ and 3a-d}

To a solution of isoxazoline-fused $\beta$-aminocyclopentanecarboxylate $\mathbf{2 a}-\mathbf{d}$ and $\mathbf{3 a}-\mathbf{d}(1 \mathrm{mmol})$ in $\mathrm{EtOH}(10 \mathrm{ml})$, NaOEt ( $1.2 \mathrm{mmol})$ was added and the mixture was stirred at room temperature for $12 \mathrm{~h}$. The mixture was then concentrated under reduced pressure, and the residue was then diluted with $\mathrm{CHCl}_{3}(30 \mathrm{ml})$, washed with $\mathrm{H}_{2} \mathrm{O}(3 \times 10 \mathrm{ml})$, dried $\left(\mathrm{Na}_{2} \mathrm{SO}_{4}\right)$ and concentrated under reduced pressure. The crude residue was purified by crystallization ( $n$-hexane/EtOAc) or column chromatography on silica gel ( $n$-hexane/ EtOAc 5:1).

3.4.1. Ethyl $\left(3 a R^{*}, 4 S^{*}, 5 S^{*}, 6 a R^{*}\right)-4$-(tert-butoxycarbonylamino)-3methyl-4,5,6,6a-tetrahydro-3aH-cyclopenta[d]isoxazole-5-carboxylate $(\boldsymbol{8 a})$. A white solid; yield: $234 \mathrm{mg}, 75 \%$; $\mathrm{mp} \mathrm{92-94}{ }^{\circ} \mathrm{C} ; R_{f}=0.63$ ( $n$-hexane/EtOAc 1:2); ${ }^{1} \mathrm{H}$ NMR (400 MHz, $\left.\mathrm{CDCl}_{3}\right): \delta=1.28(\mathrm{t}, 3 \mathrm{H}$, $\left.\mathrm{CH}_{3}, J=7.1 \mathrm{~Hz}\right), 1.48\left(\mathrm{~s}, 9 \mathrm{H}, \mathrm{CH}_{3}\right), 2.11\left(\mathrm{~s}, 3 \mathrm{H}, \mathrm{CH}_{3}\right), 2.25-2.34(\mathrm{~m}, 1 \mathrm{H}$ $\left.\mathrm{CH}_{2}\right), 2.42-2.50\left(\mathrm{~m}, 1 \mathrm{H}, \mathrm{CH}_{2}\right), 2.82-2.91(\mathrm{~m}, 1 \mathrm{H}, \mathrm{H}-5), 3.49-3.57$ (m, 1H, H-3a), 4.10-4.22 (m, OCH $), 4.34-4.40$ (m, 1H, H-4), 4.82 (br s, $1 \mathrm{H}, \mathrm{N}-\mathrm{H}), 5.06-5.13(\mathrm{~m}, 1 \mathrm{H}, \mathrm{H}-6 \mathrm{a}) ;{ }^{13} \mathrm{C}$ NMR $(100 \mathrm{MHz}$, $\left.\mathrm{CDCl}_{3}\right): \delta=12.2,14.5,28.7,36.8,49.7,58.1,61.6,63.3,83.9,98.0$, 106.9, 155.2, 172.1; MS: (ESI) $m / z=313(\mathrm{M}+1)$. Anal. Calcd for $\mathrm{C}_{15} \mathrm{H}_{24} \mathrm{~N}_{2} \mathrm{O}_{5}$ : C, 57.68; H, 7.74; N, 8.97. Found: C, 57.43; H, 7.61; $\mathrm{N}, 8.90$.

3.4.2. Ethyl ( $\left.3 a R^{*}, 4 S^{*}, 5 S^{*}, 6 a R^{*}\right)-4$-benzamido-3-methyl-4,5,6,6a-tetrahydro-3aH-cyclopenta[d]isoxazole-5-carboxylate $(\boldsymbol{8 b})$. A white solid; yield: $117 \mathrm{mg}, 37 \%$; mp $142-144{ }^{\circ} \mathrm{C} ; R_{f}=0.3$ (n-hexane/EtOAC 1:1); $\left.{ }^{1} \mathrm{H} \mathrm{NMR} \mathrm{(400} \mathrm{MHz,} \mathrm{CDCl}_{3}\right): \delta=1.22-1.3\left(\mathrm{t}, 3 \mathrm{H}, \mathrm{CH}_{3}, J=7.1 \mathrm{~Hz}\right)$, $2.16\left(\mathrm{~s}, 3 \mathrm{H}, \mathrm{CH}_{3}\right), 2.26-2.36\left(\mathrm{~m}, 1 \mathrm{H}, \mathrm{CH}_{2}\right), 2.50-2.61\left(\mathrm{~m}, 1 \mathrm{H}, \mathrm{CH}_{2}\right)$, 3.05-3.13 (m, 1H, H-5), 3.69-3.76 (m, 1H, H-3a), 4.12-4.20 (m, 2H, $\left.\mathrm{OCH}_{2}\right), 4.72-4.79(\mathrm{~m}, 1 \mathrm{H}, \mathrm{H}-4), 5.12-5.21(\mathrm{~m}, 1 \mathrm{H}, \mathrm{H}-6 \mathrm{a}), 6.47-6.69$ (br s, $1 \mathrm{H}, \mathrm{N}-\mathrm{H}), 7.43-7.50(\mathrm{~m}, 2 \mathrm{H}, \mathrm{Ar}-\mathrm{H}), 7.52-7.58(\mathrm{~m}, 1 \mathrm{H}, \mathrm{Ar}-\mathrm{H})$, 7.76-7.80 (m, $2 \mathrm{H}, \mathrm{Ar}-\mathrm{H}) ;{ }^{13} \mathrm{C}$ NMR $\left(100 \mathrm{MHz} \mathrm{CDCl}_{3}\right): \delta=12.3,14.5$, 
30.1, 36.9, 49.4, 57.5, 61.7, 63.0, 126.3, 127.3, 129.1, 132.4, 134.3, 156.3, 172.1; MS: (ESI) $m / z=317(\mathrm{M}+1)$. Anal. Calcd for $\mathrm{C}_{17} \mathrm{H}_{20} \mathrm{~N}_{2} \mathrm{O}_{4}$ : $\mathrm{C}$, 64.54; H, 6.37; N, 8.86. Found: C, 64.41; H, 6.21; N, 8.70.

3.4.3. Ethyl (3aR*,4S*,5S*,6aR*)-4-(tert-butoxycarbonylamino)-3ethyl-4,5,6,6a-tetrahydro-3aH-cyclopenta[d]isoxazole-5-carboxylate (8c). A white solid; yield: $98 \mathrm{mg}, 30 \%$; mp $119-121^{\circ} \mathrm{C} ; R_{f}=0.42(n-$ hexane/EtOAc 2:1); ${ }^{1} \mathrm{H}$ NMR (400 MHz, DMSO): $\delta=1.07$ (t, 3H, $\mathrm{CH}_{3}$, $J=7.47 \mathrm{~Hz}), 1.14\left(\mathrm{t}, 3 \mathrm{H}, \mathrm{CH}_{3}, J=7.1 \mathrm{~Hz}\right), 1.38\left(\mathrm{~s}, 9 \mathrm{H}, \mathrm{CH}_{3}\right), 1.87-1.96(\mathrm{~m}$ $\left.1 \mathrm{H}, \mathrm{CH}_{2}\right), 2.23-2.46\left(\mathrm{~m}, 3 \mathrm{H}, \mathrm{CH}_{2}\right), 2.48-2.51(\mathrm{~m}, 1 \mathrm{H}, \mathrm{H}-5)$, 2.72-2.79 (m, 1H, H-3a), $3.45(\mathrm{dd}, 1 \mathrm{H}, \mathrm{H}-4, J=5.0$ and $5.1 \mathrm{~Hz}$ ), 3.96-4.06 ( $\left.\mathrm{m}, 2 \mathrm{H}, \mathrm{OCH}_{2}\right), 4.10-4.17(\mathrm{~m}, 1 \mathrm{H}, \mathrm{H}-6 \mathrm{a}), 4.89-4.96$ (br s, $1 \mathrm{H}, \mathrm{N}-\mathrm{H}) ;{ }^{13} \mathrm{C}$ NMR $\left(100 \mathrm{MHz}, \mathrm{CDCl}_{3}\right): \delta=11.3,14.8,20.2,29.0,36.7$, 49.7, 58.5, 61.2, 61.7, 79.1, 83.9, 155.7, 160.7, 172.7; MS: (ESI) $m / z=327(\mathrm{M}+1)$. Anal. Calcd for $\mathrm{C}_{16} \mathrm{H}_{26} \mathrm{~N}_{2} \mathrm{O}_{5}: \mathrm{C}, 58.88 ; \mathrm{H}, 8.03 ; \mathrm{N}$, 8.58. Found: C, $58.71 ; \mathrm{H}, 7.85 ; \mathrm{N}, 8.30$.

3.4.4. Ethyl $\left(3 a R^{*}, 4 S^{*}, 5 S^{*}, 6 a R^{*}\right)$-4-benzamido-3-ethyl-4,5,6,6a-tetrahydro-3aH-cyclopenta[d]isoxazole-5-carboxylate $(\mathbf{8 d})$. A white solid; yield: $149 \mathrm{mg}, 45 \%$; mp $136-137{ }^{\circ} \mathrm{C} ; R_{f}=0.46$ (n-hexane/ EtOAc 1:1); ${ }^{1} \mathrm{H}$ NMR (400 MHz, DMSO): $\delta=1.05\left(\mathrm{t}, 3 \mathrm{H}, \mathrm{CH}_{3}\right.$, $J=7.15 \mathrm{~Hz}), 1.07\left(\mathrm{t}, 3 \mathrm{H}, \mathrm{CH}_{3}, J=7.2 \mathrm{~Hz}\right), 1.93-2.01\left(\mathrm{~m}, 1 \mathrm{H}, \mathrm{CH}_{2}\right)$, $2.23-2.34\left(\mathrm{~m}, 1 \mathrm{H}, \mathrm{CH}_{2}\right), 2.36-2.53\left(\mathrm{~m}, 2 \mathrm{H}, \mathrm{CH}_{2}\right), 2.91-2.99(\mathrm{~m}, 1 \mathrm{H}$, $\mathrm{H}-5), 3.63(\mathrm{dd}, 1 \mathrm{H}, \mathrm{H}-3 \mathrm{a}, J=5.0$ and $5.1 \mathrm{~Hz}), 3.93-4.01(\mathrm{~m}, 2 \mathrm{H}$, $\left.\mathrm{OCH}_{2}\right), 4.57-4.64(\mathrm{~m}, 1 \mathrm{H}, \mathrm{H}-4), 4.95-5.02(\mathrm{~m}, 1 \mathrm{H}, \mathrm{H}-6 \mathrm{a}), 7.42-7.54$ (m, 3H, Ar-H), 7.77-7.81 (m, 2H, Ar-H), 8.66 (br s, $1 \mathrm{H}, \mathrm{N}-\mathrm{H}) ;{ }^{13} \mathrm{C}$ NMR (100 MHz, DMSO): $\delta=11.4,14.7,20.3,36.9,49.6,57.4,61.2$, $61.5,84.1,128.1,129.2,132.3,134.0,136.5,158.0,171.8$; MS: (ESI) $m /$ $z=331(\mathrm{M}+1)$. Anal. Calcd for $\mathrm{C}_{18} \mathrm{H}_{22} \mathrm{~N}_{2} \mathrm{O}_{4}: \mathrm{C}, 65.44 ; \mathrm{H}, 6.71 ; \mathrm{N}, 8.48$. Found: $\mathrm{C}, 65.21 ; \mathrm{H}, 6.80 ; \mathrm{N}, 8.30$.

3.4.5. Ethyl (3aS*,5S*,6R*,6aR*)-6-(tert-butoxycarbonylamino)-3methyl-4,5,6,6a-tetrahydro-3aH-cyclopenta[d]isoxazole-5-carboxylate (9a). A white solid; yield: $62 \mathrm{mg}, 20 \%$; $\mathrm{mp} 113-115^{\circ} \mathrm{C} ; R_{f}=0.47$ ( $n$-hexane/EtOAc 1:2); ${ }^{1} \mathrm{H}$ NMR $\left(400 \mathrm{MHz}, \mathrm{CDCl}_{3}\right): \delta=1.26(\mathrm{t}, 3 \mathrm{H}$, $\left.\mathrm{CH}_{3}, J=7.2 \mathrm{~Hz}\right), 1.44\left(\mathrm{~s}, 9 \mathrm{H}, \mathrm{CH}_{3}\right), 1.97-1.98\left(\mathrm{~s}, 3 \mathrm{H}, \mathrm{CH}_{3}\right), 2.03-2.12$ $\left(\mathrm{m}, 1 \mathrm{H}, \mathrm{CH}_{2}\right), 2.24-2.34\left(\mathrm{~m}, 1 \mathrm{H}, \mathrm{CH}_{2}\right), 3.08-3.20(\mathrm{~m}, 1 \mathrm{H}, \mathrm{H}-5)$, 3.54-3.62 (m, 1H, H-3a), 3.93-4.04 (m, 1H, H-6), 4.11-4.18 (m, $2 \mathrm{H}$, $\mathrm{OCH}_{2}$ ), 4.83 (br s, $\left.1 \mathrm{H}, \mathrm{N}-\mathrm{H}\right), 5.00-5.10(\mathrm{~m}, 1 \mathrm{H}, \mathrm{H}-6 \mathrm{a}) ;{ }^{13} \mathrm{C}$ NMR $\left(100 \mathrm{MHz}, \mathrm{CDCl}_{3}\right): \delta=11.8,14.5,28.7,28.8,30.8,53.7,59.9,61.5,63.6$, 101.3, 139.9, 155.4, 157.8; MS: (ESI) $m / z=335(\mathrm{M}+\mathrm{Na})$. Anal. Calcd for $\mathrm{C}_{15} \mathrm{H}_{24} \mathrm{~N}_{2} \mathrm{O}_{5}$ : C, 57.68; $\mathrm{H}, 7.74 ; \mathrm{N}$, 8.97. Found: C, $57.41 ; \mathrm{H}, 7.63 ; \mathrm{N}$, 8.92 .

3.4.6. Ethyl (3aS*,5S*,6R*,6aR*)-6-benzamido-3-methyl-4,5,6,6a-tetrahydro-3aH-cyclopenta[d]isoxazole-5-carboxylate (9b). A white solid; yield: $95 \mathrm{mg}, 30 \%$; mp $181-183{ }^{\circ} \mathrm{C} ; R_{f}=0.23$ ( $n$-hexane/EtOAc $1: 1) ;{ }^{1} \mathrm{H}$ NMR $\left(400 \mathrm{MHz}, \mathrm{CDCl}_{3}\right): \delta=1.23\left(\mathrm{t}, 3 \mathrm{H}, \mathrm{CH}_{3}, J=7.2 \mathrm{~Hz}\right), 1.42$ (s, 3H, $\left.\mathrm{CH}_{3}\right), 2.05-2.12\left(\mathrm{~m}, 1 \mathrm{H}, \mathrm{CH}_{2}\right), 2.44-2.55\left(\mathrm{~m}, 1 \mathrm{H}, \mathrm{CH}_{2}\right)$, $3.49-3.58(\mathrm{~m}, 1 \mathrm{H}, \mathrm{H}-5), 3.71-3.79(\mathrm{~m}, 1 \mathrm{H}, \mathrm{H}-3 \mathrm{a}), 4.13-4.20(\mathrm{~m}, 2 \mathrm{H}$, $\left.\mathrm{OCH}_{2}\right), 4.21-4.29(\mathrm{~m}, 1 \mathrm{H}, \mathrm{H}-6), 5.40(\mathrm{dd}, 1 \mathrm{H}, \mathrm{H}-6 \mathrm{a}, J=5.0$ and $5.2 \mathrm{~Hz}$ ), 6.65 (br s, $1 \mathrm{H}, \mathrm{N}-\mathrm{H}), 7.44-7.49(\mathrm{~m}, 2 \mathrm{H}, \mathrm{Ar}-\mathrm{H}), 7.52-7.57$ $(\mathrm{m}, 1 \mathrm{H}, \mathrm{Ar}-\mathrm{H}), 7.76-7.80(\mathrm{~m}, 2 \mathrm{H}, \mathrm{Ar}-\mathrm{H}) ;{ }^{13} \mathrm{C}$ NMR $(100 \mathrm{MHz}$, $\left.\mathrm{CDCl}_{3}\right): \delta=11.86,14.52,27.56,31.29,47.26,53.91,61.59,63.88,88.26$, 122.64, 126.92, 127.33, 129.05, 132.20, 148.00, 182.23; MS: (ESI) $m / z=317(\mathrm{M}+1)$. Anal. Calcd for $\mathrm{C}_{17} \mathrm{H}_{20} \mathrm{~N}_{2} \mathrm{O}_{4}: \mathrm{C}, 64.54 ; \mathrm{H}, 6.37 ; \mathrm{N}$, 8.86. Found: C, 64.39; H, 6.25; N, 8.69.

3.4.7. Ethyl (3aS*,5S*,6R*,6aR*)-6-(tert-butoxycarbonylamino)-3ethyl-4,5,6,6a-tetrahydro-3aH-cyclopenta[d]isoxazole-5-carboxylate (9c). A white solid; yield: $75 \mathrm{mg}, 23 \%$; mp $113-115{ }^{\circ} \mathrm{C}$; $R_{f}=0.61$ ( $n$-hexane/EtOAc 1:1); ${ }^{1} \mathrm{H}$ NMR $\left(400 \mathrm{MHz}, \mathrm{CDCl}_{3}\right): \delta=1.21(\mathrm{t}, 3 \mathrm{H}$, $\mathrm{CH}_{3}, J=7.5 \mathrm{~Hz}$ ), $1.26-1.32\left(\mathrm{t}, 3 \mathrm{H}, \mathrm{CH}_{3}, J=7.4 \mathrm{~Hz}\right), 1.47\left(\mathrm{~s}, 9 \mathrm{H}, \mathrm{CH}_{3}\right)$, $2.03-2.14\left(\mathrm{~m}, 1 \mathrm{H}, \mathrm{CH}_{2}\right), 2.24-2.38\left(\mathrm{~m}, 2 \mathrm{H}, \mathrm{CH}_{2}\right), 2.44-2.55(\mathrm{~m}, 1 \mathrm{H}$, $\left.\mathrm{CH}_{2}\right), 3.11-3.25(\mathrm{~m}, 1 \mathrm{H}, \mathrm{H}-5), 3.62-3.70(\mathrm{~m}, 1 \mathrm{H}, \mathrm{H}-3 \mathrm{a}), 4.95-4.07$ (m, 1H, H-6), 4.14-4.20 (m, 2H, OCH $)_{2}, 4.82-4.93(\mathrm{~m}, 1 \mathrm{H}, \mathrm{H}-6 \mathrm{a})$,
5.08 (br s, $1 \mathrm{H}, \mathrm{N}-\mathrm{H}) ;{ }^{13} \mathrm{C}$ NMR (100 MHz, $\left.\mathrm{CDCl}_{3}\right): \delta=11.0,14.5,20.2$, 28.7, 30.1, 31.1, 52.4, 61.5, 63.4, 117.5, 119.5, 124.4, 155.4, 162.3; MS: (ESI) $m / z=349(\mathrm{M}+\mathrm{Na})$. Anal. Calcd for $\mathrm{C}_{16} \mathrm{H}_{26} \mathrm{~N}_{2} \mathrm{O}_{5}$ : C, 58.88; $\mathrm{H}$, 8.03; N, 8.58. Found: C, 58.73; H, 7.85; N, 8.31.

3.4.8. Ethyl $\left(3 a S^{*}, 5 S^{*}, 6 R^{*}, 6 a R^{*}\right)-6$-benzamido-3-ethyl-4,5,6,6a-tetrahydro-3aH-cyclopenta[d]isoxazole-5-carboxylate (9d). A white solid; yield: $33 \mathrm{mg}, 10 \%$; mp $192-194{ }^{\circ} \mathrm{C} ; R_{f}=0.39$ ( $n$-hexane/EtOAc 1:1) and ${ }^{1} \mathrm{H}$ NMR (400 MHz, DMSO): $\delta=1.05\left(\mathrm{t}, 3 \mathrm{H}, \mathrm{CH}_{3}, J=7.2 \mathrm{~Hz}\right)$, $1.10\left(\mathrm{t}, 3 \mathrm{H}, \mathrm{CH}_{3}, J=7.2 \mathrm{~Hz}\right), 1.94-2.05\left(\mathrm{~m}, 1 \mathrm{H}, \mathrm{CH}_{2}\right), 2.21-2.43(\mathrm{~m}, 3 \mathrm{H}$ $\left.\mathrm{CH}_{2}\right), 2.90-2.98(\mathrm{~m}, 1 \mathrm{H}, \mathrm{H}-5), 3.72-3.80(\mathrm{~m}, 1 \mathrm{H}, \mathrm{H}-3 \mathrm{a}), 3.92-4.05$ $\left(\mathrm{m}, 2 \mathrm{H}, \mathrm{OCH}_{2}\right), 4.40-4.47(\mathrm{~m}, 1 \mathrm{H}, \mathrm{H}-6), 4.92(\mathrm{dd}, 1 \mathrm{H}, \mathrm{H}-6 \mathrm{a}, J=4.8$ and $7.7 \mathrm{~Hz}$ ), 7.44-7.57 (m, 3H, Ar-H), $7.83(\mathrm{~d}, 2 \mathrm{H}, \mathrm{Ar}-\mathrm{H}, J=7.5 \mathrm{~Hz}), 8.65$ (br s, $1 \mathrm{H}, \mathrm{N}-\mathrm{H}) ;{ }^{13} \mathrm{C}$ NMR (100 MHz, DMSO): $\delta=11.3,14.7,19.9,30.9$, 48.7, 52.4, 61.2, 61.9, 89.1, 128.1, 129.2, 132.2, 135.1, 162.7, 167.1, 172.7; MS: (ESI) $m / z=331(\mathrm{M}+1)$. Anal. Calcd for $\mathrm{C}_{18} \mathrm{H}_{22} \mathrm{~N}_{2} \mathrm{O}_{4}$ : $\mathrm{C}$, 65.44; H, 6.71; N, 8.48. Found: C, 65.20; H, 6.56; N, 8.28.

\subsection{Characterization of the enantiomers}

The ${ }^{1} \mathrm{H}$ NMR spectra of the enantiomeric substances were the same as those of the corresponding racemic compounds.

3.5.1. Ethyl (1S,2S)-2-(tert-butoxycarbonylamino)cyclopent-3-enecarboxylate $[(+)-6 a]$. A white solid; yield: $58 \% ; \mathrm{mp}=58-60{ }^{\circ} \mathrm{C}$; $[\alpha]_{\mathrm{D}}^{25}+121.7$ ( c 0.38, EtOH).

3.5.2. Ethyl (3aR,4S,5R,6aR)-4-(tert-butoxycarbonylamino)-3-methyl4,5,6,6a-tetrahydro-3aH-cyclopenta[d]isoxazole-5-carboxylate $[(-)-2 a]$. A white solid; yield: $53 \%$; mp $80-82^{\circ} \mathrm{C} ;[\alpha]_{\mathrm{D}}^{25}-8.3($ c 0.4 , EtOH).

3.5.3. Ethyl (3aR,4S,5R,6aR)-4-(tert-butoxycarbonylamino)-3-ethyl4,5,6,6a-tetrahydro-3aH-cyclopenta[d]isoxazole-5-carboxylate $[(-)-2 c]$. A white solid; yield: $40 \%$; mp $105-107^{\circ} \mathrm{C} ;[\alpha]_{\mathrm{D}}^{25}-2(c 0.1$, EtOH).

3.5.4. Ethyl (3aR,4S,5S,6aR)-4-(tert-butoxycarbonylamino)-3-methyl4,5,6,6a-tetrahydro-3aH-cyclopenta[d]isoxazole-5-carboxylate $[(+)-8 a]$. A white solid; yield: $22 \%$; mp 90-93 ${ }^{\circ} \mathrm{C} ;[\alpha]_{\mathrm{D}}^{25}+20(c 0.28$, EtOH).

3.5.5. Ethyl (3aR,4S,5S,6aR)-4-(tert-butoxycarbonylamino)-3-ethyl4,5,6,6a-tetrahydro-3aH-cyclopenta[d]isoxazole-5-carboxylate $[(+)-8 c]$. A white solid; yield: $25 \%$; mp $119-121^{\circ} \mathrm{C} ;[\alpha]_{\mathrm{D}}^{25}+20$ (c 0.37, EtOH)

3.5.6. Ethyl (3aR,5S,6R,6aS)-6-(tert-butoxycarbonylamino)-3-methyl4,5,6,6a-tetrahydro-3aH-cyclopenta[d]isoxazole-5-carboxylate $[(+)-7 a]$. Yellow oil; yield: 52\%; $[\alpha]_{\mathrm{D}}^{25}+105$ ( c 0.39, EtOH).

3.5.7. Ethyl (3aR,5S,6R,6aS)-6-(tert-butoxycarbonylamino)-3-ethyl4,5,6,6a-tetrahydro-3aH-cyclopenta[d]isoxazole-5-carboxylate $[(+)-7 c]$. A white solid; yield: $34 \%$; mp $105-107^{\circ} \mathrm{C} ;[\alpha]_{\mathrm{D}}^{25}+136(c$ $0.30, \mathrm{EtOH})$.

\section{Acknowledgements}

We are grateful to the Hungarian Research Foundation (OTKA No. T81371) and TÁMOP-4.2.1/B-09/1/KONV-2010-0005 for financial support and acknowledge the receipt of Bolyai János Fellowship for L.K. and E.F. 


\section{References and notes}

1. (a) Nair, V.; Suja, T. D. Tetrahedron 2007, 63, 12247; (b) Gothelf, K. V.; Jorgensen, K. A. Chem. Rev. 1998, 98, 863; (c) Gallos, J. K.; Koumbis, A. E. Curr. Org. Chem. 2003, 7, 397; (d) Pellisier, H. Tetrahedron 2007, 63, 3235; (e) Kobayashi, S.; Jorgensen, K. A. Cycloaddition Reactions in Organic Synthesis; Wiley-VCH: Weiheim, 2002; (f) Torsell, K. B. G. Nitrile Oxides, Nitrones and Nitronates in Organic Synthesis; VCH: New York, NY, 1988; (g) Namboothiri, I. N. N.; Rastogi, N.; Ganguly, B.; Mobin, S. M.; Cojocaru, M. Tetrahedron 2004, 60, 1453.

2. Christl, M.; Huisgen, R. Chem. Ber. 1973, 106, 3345.

3. Mukaiyama, T.; Hoshino, T. J. Am. Chem. Soc. 1960, 62, 5339.

4. (a) Pinto, A.; Conti, P.; De Amici, M.; Tamborini, L.; Grazioso, G.; Colleoni, S.; Mennini, T.; Gobbi, M.; De Micheli, C. Tetrahedron: Asymmetry 2008, 19, 867; (b) Conti, P.; Caligiuri, A.; Pinto, A.; Roda, G.; Tamborini, L.; Nielsen, B.; Madsen, U.; Frydenvang, K.; Colombo, A.; De Micheli, C. Eur. J. Med. Chem. 2007, 42, 1059; (c) Roda, G.; Conti, P.; De Amici, M.; He, J.; Polavaropu, P. L.; De Micheli, C. Tetrahedron: Asymmetry 2004, 15, 3079; (d) Conti, P.; De Amici, M.; Di Ventimiglia, S. J.; Stensbol, T. B.; Madsen, U.; Osborne, H. B.; Russo, E.; De Sarro, G.; Bruno, G.; De Micheli, C. J. Med. Chem. 2003, 46, 3102.

5. (a) Chand, P.; Bantia, S.; Kotian, P. L.; El-Kattan, Y.; Lin, T.-H.; Babu, Y. S. Bioorg. Med. Chem. 2005, 13, 4071; (b) Chand, P.; Kotian, P. L.; Dehghani, A.; El-Kattan, Y.; Lin, T.-H.; Hutchison, T. L.; Babu, Y. S.; Bantia, S.; Elliot, A. J.; Montgomery, J. A. J. Med. Chem. 2001, 44, 4379; (c) Mineno, T.; Miller, M. J. J. Org. Chem. 2003, 68, 6591.

6. (a) Quadrelli, P.; Piccanello, A.; Mella, M.; Corsaro, A.; Pistara, V. Tetrahedron 2008, 64, 3541; (b) Quadrelli, P.; Piccanello, A.; Martinez, N. V.; Bovio, B.; Mella, M.; Caramella, P. Tetrahedron 2006, 62, 7370 .

7. (a) Fülöp, F. Chem. Rev. 2001, 101, 2181; (b) Park, K.-H.; Kurth, M. J. Tetrahedron 2002, 58, 8629; (c) Mittendorf, J.: Kunisch, F; Matzke, M.; Militzer, H.-C. Schmidt, A.; Schönfeld, W. Bioorg. Med. Chem. Lett. 2003, 13, 433; (d) Hamersak, Z.; Roje, M.; Avdagic, A.; Sunjic, V. Tetrahedron: Asymmetry 2007, 18, 635; (e) Yang, D.; Zhang, D.-W.; Hao, Y.; Wu, Y.-D.; Luo, S.-W.; Zhu, N.-Y. Angew. Chem., Int. Ed. 2004, 43, 6719; (f) Rathore, N.; Gellman, S. H.; Pablo, J. J. Biophys. J. 2006, 91, 3425.

8. (a) Porter, E. A.; Weisblum, B.; Gellman, S. H. J. Am. Chem. Soc. 2005, 127, 11516; (b) Chandrasekhar, S.; Sudhakar, A.; Kiran, M. U.; Babu, B. N.; Jagadeesh, B.
Tetrahedron Lett. 2008, 49, 7368; (c) Rua, F.; Boussert, S.; Parella, T.; Diez-Perez, I.; Branchadell, V.; Giralt, E.; Ortuno, R. M. Org. Lett. 2007, 9, 3643; (d) D'Elia, V.; Zwicknagl, H.; Reiser, O. J. Org. Chem. 2008, 73, 3262; (e) Fülöp, F; Martinek, T. A.; Tóth, G. K. Chem. Soc. Rev. 2006, 35, 323; (f) Hetényi, A.; Mándity, I. M.; Martinek, T. A.; Tóth, G. K.; Fülöp, F. J. Am. Chem. Soc. 2005, 127, 547; (g) Torres, E.; Acosta-Silva, C.; Rua, F.; Alvarez-Larena, A.; Parella, T.; Branchadell, V.; Ortuno, R. M. Tetrahedron 2009, 65, 5669; (h) Fernandez, D.; Torres, E.; Aviles, F. X. Ortuno, R. M.: Vendrell, J. Bioorg. Med. Chem. 2009, 17, 3824; (i) Fernandes, C.; Pereira, E.; Faure, S.; Aitken, D. J. J. Org. Chem. 2009, 74, 3217; (j) Kiss, L.; Forró, E.; Fülöp, F. In Synthesis of carbocyclic $\beta$-amino acids; Hughes, A. B., Ed.; Amino Acids, Peptides and Proteins in Organic Chemistry; Wiley: Weinheim, 2009; Vol. 1, p 367.

9. Kiss, L.; Nonn, M.; Forró, E.; Sillanpää, R.; Fülöp, F. Tetrahedron Lett. 2009, 50, 2605.

10. Becke, A. D. J. Chem. Phys. 1993, 98, 5648.

11. Frisch, M. J.; Trucks, G. W.; Schlegel, H. B.; Scuseria, G. E.; Robb, M. A.; Cheeseman, J. R.; Montgomery, J. A., Jr.; Vreven, T.; Kudin, K. N.; Burant, J. C.; Millam, J. M.; Iyengar, S. S.; Tomasi, J.; Barone, V.; Mennucci, B.; Cossi, M.; Scalmani, G.; Rega, N.; Petersson, G. A.; Nakatsuji, H.; Hada, M.; Ehara, M.; Toyota, K.; Fukuda, R.; Hasegawa, J.; Ishida, M.; Nakajima, T.; Honda, Y.; Kitao, O.; Nakai, H.; Klene, M.; Li, X.; Knox, J. E.; Hratchian, H. P.; Cross, J. B.; Adamo, C.; Jaramillo, J.; Gomperts, R. Stratmann, R. E. Yazyev, O.; Austin, A. J.; Cammi, R.; Pomelli, C.; Ochterski, J. W.; Ayala, P. Y.; Morokuma, K.; Voth, G. A.; Salvador, P.; Dannenberg, J. J.; Zakrzewski, V. G.; Dapprich, S.; Daniels, A. D.; Strain, M. C.; Farkas, O.; Malick, D. K.; Rabuck, A. D.; Raghavachari, K.; Foresman, J. B.; Ortiz, J. V.; Cui, Q.; Baboul, A. G.; Clifford, S.; Cioslowski, J.; Stefanov, B. B.; Liu, G.; Liashenko, A.; Piskorz, P.; Komaromi, I.; Martin, R. L.; Fox, D. J.; Keith, T.; Al-Laham, M. A.; Peng, C. Y.; Nanayakkara, A.; Challacombe, M.; Gill, P. M. W.; Johnson, B.; Chen, W.; Wong, M. W.; Gonzalez, C.; Pople, J. A. Gaussian 03, Revision B.05; Gaussian: Pittsburgh, PA, 2003

12. Mucsi, Z.; Szabó, A.; Hermecz, I.; Kucsman, Á; Csizmadia, I. G. J. Am. Chem. Soc. 2005, 127, 7615.

13. Forró, E.; Fülöp, F. Tetrahedron: Asymmetry 2004, 15, 2875.

14. Forró, E. J. Chromatogr., A 2009, 1216, 1025.

15. Kiss, L.; Forró, E.; Sillanpää, R.; Fülöp, F. J. Org. Chem. 2007, 72, 8786. 
III. 


\title{
Synthesis of highly functionalized $\beta$-aminocyclopentanecarboxylate stereoisomers by reductive ring opening reaction of isoxazolines
}

\author{
Melinda Nonn ${ }^{1}$, Loránd Kiss ${ }^{1}$, Reijo Sillanpää ${ }^{2}$ and Ferenc Fülöp ${ }^{* 1,3}$
}

\section{Full Research Paper}

\section{Address:}

${ }^{1}$ Institute of Pharmaceutical Chemistry, University of Szeged, Eötvös u. 6, H-6720 Szeged, Hungary, ${ }^{2}$ Department of Chemistry, University of Jyväskylä, FIN-40014 Jyväskylä, Finland and ${ }^{3}$ Stereochemistry

Research Group of the Hungarian Academy of Sciences, University of Szeged, Eötvös u. 6, H-6720 Szeged, Hungary

\section{Email:}

Ferenc Fülöp* - fulop@pharm.u-szeged.hu

* Corresponding author

Keywords:

amino acids; cycloaddition; functionalization; isoxazolines; reduction

\author{
Beilstein J. Org. Chem. 2012, 8, 100-106. \\ doi:10.3762/bjoc.8.10 \\ Received: 05 October 2011 \\ Accepted: 23 December 2011 \\ Published: 17 January 2012 \\ Associate Editor: D. Dixon \\ () 2012 Nonn et al; licensee Beilstein-Institut. \\ License and terms: see end of document.
}

\begin{abstract}
A rapid and simple procedure was devised for the synthesis of multifunctionalized cyclic $\beta$-amino esters and $\gamma$-amino alcohols via the 1,3-dipolar cycloaddition of nitrile oxides to $\beta$-aminocyclopentenecarboxylates. The opening of the isoxazoline reductive ring to the corresponding highly functionalized 2-aminocyclopentanecarboxylates occurred stereoselectively with good yields.
\end{abstract}

\section{Introduction}

Isoxazoline-fused amino acids are important bioactive derivatives in organic and medicinal chemistry (e.g., conformationally restricted aspartate and glutamate analogues) [1-6]. As a consequence of their ability to undergo reductive ring opening, isoxazolines are of interest as precursors for the synthesis of highly functionalized molecules such as $\beta$-hydroxyketones [7-10], amino alcohols or amino acids [11-17], etc. The multifunctionalized cyclic amino acids - e.g., the antibiotic Oryzoxymycin [18-21], the antiviral agents Tamiflu [22-33], Zanamivir and 2,3-didehydro-2-deoxy- $N$-acetylneuraminic acid (DANA) [34-38] - are bioactive derivatives of great significance for medicinal chemistry. A promising neuraminidase inhibitor, BCX-1812 (Peramivir), is currently under evaluation in clinical trials [39-45] (Figure 1). A series of Peramivir analogues has recently been investigated as potential antiviral agents $[46,47]$.

\section{Results and Discussion}

We recently reported a regio- and stereoselective procedure for the formation of a series of isoxazoline-fused cispentacin and transpentacin regio- and stereoisomers (2-6) from bicyclic $\beta$-lactam 1 [48,49] (Scheme 1). The syntheses consisted of a dipolar cycloaddition of nitrile oxide (generated with $\mathrm{Boc}_{2} \mathrm{O}$, $\mathrm{Et}_{3} \mathrm{~N}$ and DMAP) to the olefinic bond of cis-ethyl 2-aminocyclopent-3-enecarboxylate derived from 1 , during which the isoxazoline-fused amino ester regio- and stereoisomers ( 2 and 

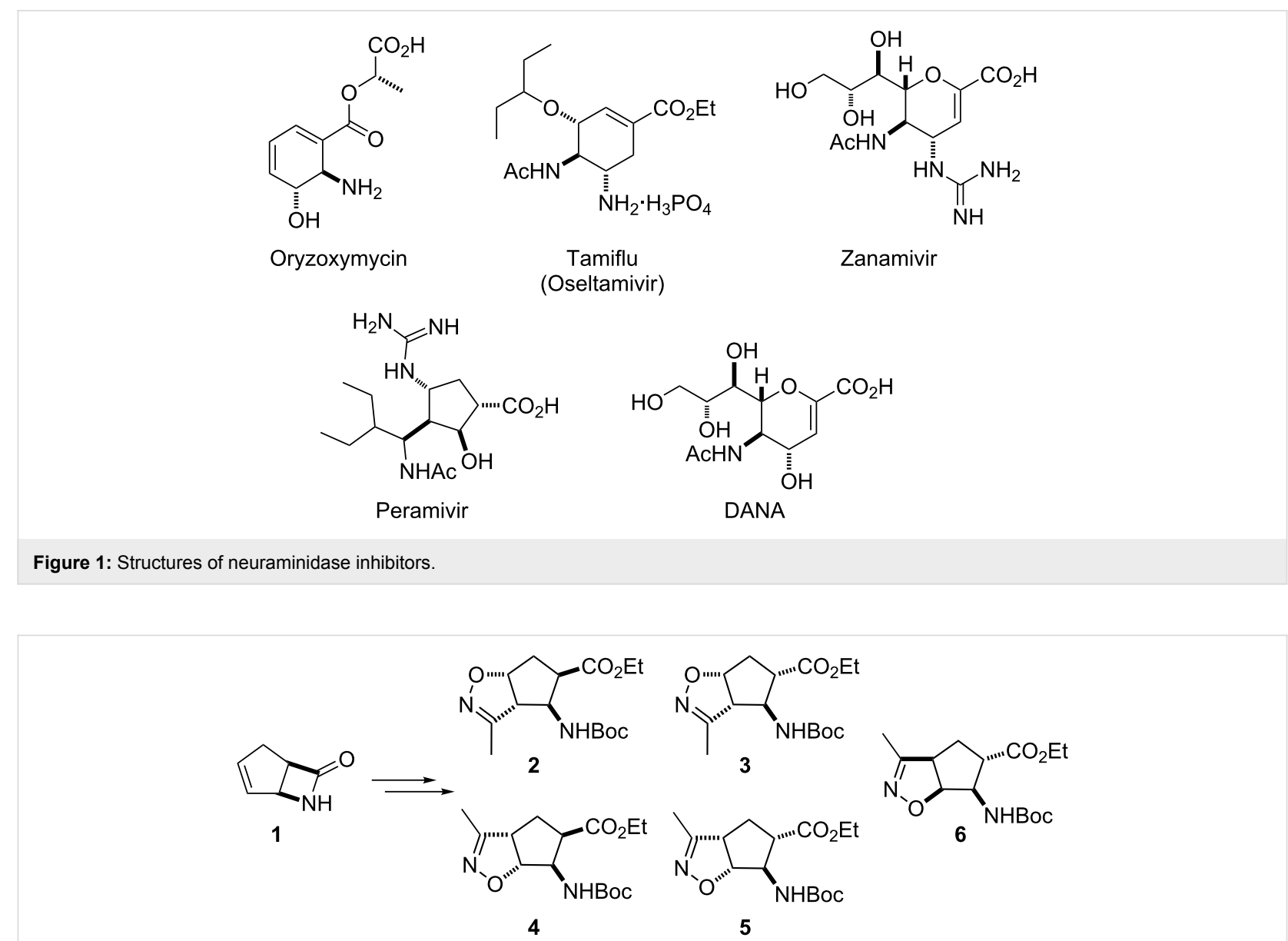

Scheme 1: Isoxazoline-fused $\beta$-aminocyclopentanecarboxylate regio- and stereoisomers [8].

4) were formed, then separated and isolated. The cycloaddition of nitrile oxide to trans-ethyl 2-aminocyclopent-3-enecarboxylate under similar conditions proceeded selectively with the formation of $\mathbf{6}$. Epimerization of $\mathbf{2}$ and $\mathbf{4}$ afforded trans derivatives $\mathbf{3}$ and $\mathbf{5}[48,49]$.

Since isoxazoline-functionalized molecules are excellent precursors for the construction of different functional groups through reductive ring cleavage, our recent aim was to synthesize highly functionalized $\beta$-aminocyclopentanecarboxylate regio- and stereoisomers from the earlier prepared isoxazolinefused cispentacin and transpentacin derivatives.

A number of methods are known for the reductive opening of the isoxazoline ring: Catalytic hydrogenation or reduction with $\mathrm{Fe}$ in the presence of $\mathrm{NH}_{4} \mathrm{Cl}, \mathrm{NaBH}_{4}, \mathrm{LiAlH}_{4}$, Raney $\mathrm{Ni}$, $\mathrm{BH}_{3} \cdot \mathrm{THF}$, or $\mathrm{SmI}_{2} / \mathrm{B}(\mathrm{OH})_{3} / \mathrm{H}_{2} \mathrm{O}$ [7-17].

For the reduction, we selected model compound $\mathbf{2}$ from earlier prepared isoxazoline-fused cispentacin stereoisomers to execute the reduction under different conditions. The isoxazoline-fused derivative was treated with the above-mentioned reducing agents. Unfortunately, neither transformation nor isoxazoline opening with ester reduction was observed. When the reduction was carried out with $\mathrm{NaBH}_{4}$ in EtOH, three products were obtained: The epimerized isoxazoline-fused amino carboxylate 7 and amino alcohols 8 and 9 which were separated by chromatography and isolated (Scheme 2).

Thus, this reaction did not lead to the formation of highly functionalized isoxazoline ring-opened $\beta$-amino ester either. When ammonium formate in $\mathrm{EtOH}$ in the presence of $\mathrm{Pd} / \mathrm{C}$ was investigated for the reduction of $\mathbf{2}$, the ring opening resulted in carbonyl compound $\mathbf{1 0}$ in rather low yield through the corresponding hydroxyimine intermediate, followed by elimination and saturation (Scheme 3).

Combinations of $\mathrm{NaBH}_{4}$ (as a mild and selective reducing agent) with cobalt, nickel, iridium or rhodium halide have previously been employed for cleavage of the isoxazoline ring system, which is otherwise inert to $\mathrm{NaBH}_{4}$ without such metal halide additives [50]. Accordingly, we investigated the reduc- 


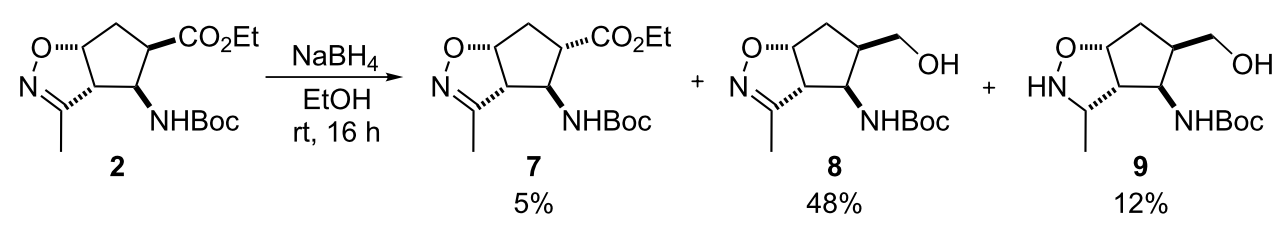

Scheme 2: Treatment of isoxazoline-fused amino ester 2 with $\mathrm{NaBH}_{4}$.

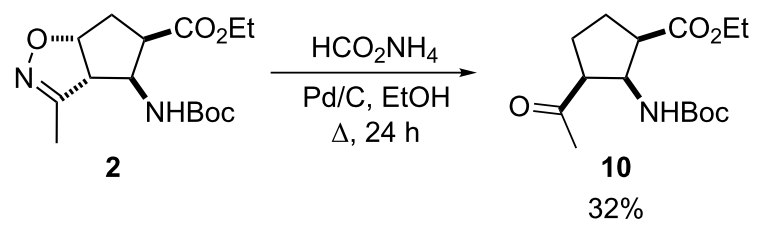

Scheme 3: Reduction with $\mathrm{Pd} / \mathrm{C}$ in the presence of $\mathrm{HCO}_{2} \mathrm{NH}_{4}$.

tion of isoxazoline-fused amino ester stereoisomers 2 [48,49] with $\mathrm{NaBH}_{4}$ in the presence of $\mathrm{NiCl}_{2}$ (Scheme 4), which was found to be a suitable reducing system.

The reduction carried out by adding $\mathrm{NaBH}_{4}$ to a mixture of $\mathrm{NiCl}_{2}$ and isoxazoline derivative 2 in $\mathrm{EtOH} / \mathrm{H}_{2} \mathrm{O}$, followed by amino group protection with $\mathrm{Boc}_{2} \mathrm{O}$, selectively afforded only isoxazoline-opened product $\mathbf{1 2}$ as a single diastereomer in good yield. The reaction was exothermic and deposited a black granular precipitate, reflecting the presence of metal boride. The product was purified by column chromatography and the structure of $\mathbf{1 2}$ was certified by X-ray analysis (Figure 2).

The isoxazoline opening occurred with the formation of a new stereocenter at a one-carbon distance from C-3. In accordance with earlier results [39-47], the hydrogenation of the isoxazoline proceeded through hydrogen attack from the carbamate side (cis to -NHBoc) of the cyclopentane skeleton. This was confirmed by X-ray analysis of $\mathbf{1 2}$.

In order to increase the number of multifunctionalized amino ester stereoisomers, we next examined the reductions of isoxazoline-fused cispentacin and transpentacin stereoisomers (3-6)

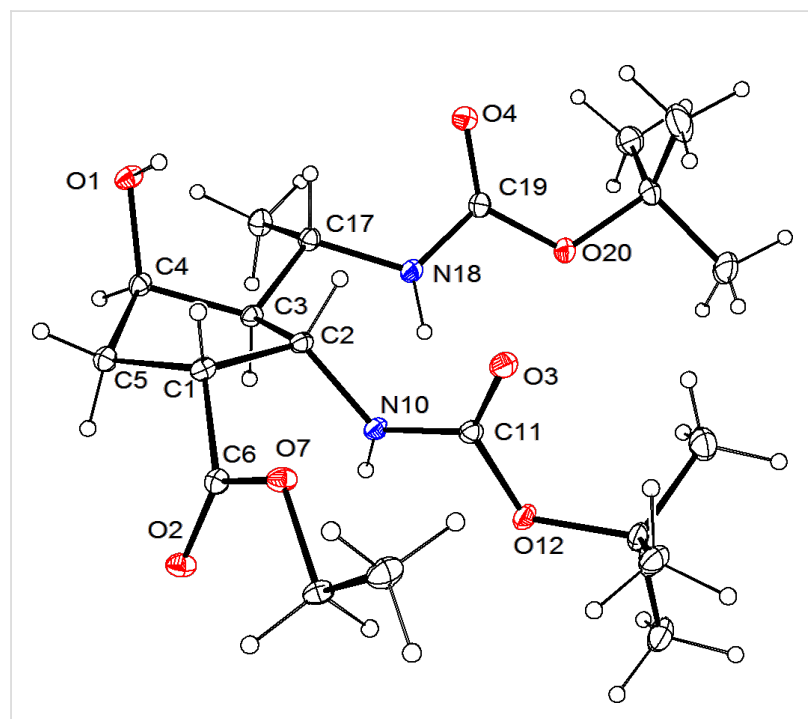

Figure 2: ORTEP diagram of 12 showing the atomic labeling scheme. The thermal ellipsoids are drawn at the $20 \%$ probability level.

[49]. Reactions were carried out similarly with $\mathrm{NaBH}_{4}$ in the presence of $\mathrm{NiCl}_{2}$ in $\mathrm{EtOH} / \mathrm{H}_{2} \mathrm{O}$ and led selectively to the corresponding multifunctionalized amino esters 13-16 in good yields (Scheme 5) as single diastereoisomers.

\section{Conclusion}

The present work has furnished a facile and efficient stereoselective reduction of isoxazoline-fused cyclic $\beta$-amino esters to multifunctionalized 2-aminocyclopentanecarboxylates through the use of $\mathrm{NaBH}_{4} / \mathrm{NiCl}_{2}$ as reducing agent. As Peramivir related derivatives, highly functionalized cyclic amino esters may be regarded as promising bioactive compounds.<smiles>CCOC1C[C@@H]2ON=C(C)[C@H]2[C@H]1NC(=O)OCc1ccccc1</smiles>

2

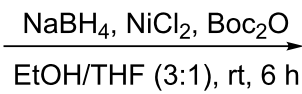

$\mathrm{EtOH} / \mathrm{THF}(3: 1), \mathrm{rt}, 6 \mathrm{~h}$<smiles>CCOC(=O)C1C[C@H](O)[C@H](C(C)NC(=O)OCc2ccccc2)C1NC(=O)OCc1ccccc1</smiles>

$(80 \%)$ 

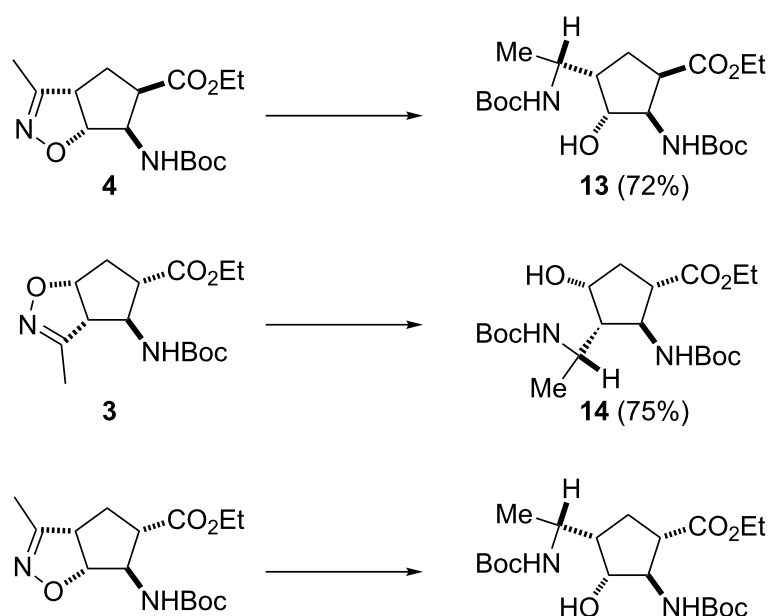

5

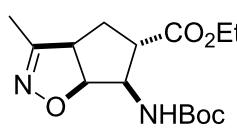

6

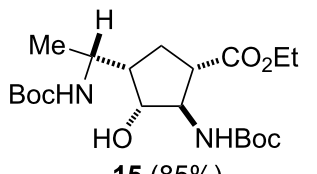

$15(85 \%)$

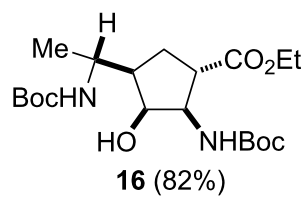

Scheme 5: Synthesis of multifunctionalized $\beta$-amino acid derivatives 13-16. Reaction conditions: $\mathrm{NaBH}_{4}, \mathrm{NiCl}_{2}, \mathrm{Boc}_{2} \mathrm{O}, \mathrm{EtOH} / \mathrm{H}_{2} \mathrm{O}, \mathrm{rt}, 6 \mathrm{~h}$.

\section{Experimental}

The chemicals were purchased from Aldrich. The solvents were used as received from the supplier. Melting points were determined with a Kofler apparatus. NMR spectra were recorded on a Bruker DRX $400 \mathrm{MHz}$ spectrometer in deuterated DMSO or $\mathrm{CDCl}_{3}$. Chemical shifts are expressed in ppm $(\delta)$ from the signal of internal tetramethylsilane. Mass spectra were recorded on a Finnigan MAT 95S spectrometer. Elemental analyses were recorded on a Perkin-Elmer CHNS-2400 Ser II Elemental Analyzer. FTIR spectra were recorded on a Perkin-Elmer Spectrum 100 instrument. Cycloadducts 2-6 were synthesized according to previously published procedures [8].

\section{General procedure for the synthesis of com- pounds 8 and 9}

To a solution of izoxazoline-fused $\beta$-aminocyclopentanecarboxylate $2(0.96 \mathrm{mmol})$ in dry EtOH $(15 \mathrm{~mL}) \mathrm{NaBH}_{4}$ $(2.88 \mathrm{mmol})$ was added and the reaction mixture was stirred under reflux for $16 \mathrm{~h}$. The reaction was quenched by the addition of $\mathrm{H}_{2} \mathrm{O}(10 \mathrm{~mL})$ and then, the mixture was concentrated under reduced pressure. The reaction mixture was diluted with $\mathrm{H}_{2} \mathrm{O}(20 \mathrm{~mL})$, washed with EtOAc $(3 \times 15 \mathrm{~mL})$, dried $\left(\mathrm{Na}_{2} \mathrm{SO}_{4}\right)$ and concentrated under reduced pressure. The crude residue was purified by column chromatography on silica gel ( $n$-hexane/EtOAc) giving 8 and 9.

\section{General procedure for the synthesis of $\mathbf{1 0}$}

To a stirred solution of isoxazoline-fused $\beta$-aminocyclopentanecarboxylate $2(1.6 \mathrm{mmol})$ in dry EtOH $(15 \mathrm{~mL}), \mathrm{HCOONH}_{4}$ $(3.2 \mathrm{mmol})$ and $\mathrm{Pd} / \mathrm{C}(0.10 \mathrm{~g})$ were added and the reaction mixture was stirred under reflux for $24 \mathrm{~h}$. The mixture was filtered through a celite pad and the filtrate was evaporated in vacuo. The crude residue was diluted with EtOAc $(30 \mathrm{~mL})$, washed with $\mathrm{H}_{2} \mathrm{O}(3 \times 15 \mathrm{~mL})$, dried over $\mathrm{Na}_{2} \mathrm{SO}_{4}$ and concentrated under reduced pressure. The residue was purified by column chromatography on silica gel ( $n$-hexane/EtOAc), giving $\mathbf{1 0}$.

\section{General procedure for isoxazoline ring opening}

To a stirred solution of isoxazoline-fused $\beta$-aminocyclopentanecarboxylates 2-6 $(0.96 \mathrm{mmol})$ in $8 \mathrm{~mL}$ of EtOH/THF (v:v = $3: 1), \mathrm{NiCl}_{2}(1.92 \mathrm{mmol})$ and $\mathrm{Boc}_{2} \mathrm{O}(1.92 \mathrm{mmol})$ were added. After stirring for $10 \mathrm{~min}, \mathrm{NaBH}_{4}(1.92 \mathrm{mmol})$ was added in portions. The reaction mixture was further stirred for $6 \mathrm{~h}$ at room temperature and the reaction was quenched by the addition of $\mathrm{H}_{2} \mathrm{O}(5 \mathrm{~mL})$. The reaction mixture was filtered through a celite pad and the filtrate was evaporated in vacuo. The crude residue was diluted with EtOAc $(30 \mathrm{~mL})$, washed with $\mathrm{H}_{2} \mathrm{O}$ $(3 \times 15 \mathrm{~mL})$, dried over $\mathrm{Na}_{2} \mathrm{SO}_{4}$, and concentrated under reduced pressure. The residue was purified by column chromatography on silica gel ( $n$-hexane/EtOAc), giving the corresponding reduced product.

tert-Butyl $(3 \mathrm{a} R *, 4 R *, 5 R *, 6 \mathrm{a} R *)$-[5-(hydroxymethyl)-3methyl-4,5,6,6a-tetrahydro-3a $H$-cyclopenta $[d]$ isoxazol-4yl]carbamate (8): Light-yellow oil; yield 48\% (124 mg); $R_{\mathrm{f}}$ 0.35 ( $n$-hexane/EtOAc); IR (KBr) $v / \mathrm{cm}^{-1}: 3344,3265,2979$, 1678, 1563, 1184; ${ }^{1} \mathrm{H}$ NMR (400 MHz, $\left.\mathrm{CDCl}_{3}\right) \delta 1.45$ (s, 3H, $\left.\mathrm{CH}_{3}\right), 1.56\left(\mathrm{~s}, 9 \mathrm{H}, \mathrm{CH}_{3}\right), 1.65-1.72\left(\mathrm{~m}, 2 \mathrm{H}, \mathrm{CH}_{2}\right), 2.19-2.25$ (m, 1H, H-5), 2.75-2.81 (m, 1H, H-3a), 3.19-3.25 (m, 1H, H-6a), 3.59-3.71 (m, 1H, H-4), 3.63-3.72 (m, 2H, $\left.\mathrm{CH}_{2}\right), 5.42$ (br s, 1H, N-H), OH group not observed - exchanged; ${ }^{13} \mathrm{C}$ NMR $\left(100 \mathrm{MHz}, \mathrm{CDCl}_{3}\right) \delta 16.0,28.6,30.2,32.5,43.0$, 44.4, 59.2, 63.9, 78.0, 155.2, 155.6; MS (ESI) $\mathrm{m} / \mathrm{z}: 293[\mathrm{M}+$ $\mathrm{Na}]^{+}$; Anal. calcd for $\mathrm{C}_{13} \mathrm{H}_{22} \mathrm{~N}_{2} \mathrm{O}_{4}: \mathrm{C}, 57.76 ; \mathrm{H}, 8.20 ; \mathrm{N}, 10.36$; found: $\mathrm{C}, 57.60 ; \mathrm{H}, 8.07 ; \mathrm{N}, 10.23$.

tert-Butyl $\left(3 S^{*}, 3 \mathrm{a} R *, 4 R *, 5 R *, 6 \mathrm{a} R *\right)$-[5-(hydroxymethyl)-3methylhexahydro-2H-cyclopenta $[d]$ isoxazol-4-yl]carbamate (9): Colorless oil; yield 12\% (31 mg); $R_{\mathrm{f}} 0.29$ ( $n$-hexane/ EtOAc); IR (KBr) $v / \mathrm{cm}^{-1}$ : 3460, 3331, 2978, 1683, 1531, 1174; ${ }^{1} \mathrm{H}$ NMR (400 MHz, $\left.\mathrm{CDCl}_{3}\right) \delta$ 0.98-1.05 (m, 3H, $\left.\mathrm{CH}_{3}\right), 1.36$ (s, $\left.9 \mathrm{H}, \mathrm{CH}_{3}\right), 1.55-1.75\left(\mathrm{~m}, 2 \mathrm{H}, \mathrm{CH}_{2}\right), 2.22-2.27$ (m, 1H, H-5), 2.38-2.47 (m, 1H, H-3a), 2.78-2.86 (m, 1H, H-3), 3.17-3.24 (m, 1H, H-6a), 3.59-3.69 (m, 1H, H-4), 3.36-3.68 (m, 2H, $\mathrm{CH}_{2}$ ), 5.32 (br s, 1H, N-H), 6.12 (br s, $\left.1 \mathrm{H}, \mathrm{N}-\mathrm{H}\right), \mathrm{OH}$ group not observed - exchanged; ${ }^{13} \mathrm{C} \mathrm{NMR}\left(100 \mathrm{MHz}, \mathrm{CDCl}_{3}\right) \delta 15.0$, 
27.1, 29.0, 35.8, 42.4, 51.7, 57.2, 62.6, 77.4, 80.4, 155.6; MS (ESI) $m / z: 295[\mathrm{M}+\mathrm{Na}]^{+}$; Anal. calcd for $\mathrm{C}_{13} \mathrm{H}_{24} \mathrm{~N}_{2} \mathrm{O}_{4}$ : C, 57.33; H, 8.88; N, 10.29; found: C, 57.20; H, 8.71; N, 10.42 .

Ethyl $\left(1 R^{*}, 2 S *, 3 S *\right)-3$-acetyl-2-(tert-butoxycarbonylamino)cyclopentanecarboxylate (10): White solid; yield $32 \%$ (153 mg); mp 109-110 ${ }^{\circ} \mathrm{C} ; R_{\mathrm{f}} 0.62$ (n-hexane/EtOAc); IR (KBr) $v / \mathrm{cm}^{-1}: 3354,2978,1716,1684,1531,1171 ;{ }^{1} \mathrm{H}$ NMR $(400$ $\left.\mathrm{MHz}, \mathrm{CDCl}_{3}\right) \delta 1.29\left(\mathrm{t}, J=7.54 \mathrm{~Hz}, 3 \mathrm{H}, \mathrm{CH}_{3}\right), 1.41(\mathrm{~s}, 9 \mathrm{H}$, $\left.\mathrm{CH}_{3}\right), 1.59-1.71\left(\mathrm{~m}, 2 \mathrm{H}, \mathrm{CH}_{2}\right), 1.74-1.95\left(\mathrm{~m}, 2 \mathrm{H}, \mathrm{CH}_{2}\right), 2.05$ (s, 3H, $\left.\mathrm{CH}_{3}\right), 2.83-2.97$ (m, 1H, H-1), 3.01-3.15 (m, 1H, H-3), 4.18-4.29 (m, 2H, $\left.\mathrm{OCH}_{2}\right), 4.31-4.44(\mathrm{~m}, 1 \mathrm{H}, \mathrm{H}-2), 5.76$ (br s, $1 \mathrm{H}, \mathrm{N}-\mathrm{H}) ;{ }^{13} \mathrm{C} \mathrm{NMR}\left(100 \mathrm{MHz}, \mathrm{CDCl}_{3}\right) \delta 13.98,20.05,25.76$, 29.31, 31.21, 43.97, 46.01, 52.70, 82.01, 155.67, 176.01, 206.52; MS (ESI) $\mathrm{m} / z: 322[\mathrm{M}+\mathrm{Na}]^{+}$; Anal. calcd for $\mathrm{C}_{15} \mathrm{H}_{25} \mathrm{NO}_{5}$ : C, 60.18; H, 8.42; N, 4.68; found: $\mathrm{C}, 60.05 ; \mathrm{H}$, $8.35 ; \mathrm{N}, 4.54$.

Ethyl $\left(1 R^{*}, 2 S^{*}, 3 S^{*}, 4 R^{*}\right)-2-\left(\right.$ tert-butoxycarbonyl)-3-(( $\left.S^{*}\right)-1-$ (tert-butoxycarbonyl)ethyl)-4-hydroxycyclopentanecarboxylate (12): White solid; yield 80\% (320 mg); mp 120-121 ${ }^{\circ} \mathrm{C} ; R_{\mathrm{f}}$ 0.22 ( $n$-hexane/EtOAc $1: 1)$; IR (KBr) $v / \mathrm{cm}^{-1}: 3457,3348$, 2982, 1720, 1698, 1531, 1160; ${ }^{1} \mathrm{H}$ NMR (400 MHz, DMSO) $\delta$ $0.96\left(\mathrm{t}, J=7.34 \mathrm{~Hz}, 3 \mathrm{H}, \mathrm{CH}_{3}\right), 1.27-1.33\left(\mathrm{~m}, 3 \mathrm{H}, \mathrm{CH}_{3}\right)$, 1.45-1.50 (m, 18H, CH 3$), 1.94-2.02\left(\mathrm{~m}, 2 \mathrm{H}, \mathrm{CH}_{2}\right), 2.07-2.16$ (m, 1H, H-4), 3.30-3.39 (m, 1H, H-1), 3.80-3.89 (m, 1H, CH), 4.13-4.23 (m, 2H, $\left.\mathrm{OCH}_{2}\right), 4.24-4.30(\mathrm{~m}, 1 \mathrm{H}, \mathrm{H}-2), 4.44-4.56$ (m, 1H, H-3), 5.28-5.35 (m, 1H, NH), 5.61-5.72 (m, 1H, NH), $\mathrm{OH}$ group not observed - exchanged; ${ }^{13} \mathrm{C}$ NMR $(100 \mathrm{MHz}$, $\left.\mathrm{CDCl}_{3}\right) \delta 11.7,14.6,28.8,28.9,29.3,30.1,31.8,37.3,44.6$, 51.1, 54.6, 61.2, 73.7, 80.1, 80.4, 155.0, 156.5, 172.0; MS (ESI) $m / z: 418[\mathrm{M}+2 \mathrm{H}]^{+}$; Anal. calcd for $\mathrm{C}_{20} \mathrm{H}_{36} \mathrm{~N}_{2} \mathrm{O}_{7}: \mathrm{C}, 57.67 ; \mathrm{H}$, 8.71 ; N, 6.73; found: C, 57,44; H, 8.86; N, 6.58.

Ethyl $\left(1 R^{*}, 2 R^{*}, 3 R^{*}, 4 S^{*}\right)-2$-(tert-butoxycarbonyl)-4-(( $\left.R^{*}\right)-1-$ (tert-butoxycarbonyl)ethyl)-3-hydroxycyclopentanecarboxylate (13): White solid; yield 72\% (288 mg); mp 129-130 ${ }^{\circ} \mathrm{C} ; R_{\mathrm{f}}$ 0.59 ( $n$-hexane/EtOAc 1:1); IR (KBr) $v / \mathrm{cm}^{-1}: 3479,3347$, $3353,1725,1685,1662,1531,1163 ;{ }^{1} \mathrm{H}$ NMR $(400 \mathrm{MHz}$, $\left.\mathrm{CDCl}_{3}\right) \delta 1.17-1.29\left(\mathrm{~m}, 6 \mathrm{H}, \mathrm{CH}_{3}\right), 1.40-1.46\left(\mathrm{~m}, 18 \mathrm{H}, \mathrm{CH}_{3}\right)$, 1.79-1.91 (m, 1H, $\left.\mathrm{CH}_{2}\right), 2.05-2.19\left(\mathrm{~m}, 2 \mathrm{H}, \mathrm{CH}_{2}, \mathrm{H}-1\right)$, 3.26-3.34 (m, 1H, H-4), 3.86-4.01 (m, 2H, H-2, CH), $4.08-4.19$ (m, 3H, $\mathrm{OCH}_{2}, \mathrm{H}-3$ ), 4.53 (br s, 1H, N-H), 5.05 (br s, $1 \mathrm{H}, \mathrm{N}-\mathrm{H}), \mathrm{OH}$ group not observed - exchanged; ${ }^{13} \mathrm{C}$ NMR (100 $\left.\mathrm{MHz}, \mathrm{CDCl}_{3}\right) \delta 14.6,21.1,28.4,28.7,28.8,44.0,46.6,60.5$, 61.2, 67.5, 77.6, 80.2, 86.4, 156.1, 156.4, 174.8; MS (ESI) $\mathrm{m} / \mathrm{z}$ : $418[\mathrm{M}+2 \mathrm{H}]^{+}$; Anal. calcd for $\mathrm{C}_{20} \mathrm{H}_{36} \mathrm{~N}_{2} \mathrm{O}_{7}$ : C, 57.67; H, 8.71; $\mathrm{N}, 6.73$; found: C, $57.50 ; \mathrm{H}, 8.98 ; \mathrm{N}, 6.39$.

Ethyl $\left(1 S^{*}, 2 S^{*}, 3 S^{*}, 4 R^{*}\right)$-2-(tert-butoxycarbonyl)-3-((S*)-1(tert-butoxycarbonyl)ethyl)-4-hydroxycyclopentanecarboxy- late (14): White solid; yield 75\% (300 mg); mp 144-145 ${ }^{\circ} \mathrm{C} ; R_{\mathrm{f}}$ 0.3 (n-hexane/EtOAc 1:1); IR (KBr) $v / \mathrm{cm}^{-1}: 3420,3363,2980$, $1692,1537,1185 ;{ }^{1} \mathrm{H} \mathrm{NMR}\left(400 \mathrm{MHz}, \mathrm{CDCl}_{3}\right) \delta 1.26-1.33(\mathrm{~m}$, $\left.6 \mathrm{H}, \mathrm{CH}_{3}\right), 1.43-1.48\left(\mathrm{~m}, 18 \mathrm{H}, \mathrm{CH}_{3}\right), 1.82-1.93\left(\mathrm{~m}, 1 \mathrm{H}, \mathrm{CH}_{2}\right)$, 1.98-2.15 (m, 1H, H-1), 2.24-2.36 (m, 1H, $\left.\mathrm{CH}_{2}\right), 2.76-2.89$ (m, 1H, H-3), 3.58-3.72 (m, 1H, H-4), 3.93-4.05 (m, 1H, H-2), 4.15-4.25 (m, 3H, $\left.\mathrm{OCH}_{2}, \mathrm{CH}\right), 4.87$ (br s, 1H, N-H), 5.09 (br s, $1 \mathrm{H}, \mathrm{N}-\mathrm{H}), \mathrm{OH}$ group not observed - exchanged; ${ }^{13} \mathrm{C}$ NMR (100 $\left.\mathrm{MHz}, \mathrm{CDCl}_{3}\right) \delta 14.5,21.4,28.8,28.9,35.9,45.7,49.1,52.3$, $54.5,58.3,73.4,80.1,152.5,156.8,172.6$; MS (ESI) $m / z: 418$ $[\mathrm{M}+2 \mathrm{H}]^{+}$; Anal. calcd for $\mathrm{C}_{20} \mathrm{H}_{36} \mathrm{~N}_{2} \mathrm{O}_{7}: \mathrm{C}, 57.67 ; \mathrm{H}, 8.71 ; \mathrm{N}$, 6.73; found: C, 57.41; H, 8.37; N, 6.59.

Ethyl $\left(1 S^{*}, 2 R^{*}, 3 R^{*}, 4 S^{*}\right)-2-\left(\right.$ tert-butoxycarbonyl)-4-(( $\left.R^{*}\right)-1-$ (tert-butoxycarbonyl)ethyl)-3-hydroxycyclopentanecarboxylate (15): White solid; yield $85 \%$ (340 mg); mp 141-142 ${ }^{\circ} \mathrm{C} ; R_{\mathrm{f}}$ 0.46 ( $n$-hexane/EtOAc 1:1); IR (KBr) v/ $\mathrm{cm}^{-1}: 3426,3378$, $3333,2979,1688,1718,1703,1522,1176 ;{ }^{1} \mathrm{H}$ NMR (400 $\left.\mathrm{MHz}, \mathrm{CDCl}_{3}\right) \delta 1.21-1.30\left(\mathrm{~m}, 6 \mathrm{H}, \mathrm{CH}_{3}\right), 1.40-1.46(\mathrm{~m}, 18 \mathrm{H}$, $\mathrm{CH}_{3}$ ), 1.84-1.97 (m, 2H, CH, $\left.\mathrm{H}-4\right), 2.03-2.20$ (m, 2H, $\mathrm{CH}_{2}$, $\mathrm{H}-1), 2.54$ (q, $J=9.10 \mathrm{~Hz}, 1 \mathrm{H}, \mathrm{H}-2$ ), 3.73-3.82 (m, 1H, H-3), $3.87-4.04(\mathrm{~m}, 2 \mathrm{H}, \mathrm{N}-\mathrm{H}, \mathrm{CH}), 4.10-4.22\left(\mathrm{~m}, 2 \mathrm{H}, \mathrm{OCH}_{2}\right), 4.83$ (br s, 1H, N-H), OH group not observed - exchanged; ${ }^{13} \mathrm{C}$ NMR $\left(100 \mathrm{MHz}, \mathrm{CDCl}_{3}\right) \delta 14.1,20.0,27.5,28.7,28.8$, 45.6, 46.1, 46.8, 60.9, 62.5, 78.1, 80.1, 80.3, 154.0, 156.4, 174.6; MS (ESI) $m / z: 418[\mathrm{M}+2 \mathrm{H}]^{+}$; Anal. calcd for $\mathrm{C}_{20} \mathrm{H}_{36} \mathrm{~N}_{2} \mathrm{O}_{7}$ : C, 57.67; H, 8.71; N, 6.73; found: $\mathrm{C}, 57.91 ; \mathrm{H}$, $8.46 ; \mathrm{N}, 6.58$.

Ethyl $\left(1 S^{*}, 2 R^{*}, 3 S^{*}, 4 R^{*}\right)-2-\left(\right.$ tert-butoxycarbonyl)-4-(( $\left.S^{*}\right)-1-$ (tert-butoxycarbonyl)ethyl)-3-hydroxycyclopentanecarboxylate (16): White solid; yield $82 \%$ (328 mg); mp 166-167 ${ }^{\circ} \mathrm{C} ; R_{\mathrm{f}}$ 0.32 ( $n$-hexane/EtOAc $1: 1$ ); IR (KBr) $v / \mathrm{cm}^{-1}: 3485,3368$, 3353, 2975, 1733, 1681, 1667, 1533, 1167; ${ }^{1} \mathrm{H}$ NMR (400 $\left.\mathrm{MHz}, \mathrm{CDCl}_{3}\right) \delta 1.17-1.31\left(\mathrm{~m}, 6 \mathrm{H}, \mathrm{CH}_{3}\right), 1.38-1.46(\mathrm{~m}, 18 \mathrm{H}$, $\left.\mathrm{CH}_{3}\right), 1.79-2.15$ (m, 3H, CH $\left.2, \mathrm{H}-1, \mathrm{H}-4\right), 2.72-2.87$ (m, $1 \mathrm{H}$, $\mathrm{CH}_{2}$ ), 3.77-4.03 (m, 1H, CH), 4.06-4.23 (m, 4H, H-2, H-3, $\mathrm{OCH}_{2}$ ), 4.37-4.48 (m, 1H, N-H), 4.88 (br s, 1H, N-H), OH group not observed - exchanged; ${ }^{13} \mathrm{C} \mathrm{NMR}\left(100 \mathrm{MHz}, \mathrm{CDCl}_{3}\right)$ 14.6, 21.6, 28.7, 28.8, 47.2, 49.0, 59.9, 61.2, 61.6, 69.4, 74.7, 80.0, 85.9, 117.5, 156.1, 158.8, 171.3; MS (ESI) $\mathrm{m} / \mathrm{z}: 418[\mathrm{M}+$ $2 \mathrm{H}]^{+}$; Anal. calcd for $\mathrm{C}_{20} \mathrm{H}_{36} \mathrm{~N}_{2} \mathrm{O}_{7}$ : C, 57.67; $\mathrm{H}, 8.71$; N, 6.73; found: $\mathrm{C}, 57.43 ; \mathrm{H}, 8.40 ; \mathrm{N}, 6.95$.

X-ray crystallographic study of 12: Crystallographic data were collected at $123 \mathrm{~K}$ with a Nonius-Kappa CCD area detector diffractometer, using graphite-monochromatized Mo $K_{a}$ radiation $(\lambda=0.71073 \AA)$ as reported earlier [51]. Crystal data for $12, \mathrm{C}_{20} \mathrm{H}_{36} \mathrm{~N}_{2} \mathrm{O}_{7}, M_{r}=416.51$, triclinic, space group $P-1$ (no. 2), $a=9.3765(2), b=13.7078(4), c=$ 18.7792(4) $\AA, \alpha=96.609(2), \beta=95.261(1), \gamma=100.965(1), V=$ 
2337.9(1) $\AA^{3}, T=123 \mathrm{~K}, Z=4, \mu\left(\mathrm{Mo} \mathrm{K}_{\alpha}\right)=0.089 \mathrm{~mm}^{-1}, 9120$ unique reflections $\left(R_{\text {int }}=0.034\right)$ which were used in calculations. The final $R l$ (for the data with $F^{2}>2 \delta\left(F^{2}\right)$ was 0.042 and $w R 2\left(F^{2}\right)$ (all data) was 0.111 .

The SHELXL-97 program [52] was used to solve the structure by direct methods and to perform full-matrix, least-squares refinements on $F^{2}$. The unit cell of $\mathbf{1 2}$ contains two molecules with slightly different conformations. The $\mathrm{CH}$ hydrogen atoms were included at fixed distances from their host atoms with fixed displacement parameters. The $\mathrm{NH}$ and $\mathrm{OH}$ hydrogen atoms were refined isotropically. The deposition number CCDC 845835 contains the supplementary crystallographic data for this paper. These data can be obtained free of charge at http:// www.ccdc.cam.ac.uk/conts/retrieving.html [or from the Cambridge Crystallographic Data Centre, 12 Union Road, Cambridge CB2 1EZ, UK; Fax: (internat.) +44-1223-336-033; Email: deposit@ccdc.cam.ac.uk].

\section{Acknowledgements}

We are grateful to the Hungarian Research Foundation (OTKA No. T81371) for financial support and acknowledge the receipt of a Bolyai János Fellowship for Loránd Kiss. We also thank TAMOP-4.2.1/B-09/1/KONV-2010-0005.

\section{References}

1. Pinto, A.; Conti, P.; De Amici, M.; Tamborini, L.; Grazioso, G.; Colleoni, S.; Mennini, T.; Gobbi, M.; De Micheli, C. Tetrahedron: Asymmetry 2008, 19, 867-875. doi:10.1016/j.tetasy.2008.03.001

2. Conti, P.; Caligiuri, A.; Pinto, A.; Roda, G.; Tamborini, L.; Nielsen, B.; Madsen, U.; Frydenvang, K.; Colombo, A.; De Micheli, C. Eur. J. Med. Chem. 2007, 42, 1059-1068. doi:10.1016/j.ejmech.2007.01.013

3. Roda, G.; Conti, P.; De Amici, M.; He, J.; Polavaropu, P. L.; De Micheli, C. Tetrahedron: Asymmetry 2004, 15, 3079-3090. doi:10.1016/j.tetasy.2004.07.037

4. Conti, P.; De Amici, M.; Di Ventimiglia, S. J.; StensbøI, T. B.; Madsen, U.; Bräuner-Osborne, H.; Russo, E.; De Sarro, G.; Bruno, G.; De Micheli, C. J. Med. Chem. 2003, 46, 3102-3108. doi:10.1021/jm0308085

5. Park, K.-H.; Olmstead, M. M.; Kurth, M. J. J. Org. Chem. 1998, 63, 113-117. doi:10.1021/jo9714831

6. Pinto, A.; Conti, P.; Grazioso, G.; Tamborini, L.; Madsen, U.; Nielsen, B.; De Micheli, C. Eur. J. Med. Chem. 2011, 46, 787-793. doi:10.1016/j.ejmech.2010.12.020

7. Bode, J. W.; Carreire, E. M. Org. Lett. 2001, 3, 1587-1590. doi:10.1021/ol015885d

8. Bode, J. W.; Fraefel, N.; Muri, D.; Carreira, E. M. Angew. Chem., Int. Ed. 2001, 40, 2082-2085. doi:10.1002/1521-3773(20010601)40:11<2082::AID-ANIE2082>3.0.CO $; 2-1$

9. Jiang, D.; Chen, Y. J. Org. Chem. 2008, 73, 9181-9183. doi:10.1021/jo801831c
10. Tang, S.; He, J.; Sun, Y.; He, L.; She, X. J. Org. Chem. 2010, 75, 1961-1966. doi:10.1021/jo1000065

11. Marotta, E.; Micheloni, L. M.; Scardovi, N.; Righi, P. Org. Lett. 2001, 3, 727-729. doi:10.1021/ol0070379

12. Scott, J. P.; Oliver, S. F.; Brands, K. M. J.; Brewer, S. E.; Davies, A. J.; Gibb, A. D.; Hands, D.; Keen, S. P.; Sheen, F. J.; Reamer, R. A.; Wilson, R. D.; Dolling, U.-H. J. Org. Chem. 2006, 71, 3086-3092. doi:10.1021/jo060033i

13. Maimone, T. J.; Shi, J.; Ashida, S.; Baran, P. S. J. Am. Chem. Soc. 2009, 131, 17066-17067. doi:10.1021/ja908194b

14. Minter, A. R.; Fuller, A. A.; Mapp, A. K. J. Am. Chem. Soc. 2003, 125, 6846-6847. doi:10.1021/ja0298747

15. Fuller, A. A.; Chen, B.; Minter, A. R.; Mapp, A. K. J. Am. Chem. Soc. 2005, 127, 5376-5383. doi:10.1021/ja0431713

16. Sewald, N. Angew. Chem., Int. Ed. 2003, 42, 5794-5795. doi:10.1002/anie.200301692

17. Tokizane, M.; Sato, K.; Ohta, T.; Ito, Y. Tetrahedron: Asymmetry 2008, 19, 2519-2528. doi:10.1016/j.tetasy.2008.11.005

18. Palkó, M.; Kiss, L.; Fülöp, F. Curr. Med. Chem. 2005, 12, 3063-3083. doi:10.2174/092986705774933443

19. Kiss, L.; Forró, E.; Fülöp, F. Synthesis of carbocyclic $\beta$-amino acids. In Amino Acids, Peptides and Proteins in Organic Chemistry; Hughes, A. B., Ed.; Wiley-VCH: Weinheim, Germany, 2009; Vol. 1, pp 367-409.

20. Kiss, L.; Fülöp, F. Synlett 2010, 1302-1314. doi:10.1055/s-0029-1219821

21. Fülöp, F. Chem. Rev. 2001, 101, 2181-2204. doi:10.1021/cr000456z 22. Ishikawa, H.; Suzuki, T.; Orita, H.; Uchimaru, T.; Hayashi, Y. Chem.-Eur. J. 2010, 16, 12616-12626. doi:10.1002/chem.201001108

23. Ko, J. S.; Keum, J. E.; Ko, S. Y. J. Org. Chem. 2010, 75, 7006-7009. doi:10.1021/jo101517g

24. Karpf, M.; Trussardi, R. Angew. Chem., Int. Ed. 2009, 48, 5760-5762. doi:10.1002/anie.200901561

25. Satoh, N.; Akiba, T.; Yokoshima, S.; Fukuyama, T. Tetrahedron 2009, 65, 3239-3245. doi:10.1016/j.tet.2008.09.103

26. Ishikawa, H.; Suzuki, T.; Hayashi, Y. Angew. Chem., Int. Ed. 2009, 48, 1304-1307. doi:10.1002/anie.200804883

27. Sullivan, B.; Carrera, I.; Drouin, M.; Hudlicky, T. Angew. Chem., Int. Ed 2009, 48, 4229-4231. doi:10.1002/anie.200901345

28. Trost, B. M.; Zhang, T. Angew. Chem., Int. Ed. 2008, 47, 3759-3761. doi:10.1002/anie.200800282

29. Zhu, S.; Yu, S.; Wang, Y.; Ma, D. Angew. Chem., Int. Ed. 2010, 49, 4656-4660. doi:10.1002/anie.201001644

30. Mohan, S.; McAtamney, S.; Haselhorst, T.; von Itzstein, M.; Pinto, B. M. J. Med. Chem. 2010, 53, 7377-7391. doi:10.1021/jm100822f

31. Kamimura, A.; Nakano, T. J. Org. Chem. 2010, 75, 3133-3136. doi:10.1021/jo1002856

32. Nie, L.-D.; Shi, X.-X.; Ko, K. H.; Lu, W.-D. J. Org. Chem. 2009, 74, 3970-3973. doi:10.1021/jo900218k

33. Osato, H.; Jones, I. L.; Chen, A.; Chai, C. L. L. Org. Lett. 2010, 12, 60-63. doi:10.1021/ol9024716

34. Wena, W.-H.; Wang, S.-Y.; Tsai, K.-C.; Cheng, Y.-S. E.; Yang, A.-S.; Fang, J.-M.; Wong, C.-H. Bioorg. Med. Chem. 2010, 18, 4074-4084. doi:10.1016/j.bmc.2010.04.010

35. Xu, G.; Kiefel, M. J.; Wilson, J. C.; Andrew, P. W.; Oggioni, M. R.; Taylor, G. L. J. Am. Chem. Soc. 2011, 133, 1718-1721. doi:10.1021/ja110733q 
36. Calveras, J.; Nagai, Y.; Sultana, I.; Ueda, Y.; Higashi, T.; Shoji, M.; Sugai, T. Tetrahedron 2010, 66, 4284-4291.

doi:10.1016/j.tet.2010.04.045

37. Honda, T.; Kubo, S.; Masuda, T.; Arai, M.; Kobayashi, Y.; Yamashita, M. Bioorg. Med. Chem. Lett. 2009, 19, 2938-2940. doi:10.1016/j.bmcl.2009.04.067

38. Soulé, J.-F.; Mathieu, A.; Norsikian, S.; Beau, J.-M. Org. Lett. 2010, 12, 5322-5325. doi:10.1021/ol102326b

39. Sorbera, L. A.; Graul, A.; Castaner, J. Drugs Future 2000, 25 , 249-251. doi:10.1358/dof.2000.025.03.565302

40. Babu, Y. S.; Chand, P.; Bantia, S.; Kotian, P.; Dehghani, A.; El-Kattan, Y.; Lin, T.-H.; Hutchison, T. L.; Elliott, A. J.; Parker, C. D.; Ananth, S. L.; Horn, L. L.; Laver, G. W.; Montgomery, J. A. J. Med. Chem. 2000, 43, 3482-3486. doi:10.1021/jm0002679

41. Chand, P.; Kotian, P. L.; Dehghani, A.; El-Kattan, Y.; Lin, T.-H.; Hutchison, T. L.; Babu, Y. S.; Bantia, S.; Elliott, A. J.; Montgomery, J. A. J. Med. Chem. 2001, 44, 4379-4392. doi:10.1021/jm010277p

42. Chand, P.; Babu, Y. S.; Bantia, S.; Rowland, S.; Dehghani, A.; Kotian, P. L.; Hutchison, T. L.; Ali, S.; Brouillette, W.; El-Kattan, Y.; Lin, T.-H. J. Med. Chem. 2004, 47, 1919-1929. doi:10.1021/jm0303406

43. Lü, W. J.; Chen, Y. L.; Ma, W. P.; Zhang, X. Y.; Luan, F.; Liu, M. C.; Chen, X. G.; Hu, Z. D. Eur. J. Med. Chem. 2008, 43, 569-576. doi:10.1016/j.ejmech.2007.04.011

44. Oakley, A. J.; Barrett, S.; Peat, T. S.; Newman, J.; Streltsov, V. A.; Waddington, L.; Saito, T.; Tashiro, M.; McKimm-Breschkin, J. L. J. Med. Chem. 2010, 53, 6421-6431. doi:10.1021/jm100621s

45. Chand, P.; Bantia, S.; Kotian, P. L.; El-Kattan, Y.; Lin, T.-H.; Babu, Y. S. Bioorg. Med. Chem. 2005, 13, 4071-4077. doi:10.1016/j.bmc.2005.03.048

46. Cui, Y.; Jiao, Z.; Gong, J.; Yu, Q.; Zheng, X.; Quan, J.; Luo, M.; Yang, Z. Org. Lett. 2010, 12, 4-7. doi:10.1021/ol902438f

47. Yi, X.; Guo, Z.; Chu, F. M. Bioorg. Med. Chem. 2003, 11, 1465-1474. doi:10.1016/S0968-0896(02)00602-8

48. Kiss, L.; Nonn, M.; Forró, E.; Sillanpää, R.; Fülöp, F. Tetrahedron Lett. 2009, 50, 2605-2608. doi:10.1016/j.tetlet.2009.03.119

49. Nonn, M.; Kiss, L.; Forró, E.; Mucsi, Z.; Fülöp, F. Tetrahedron 2011, 67, 4079-4085. doi:10.1016/j.tet.2011.04.005

50. Jiang, H.; Elsner, P.; Jensen, K. L.; Falcicchio, A.; Marcos, V.; Jørgensen, K. A. Angew. Chem., Int. Ed. 2009, 48, 6844-6848. doi:10.1002/anie.200901446

51. Kanizsai, I.; Szakonyi, Z.; Sillanpää, R.; D'hooghe, M.; De Kimpe, N.; Fülöp, F. Tetrahedron: Asymmetry 2006, 17, 2857-2863. doi:10.1016/j.tetasy.2006.11.006

52. Sheldrick, G. M. Acta Crystallogr., Sect. A 2008, 64, 112-122. doi:10.1107/S0108767307043930

\section{License and Terms}

This is an Open Access article under the terms of the Creative Commons Attribution License

(http://creativecommons.org/licenses/by/2.0), which permits unrestricted use, distribution, and reproduction in any medium, provided the original work is properly cited.

The license is subject to the Beilstein Journal of Organic Chemistry terms and conditions:

(http://www.beilstein-journals.org/bjoc)

The definitive version of this article is the electronic one which can be found at:

doi: $10.3762 /$ bjoc. 8.10 
IV. 


\title{
Izoxazolin gyürüvel kondenzált ciszpentacin származékok szintézise
}

\author{
NONN Melinda ${ }^{\mathrm{a}}$, KISS Loránd ${ }^{\mathrm{a}}$, FORRÓ Enikő ${ }^{\mathrm{a}}$, SILANPÄÄ REIJO ${ }^{\mathrm{b}}$, MUCSI Zoltán $^{\mathrm{c}}$, \\ FÜLÖP Ferenc ${ }^{\mathrm{a}^{*}}$ \\ ${ }^{a}$ Szegedi Tudományegyetem, Gyógyszerésztudományi Kar, Gyógyszerkémiai Intézet, Eötvös u. 6, 6720, Szeged, \\ Magyarország

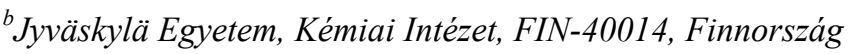

${ }^{c}$ Szegedi Tudományegyetem, Kémiai Informatikai Intézet, 6725, Szeged, Magyarország

\section{Bevezetés}

$\mathrm{Az}$ izoxazolin gyürüt tartalmazó vegyületek számos képviselője különböző biológiai (influenzaellenes, antifungális) hatással rendelkezik ${ }^{1}$. Izoxazolinváz kiépítésére alkalmazható egyik módszer a nitril-oxidok alkénekre történő 1,3-dipoláros cikloaddíciója ${ }^{2}$. Nitriloxidok in situ generálására legismertebb eljárások a Mukaiyama módszer, amely primer nitroalkánok dehidratációján alapszik $^{3}$, illetve a Huisgen módszer, a hidroximoil-kloridok bázis indukált dehidrohalogénezése ${ }^{4}$. A ciklusos $\alpha$ - vagy $\gamma$-aminosavszármazékokra nitriloxidokkal végrehajtott cikloaddíciók biológiailag aktív vegyületek szintéziséhez vezettek ${ }^{5}$. Ciklopenténvázas $\gamma$ aminosavakra történő sztereoszelektív cikloaddícióval különböző multiszubsztituált antivirális hatású származékot állítottak elö ${ }^{6}$. Farmakológiai hatásuknak köszönhetően a ciklusos $\beta$-aminosavakra az elmúlt években egyre nagyobb figyelem irányult ${ }^{7}$. A természetben elöforduló ciszpentacin [(1R,2S)-2-amino-1-ciklopentánkarbonsav], valamint az icofungipen $[(1 R, 2 S)$-2-amino-4-metilénciklopentánkarbonsav], baktériumellenes és antifungális hatású vegyületek ${ }^{7 \mathrm{~b}}$. A ciklusos $\beta$-aminosavakat széles körben alkalmazzák újtípusú peptidek szintézisére. Ezen kívül, a $\beta$-aminosavak különböző természetes vegyületek komponensei, valamint potenciális gyógyszervegyületek és heterociklusok építőelemeiként is szolgálnak ${ }^{8}$. Számos multifunkciós ciklusos aminosavszármazék (Oseltamivir, Zanamivir, Peramivir) különböző biológiai hatással rendelkezik ${ }^{7 \mathrm{~g}} \mathrm{~A}$ cikloalkénvázas $\beta$-aminosavak kettős kötése lehetőséget nyújt újabb funkciós csoportok szelektív kialakítására. Kutatócsoportunkban különböző szelektív funkcionalizálási technikákat alkalmazva hidroxi, fluor, dihidroxi, amino vagy azid funkciókat alakítottak ki $\beta$-aminosavak vázán. Kutatómunkánk célja a nitril-oxidok 1,3-dipoláros cikloaddíciójával izoxazolingyürűvel kondenzált újtípusú $\beta$-aminosav származékok regio- és sztereoszelektív szintézise volt.

\section{Eredmények}

\subsection{Izoxazolin gyürüvel kondenzált ciszpentacin származékok előállítása}

Munkánk első részében a terc-butoxikarbonil (Boc), illetve benzoil (COPh) csoporttal védett etil-cisz-2aminociklopent-3-énkarboxilátra (1a, 1b) terveztük végrehajtani a cikloaddíciót. Nitril-oxid generálására nitroetánt, vízelvonószerként terc-butoxikarbonil-anhidridet $\left(\mathrm{Boc}_{2} \mathrm{O}\right)$, bázisként pedig 4-dimetilaminopiridint (DMAP), alkalmaztunk. E reakciókat szobahőmérsékleten végeztük, THF oldószerben (1. ábra).

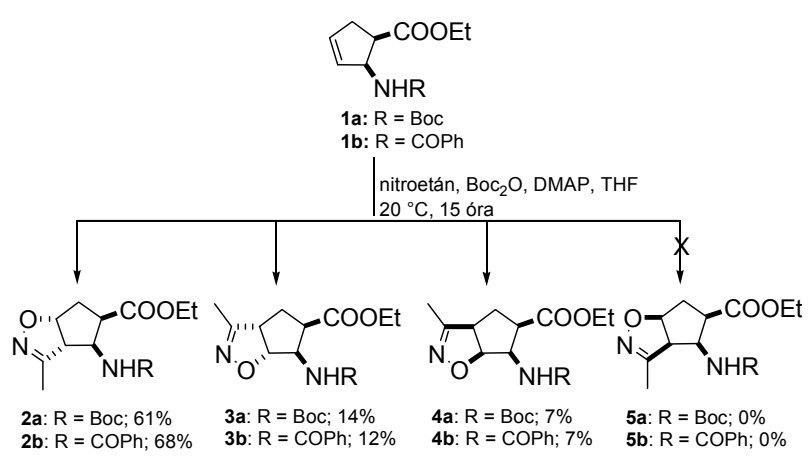

1. Ábra. Nitroetánból generált nitril-oxid 1,3- dipoláros cikloaddíciója etil-cisz-2-aminociklopent-3-énkarboxilátra

A reakciókban a lehetséges négy regio- és sztereoizomerből három izoxazolingyürüvel kondenzált származék keletkezett (2a, 2b; 3a, 3b; 4a, 4b). Az izomereket kromatográfiás módszerrel választottuk el. A vegyületek szerkezetét ${ }^{1} \mathrm{H}-\mathrm{NMR},{ }^{13} \mathrm{C}-\mathrm{NMR}$, COSY, NOESY, HSQC spektroszkópiai módszerekkel állapítottuk meg. A legnagyobb termeléssel képződő $\mathbf{2 b}$ termék szerkezetét röntgendiffrakciós méréssel is igazoltuk (2. ábra).

\footnotetext{
*Fülöp Ferenc. Tel.: (36)-62-545-462; fax: (36)-62-545-705; e-mail: fulop@pharm.u-szeged.hu
} 


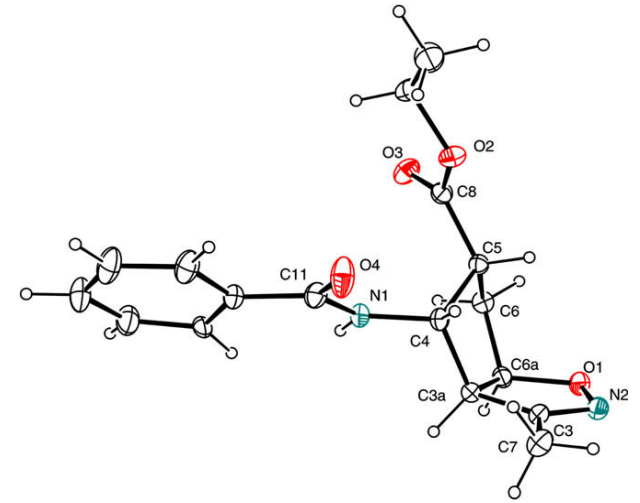

2. Ábra. A 2b vegyület röntgendiffrakciós képe

A 2a, 2b és 3a, 3b vegyületek esetében az izoxazolin gyürü az észter, illetve amino funkciókhoz viszonyítva transz, míg a minor termékben $(\mathbf{4 a}, \mathbf{4 b})$ cisz térállású. A major termékben (2a, 2b) az izoxazolingyürüben lévő oxigénatom távolabb esik a karbamát, illetve amid funkcióktól. Ez a szelektivitás a nitrogén elektronszívó hatásával magyarázható, mely szerint a 4-es szénatomon lecsökken az elektronsürüség, és a dipol reagens oxigénje erre a szénatomra támad. A nitril-oxid képzését a homológ 1nitropropánnal is elvégeztük, majd a korábbi reakciókörülményeket alkalmazva végrehajtottuk a cikloaddíciót miközben szintén három izoxazolinvázas izomer képződött (3. és 4. ábra). A termékek aránya megközelítőleg hasonló volt, mint a korábbi reakcióban.

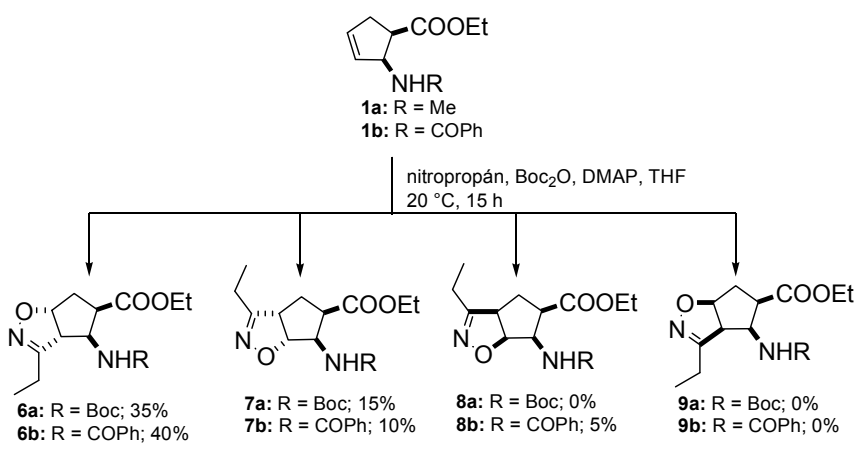

3. Ábra. Nitropropánból képzett nitril-oxid 1,3-dipoláros cikloaddíciója etil-cisz-2-aminociklopent-3-énkarboxilátra

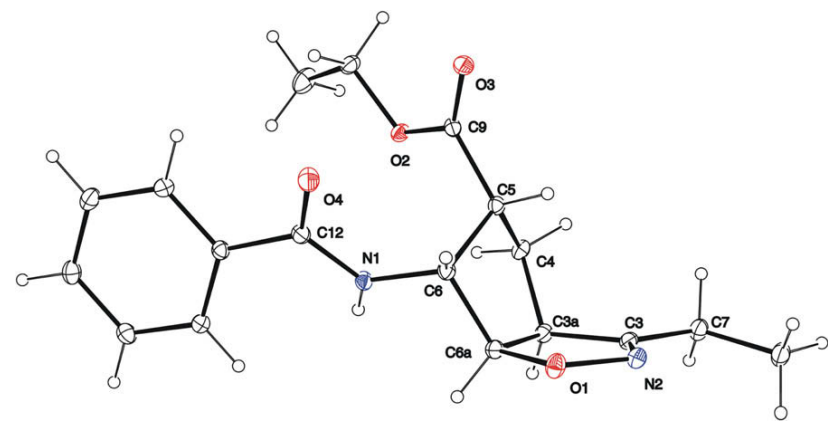

4. Ábra. A $6 \mathbf{b}$ vegyület röntgendiffrakciós képe

Ebben az esetben is a legnagyobb termeléssel képződő $\mathbf{6}$ termékben az izoxazolin gyürü transz térállású az észter, illetve amino funkciókhoz viszonyítva, valamint az izoxazolin gyürü oxigénatomja távolabb esik a karbamát, illetve amid funkciótól. E cikloaddíciós termékeket enantiomertiszta formában is elöállítottuk az optikailag aktív etil-cisz-2-aminociklopent-3-énkarboxilátból [(-)-1] kiindulva, amit a racém $\beta$-laktám Candida antartica $B$ Lipáz által katalizált enantioszelktív gyürünyitásával állítottunk elő. $\mathrm{Az}$ 1. és 3. ábrán bemutatott reakciókörülményeket alkalmazva a (-)-1 enantiomertiszta vegyületre megkaptuk az optikailag aktív izoxazolingyürüvel kondenzált $\beta$-aminosavkarboxilátokat $[(-)-2 a,(-)-3 a,(-)-4 a,(-)-6 a,(-)-7 a](5 . \text { ábra })^{9}$.

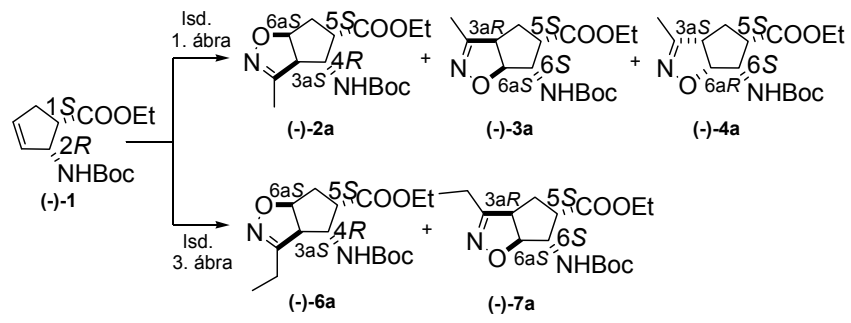

5. Ábra. Enantiomertiszta izoxazolingyürủvel kondenzált ciszpentacin származékok szintézise

\subsection{Izoxazolingyürüvel kondenzált ciszpentacin származékok szelektív szintézise}

Az elöbbi reakciók során - annak ellenére, hogy különböző izoxazolingyürüvel kondenzált ciszpentacin származékok regio- és sztereoizomerjeit sikerült előállítanunk - nem értünk el 100\%-os regio- és sztereoszelektivitást. Ezért a cikloaddíciós reakciókat elvégeztük fenilizocianát (PhNCO) vízelvonószer és trietilamin (TEA) bázis jelenlétében, THF oldószerben, 65 ${ }^{\circ} \mathrm{C}$-on (6. ábra).

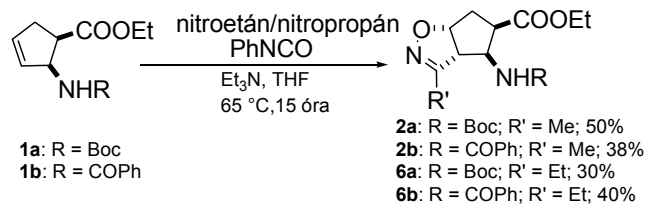

6. Ábra. Izoxazolingyürüvel kondenzált ciszpentacin származékok regioés sztereoszelektív szintézise

Meglepő módon e körülmények között egyetlen termék (2a, 2b, illetve 6a, 6b) képződött, jóllehet az irodalomban nem találtunk arra példát, hogy a két módszer közötti különbség befolyásolhatja a reakció szelektivitását. Mindkét eljárásban a nitril-oxid hasonló mechanizmus szerint képződik (7. ábra).

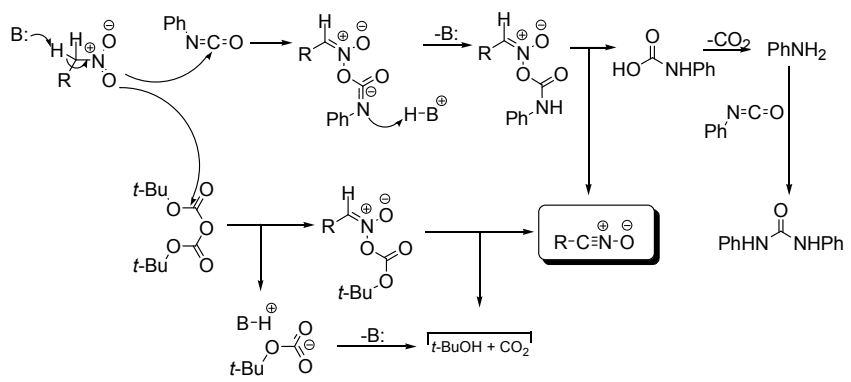

7. Ábra. Nitril-oxid generálása a Mukaiyama módszer alapján, primer nitroalkánból $\mathrm{Boc}_{2} \mathrm{O}$ vagy $\mathrm{PhNCO}$ vízelvonószer jelenlétében 
A reakció szelektívitásának alátámasztására DFT számításokat $^{10}$ végeztünk az 1 a vegyület és MeNCO reakciója között G03 program felhasználásával. Az átmeneti állapotok $\left(\Delta H^{*} ; \Delta G^{*}\right)$ és a termékek $(\Delta H ; \Delta G)$ reakció entalpia változásait valamint a Gibbs féle szabad energia változásait az 1 . táblázat tartalmazza. Kinetikus szempontból a cikloaddíciós reakció fötermékének a $\mathbf{4 a}$ vegyület javasolt, mivel ennek a legalacsonyabb a Gibbs féle szabad energiája $\left(\Delta G^{\ddagger}\right)$. Ezen szempont alapján a 3a vegyület kialakulása a legkedvezőtlenebb. Ezen kívül azt is megállapítottuk, hogy a 2a és 5a vegyületek gyakorlatilag azonos $\Delta G^{\ddagger}$ értékeket mutattak (1 Táblázat). A $4 \mathbf{a}$ komponens legalacsonyabb $\Delta G^{\ddagger}$ értékének magyarázatául szolgál az, hogy intermolekuláris H-kötés alakulhat ki a MeNCO és az etil-cisz-2-aminociklopent-3-énkarboxilát (1a) amid funkciója között (8. ábra). Hasonló eredményeket kaptunk HF/3-21G; B3LYP/6-31G(d,p) és B3LYP/6$311++\mathrm{G}(2 \mathrm{~d}, 2 \mathrm{p})$ számítások esetében is, függetlenül az alkalmazott oldószermodelltől [IEFPCM(THF)] és az elméleti modelltől, ezért kiterjesztettük komplexebb leírásra. Az irodalomban ismert, hogy néhány kiválasztott oldószer molekula vagy más komponens az oldószerben több információt adhat a mechanizmusról, ezért az általunk kiválasztott oldószer THF volt. Azonban a nitroalkán feleslege második oldószerként (koszolvens) szolgálhat, erős hidrogénkötést alakítva ki a kiindulási vegyület amid funkciójával. Ebben az esetben az eredmények megváltoztak. A legalacsonyabb $\Delta G^{\ddagger}$ értéket a $\mathbf{2 a}$ vegyület mutatta (8. ábra), valamint a 3a termék $\Delta G^{\ddagger}$ értéke nem sokban különbözött az előbbitől, ami alátámasztja a kísérleti eredményeket. A $\mathbf{4 a}$ és $\mathbf{5 a}$ cikloaddíciós termékeknél $\Delta G^{\ddagger}$ értékei minden esetben alacsonyabbak voltak, mint azok számított $\Delta G^{\ddagger}$ értékei vákuumban, mivel a nitro vegyület bizonyos mértékben elfoglalja a reaktív területet és megakadályozva ezáltal a MeNCO támadását (8. ábra).

1. Táblázat. A $\mathbf{2 b}, \mathbf{3 b}, \mathbf{4 b}$ és $\mathbf{5 b}$ cikloaddíciós termékek entalpia változásai $\left(\mathrm{kJ} \mathrm{mol}^{-1}\right)$ és Gibbs féle szabad energia változásai $\left(\mathrm{kJ}\right.$ mol$\left.{ }^{-1}\right)$ vákuumban, elméleti oldószer modell, illetve alkalmazott oldószermodell használatával

\begin{tabular}{|c|c|c|c|c|c|c|c|c|c|c|c|c|}
\hline & \multicolumn{4}{|c|}{ vákuumban } & \multicolumn{4}{|c|}{ oldószerben (THF) } & \multicolumn{4}{|c|}{ koszolvenssel } \\
\hline & $\overline{\Delta H^{*}}$ & $\Delta G^{\ddagger}$ & $\Delta H$ & $\Delta G$ & $\overline{\Delta H^{+}}$ & $\Delta G^{\ddagger}$ & $\Delta H$ & $\Delta G$ & $\Delta H^{\star}$ & $\Delta G^{\ddagger}$ & $\Delta H$ & $\Delta G$ \\
\hline $2 b$ & 55,8 & 114,1 & $-169,5$ & $-104,3$ & 59,1 & 118,2 & $-165,7$ & $-100,0$ & 67,3 & 126,1 & $-164,1$ & $-100,1$ \\
\hline $3 \mathbf{b}$ & 75,1 & 128,3 & $-159,1$ & $-97,2$ & 79,3 & 132,5 & $-154,1$ & $-92,0$ & 70,1 & 129,3 & $-153,4$ & $-92,0$ \\
\hline $4 b$ & 49,8 & 109,5 & $-164,1$ & $-101,5$ & 54,2 & 113,8 & $-160,3$ & $-98,1$ & 75,8 & 135,5 & $-160,2$ & $-97,7$ \\
\hline $5 \mathbf{b}$ & 54,9 & 113,7 & $-166,7$ & $-100,9$ & 58,2 & 117,9 & $-161,9$ & $-96,3$ & 95,4 & 153,9 & $-161,3$ & $-96,5$ \\
\hline
\end{tabular}
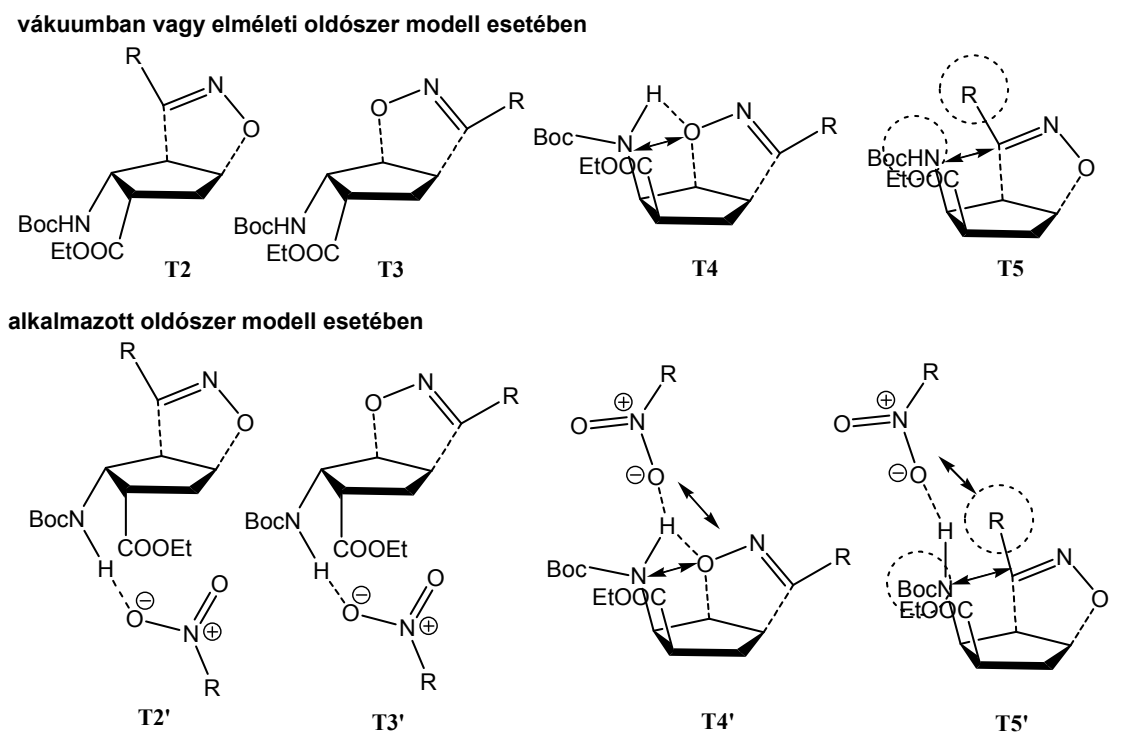

8. Ábra. A 2a, 3a, 4a és 5a cikloaddíciós termékek T2, T3, T4 és T5 átmeneti állapotai; sztérikus kölcsönhatások kialakulásai a -COOEt és a nitril-oxid között a T2 és T3 átmeneti állapotban, valamint-NHBoc és a nitril-oxid, valamint -COOEt és nitril-oxid közötti kölcsönhatás a T5 átmeneti állapotban és a H-kötéses kölcsönhatás kialakulása az-NHBoc és a nitril-oxid között a T4 átmeneti állapotban

További kísérleteinkben az etil-(transz-2-aminociklopent3-énkarboxilát)-ot használtuk dipolarofil-ként, melyet a megfelelő cisz aminoészter NaOEt-os epimerizációjával állítottunk elő. Nitril-oxid előállítására az 1. ábrán leírt módszert alkalmaztuk. Míg a cisz vegyület esetén a reakció nem volt teljesen szelektív, addig a transz származékkal végzett kísérlet során reakció teljes szelektivitással egy terméket (11) eredményezett, melyben az izoxazolin gyürü cisz térállású a karbamát, illetve amid funkcióhoz képest, és transz térállású az észter csoporthoz viszonyítva. A heterociklusban lévő oxigénatom pedig közelebb esik az amino funkcióhoz ( 9 . Ábra). Ezt az izomert korábban már sikerült elöállítanunk, mégpedig a minor (4) termék NaOEt-tal történő izomerizációjával. 


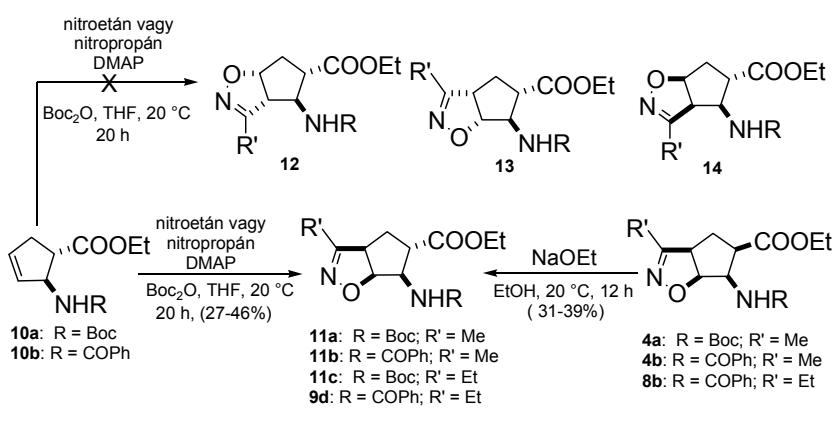

9. Ábra. Etil-transz-2-aminociklopent-3-énkarboxilátra végrehajtott 1,3dipoláros cikloaddíció

A reakciók szelektivitása feltehetően sztérikus és hidrogén-kötéses kölcsönhatással magyarázható. Az átmeneti állapotban sztérikus taszító hatás alakul ki a nitril-oxid és az észter csoport között, valamint hidrogénkötéses kölcsönhatás jön létre a karbamát hidrogénje, illetve a nitril-oxid között ${ }^{5 \mathrm{~d}}$ (10. ábra).

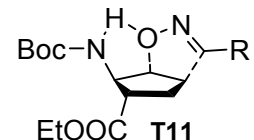

10. Ábra. T11 átmeneti állapot

A 2. és 3. ábrán bemutatott cikloaddíciós reakciók szelektivitása hasonlóképpen magyarázható. A két főtermék sztereokémiáját az észter funkció és a nitril-oxid között kialakult sztérikus taszítás határozza meg (10. ábra). A hidrogén-kötéses kölcsönhatás ez esetben elhanyagolható. A minor termékek esetében (5a, 5b és 9b) az átmeneti állapotban a H-kötéses kölcsönhatás a nitril-oxid és a karbamát funkció között erőteljesebb lehet, mint az észter és a nitril-oxid sztérikus taszító hatása. A lehetséges negyedik izomer azért nem képződhetett, mivel nem csak az észter és a nitril-oxid között alakulhat ki sztérikus taszítás, hanem a karbamát funkció és a nitriloxid alkil funkciója között is (11. ábra).

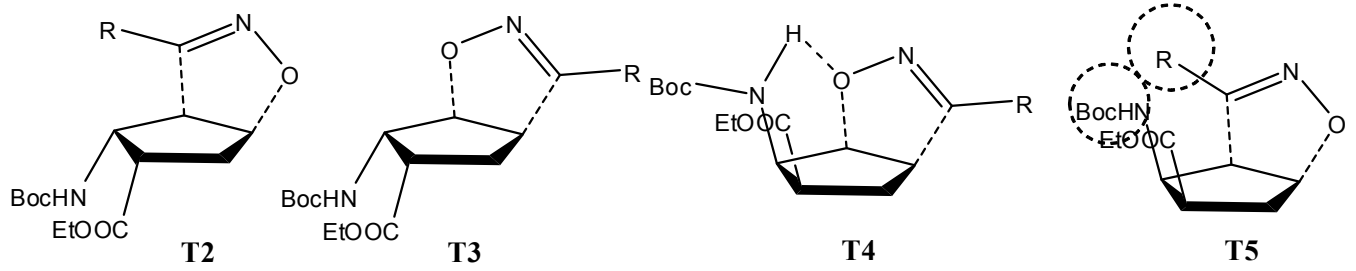

11. Ábra. A 2, 3, 4 és 5 cikloaddíciós termékekhez vezető reakciók átmeneti állapotai (T2, T3, T4, T5); sztérikus taszító kölcsönhatás az észter és a nitriloxid között a T2 és T3 állapotban, a karbamát és nitril-oxid között, valamint az észter és a nitril-oxid között a T5 átmeneti állapotban; és H-kötéses kölcsönhatás a karbamát és nitril-oxid között a T4 állapotban

A különböző szinteken elvégzett számításaink $[(B 3 L Y P / 6-31++G(d, p), \quad B 3 L Y P / 6-311++G(d, p) \quad$ és $\mathrm{B} 3 \mathrm{LYP} / 6-311++\mathrm{G}(2 \mathrm{~d}, 2 \mathrm{p})]$ az etil-transz-2-aminociklopent-3-énkarboxilát és a nitril-oxid között ugyanazon eredményeket mutatta, mint amiket a kísérletek során tapasztaltunk. A reakciók során a legkedvezőbb terméknek a 11a, 11b, 11c és 11d transzpentacin származék bizonyult (2. táblázat és 12 . ábra).

2. Táblázat. A 10a vegyületből keletkező transzpentacin származékok (11a, 12, 13 és 14) entalpia változásai $\left(\Delta \mathrm{H}^{\ddagger}\right)\left(\mathrm{kJ} \mathrm{mol}^{-1}\right)$, illetve Gibbs féle szabad energia változásai $\left(\Delta \mathrm{G}^{\ddagger}\right)\left(\mathrm{kJ} \mathrm{mol}^{-1}\right)$

\begin{tabular}{|c|c|c|c|c|}
\hline & \multicolumn{2}{|c|}{$10 \mathrm{a} \rightarrow \mathrm{TS}$} & \multicolumn{2}{|c|}{ 10a $\rightarrow$ termékek } \\
\hline & $\Delta \mathbf{H}^{\neq}$ & $\Delta \mathbf{G}^{\neq}$ & $\Delta H$ & $\Delta G$ \\
\hline $11 \mathrm{a}$ & 47,76 & 102,21 & $-170,02$ & $-106,24$ \\
\hline 12 & 65,32 & 119,90 & $-154,35$ & $-92,50$ \\
\hline 13 & 76,83 & 130,31 & $-152,22$ & $-90,46$ \\
\hline 14 & 55,36 & 113,99 & $-163,44$ & $-100,12$ \\
\hline
\end{tabular}

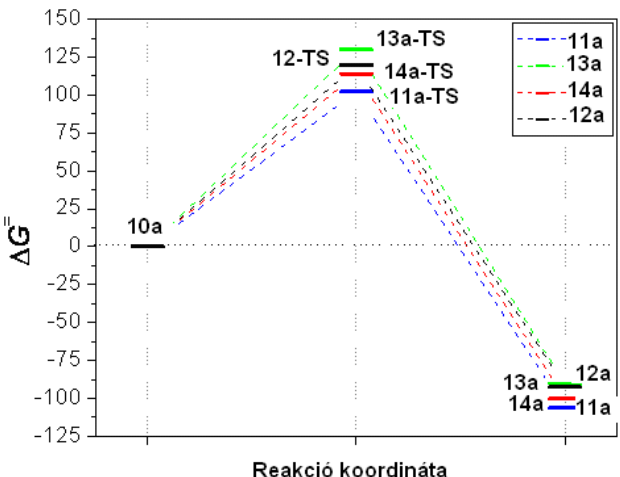

12. Ábra. A 10a vegyület átalakulásának energiadiagramja

Ezek alapján megállapítható, hogy nitril-oxid addíciójának szelektivitása az etil-transz-2-aminociklopent-3-énkarboxilátra nagymértékben hidrogén-kötéses kölcsönhatással magyarázható (13. ábra).
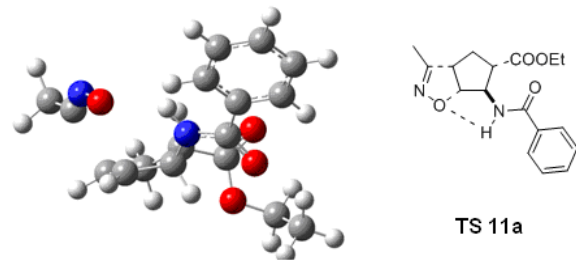

TS 11a 
13. Ábra. A 11a vegyülethez vezető reakció átmeneti állapotának Hkötéssel stabilizált szerkezete

Az előállított izoxazolinvázas $\beta$-aminoésztereket (2a, 2b; 3a, 3b; 6a, 6b; 7a, 7b) NaOEt-tal reagáltatva epimerizáció során a megfelelő transzpentacin származékokhoz jutottunk (12a, 12b, 12c, 12d, 13a, 13b, 13c, 13d) (14. ábra).

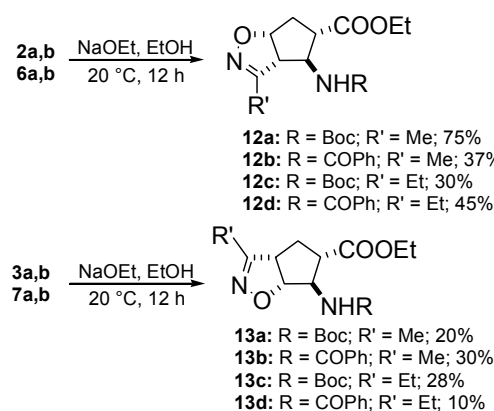

14. Ábra. Izoxazolingyürüvel kondenzált transzpentacin származékok szintézise a 2a, 2b; 6a, 6b; 3a, 3b és 7a, 7b vegyületek epimerizációjával

Érdemesnek tartottuk megvizsgálni a cikloaddíciós reakciót a szubsztrát változtatásával. A Boc-csoporttal kétszeresen védett cisz aminoészterrel (15) — mely esetében nem alakulhat ki hidrogénkötéses kölcsönhatás — is elvégeztük a reakciót (15. ábra).

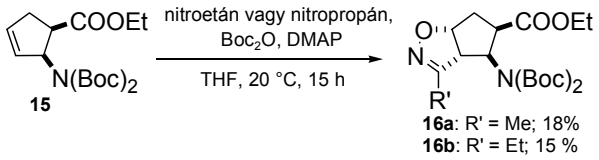

15. Ábra. Izoxazolin gyürüvel kondenzált ciszpentacin származékok szintézise kétszeresen Boc- védett cisz aminoészterből kiindulva

A reakcióban regio- és sztereoszelektíven egy termék (16a, 16b) képződött. A keletkezett termékben az izoxazolin gyürü transz térállású a karbamát és az észter csoporthoz viszonyítva (taszító sztérikus kölcsonhatás), valamint a gyürüben levő oxigénatom távolabb esik a karbamát csoporttól.

Ezután az izoxazolin gyürüvel kondenzált $\beta$-aminosavakat enantiomertiszta formában is elöállítottuk. Az enantiomertiszta kiindulási anyagot a racém $\beta$-laktám (17) enzimes rezolválásával állítottuk elő, az így keletkezett enantiomertiszta $\beta$-aminosavat $[(+)-18]$ a $(+)$-1 védett aminoészterré alakítottuk át. Nitril-oxid generálását nitroetánból, illetve 1-nitropropánból végeztük, PhNCO és DMAP jelenlétében (16. ábra). A keletkezett termékeket [(-)-2a, (-)-6a] NaOEt-tal izomerizáltuk, melynek során megkaptuk az enantiomertiszta transzpentacin származékokat $[(+)-12 a,(+)-12 c] \quad(16$. ábra).

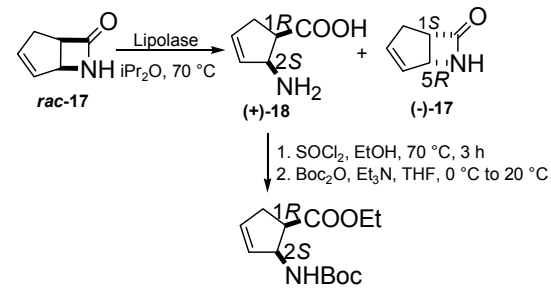

$(+)-1$

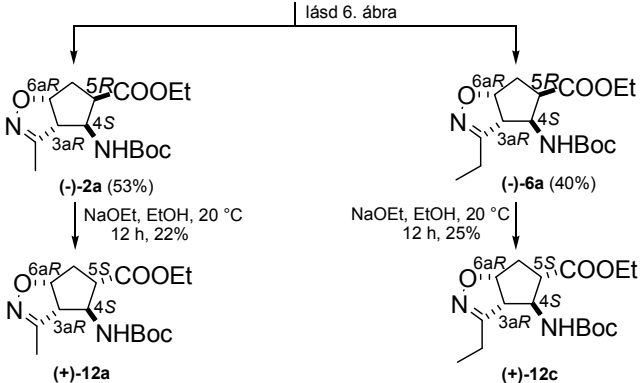

16. Ábra. Enantiomertiszta izoxazolingyürüvel kondenzált transzpentacin származékok szintézise etil cisz-2- aminociklopent-3énkarboxilátból

A cikloaddíciós reakciókat az enantiomertiszta etil transz2-aminociklopent-3-énkarboxilátra $\quad[(+)-\mathbf{1 0 a}] \quad$ is elvégeztük (17. ábra. $)^{10}$.

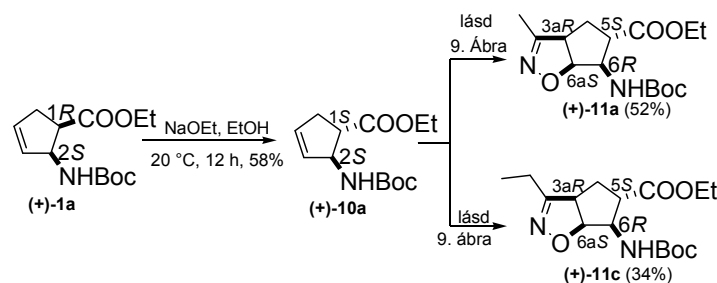

17. Ábra. Enantiomertiszta izoxazolingyürűvel kondenzált transzpentacin származékok szintézise etil-transz-2- aminociklopent-3énkarboxilátból

\section{3. Összefoglaló}

Kísérleti munkánk során új, izoxazolingyürüvel kondenzált ciszpentacin származékokat állítottunk elő. A nitril-oxid különböző módon történő generálásával, valamint a dipolarofil változtatásával teljes regio- és sztereoszelektivitást értünk el. A szelektivitást kémiai számításokkal is alátámasztottuk. Enantiomertiszta $\beta$ laktámból kiindulva az ixoxazolinvázas termékek enantiomerjeit is sikerült elöállítanunk.

\section{Köszönetnyilvánítás}

A szerzők köszönetet mondanak az OTKA (NK81371 K100530) támogatásáért.

\section{Hivatkozások}

1. (a.) Kai, H.; Matsumoto, H.; Hattori, N.; Takase, A.; Fujiwara, T.; Sugimoto, H. Bioorg. Med. Chem. Lett. 2001, 11, 1997-2000. (b.) Basappa, M.; Sadashiva, P.; Mantelingu, K.; Swamy, N. S.; Ranappa, K. S. Bioorg. Med. Chem. 2003, 11, 4539-4544. 
2. (a) Nair, V.; Suja, T. D. Tetrahedron 2007, 63, 12247 12275. (b) Gothelf, K. V.; Jorgensen, K. A. Chem. Rev. 1998, 98, 863-910. (c) Gallos, J. K.; Koumbis, A. E. Curr. Org. Chem. 2003, 7, 397-425. (d) Pellisier, H. Tetrahedron 2007, 63, 3235-3285. (e) Cycloaddition Reactions in Organic Synthesis; Kobayashi, S., Jorgensen, K. A., WileyVCH: Weiheim 2002. (f) Nitrile Oxides, Nitrones and Nitronates in Organic Synthesis; Torsell, K. B. G., New York, VCH, 1988. (g) Namboothiri, I. N. N.; Rastogi, N.; Ganguly, B.; Mobin, S. M.; Cojocaru, M. Tetrahedron 2004, 60, 1453-1462.

3. Mukaiyama, T.; Hoshino, T. J. Am. Chem. Soc. 1960, 62, 5339-5342.

4. Christl, M.; Huisgen, R. Chem. Ber. 1973, 106, 3345-3367.

5. (a) Pinto, A.; Conti, P.; De Amici, M.; Tamborini, L.; Grazioso, G.; Colleoni, S.; Mennini, T.; Gobbi, M.; De Micheli, C. Tetrahedron: Asymmetry 2008, 19, 867-875. (b) Conti, P.; Caligiuri, A.; Pinto, A.; Roda, G.; Tamborini, L.; Nielsen, B.; Madsen, U.; Frydenvang, K.; Colombo, A.; De Micheli, C. Eur. J. Med. Chem. 2007, 42, 1059-1068. (c) Roda, G.; Conti, P.; De Amici, M.; He, J.; Polavaropu, P. L.; De Micheli, C. Tetrahedron: Asymmetry 2004, 15, 30793090. (d) Conti, P.; De Amici, M.; Di Ventimiglia, S. J.; Stensbol, T. B.; Madsen, U.; Osborne, H. B.; Russo, E.; De Sarro, G.; Bruno, G.; De Micheli, C. J. Med. Chem. 2003, 46, 3102-3108.

6. (a) Chand, P.; Bantia, S.; Kotian, P. L.; El-Kattan, Y.; Lin, T-H.; Babu, Y. S. Bioorg. Med. Chem. 2005, 13, 4071-4077. (b) Chand, P.; Kotian, P. L.; Dehghani, A.; El-Kattan, Y.; Lin, T-H.; Hutchison, T. L.; Babu, Y. S.; Bantia, S.; Elliot, A. J.; Montgomery, J. A. J. Med. Chem. 2001, 44, 43794392. (c) Mineno, T.; Miller, M. J. J. Org. Chem. 2003, 68, 6591-6596.

7. (a) Fülöp, F. Chem. Rev. 2001, 101, 2181-2204. (b) Park, KH.; Kurth, M. J. Tetrahedron 2002, 58, 8629-8659. (c) Mittendorf, J.; Kunisch, F.; Matzke, M.; Militzer, H-C.; Schmidt, A.; Schönfeld, W. Bioorg. Med. Chem. Lett. 2003, 13, 433-436. (d) Hamersak, Z.; Roje, M.; Avdagic, A.;

\section{Synthesis of isoxazoline-fused cispentacin derivatives}

The 1,3-dipolar cycloaddition of nitrile oxides to alkenes has become widely used as a highly efficient method for the synthesis of izoxazolines. ${ }^{2}$ A number of nitrile oxide cycloadditions to cyclic $\alpha$ - or $\gamma$-amino acid derivatives have been performed in recent years with the aim of the synthesis of different biologically active compounds. Alicyclic $\beta$-amino acids have acquired great interest in recent years because of their pharmacological potential.

Our aim was to synthetize novel, isoxazoline-fused $\beta$ aminocyclopentanecarboxylates regio- and stereoisomers in racemic and enantiomerically pure form.

When amino ester 1a (with Boc amino protecting group) was submitted to the cycloaddition reactions in THF at $20{ }^{\circ} \mathrm{C}$ for 15 $\mathrm{h}$ two regioisomers and a diastereomer $\mathbf{2 a}, \mathbf{2 b}, \mathbf{3 a}, \mathbf{3 b}, \mathbf{4 a}, \mathbf{4 b}$ were detected and isolated in moderate yields (Scheme 1, Scheme 3). The regioselectivity can probably be explained in terms of electronic factors: because of the electron-withdrawing effect of the nitrogen atom of the carbamate, the negatively charged oxygen atom of the dipolar agent attacks at C-4 of amino ester $\mathbf{1 a}, \mathbf{1 b}$, farthest from the carbamate or amide group.

The synthetic routes have also been applied for the synthesis of enantiomerically pure isoxazoline-fused $\beta$-aminocyclopentane carboxylates (Scheme 5).
Sunjic, V. Tetrahedron: Asymmetry 2007, 18, 635-644. (e) Yang, D.; Zhang, D-W.; Hao, Y.; Wu, Y-D.; Luo, S-W.; Zhu, N-Y. Angew. Chem. Int. Ed. 2004, 43, 6719-6722. (f) Rathore, N.; Gellman, S. H.; Pablo, J. J. Biophys. J. 2006, 91, 3425-3435. (g) Kiss. L.; Fülöp, F. Synlett 2010, 1302.

8. (a) Porter, E. A.; Weisblum, B.; Gellman, S. H. J. Am. Chem. Soc. 2005, 127, 11516-11529. (b) Roy, O.; Faure, S.; Aitken, D. J. Tetrahedron Lett. 2006, 47, 5981-5984. (c) Chandrasekhar, S.; Sudhakar, A.; Kiran, M. U.; Babu, B. N.; Jagadeesh, B. Tetrahedron Lett. 2008, 49, 7368-7371. (d) Rua, F.; Boussert, S.; Parella, T.; Diez-Perez, I.; Branchadell, V.; Giralt, E.; Ortuno, R. M. Org. Lett. 2007, 9, 3643-3645. (e) D'Elia, V.; Zwicknagl, H.; Reiser, O. J. Org. Chem. 2008, 73, 3262-3265. (f) Hetényi, A.; Szakonyi, Zs.; Mándity, I. M.; Szolnoki, É.; Tóth, G. K.; Martinek, T. A:; Fülöp, F. Chem. Commun. 2009, 177-179. (g) Fülöp, F.; Martinek, T. A.; Tóth, G. K. Chem. Soc. Rev. 2006, 35, 323 334. (h) Martinek, T. A.; Tóth, G. K.; Vass, E.; Hollósi, M.; Fülöp, F. Angew. Chem. Int. Ed. 2002, 41, 1718-1721. (i) Hetényi, A.; Mándity, I. M.; Martinek, T. A.; Tóth, G. K.; Fülöp, F. J. Am. Chem. Soc. 2005, 127, 547-553. (j)

Martinek, T. A.; Fülöp, F. Eur. J. Biochem. 2003, 270, 3657-3666. (k) Torres, E.; Acosta-Silva, C.; Rua, F.; Alvarez-Larena, A.; Parella, T.; Branchadell, V.; Ortuno, R. M. Tetrahedron 2009, 65, 5669-5675. (1) Fernandez, D.;

Torres, E.; Aviles, F. X.; Ortuno, R. M.; Vendrell, J. Bioorg. Med. Chem. 2009, 17, 3824-3828. (m) Fernandes, C.;

Pereira, E.; Faure, S.; Aitken, D. J. J. Org. Chem. 2009, 74, 3217-3220. (n) Kiss, L.; Forró, E.; Fülöp, F. Synthesis of carbocyclic $\beta$-amino acids. Amino Acids, Peptides and Proteins in Organic Chemistry. Vol. 1, Ed. A. B. Hughes, Wiley, Weinheim, 2009, 367-409.

9. Kiss, L.; Nonn, M.; Forró, E.; Sillanpää, R.; Fülöp, F. Tetrahedron Lett. 2009, 50, 2605-2608.

10. Nonn, M.; Kiss, L.; Forró, E.; Mucsi, Z.; Fülöp, F.; Tetrahedron 2011, 67, 4079-4085.

Since the above procedure was not selective, we continued our experiments to search for other synthetic routes for the preparation of isoxazoline-fused cispentacins with higher selectivity. 1a, 1b were subjected to 1,3-dipolar cycloaddition under the conditions, using $\mathrm{RNO}_{2}, \mathrm{PhNCO}_{2} \mathrm{Et}_{3} \mathrm{~N}$ in THF at 65 ${ }^{\circ} \mathrm{C}$ (Scheme 6). The reactions resulted $100 \%$ selectively in $\mathbf{2 a}$, $\mathbf{2 b}, \mathbf{2 c}, \mathbf{2 d}$. The explanation of the unexpected selectivity under these reaction conditions is not yet clear. The mechanism of the generation of nitrile oxide with $\mathrm{PhNCO}$ and $\mathrm{Et}_{3} \mathrm{~N}$ is similar to that for $\mathrm{Boc}_{2} \mathrm{O}$ and DMAP (see Scheme 7). We are not aware of any similar example in the literature.

Whereas the addition to the corresponding cis isomer (1a, 1b) gave three isomers (Scheme 1 and 3 ), under the same experimental conditions $\left(\mathrm{RNO}_{2}, \mathrm{Boc}_{2} \mathrm{O}\right.$ and DMAP) the trans

counterparts (10a, 10b) furnished selectively only one cycloadduct isomer (11a, 11b, 11c, 11d) (Scheme 9), which can be synthetized by epimerization of very minor product $(\mathbf{4 a}, \mathbf{4 b}$, 4c, 4d) in the presence of $\mathrm{NaOEt}$ in $\mathrm{EtOH}$. The selectivity is probably explained by steric and H-bonding interactions (Scheme 10).

The synthetized isoxazoline-fused cispentacin derivatives (Scheme 1 and 3) offered an opportunity for the preparation of new isoxazoline-fused transpentacin derivatives. Accordingly, 2a, 2b, 3a, 3b, 6a, 6b, 7a, 7b were epimerized at C-5 with $\mathrm{NaOEt}$ in EtOH to give izoxazoline-fused amino esters (Scheme 14), in which the amino and carboxylate functions were trans. 
Next, the diprotected cis amino ester $\mathbf{1 7}$ was reacted with nitrile oxides under the conditions given in Scheme 1 and 3 and the transformation led to only the trans isoxazoline-fused derivatives (18a and 18b) (Scheme 15). This selectivity can be explained with electron-withdrawing effect of the nitrogen atom of the carbamate, H-bonding interactions were not possible between the diprotected amino function and the nitrile oxide.

The regio- and stereoselectivity of the nitrile oxide 1,3-dipolar cycloadditon were confirmed by theoretical calculations too (see Table 1, 2 and Scheme 12).

The $100 \%$ regio- and stereoselective synthesis of $\mathbf{2 a}$ and $\mathbf{6 a}$ (Scheme 6) and 11a and 11c (Scheme 9) was extended to their preparation in enatiomerically pure form starting from tha racemic $\beta$-lactam (rac-17)(Scheme 16).

In conclusion, isoxazoline-fused cispentacin derivatives were synthetized regio- and stereoselectively via the 1,3-dipolar cycloaddition of nitrile oxides to cis- and trans-ethyl 2-amino-3cyclopentenecarboxylates. The cycloadducts were also prepared in enantiomerically pure form. 
V. 


\title{
Selective nitrile oxide dipolar cycloaddition for the synthesis of highly functionalized $\beta$-aminocyclohexanecarboxylate stereoisomers
}

\author{
Melinda Nonn, ${ }^{\text {a,b }}$ Loránd Kiss, ${ }^{a}$ Reijo Sillanpää ${ }^{c}$ Ferenc Fülöp ${ }^{\text {a,b* }}$ \\ ${ }^{a}$ Institute of Pharmaceutical Chemistry, ${ }^{b}$ Stereochemistry Research Group of the Hungarian \\ Academy of Sciences, University of Szeged, H-6720 Szeged, Eötvös u. 6, Hungary \\ ${ }^{c}$ Department of Chemistry, University of Jyväskylä, FIN-40351, Jyväskylä, Finland
}

\begin{abstract}
Highly functionalized $\beta$-aminocyclohexanecarboxylate regio- and stereoisomers were synthesized from a bicyclic $\beta$-lactam by successive regioselective iodolactonization, stereo- and regioselective nitrile oxide cycloaddition, lactone ring opening and isoxazoline ring opening.
\end{abstract}

\section{Introduction}

As important bioactive derivatives, highly functionalized cyclic amino acids have been at the focus of organic and medicinal chemistry interest during the past ten years. Multifunctionalized cyclohexane amino acids such as the antibiotic Oryzoxymycin ${ }^{1}$ and the antiviral agents Tamiflu, ${ }^{2}$ Zanamivir and 2,3-didehydro-2-deoxy- $N$-acetylneuraminic acid $(\text { DANA })^{3}$ (Figure 1) are important derivatives with high pharmacological potential. Their modified derivatives ${ }^{4}$ and other functionalized derivatives ${ }^{5}$ exhibit strong antiviral, antifungal or antibacterial activities. 
<smiles>C[C@H](OC(=O)C1=CC=C[C@H](O)C1N)C(=O)O</smiles>

Oryzoxymycin<smiles>CCOC(=O)C1=C[C@H](OC(CC)CC)[C@H](NC(C)=O)[C@@H](N)C1</smiles>

Tamiflu (Oseltamivir)<smiles>N=C(N)N[C@H]1C=C(C(=O)O)O[C@H](C(O)[C@H](O)CO)[C@H]1N</smiles>

Zanamivir<smiles>CCC(CC)C(N)C1C(O)C(C(=O)O)C[C@H]1NC(=N)N</smiles>

Peramivir<smiles>NC1C(O)C=C(C(=O)O)OC1(O)C(O)CO</smiles>

DANA

Figure 1. Several bioactive highly functionalized cyclic amino acids

The dipolar cycloaddition of nitrile oxides to unsaturated cyclic amino acid derivatives has been efficiently applied for the preparation of substituted cyclic amino acids or amino alcohols ${ }^{6}$ and for the selective synthesis of highly functionalized bioactive cyclopentane amino acid derivatives, e.g. Peramivir ${ }^{7}$ (Figure 1) and its analogues. ${ }^{8}$ Among the large family of $\beta$-amino acids with high pharmacological potential, ${ }^{1 c, 9}$ the highly substituted derivatives are an interesting class of compounds which have received considerable attention in recent years. Isoxazoline-fused cispentacin stereo- and regioisomers were recently prepared via a nitrile oxide cycloaddition. ${ }^{10}$ Our current aim was the synthesis of highly functionalized 2aminocyclohexanecarboxylate stereoisomers from bicyclic $\beta$-lactam 1 through nitrile oxide cycloaddition.

\section{Results and Discussion}

The synthetic procedure consisted of a modified regio- and stereoselective iodolactonization and dehydroiodination, lactone opening, regio- and stereoselective nitrile oxide cycloaddition 
to the hydroxylated cyclohexene amino esters formed and finally the reductive opening of the isoxazoline ring.

Amino acid $\mathbf{2}$ derived from lactam 1 was subjected to a slightly modified procedure in comparison with earlier presented method; ${ }^{11}$ iodolactonization procedure by treatment at room temperature with 1.5 equiv of $\mathrm{NaHCO}_{3}$ and 1.5 equiv of $\mathrm{KI}$, followed by the addition of 1.5 equiv of $\mathrm{I}_{2}$ in portions during 20 min with stirring for $24 \mathrm{~h}$, which gave iodolactone 3 in high yield (Scheme 1). Modified dehydroiodination with the addition of 2.1 equiv of DBU as base and stirring at $40{ }^{\circ} \mathrm{C}$ for $8 \mathrm{~h}$ resulted in unsaturated lactone $4(91 \%)$. Lactone ring opening with NaOEt under different reaction conditions furnished hydroxylated amino ester stereoisomers: $5(74 \%)$ at $-10{ }^{\circ} \mathrm{C}$ to $0{ }^{\circ} \mathrm{C}$ for $1 \mathrm{~h}$ and its epimer $6(76 \%)$ at $0{ }^{\circ} \mathrm{C}$ to $20{ }^{\circ} \mathrm{C}$ for $20 \mathrm{~h}\left(\right.$ Scheme 1). ${ }^{11}$

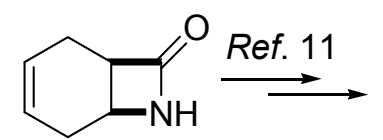

1

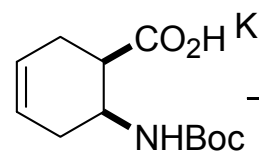

2
$\mathrm{II}$ (1.5 equiv), $\mathrm{I}_{2}$ ( 1.5 equiv)

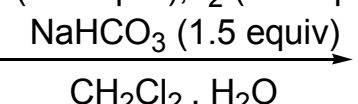
$20^{\circ} \mathrm{C}, 24 \mathrm{~h}, 89 \%$

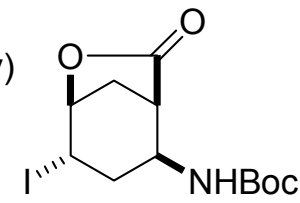

3

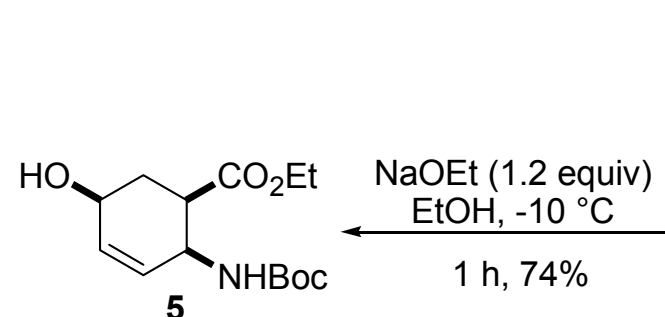

5

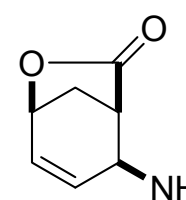

4

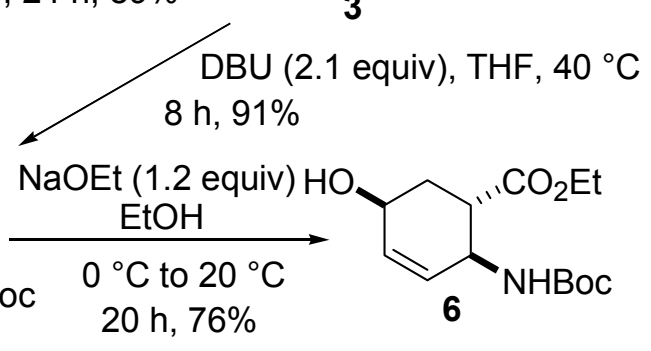

Scheme 1. Synthesis of bicyclic lactone $\mathbf{4}$ and hydroxylated $\beta$-amino carboxylates $\mathbf{5}$ and $\mathbf{6}$

Hydroxylated aminocarboxylates $\mathbf{5}$ and $\mathbf{6}$ were subjected to the attempted 1,3-dipolar cycloaddition with acetonitrile N-oxide (generated from nitroethane, di-tertbutoxycarbonylanhydride $\left(\mathrm{Boc}_{2} \mathrm{O}\right)$ and dimethylaminopyridine (DMAP) in THF). Although the reaction was tried under different conditions, such as the Huisgen (from aldoximes) ${ }^{12}$ and Mukayama (from primary nitroalkanes) ${ }^{13}$ methodologies in different solvents, the required 
cycloadduct could not be prepared. The reason is probably the low reactivity due to the sterical and electronical reasons of the isolated ring double bond in $\mathbf{5}$ and $\mathbf{6}$ (Scheme 2).

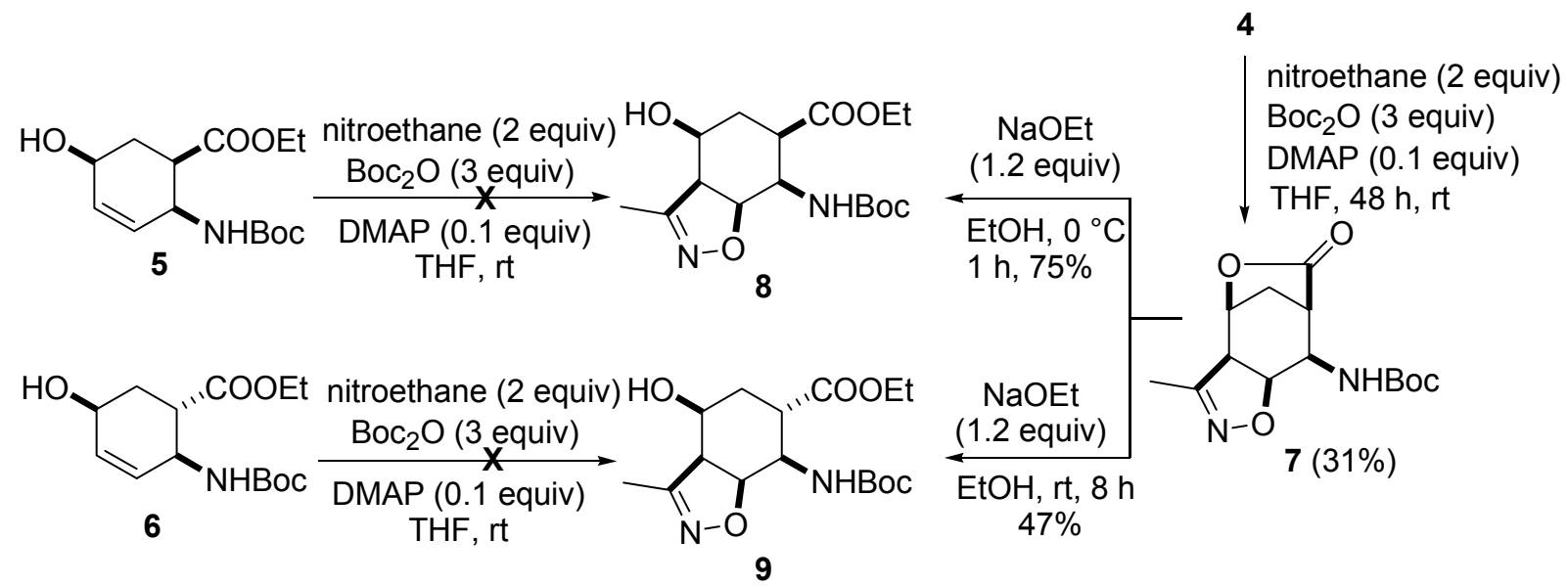

Scheme 2. Unsuccessful and successful routes for the synthesis of isoxazoline-fused $\beta$-amino carboxylates 8 and 9

However, unsaturated cis-lactone 4 (Figure 1), ${ }^{11}$ derived from azetidinone 1, underwent the cycloaddition of the acetonitrile $\mathrm{N}$-oxide to furnish the isoxazoline-fused aminolactone 7 regio- and stereoselectively as the sole cycloaddition product, in which the isoxazoline ring and the carbamate group have cis relative stereochemistry, while the oxygen atom of the isoxazoline ring is closest to the carbamate (Scheme 2).

Face of attack of the nitrile oxide on the $\mathrm{C}=\mathrm{C}$ bond of lactone 4 can be explained by a hydrogen-bonding directing effect, ${ }^{10 \mathrm{~b}, 14}$ from the carbamate, leading to the all-cis derivative 7 . 


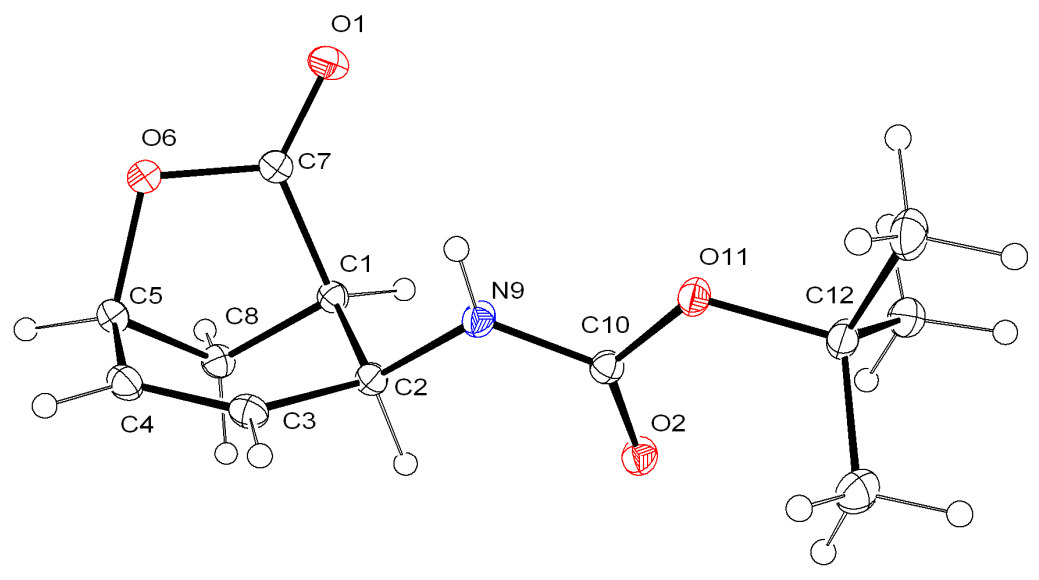

Figure 2. Ortep structure of 4

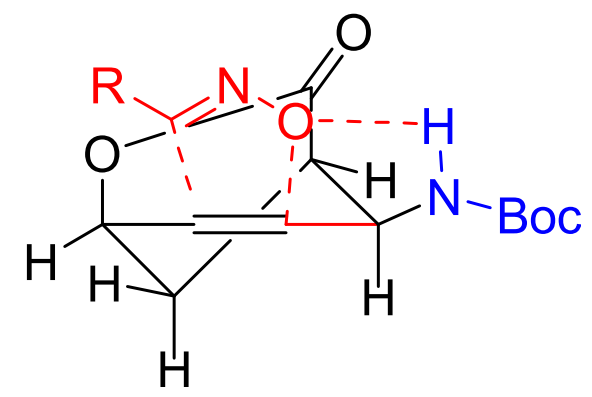

Figure 3. H-bonding interaction between nitrile oxide and carbamate

Next, 7 was subjected to lactone ring opening with NaOEt. When performed at $0{ }^{\circ} \mathrm{C}$ for $1 \mathrm{~h}$, the reaction afforded hydroxylated isoxazoline-fused aminocyclohexanecarboxylate $\mathbf{8}$ in $75 \%$ yield. In contrast, at $20^{\circ} \mathrm{C}$ for $8 \mathrm{~h}$, epimerization occurred at C-8 to give hydroxylated amino ester 9, a diastereoisomer of $\mathbf{8}$, in $47 \%$ yield (Scheme 2). The rather modest yield was probably a result of the formation of various polymeric materials in the latter reaction. 


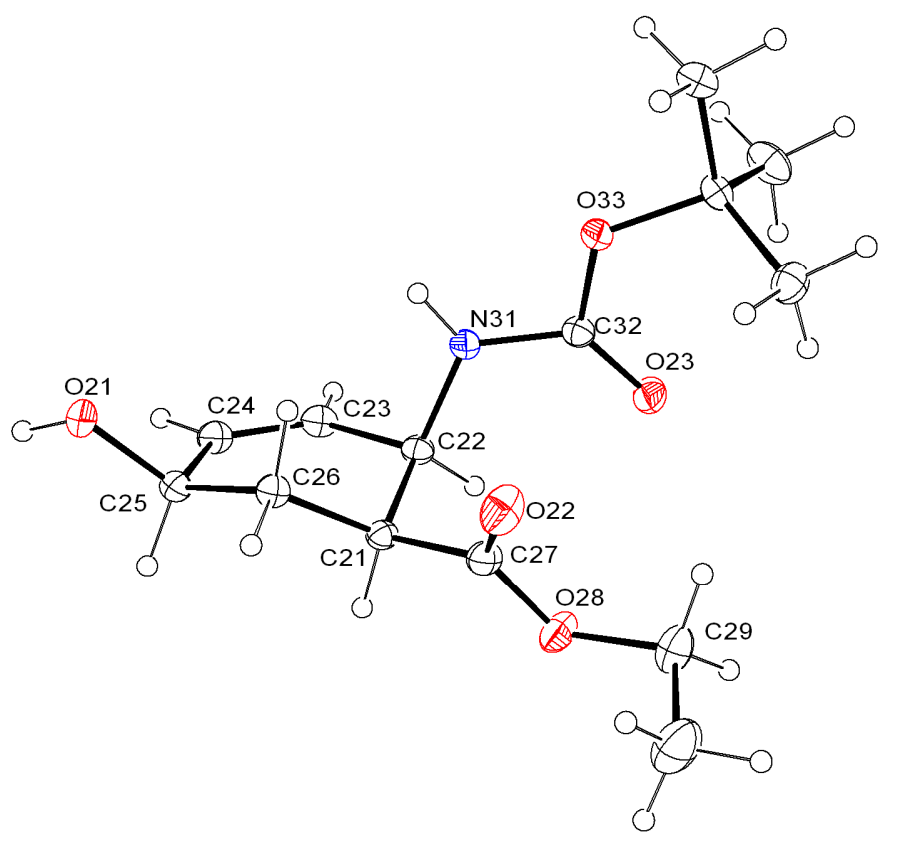

Figure 4. Ortep structure of 5

The reason why isoxazolines $\mathbf{8}$ and $\mathbf{9}$ could not be prepared by the addition of nitrile oxide to the C-C double bond of hydroxylated amino ester 5 (Figure 4) or 6 (Figure 5) is unclear. We initially assumed that it might be due to a difference length of the $\mathrm{C}-\mathrm{C}$ double bond in the structures of 4 (Figure 1) and $\mathbf{5}$ and $\mathbf{6}$. We supposed that the rigidity in the structure of lactone 4 would lead to a longer $(\mathrm{C} 3-\mathrm{C} 4 \mathrm{C}=\mathrm{C})$ bond distance than that in $\mathbf{5}(\mathrm{C} 23-\mathrm{C} 24$ in ORTEP, Figure 4) or 6. Unfortunately, X-ray studies did not support this assumption. The C-C double bond distance in $\mathbf{4}$ was $1.3230 \AA$, while that in $\mathbf{5}$ was $1.325 \AA$, i.e. no relevant difference. Thus, the difference in reactivity of the $\mathrm{C}-\mathrm{C}$ double bond in these two types of molecules appears to be attributable to stereochemical reasons: our experimental results indicated that the rigid ring framework in $\mathbf{4}$ results in a much higher reactivity of the $\mathrm{C}-\mathrm{C}$ olefinic bond than in $\mathbf{5}$ or $\mathbf{6}$, without such a constrained system. 


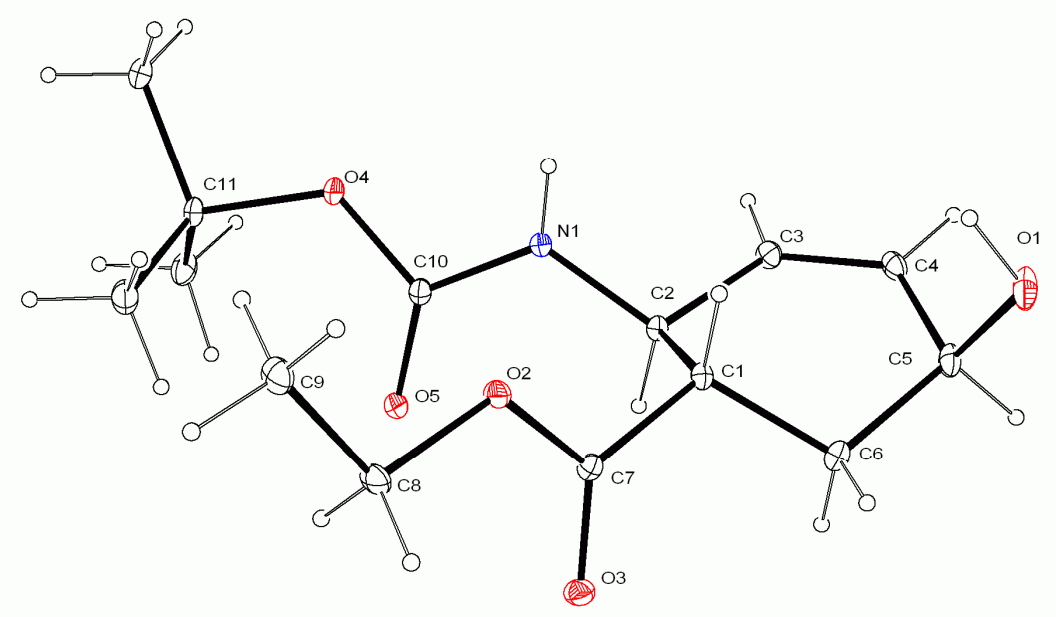

Figure 5. Ortep structure of 6

Next, in order to synthesize the desired multisubstituted $\beta$-amino esters, the isoxazoline-fused esters 8 and 9 were submitted to reductive ring-opening. Catalytic hydrogenation over $\mathrm{Pd} / \mathrm{C}$ in $\mathrm{MeOH}$ with drops of $\mathrm{HCl}$ at 10 bar led to the desired ring-opened products (10 and 11) in rather low isolated yields. With $\mathrm{NaBH}_{4}$ in the presence of $\mathrm{NiCl}_{2}$, the stereochemistry of the new stereocentre could not be determined, but it most probably corresponded with the earlier experiments where the $\mathrm{H}$ attack occurred from the same side as the carbamate, (with the formation of a new stereocentre at $1 \mathrm{C}$ distance from $\mathrm{C}-4)\left(\right.$ Scheme 3). ${ }^{7,15}$ 

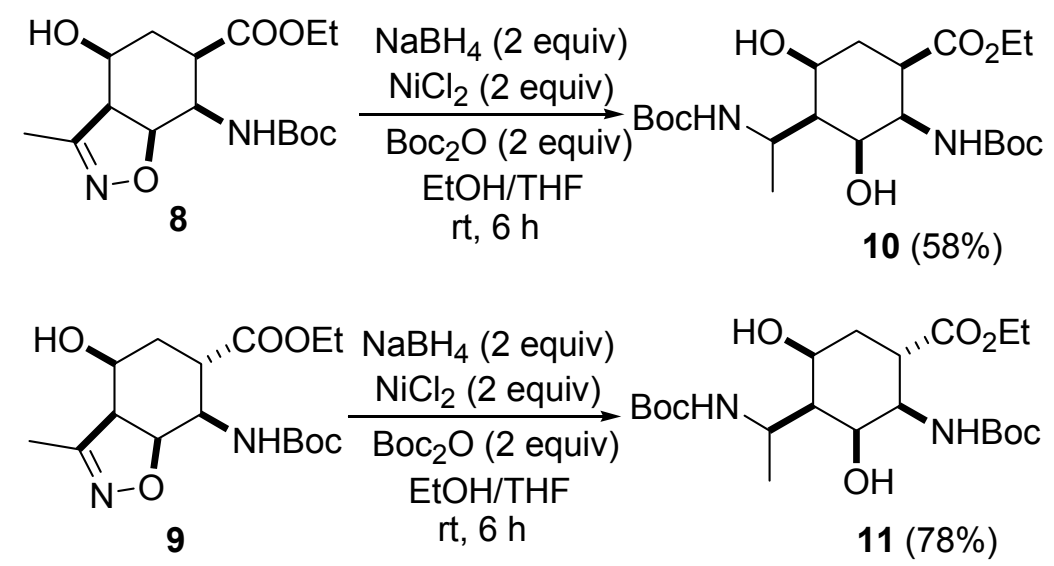

Scheme 3. Synthesis of highly functionalized $\beta$-amino carboxylates 10 and 11

The successful synthetic procedures presented above were next attempted for the synthesis of other novel highly substituted $\beta$-aminocyclohexanecarboxylates. Hydroxylated cyclohexene amino ester 14, a stereoisomer of 5 and $\mathbf{6}$, was synthesized from 1 via trans-lactone $13^{11}$ by applying the modified iodolactonization and dehydroiodination presented in Scheme 1 . Cycloaddition to hydroxylated ester $\mathbf{1 4}$ again failed, leading to no isoxazoline-fused products. However, the addition of the nitrile oxide derived from nitroethane to lactone $\mathbf{1 3}$ (Scheme 4) resulted regio- and stereoselectively in isoxazoline 15, in which (as a result of the H-bonding) the isoxazoline ring is cis to the carbamate, while the oxygen atom of the heterocycle is closest to this group (NHBoc). ${ }^{10 b, 14}$

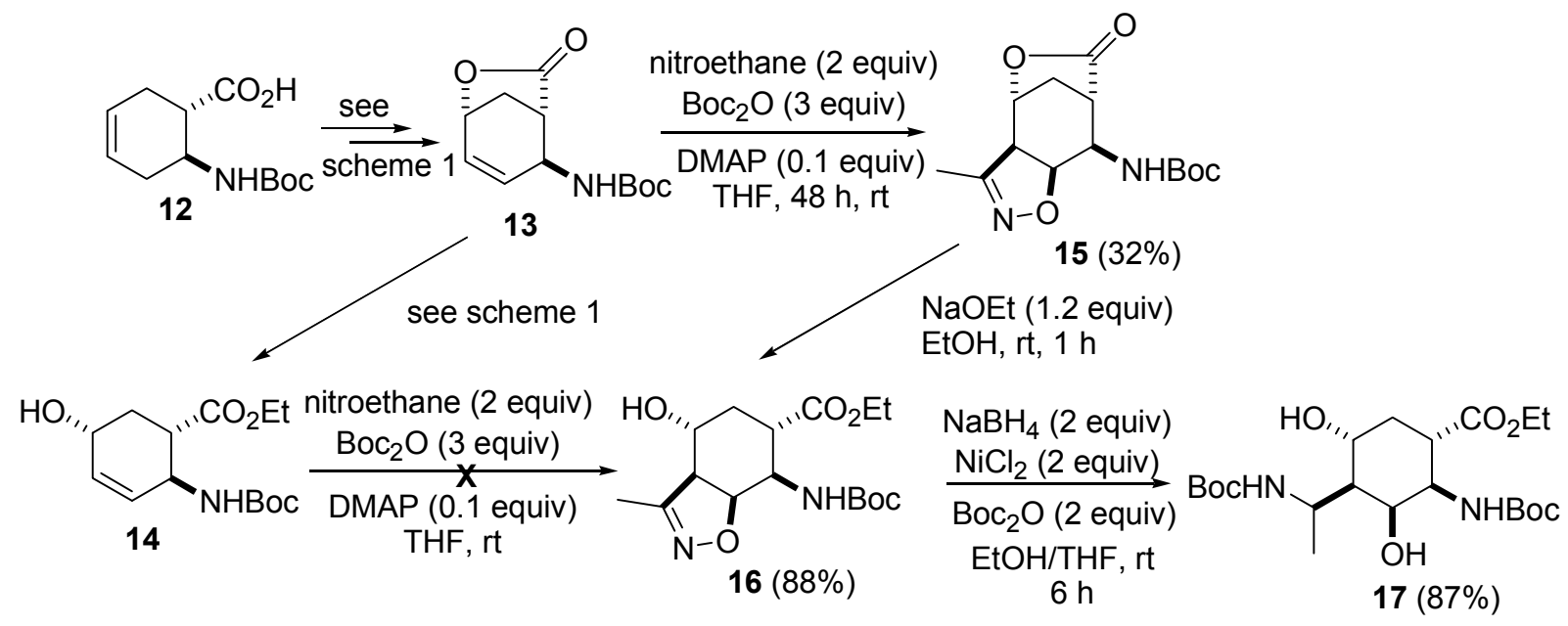


Scheme 4. Synthesis of highly functionalized $\beta$-amino carboxylate 17

On the treatment of $\mathbf{1 5}$ with $\mathrm{NaOEt}$, lactone ring-opening resulted in the corresponding hydroxylated ester 16, isoxazoline ring-opening with $\mathrm{NaBH}_{4} / \mathrm{NiCl}_{2}$ gave the corresponding highly functionalized amino ester 17 (Scheme 4).

In conclusion, three highly functionalized cyclohexane $\beta$-amino ester stereoisomers were prepared by regio- and stereoselective cycloaddition of nitrile oxides to unsaturated bicyclic amino lactones, followed by reductive opening of the isoxazoline ring. These multifunctionalized cyclic aminocarboxylates with multiple stereocenters may be regarded as promising $\beta$-amino acid analogues of bioactive compounds e.g. Tamiflu and Zanamivir.

\section{Experimental}

The chemicals were purchased from Aldrich. Melting points were determined with a Kofler apparatus. NMR spectra were recorded on Bruker DRX 400 and $500 \mathrm{MHz}$ spectrometers. Chemical shifts are given in ppm relative to TMS as internal standard, with $\mathrm{CDCl}_{3}$ or DMSO as solvent. The solvents were used as received from the supplier. Mass spectra were recorded on a Finnigan MAT 95S spectrometer. Elemental analyses were performed with a PerkinElmer CHNS-2400 Ser II Elemental Analyzer.

\section{General procedure for iodolactonization}

To a solution of $N$-Boc-protected amino acid (36 mmole, 2) in $\mathrm{CH}_{2} \mathrm{Cl}_{2}(150 \mathrm{~mL}), \mathrm{H}_{2} \mathrm{O}(200$ $\mathrm{mL}$ ) was added, followed by $\mathrm{NaHCO}_{3}$ (1.5 equiv) and $\mathrm{KI}$ (1.5 equiv). To this mixture, $\mathrm{I}_{2}(1.5$ equiv) was added in portions during $20 \mathrm{~min}$. After stirring for $24 \mathrm{~h}$ at room temperature, the mixture was taken up in $\mathrm{CH}_{2} \mathrm{Cl}_{2}(300 \mathrm{~mL})$, and washed with saturated aqueous $\mathrm{Na}_{2} \mathrm{SO}_{3}$ solution. The organic layer was then dried $\left(\mathrm{Na}_{2} \mathrm{SO}_{4}\right)$ and concentrated under reduced pressure, giving $3^{11}$ 


\section{General procedure for dehydroiodination}

To a solution of iodolactone (12 mmole, 3) in THF (60 mL), DBU (2.1 equiv) was added and the mixture was stirred at $40{ }^{\circ} \mathrm{C}$ for $8 \mathrm{~h}$. The solution was then concentrated under reduced pressure and the residue was taken up in EtOAc $(140 \mathrm{~mL})$. The organic layer was washed with $\mathrm{H}_{2} \mathrm{O}(3 \times 70 \mathrm{~mL})$, dried $\left(\mathrm{Na}_{2} \mathrm{SO}_{4}\right)$ and concentrated under vacuum. The residue was crystallized from $n$-hexane-EtOAc, giving 4 (a similar procedure for 13). ${ }^{11}$

\section{General procedure for lactone ring-opening reactions}

To a solution of lactone 4 (10.5 mmole) in EtOH (15 mL), NaOEt (12.6 mmole) was added and the mixture was stirred at $-10{ }^{\circ} \mathrm{C}$ for $1 \mathrm{~h}$. The mixture was concentrated under reduced pressure, and the residue was then diluted with $\mathrm{CHCl}_{3}(50 \mathrm{~mL})$, washed with $\mathrm{H}_{2} \mathrm{O}(3 \mathrm{X} 20$ $\mathrm{mL})$, dried $\left(\mathrm{Na}_{2} \mathrm{SO}_{4}\right)$ and concentrated under reduced pressure. The product 5 was purified by crystallization ( $n$-hexane-EtOAc). When the reaction was carried out at r.t. under the same reaction conditions the epimerized diastereomer $\mathbf{6}$ was obtained.

\section{General procedure for synthesis of isoxazoline-fused lactones}

To a solution of lactone (4 or 15) (12.55 mmole) in THF (20 mL), $\mathrm{EtNO}_{2}(25.1 \mathrm{mmole})$, $\mathrm{Boc}_{2} \mathrm{O}(37.6 \mathrm{mmole})$ and DMAP $(1.3 \mathrm{mmol})$ were added and the mixture was stirred at $22{ }^{\circ} \mathrm{C}$ for $48 \mathrm{~h}$. The reaction mixture was then diluted with EtOAc $(75 \mathrm{~mL})$ and extracted with $\mathrm{H}_{2} \mathrm{O}$ ( $3 \times 20 \mathrm{~mL})$, dried $\left(\mathrm{Na}_{2} \mathrm{SO}_{4}\right)$ and concentrated under reduced pressure. The crude residue was purified by column chromatography on silica gel ( $n$-hexane-EtOAc), giving 7 and 15.

\section{Tert-butyl-(1 $\left.S^{*}, 2 S^{*}, 6 S^{*}, 7 R^{*}, 8 R^{*}\right)-(3-$ methyl-9-oxo-5,10-dioxa-4-azatricyclo-}

\section{$\left[6.2 .1 .0^{2,6}\right]$ undec-3-en-7-yl)-carbamoate (7)}

A yellowish-white solid; yield 31\% (1.15 g); Mp: $160-161{ }^{\circ} \mathrm{C} ; \mathrm{R}_{\mathrm{f}}=0.32$ (n-hexane-EtOAc 1:2); ${ }^{1} \mathrm{H}$ NMR (500 MHz, DMSO): $\delta=1.39$ (s, 9H, $\mathrm{CH}_{3}$ ), 1.69 (d, $\left.1 \mathrm{H}, \mathrm{H}-8, J=12.0 \mathrm{~Hz}\right), 1.92$ (s, 3H, $\left.\mathrm{CH}_{3}\right), 2.38-2.45\left(\mathrm{~m}, 1 \mathrm{H}, \mathrm{CH}_{2}\right), 2.59-2.64\left(\mathrm{~m}, 1 \mathrm{H}, \mathrm{CH}_{2}\right), 3.49-3.56(\mathrm{~m}, 1 \mathrm{H}, \mathrm{H}-7), 3.86$ (d, 1H, H-2, $J=10.0 \mathrm{~Hz}), 4.66-4.73$ (m, 1H, H-6), 5.02-5.07 (m, 1H, H-1), 7.38 (d, 1H, N-H, 
$J=7.4 \mathrm{~Hz}) .{ }^{13} \mathrm{C}$ NMR (100 MHz, DMSO): $\delta=11.0,28.2,31.2,40.8,53.9,54.9,59.8,75.3$, 78.4, 79.3, 155.3, 174.8. Anal. Calcd. For $\mathrm{C}_{14} \mathrm{H}_{20} \mathrm{~N}_{2} \mathrm{O}_{5}$ : C, 56.75; H, 6.80; N, 9.45. Found: C, 56.50; H, 6.99; N, 9.11.

Tert-butyl-(3-methyl-9-oxo-5,10-dioxa-4-azatricyclo[6.2.1.0 $\left.{ }^{2,6}\right]$ undec-3-en-7-yl)carbamoate (15)

A yellowish-white solid; yield 32\% (1.18 g); Mp: $147-148{ }^{\circ} \mathrm{C} ; \mathrm{R}_{\mathrm{f}}=0.38$ (n-hexane-EtOAc 1:2); ${ }^{1} \mathrm{H}$ NMR (400 MHz, $\left.\mathrm{CDCl}_{3}\right): \delta=1.50\left(\mathrm{~s}, 9 \mathrm{H}, \mathrm{CH}_{3}\right), 2.11\left(\mathrm{~s}, 3 \mathrm{H}, \mathrm{CH}_{3}\right), 2.17,(\mathrm{~d}, 1 \mathrm{H}, \mathrm{H}-$ 8, $J=12.6 \mathrm{~Hz}), 2.26-2.35\left(\mathrm{~m}, 1 \mathrm{H}, \mathrm{CH}_{2}\right), 2.92-3.00\left(\mathrm{~m}, 1 \mathrm{H}, \mathrm{CH}_{2}\right), 3.52(\mathrm{~d}, 1 \mathrm{H}, \mathrm{H}-7, J=9.1$ Hz), 4.30-4.39 (m, 1H, H-2), 4.70 (d, 1H, H-6, J=5.3 Hz), 4.91 (t, 1H, H-1, J=8.2 Hz), 5.42 (brs, $1 \mathrm{H}, \mathrm{N}-\mathrm{H}) .{ }^{13} \mathrm{C}$ NMR (100 MHz, DMSO): $\delta=12.4,27.3,29.0,43.3,53.8,75.9,119.1$, 122.7, 140.6, 153.4, 156.5, 177.3. Anal. Calcd. For $\mathrm{C}_{14} \mathrm{H}_{20} \mathrm{~N}_{2} \mathrm{O}_{5}$ : C, 56.75; H, 6.80; N, 9.45. Found: C, 56.52; H, 6.63; N, 9.27.

General procedure for the synthesis of hydroxylated isoxazoline-fused $\beta$ aminocarboxylates. Synthesis of compounds 8, 9 and 16

To a solution of isoxazoline-fused lactones (7 or 15) (2.66 mmole) in EtOH (10 mL), NaOEt (15 mmole) was added and the mixture was stirred at $22{ }^{\circ} \mathrm{C}$ for the time indicated in the text. The mixture was concentrated under reduced pressure, and the residue was then diluted with $\mathrm{CHCl}_{3}(30 \mathrm{~mL})$, washed with $\mathrm{H}_{2} \mathrm{O}(3 \times 15 \mathrm{~mL})$, dried $\left(\mathrm{Na}_{2} \mathrm{SO}_{4}\right)$ and concentrated under reduced pressure. The crude residue was purified by column chromatography on silica gel ( $n$ hexane-EtOAc), giving diastereoisomers 8 and $\mathbf{9}$ in 1:3 ratio or $\mathbf{1 6}$. When the reaction mixture was stirred at $0{ }^{\circ} \mathrm{C}$ for $1 \mathrm{~h}$, only the all-cis diastereoisomer (8) was detected. The product was purified by crystallization ( $n$-hexane-EtOAc).

Ethyl $\quad\left(3 \mathrm{a} S^{*}, 4 S^{*}, 6 R^{*}, 7 R^{*}, 7 \mathrm{a} S^{*}\right)-7-($ tert-butoxycarbonylamino)-4-hydroxy-3-methyl3a,4,5,6,7,7a-hexahydrobenzo $[d]$ isoxazole-6-carboxylate (8) 
A white solid, yield 75\% (670 mg); Mp: $123-124{ }^{\circ} \mathrm{C} ; \mathrm{R}_{\mathrm{f}}=0.30$ (n-hexane-EtOAc 1:3); ${ }^{1} \mathrm{H}$ NMR (400 MHz, $\left.\mathrm{CDCl}_{3}\right): \delta=1.26\left(\mathrm{t}, 3 \mathrm{H}, \mathrm{CH}_{3}, J=7.1 \mathrm{~Hz}\right), 1.44\left(\mathrm{~s}, 9 \mathrm{H}, \mathrm{CH}_{3}\right), 1.68(\mathrm{t}, 1 \mathrm{H}, \mathrm{H}-$ $6, J=12.8 \mathrm{~Hz}), 2.02\left(\mathrm{~s}, 3 \mathrm{H}, \mathrm{CH}_{3}\right), 2.02-2.10\left(\mathrm{~m}, 1 \mathrm{H}, \mathrm{CH}_{2}\right), 2.41-2.56\left(\mathrm{~m}, 1 \mathrm{H}, \mathrm{CH}_{2}\right), 3.17-3.30$ (m, 1H, H-7), 3.38 (d, 1H, H-3a, $J=9.3 \mathrm{~Hz}), 3.44-3.54(\mathrm{~m}, 1 \mathrm{H}, \mathrm{H}-7 \mathrm{a}), 4.09-4.22(\mathrm{~m}, 2 \mathrm{H}$, $\left.\mathrm{OCH}_{2}\right), 4.24-4.32$ (m, 1H, H-4), 4.91 (brs, 1H, N-H), 5.08 (brs, 1H, O-H). ${ }^{13} \mathrm{C}$ NMR (100 $\left.\mathrm{MHz}, \mathrm{CDCl}_{3}\right): \delta=12.3,14.6,28.7,32.6,39.8,52.7,56.7,58.8,61.4,64.7,80.6,155.7,157.2$ 173.9. Anal. Calcd. For $\mathrm{C}_{16} \mathrm{H}_{26} \mathrm{~N}_{2} \mathrm{O}_{6}: \mathrm{C}, 56.13 ; \mathrm{H}, 7.65 ; \mathrm{N}, 8.18$. Found: $\mathrm{C}, 55.90 ; \mathrm{H}, 7.96 ; \mathrm{N}$, 8.40 .

Ethyl $\quad\left(3 \mathrm{a} S^{*}, 4 S^{*}, 6 S^{*}, 7 R^{*}, 7 \mathrm{a} S^{*}\right)-7-($ tert-butoxycarbonylamino)-4-hydroxy-3-methyl3a,4,5,6,7,7a-hexahydrobenzo $[d]$ isoxazole-6-carboxylate $(9)$

A white solid, yield 47\% (220 mg); Mp: $140-141{ }^{\circ} \mathrm{C} ; \mathrm{R}_{\mathrm{f}}=0.58$ (n-hexane-EtOAc $\left.1: 3\right) ;{ }^{1} \mathrm{H}$ $\operatorname{NMR}\left(400 \mathrm{MHz}, \mathrm{CDCl}_{3}\right): \delta=1.26\left(\mathrm{t}, 3 \mathrm{H}, \mathrm{CH}_{3}, J=7.2 \mathrm{~Hz}\right), 1.43\left(\mathrm{~s}, 9 \mathrm{H}, \mathrm{CH}_{3}\right), 1.54-1.76(\mathrm{~m}$, 2H, $\mathrm{CH}_{2}$ ), 1.99-2.08 (m, 4H, $\left.\mathrm{CH}_{3}, \mathrm{H}-6\right), 3.18-3.30(\mathrm{~m}, 1 \mathrm{H}, \mathrm{H}-3 \mathrm{a}), 3.38$ (d, 1H, H-7, J = 8.9 Hz), 3.43-3.54 (m, 1H, H-7a), 4.09-4.20 (m, 2H, $\left.\mathrm{OCH}_{2}\right), 4.23-4.29$ (m, 1H, H-4), 4.90 (brs, 1H, N-H), 5.08 (brs, $1 \mathrm{H}, \mathrm{O}-\mathrm{H}) .{ }^{13} \mathrm{C} \mathrm{NMR}\left(100 \mathrm{MHz}, \mathrm{CDCl}_{3}\right): \delta=12.4,14.6,32.6,38.9,52.7$, 56.7, 61.4, 64.8, 80.3, 90.9, 113.2, 153.1, 157.1, 165,8. Anal. Calcd. For $\mathrm{C}_{16} \mathrm{H}_{26} \mathrm{~N}_{2} \mathrm{O}_{6}$ : C, $56.13 ; \mathrm{H}, 7.65 ; \mathrm{N}, 8.18$. Found: C, 55.92; H, 7.87; N, 8.32.

Ethyl $\quad\left(3 \mathrm{a} S^{*}, 4 R^{*}, 6 S^{*}, 7 R^{*}, 7 \mathrm{a} S^{*}\right)-7-($ tert-butoxycarbonylamino)-4-hydroxy-3-methyl3a,4,5,6,7,7a-hexahydrobenzo[d] isoxazole-6-carboxylate (16)

A white solid, yield 88\% (790 mg); Mp 118-119 ${ }^{\circ} \mathrm{C} ; \mathrm{R}_{\mathrm{f}}=0.29$ (n-hexane-EtOAc 1:3); ${ }^{1} \mathrm{H}$ $\operatorname{NMR}\left(400 \mathrm{MHz}, \mathrm{CDCl}_{3}\right): \delta=1.30\left(\mathrm{t}, 3 \mathrm{H}, \mathrm{CH}_{3}, J=7.1 \mathrm{~Hz}\right), 1.46\left(\mathrm{~s}, 9 \mathrm{H}, \mathrm{CH}_{3}\right), 1.89-2.00(\mathrm{~m}$, 2H, $\mathrm{CH}_{2}$ ), 2.09 (s, 3H, $\mathrm{CH}_{3}$ ), 2.65-2.75 (m, 1H, H-6), 2.89-3.05 (m, 1H, H-7), 3.09-3.17 (m, 1H, H-3a), 3.77-3.85 (m, 1H, H-7a), 4.11-4.29 (m, 2H, $\left.\mathrm{OCH}_{2}\right), 4.45-4.57$ (m, 1H, H-4), 4.61 $(\mathrm{dd}, 1 \mathrm{H}, \mathrm{N}-\mathrm{H}, J=3.1 \mathrm{~Hz}), 5.00(\mathrm{~d}, 1 \mathrm{H}, \mathrm{O}-\mathrm{H}, J=9.2 \mathrm{~Hz}) .{ }^{13} \mathrm{C}$ NMR $\left(100 \mathrm{MHz}, \mathrm{CDCl}_{3}\right): \delta=$ 
13.4, 14.4, 28.6, 33.6, 42.5, 49.7, 56.8, 61.7, 67.9, 80.2, 81.2, 155.5, 161.4, 174.6. Anal. Calcd. For $\mathrm{C}_{16} \mathrm{H}_{26} \mathrm{~N}_{2} \mathrm{O}_{6}$ : C, 56.13; H, 7.65; N, 8.18. Found: C, 56.32; H, 7.46; N, 8.39.

General procedure for isoxazoline ring opening. Synthesis of compounds 10, 11 and 17 To a solution of $\mathbf{8}$ or $\mathbf{9}$ or $\mathbf{1 5}$ (1.16 mmole) in $8 \mathrm{~mL}$ of EtOH/THF (3:1), $\mathrm{NiCl}_{2}$ (2.32 mmole) and $\mathrm{Boc}_{2} \mathrm{O}$ (2.32 mmole) were added. After stirring for $10 \mathrm{~min}, \mathrm{NaBH}_{4}(2.32 \mathrm{mmole})$ was added in portions, the reaction mixture was stirred at room temperature for $6 \mathrm{~h}$ and the reaction was then quenched with $\mathrm{H}_{2} \mathrm{O}(5 \mathrm{~mL})$. The reaction mixture was filtered through a silica pad and the filtrate was evaporated in vacuo. The crude residue was diluted with $\mathrm{H}_{2} \mathrm{O}$ $(30 \mathrm{~mL})$, washed with EtOAc $(3 \times 15 \mathrm{~mL})$, dried over $\mathrm{Na}_{2} \mathrm{SO}_{4}$, and concentrated under reduced pressure. The residue was then purified by column chromatography on silica gel ( $n$ hexane-EtOAc), giving 10, 11 or 17.

Ethyl $\quad\left(1 R^{*}, 2 R^{*}, 3 S^{*}, 4 S^{*}, 5 S^{*}\right)-2-($ tert-butoxycarbonylamino)-4-(1-(tert-butoxycarbonylamino)ethyl)-3,5-dihydroxycyclohexanecarboxylate (10)

A white solid, yield 58\% (300 mg); Mp 70-71 ${ }^{\circ} \mathrm{C} ; \mathrm{R}_{\mathrm{f}}=0.29$ (n-hexane-EtOAc 1:3); ${ }^{1} \mathrm{H}$ NMR (400 MHz, $\left.\mathrm{CDCl}_{3}\right): \delta=1.25-1.32\left(\mathrm{~m}, 3 \mathrm{H}, \mathrm{CH}_{3}\right), 1.37\left(\mathrm{~d}, 3 \mathrm{H}, \mathrm{CH}_{3}, J=7.0 \mathrm{~Hz}\right), 1.47(\mathrm{~s}, 9 \mathrm{H}$, $\left.\mathrm{CH}_{3}\right), 1.49\left(\mathrm{~s}, 9 \mathrm{H}, \mathrm{CH}_{3}\right), 2.32-2.40\left(\mathrm{~m}, 1 \mathrm{H}, \mathrm{CH}_{2}\right), 2.76-2.83\left(\mathrm{~m}, 1 \mathrm{H}, \mathrm{CH}_{2}\right), 3.81-4.00(\mathrm{~m}, 3 \mathrm{H}$, H-4, H-1, CH), 4.1-4.3(m, 4H, $\left.\mathrm{OCH}_{2}, \mathrm{H}-2, \mathrm{H}-5\right), 4.34-4.41$ (m, 1H, H-3), 4.60-4.69 (m, 1H, $\mathrm{N}-\mathrm{H}), 4.95$ (brs, $1 \mathrm{H}, \mathrm{N}-\mathrm{H}) .{ }^{13} \mathrm{C}$ NMR $\left(100 \mathrm{MHz}, \mathrm{CDCl}_{3}\right): \delta=14.4,18.7,28.7,28.8,30.1$, $39.5,44.6,52.1,61.6,63.0,67.0,70.7,80.1,80.6,157.7,173.6,174.1$. (ESI) $m / z=469$ $(\mathrm{M}+\mathrm{Na})$. Anal. Calcd. For $\mathrm{C}_{21} \mathrm{H}_{38} \mathrm{~N}_{2} \mathrm{O}_{8}$ : C, 56.48; H, 8.58; N, 6.27.Found: C, 56.30; H, 8.38; $\mathrm{N}, 6.40$.

Ethyl $\quad\left(1 S^{*}, 2 R^{*}, 3 S^{*}, 4 S^{*}, 5 S^{*}\right)-2-($ tert-butoxycarbonylamino)-4-(1-(tert-butoxycarbonylamino)ethyl)-3,5-dihydroxycyclohexanecarboxylate (11)

A white solid, yield $78 \%$ (400 mg); Mp: $72-73{ }^{\circ} \mathrm{C} ; \mathrm{R}_{\mathrm{f}}=0.23$ (n-hexane-EtOAc 1:2); ${ }^{1} \mathrm{H}$ $\operatorname{NMR}\left(400 \mathrm{MHz}, \mathrm{CDCl}_{3}\right): \delta=1.21-1.35\left(\mathrm{~m}, 6 \mathrm{H}, \mathrm{CH}_{3}\right), 1.41-1.47\left(\mathrm{~m}, 18 \mathrm{H}, \mathrm{CH}_{3}\right), 1.50-1.62$ 
(m, 3H, $\left.\mathrm{CH}_{2}, \mathrm{H}-1\right), 2.27-2.37$ (m, 1H, H-4), 2.72-2.78 (m, 1H, CH), 3.82 (brs, 1H, N-H), 3.89-3.95 (m, 1H, H-5), 4.06-4.25 (m, 3H, $\left.\mathrm{OCH}_{2}, \mathrm{H}-2\right), 4.30-4.37$ (m, 1H, H-3), 4.61 (brs, $1 \mathrm{H}, \mathrm{N}-\mathrm{H}) .{ }^{13} \mathrm{C}$ NMR $\left(100 \mathrm{MHz}, \mathrm{CDCl}_{3}\right): \delta=13.9,22.6,28.1,28.3,31.7,42.3,48.2,51.9$, 60.1, 65.1, 72.4, 77.0, 80.6, 92.2, 115.4, 121.0, 161.3. Anal. Calcd. For $\mathrm{C}_{21} \mathrm{H}_{38} \mathrm{~N}_{2} \mathrm{O}_{8} \mathrm{C}, 56.48$; H, 8.58; N, 6.27.Found: C, 56.36; H, 8.68; N, 6.30.

Ethyl $\quad\left(1 S^{*}, 2 R^{*}, 3 S^{*}, 4 S^{*}, 5 R^{*}\right)-2-($ tert-butoxycarbonylamino)-4-(1-(tert-butoxycarbonylamino)ethyl)-3,5-dihydroxycyclohexanecarboxylate (17)

A white solid, yield 87\% (450 mg); Mp: $75-76{ }^{\circ} \mathrm{C} ; \mathrm{R}_{\mathrm{f}}=0.63$ (n-hexane-EtOAc 1:5); ${ }^{1} \mathrm{H}$ NMR (400 MHz, $\left.\mathrm{CDCl}_{3}\right): \delta=1.21-1.31\left(\mathrm{~m}, 6 \mathrm{H}, \mathrm{CH}_{3}\right), 1.43-1.46\left(\mathrm{~m}, 18 \mathrm{H}, \mathrm{CH}_{3}\right), 1.61-1.78$ (m, 3H, $\left.\mathrm{CH}_{2}, \mathrm{H}-1\right), 2.27-2.37$ (m, 1H, H-4), 2.73-2.82 (m, 1H, CH), 3.51-3.60 (m, 1H, H-5), 4.06-4.19 (m, 3H, $\left.\mathrm{OCH}_{2}, \mathrm{H}-2\right), 4.23$ (brs, 1H, N-H), 4.29-4.32 (m, 1H, H-3), 4.88 (brs, 1H, NH). ${ }^{13} \mathrm{C} \mathrm{NMR}\left(100 \mathrm{MHz} \mathrm{CDCl}_{3}\right): \delta=13.9,22.6,28.3,28.3,31.7,42.3,48.2,51.9,60.1,65.0$, 70.2, 77.0, 80.3, 92.2, 115.4, 121.0, 161.3. Anal. Calcd. For $\mathrm{C}_{21} \mathrm{H}_{38} \mathrm{~N}_{2} \mathrm{O}_{8} \mathrm{C}, 56.48 ; \mathrm{H}, 8.58 ; \mathrm{N}$, 6.27; Found: C, 56.40; H, 8.68; N, 6.22 .

Acknowledgements: We are grateful to the Hungarian Research Foundation (OTKA No. NK81371 and KI00530) for financial support and acknowledge the receipt of a Bolyai János Fellowship for Loránd Kiss.

\section{References}

1. a) a) Kiss, L.; Fülöp, F. Synlett 2010, 1302. b) Palkó, M.; Kiss, L.; Fülöp, F. Curr. Med. Chem. 2005, 12, 3063. c) Kiss, L.; Forró, E.; Fülöp, F. Synthesis of carbocyclic $\beta$-amino acids. Amino Acids, Peptides and Proteins in Organic Chemistry. Vol. 1, Ed. A. B. Hughes, Wiley, Weinheim, 2009, 367. d) Fülöp, F. Chem. Rev. 2001, 101, 2181. 
2. a) Ishikawa, H.; Suzuki, T.; Orita, H.; Uchimaru, T.; Hayashi, Y. Chem. Eur. J. 2010, 16, 12616. b) Ko, J. S.; Keum, J. E.; Ko, S. Y. J. Org. Chem. 2010, 75, 7006. c) Karpf, M.; Trussardi, R. Angew. Chem. Int. Ed. 2009, 48, 5760. d) Satoh, N.; Akiba, T.; Yokoshima, S.; Fukuyama, T. Tetrahedron 2009, 65, 3239. e) Ishikawa, H.; Suzuki, T.; Hayashi, Y. Angew. Chem. Int. Ed. 2009, 48, 1304. f) Sullivan, B.; Carrera, I.; Drouin, M.; Hudlicky, T. Angew. Chem. Int. Ed. 2009, 48, 4229. g) Trost, B. M.; Zhang, T. Angew. Chem. Int. Ed. 2008, 47, 3759. h) Zhu, S.; Yu, S.; Wang, Y.; Ma, D. Angew. Chem. Int. Ed. 2010, 49, 4656 . i) Mohan, S.; McAtamney, S.; Haselhorst, T.; von Itzstein, M.; Pinto, B. M. J. Med. Chem. 2010, 53, 7377. j) Kamimura, A.; Nakano, T. J. Org. Chem. 2010, 75, 3133. k) Nie, L. D.; Shi, X-X.; Ko, K. H.; Lu, W-D. J. Org. Chem. 2009, 74, 3970. 1) Osato, H.; Jones, I. L.; Chen, A.; Chai, C. L. L. Org. Lett. 2010, 12, 60.

3. a) Wena, W-H.; Wang, S-Y.; Tsai, K-C.; Cheng, Y-S. E.; Yang, A-S.; Fang, J-M.; Wong, C-H. Bioorg. Med. Chem. 2010, 18, 4074. b) Xu, G.; Kiefel, M. J.; Wilson, J. C.; Andrew, P. W.; Oggioni, M. R.; Taylor, G.L. J. Am. Chem. Soc. 2011, 133, 1718. c) Calveras, J.; Nagai, Y.; Sultana, I.; Ueda, Y.; Higashi, T.; Shoji, M.; Sugai, T. Tetrahedron 2010, 66, 4284. d) Honda, T.; Kubo, S.; Masuda, T.; Arai, M.; Kobayashi, Y.; Yamashita, M. Bioorg. Med. Chem. Lett. 2009, 19, 2938. e) Soule, J-F.; Mathieu, A.; Norsikian, S.; Beau, J-M. Org. Lett. 2010, 12, 5322 .

4. a) Watson, K. G.; Cameron, R.; Fenton, R. J.; Gower, D.; Hamilton, S.; Jin, B.; Krippner, G. Y.; Luttick, A.; McConnell, D.; MacDonald, S. J. F.; Mason, A. M.; Nguyen, V.; Tucker, S. P.; Wu, W-Y. Bioorg. Med. Chem. Lett. 2004, 14, 1589. b) Li, J.; Zheng, M.; Tang, W.; He, P-L.; Zhu, W.; Li, T.; Zuo, J-P.; Liu, H.; Jiang, H. Bioorg. Med. Chem. Lett. 2006, 16, 5009. c) Wen, W-H.; Wang, S-Y.; Tsai, K-C.; Cheng, Y-S. E.; Yang, A-S.; Fang, J-M.; Wong, C-H. Bioorg. Med. Chem. 2010, 18, 4074. d) Lu, W. J.; Chen, Y. L.; Ma, W. P.; Zhang, X. Y.; Luan, F.; Liu, M. C.; Chen, X. G.; Hu, Z. D. Eur. J. Med. Chem. 2008, 43, 569. 
e) Masuda, T.; Yoshida, S.; Arai, M.; Kaneko, S.; Yamashita, M.; Honda, T. Chem. Pharm. Bull. 2003, 51, 1386. f) Honda, T.; Kubo, S.; Masuda, T.; Arai, M.; Kobayashi, Y.; Yamashita, M. Bioorg. Med. Chem. Lett. 2009, 19, 2938. g) Wyatt, P. G.; Coomber, B. A.; Evans, D. N.; Jack, T. I.; Fulton, H. E:; Wonacott, A. J.; Colman, P.; Varghese, J. Bioorg. Med. Chem. Lett. 2001, 11, 669. h) Lew, W.; Wu, H.; Chen, X.; Graves, B. J.; Escarpe, P. A.; MacArthur, H. L.; Mendel, D. B.; Kim, C. U. Bioorg. Med. Chem. Lett. 2000, 10, 1257. i) Kipassa, N. T.; Okamura, H.; Kina, K.; Hamada, T.; Iwagawa, T. Org. Lett. 2008, 10, 815. j) Weiwer, M.; Chen, C-C.; Kemp, M. M.; Linhardt, R. J. Eur. J. Org. Chem. 2009, 2611. 5. a) Lu, W. J.; Chen, Y. L.; Ma, W. P.; Zhang, X. Y.; Luan, F.; Liu, M. C.; Chen, X. G.; Hu, Z. D. Eur. J. Med. Chem. 2008, 43, 569. b) Roberts, S.; Chittapragada, M.; Pendem, K.; Leavitt, B. J.; Mahler, J. W.; Ham, Y. W. Tetrahedron Lett. 2010, 51, 1779. c) Rassu, G.; Auzzas, L.; Pinna, L.; Zambrano, V.; Zanardi, F.; Battistini, L.; Marzocchi, L.; Acquotti, D.; Casiraghi, G. J. Org. Chem. 2002, 67, 5338. d) Fernández, F.; Estévez, A. M.; Estévez, J. C.; Estévez, R. J. Tetrahedron: Asymmetry 2009, 20, 892.

6. a) Conti, P.; Caligiuri, A.; Pinto, A.; Roda, G.; Tamborini, L.; Nielsen, B.; Madsen, U.; Frydenvang, K.; Colombo, A.; De Micheli, C. Eur. J. of Med. Chem. 2007, 42, 1059. b) Mineno, T.; Miller, M. J. J. Org. Chem. 2003, 68, 6591. c) Park, K-H.; Olmstead, M. M.; Kurt, M. J. J. Org. Chem. 1998, 63, 113. d) Park, K-H.; Kurt, M. J. J. Org. Chem. 2000, 65, 3520. e) Quadrelli, P.; Piccanello, A.; Martinez, N-V.; Bovio, B.; Mella, M.; Caramella, P. Tetrahedron 2006, 62, 7370. f) Pinto, A.; Conti, P.; De Amici, M.; Tamborini, L.; Grazioso, G. Colleoni, S.; Mennini, T.; Gobbi, M.; De Micheli, C. Tetrahedron: Asymmetry 2008, 19, 867. g) Quadrelli, P.; Piccanello, A.; Mella, M.; Corsaro, A.; Pistara, V. Tetrahedron 2008, 64, 3541. h) Quadrelli, P.; Bovio, B.; Piccinini, A.; Caramella, P.; De Sarlo, F.; Machetti, F. Tetrahedron 2009, 65, 10679. i) Roda, G.; Conti, P.; De Amici, M.; He, J.; Polavarapu, P. L.; De Micheli, C. Tetrahedron: Asymmetry 2004, 15, 3079. 
7. a) Chand, P.; Kotian, P. L.; Dehghani, A.; El-Kattan, Y.; Lin, T-H.; Hutchison, T. L.; Babu, Y. S.; Bantia, S.; Elliott, A. J.; Montgomery, J. A. J. Med. Chem. 2001, 44, 4379. b) Chand, P.; Babu, Y. S.; Bantia, S.; Rowland, S.; Dehghani, A.; Kotian, P. L.; Hutchison, T. L.; Ali, S.; Brouillette, W.; El-Kattan, Y.; Lin, T-H. J. Med. Chem. 2004, 47, 1919. c) Yi, X.; Guo, Z.; Chu, F. M. Bioorg. Med. Chem. 2003, 11, 1465. d) Lu, W. J.; Chen, Y. L.; Ma, W. P.; Zhang, X. Y.; Luan, F.; Liu, M. C.; Chen, X. G.; Hu, Z. D. Eur. J. Med. Chem. 2008, 43, 569.e) Oakley, A. J.; Barrett, S.; Peat, T. S.; Newman, J.; Streltsov, V. A.; Waddington, L.; Saito, T.; Tashiro, M.; McKimm-Breschkin, J. L. J. Med. Chem. 2010, 53, 6421. f) Chand, P.; Bantia, S.; Kotian, P. L.; El-Kattan, Y.; Lin, T-H.; S. Babu, Y. S. Bioorg. Med. Chem. Lett. 2005, 13, 4071.

8 a) Cui, Y.; Jiao, Z.; Gong, J.; Yu, Q.; Zheng, X.; Quan, J.; Luo, M.; Yang, Z. Org. Lett. 2010, 12, 4. b) Yi, X.; Guo, Z.; Chu, F. M. Bioorg. Med. Chem. 2003, 11, 1465.

9. Torres, E.; Acosta-Silva, C.; Rua, F.; Alvarez-Larena, A.; Parella, T.; Branchadell, V.; Ortuno, R. M. Tetrahedron 2009, 65, 5669. (e) Fernandez, D.; Torres, E.; Aviles, F. X.; Ortuno, R. M.; Vendrell, J. Bioorg. Med. Chem. 2009, 17, 3824. (f) Fernandes, C.; Pereira, E.; Faure, S.; Aitken, D. J. J. Org. Chem. 2009, 74, 3217. (g) Fülöp, F.; Martinek, T. A.; Tóth, G. K. Chem. Soc. Rev. 2006, 35, 323. (h) Kiss, L.; Forró, E.; Sillanpää, R.; Fülöp, F. J. Org. Chem. 2007, 72, 8786. (i) Kiss, L.; Forró, E.; Martinek, T. A.; Bernáth, G.; De Kimpe, N.; Fülöp, F. Tetrahedron 2008, 64, 5036. (j) Porter, E. A.; Weisblum, B.; Gellman, S. H. J. Am. Chem. Soc. 2005, 127, 11516. (k) Roy, O.; Faure, S.; Aitken, D. J. Tetrahedron Lett. 2006, 47, 5981. (1) Rua, F.; Boussert, S.; Parella, T.; Diez-Perez, I.; Branchadell, V.; Giralt, E.; Ortuno, R. M. Org. Lett. 2007, 9, 3643. (m) D’Elia, V.; Zwicknagl, H.; Reiser, O. J. Org. Chem. 2008, 73, 3262. (1) Fernandes, C.; Faure S, Pereira, E.; Declerck, V. V.; Guillot, R.; Aitken, D. J.; Org. Lett. 2010, 12, 3606. 
10. a) Kiss, L.; Nonn, M.; Forró, E.; Sillanpää, R.; Fülöp, F. Tetrahedron Lett. 2009, 50, 2605. b) Nonn, M.; Kiss, L.; Forró, E.; Mucsi, Z.; Fülöp, F. Tetrahedron 2011, 67, 4079.

11. Forró, E.; Schönstein, L.; Kiss, L.; Vega-Peñaloza, A.; Juaristi, E.; Fülöp, F. Molecules 2010, 15, 3998.

12. Christl, M.; Huisgen, R. Chem. Ber. 1973, 106, 3345.

13. Mukaiyama, T.; Hoshino, T. J. Am. Chem. Soc. 1960, 62, 5339.

14. Conti, P.; De Amici, M.; Di Ventimiglia, S. J.; Stensbol, T. B.; Madsen, U.; Osborne, H.

B.; Russo, E.; De Sarro, G.; Bruno, G.; De Micheli, C. J. Med. Chem. 2003, 46, 3102.

15. Nonn, M.; Kiss, L.; Sillanpää, R.; Fülöp, F. Beilstein J. Org. Chem. 2012, 8, 100.

Selective nitrile oxide dipolar cycloaddition for the synthesis of highly functionalized $\beta$ aminocyclohexanecarboxylate stereoisomers

Melinda Nonn, Loránd Kiss, Reijo Sillanpää, Ferenc Fülöp
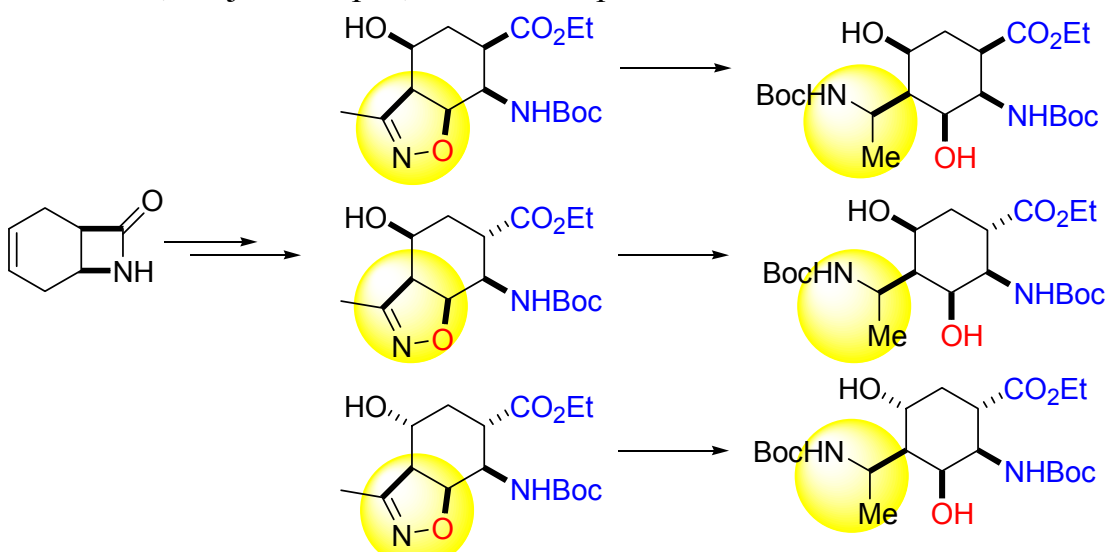
VI. 


\title{
Syntheses of Isoxazoline-Based Amino Acids by Cycloaddition of Nitrile Oxides and Their Conversion into Highly Functionalized Bioactive Amino Acid Derivatives
}

\author{
Loránd Kiss, ${ }^{a}$ Melinda Nonn, ${ }^{\mathrm{a}, \mathrm{b}}$ Ferenc Fülöp*a,b \\ a Institute of Pharmaceutical Chemistry, University of Szeged, Eötvös u. 6, 6720 Szeged, Hungary \\ Fax 3662545705; E-mail: fulop@pharm.u-szeged.hu \\ b Stereochemistry Research Group of the Hungarian Academy of Sciences, University of Szeged, Eötvös u. 6, 6720 Szeged, Hungary \\ Received: 12.04.2012; Accepted after revision: 08.05.2012
}

\begin{abstract}
The present account illustrates the syntheses of isoxazoline-based amino acids by the cycloaddition of 1,3-dipolar nitrile oxides to the $\mathrm{C}-\mathrm{C}$ double bond of unsaturated amino acid derivatives, with focus on the regio- and stereoselectivities of the transformations. Emphasis is also placed on the syntheses of highly functionalized amino acids by means of isoxazoline ring opening. The syntheses of various pharmacologically active compounds and their analogues via the above strategies are described.
\end{abstract}

1 Introduction

2 1,3-Dipolar Cycloadditions of Nitrile Oxides

3 Syntheses of Isoxazoline-Based Amino Acids

3.1 Syntheses of Isoxazoline $\alpha$-Amino Acids

3.2 Syntheses of Isoxazoline $\gamma$-Amino Acids and Their Transformation into Bioactive Derivatives

3.3 Syntheses of Isoxazoline $\beta$-Amino Acids

3.3.1 Syntheses of Highly Functionalized Cyclic $\beta$-Amino Acids by 1,3-Dipolar Cycloaddition of Nitrile Oxides

4 Cycloaddition of Nitrile Oxides to Amino Acid Precursors

5 Summary and Outlook

Key words: amino acids, amino alcohols, cycloaddition, diastereoselectivity, heterocycles, ring opening, stereoselective synthesis

\section{$1 \quad$ Introduction}

The syntheses and applications of the isoxazoline-based amino acids comprise a relatively new topic in amino acid chemistry. In consequence of their important pharmacological potential, these types of derivatives have been at the focus of interest in synthetic and medicinal chemistry during the past ten years. The aim of the present account is to provide an insight into the most relevant results relating to synthetic investigations of isoxazoline-based amino acids, with the focus mainly on the conformationally rigid analogues, and their transformation into highly functionalized derivatives with pharmacological potential.

Isoxazolines are versatile intermediates for the syntheses of a number of bioactive compounds. Substituted isoxazolines exhibit, for example, anti-influenza activity or antifungal properties. ${ }^{1} 1,3$-Dipolar cycloaddition is a method

SYNTHESIS 2012, 44, 1951-1963

Advanced online publication: 05.06 .2012

DOI: 10.1055/s-0031-1290373; Art ID: SS-2012-E0347-SR

(C) Georg Thieme Verlag Stuttgart · New York that is widely used for the construction of heterocycles, among them isoxazolines, or for the syntheses of various highly functionalized molecules.

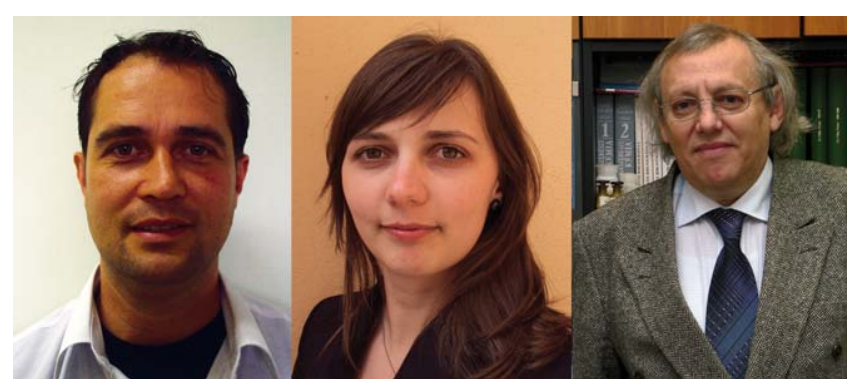

Loránd Kiss graduated chemistry in 1997 from Babes-Bolyai University, Faculty of Chemistry and Chemical Engineering (Cluj-Napoca, Kolozsvar, Romania). He received his Ph.D. degree in 2002 from Debrecen University, Department of Organic Chemistry, (Hungary) under the supervision of Professor Sándor Antus, working in the field of asymmetric syntheses of O-containing heterocyclic natural products. In 2003 he joined the research institute of Professor Ferenc Fülöp, at Institute of Pharmaceutical Chemistry, University of Szeged. He was postdoc in the laboratory of Professor Norbert De Kimpe at Ghent University, and in the laboratory of Professor Santos Fustero, Department of Organic Chemistry, University of Valencia. He is lecturer in Institute of Pharmaceutical Chemistry, University of Szeged. His recent scientific interest is directed toward the selective functionalization of alicyclic and heterocyclic $\beta$-amino acids, and stereoselective synthesis of highly functionalized carbocyclic amino alcohols.

Melinda Nonn graduated as chemist in 2007 from Babes-Bolyai University, Faculty of Chemistry and Chemical Engineering (Cluj-Napoca, Kolozsvar, Romania). In 2007 she started her Ph.D. at the Institute of Pharmaceutical Chemistry, University of Szeged (Hungary) under the supervision of Ferenc Fülöp. Her Ph.D. topic has focused on the stereoand regioselective transformations of alicyclic $\beta$-amino acids. In 2012 she became a team member of the Research Group of Stereochemistry of the Hungarian Academy of Sciences and University of Szeged. Her recent interest includes the synthesis of highly functionalized cyclic $\beta$ amino acids by 1,3-dipolar cycloaddition and the development of asymmetric synthetic methods toward the preparation of this class of derivatives.

Ferenc Fülöp was born in Szank, Hungary, in 1952. He received his M.Sc. in chemistry in 1975 and his Ph.D. in 1979, from József Attila University, Szeged, Hungary, under the supervision of Professor Gábor Bernáth. In 1991, he was appointed full professor at the Institute of Pharmaceutical Chemistry, University of Szeged, and since 1998 has been head of the Institute. He has a wide range of research interests in heterocyclic chemistry, including isoquinolines, saturated 1,3-heterocycles, and the ring-chain tautomerism of 1,3-heterocycles. His recent activities have focused on the use of amino alcohols and $\beta$-amino acids in enzymatic transformations, asymmetric syntheses, foldamer construction, and combinatorial chemistry, with a view to the development of pharmacologically active compounds. Since 2009 he has chaired a European COST action entitled 'Functional peptidomimetic foldamers: from unnatural amino acids to self-assembling nanomaterials.' 
The cycloaddition proceeds between a dipolarophile (e.g., alkenes, alkynes, carbonyls, or nitriles) and a 1,3-dipolar agent (Scheme 1).

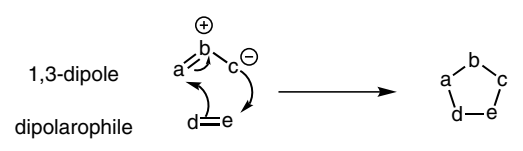

Scheme 1 General scheme of 1,3-dipolar cycloaddition

1,3-Dipoles involve three-atom $\pi$-electron systems, with four $\pi$-electrons delocalized over the three atoms. Some important 1,3-dipoles are nitrile oxides, nitrones, azides, nitrile imines, diazoalkanes, carbonyl ylides, and nitrile ylides. The 1,3-dipoles can be divided into two types: the allyl type, such as nitrones, azomethine ylides, azomethine imines, carbonyl ylides, and carbonyl imines, and the propargyl-allenyl type, such as nitrile oxides, nitrile imines, nitrile ylides, diazoalkanes, and azides (Figure 1).

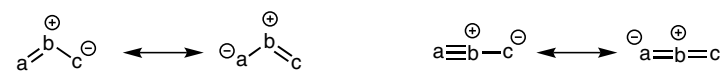

$$
\begin{aligned}
& \text { allyl type propargyl-allenyl type }
\end{aligned}
$$

Figure 1 Classification of 1,3-dipoles

The dipolarophile can be almost any compound containing a double or triple bond, such as $\mathrm{C} \equiv \mathrm{C}, \mathrm{C}=\mathrm{C}, \mathrm{C} \equiv \mathrm{N}$, $\mathrm{C}=\mathrm{N}, \mathrm{C}=\mathrm{O}$, or $\mathrm{C}=\mathrm{S}$. The cycloaddition of 1,3-dipoles to dipolarophiles may occur in a synchronous, concerted process, as proposed by Huisgen, or via a stepwise, diradical pathway, as favored by Firestone (Scheme 2). ${ }^{2}$

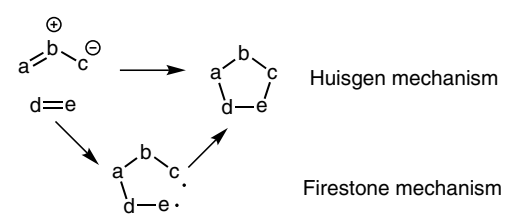

Scheme 2 Mechanisms of the 1,3-dipolar cycloaddition
2

\section{1,3-Dipolar Cycloadditions of Nitrile Oxides}

The 1,3-dipolar cycloaddition of nitrile oxides to alkenes is a powerful and efficient method for the synthesis of isoxazolines. ${ }^{3}$ Nitrile oxides are 1,3-dipoles of propargylallenyl type and their additions to yield isoxazolines may follow a concerted or a diradical mechanism. ${ }^{2 b}$

As nitrile oxides are reactive, relatively unstable dipoles, they are generated in situ in the reaction, mainly by two different routes: from hydroximoyl halides $(\mathrm{X}=\mathrm{Br}$ or $\mathrm{Cl}$, Huisgen methodology), or from primary nitroalkanes (Mukaiyama methodology) [Scheme 3 (a)]. 3a

According to the Huisgen procedure, nitrile oxides are generated from oximes in two steps: the halogenation of an aldoxime to give a hydroximoyl halide, followed by dehydrohalogenation with a base. The halogenation of oximes may be carried out, in general, with $N$-bromo- or $N$ chlorosuccinimide or sodium hypochlorite solution. ${ }^{2 a}$ Novel halogenating agents have recently been used efficiently for the generation of hydroximic acid halides: chloramine- $\mathrm{T}$, silica gel, ${ }^{4 \mathrm{a}}$ (diacetoxyiodo)benzene, and trifluoroacetic acid. ${ }^{4 \mathrm{~b}}$ The bases most commonly applied for the dehydrohalogenation are tertiary amines such as triethylamine [Scheme $3(\mathrm{~b})]^{2 \mathrm{~b}}$

The other method (that of Mukaiyama) for the in situ generation of nitrile oxides is the dehydration of primary nitroalkanes. The transformation is accomplished in the presence of a base. The dehydration agents used are phenyl isocyanate, di-tert-butyl dicarbonate, ethyl chloroformate, benzenesulfonyl chloride, dimethylaminosulfur trifluoride, acetic anhydride, etc.; in general, the base is triethylamine. A possible mechanism for the preparation of a nitrile oxide from a primary nitroalkane is shown in Scheme 3 (c). ${ }^{2}$

The cycloadditions of nitrile oxides to symmetrical alkenes are stereospecific transformations leading from $Z$ alkenes to cis-isoxazolines, and from $E$-alkenes to transisoxazolines [Scheme $4(\mathrm{a})$. $^{2 \mathrm{~b}}$
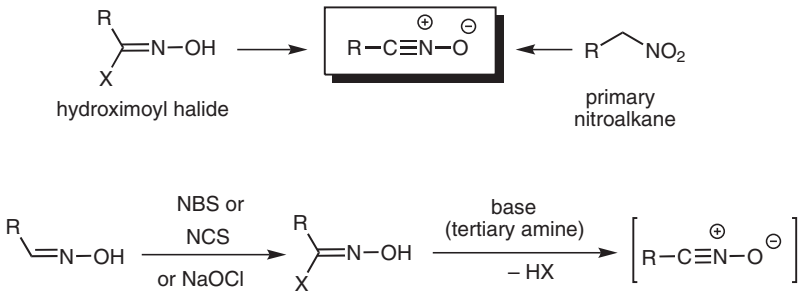

$\mathrm{X}=\mathrm{Cl}, \mathrm{Br}$

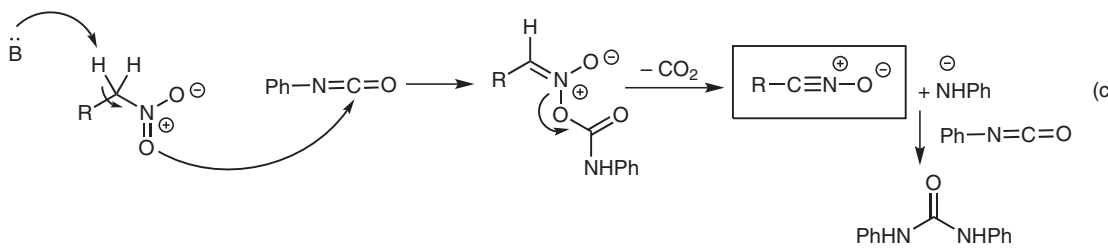

Scheme 3 Generation of nitrile oxides 


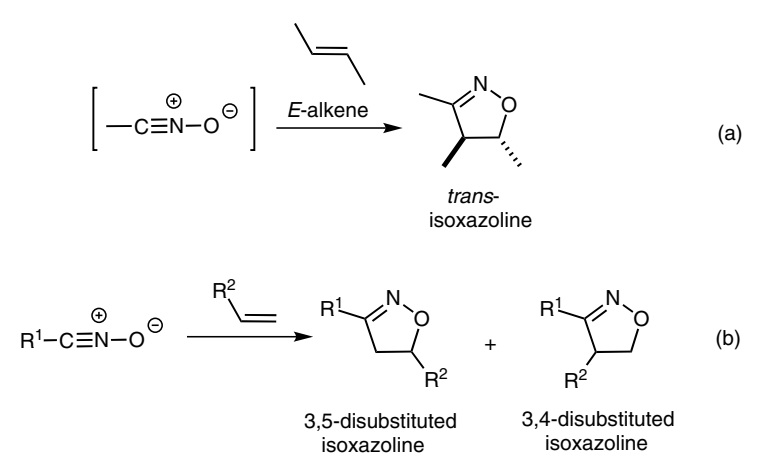

Scheme 4 Additions of nitrile oxides to alkenes

The cycloaddition of a nitrile oxide to a monosubstituted olefin can lead to two regioisomers, either the 3,4-disubstituted or the 3,5-disubstituted cycloadduct [Scheme 4 (b)], the regioselectivity being determined by steric and electronic effects. The 3,4-disubstituted isoxazoline is favored when strongly electron-withdrawing substituents are present on the dipolarophile; in the case of electrondonating substituents, formation of the 3,5-disubstituted isoxazoline is observed. ${ }^{2 a}$

When electron-rich and conjugated alkenes are applied in the cycloaddition, the regioselectivity is dipole-LUMOcontrolled. Accordingly, the carbon atom of the nitrile oxide attacks the terminal carbon atom of the alkene, resulting exclusively in the 3,5-disubstituted isoxazoline (Figure 2). In cycloadditions to electron-deficient dipolarophiles, both dipole-HOMO and dipole-LUMO interactions are significant, and mixtures of regioisomers are formed. In general, the 1,3-dipolar cycloadditions of nitrile oxides to disubstituted alkenes lead to mixtures of regioisomers. ${ }^{2 b}$

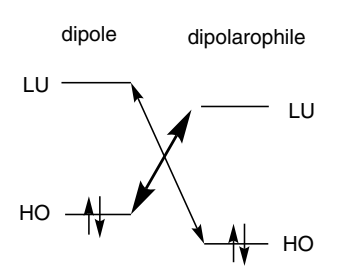

HO-controlled

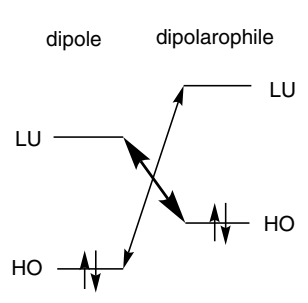

LU-controlled
Figure 2 Frontier molecular aspects of nitrile oxide cycloaddition
Isoxazolines are of considerable importance in synthetic chemistry, since they are precursors of imino alcohols, hydroxy ketones, and amino alcohols (Scheme 5). ${ }^{5}$

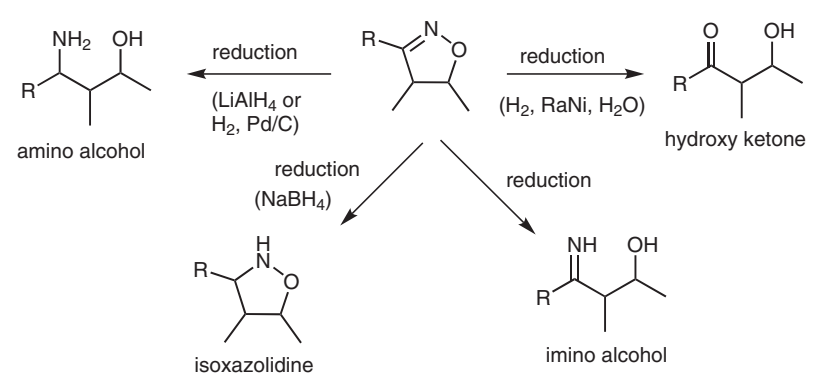

Scheme 5 Reductive transformations of isoxazolines

A wide range of reducing agents are applied in these transformations, such as $\mathrm{LiAlH}_{4}, \mathrm{NaBH}_{4}$, or catalytic hydrogenation in the presence of noble metals (Pd or Pt) or Raney nickel. ${ }^{5 a, b}$ Mild agents, such as $\mathrm{SmI}_{2}$ or $\mathrm{Fe} / \mathrm{NH}_{4} \mathrm{Cl}$, which tolerate different functional groups, have also been described for reduction of the isoxazoline ring. ${ }^{5 c, d}$ Asymmetric versions of the above reductions for the syntheses of enantiomerically pure amino alcohols or amino acids have been performed using borane/chiral ligand systems or through the reduction of readily available chiral isoxazolines..$^{\text {se-h }}$

\section{Syntheses of Isoxazoline-Based Amino Acids}

\subsection{Syntheses of Isoxazoline $\alpha$-Amino Acids}

Various isoxazoline-containing cyclopropane $\alpha$-amino acid derivatives have been synthesized via the dipolar cycloaddition of nitrile oxides and investigated as conformationally constrained homologues of glutamic acid. ${ }^{6}$

When cyclopropane $\alpha$-amino acid $\mathbf{1}$, with a vinylic $\mathrm{C}=\mathrm{C}$ bond, was subjected to dipolar cycloaddition with a nitrile oxide generated from ethyl 2-chloro-2-(hydroxyimino)acetate in the presence of sodium hydrogen carbonate as a base, the reaction resulted regioselectively in isoxazolinecontaining stereoisomers $\mathbf{2}$ and $\mathbf{3}$ with an ester group on the isoxazoline ring, in a ratio of approximately 1.5:1 (Scheme 6).

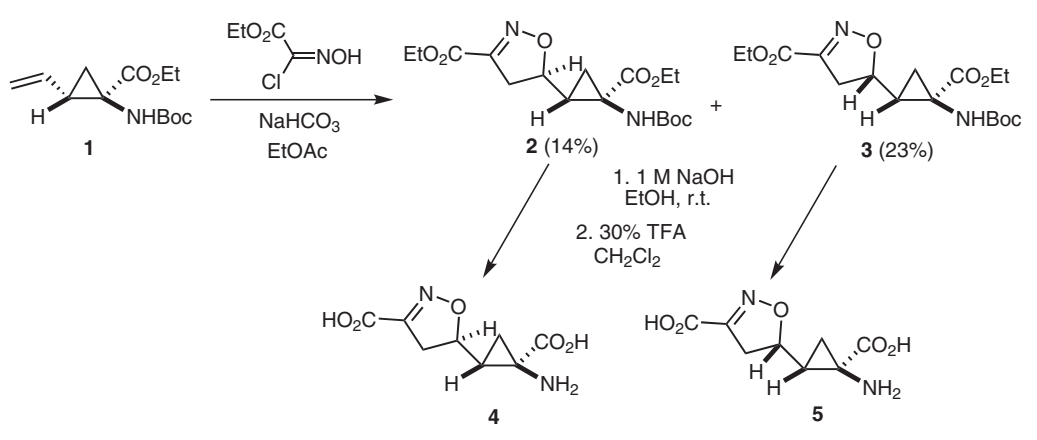

Scheme 6 


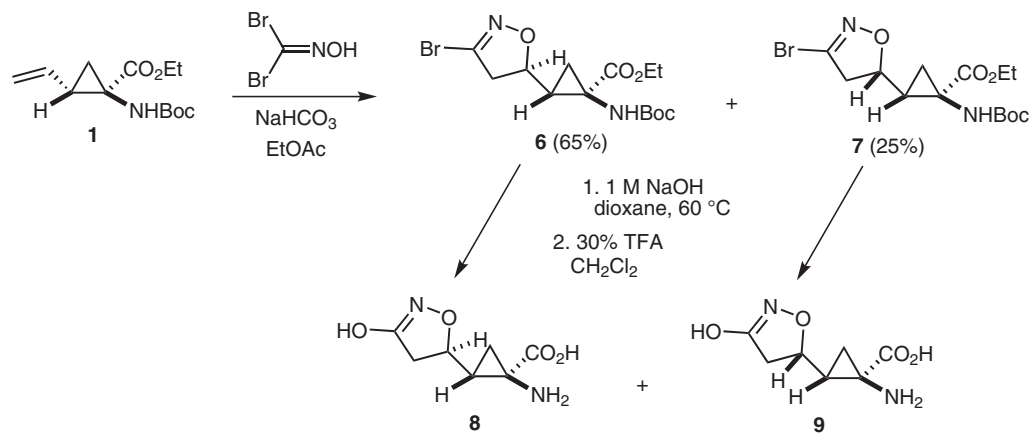

\section{Scheme 7}

Ester hydrolysis and $N$-Boc deprotection of $\mathbf{2}$ and $\mathbf{3}$ produced the isoxazoline-based cyclopropane amino acids 4 and $\mathbf{5}$ as conformationally restricted glutamate analogues.

In contrast, when the nitrile oxide was generated from dibromoformaldoxime and reacted with $\mathbf{1}$, the cycloaddition proceeded regioselectively with inverse stereoselectivity, furnishing isoxazoline-containing amino acid stereoisomers 6 and 7 in a ratio of 2.6:1 (Scheme 7). ${ }^{6}$

N-Deprotection of stereoisomers 6 and 7 with trifluoroacetic acid and hydrolysis in the presence of sodium hydroxide with replacement of the bromine on the isoxazoline skeleton afforded amino acid derivatives $\mathbf{8}$ and 9 (Scheme 7).

Conformationally restricted spiroisoxazoline-containing glutamate analogues have been synthesized by the addition of nitrile oxides [derived from ethyl 2-chloro-2(hydroxyimino)acetate or dibromoformaldoxime] to enantiomerically pure proline derivative $(S)-\mathbf{1 0}$, in which there is an extracyclic olefinic bond. In both cases, the reaction took place regioselectively, giving two stereoisomers, 11/12 and 13/14, in a ratio of $1: 3$ and $1: 4$, respectively (Scheme 8). ${ }^{6}$

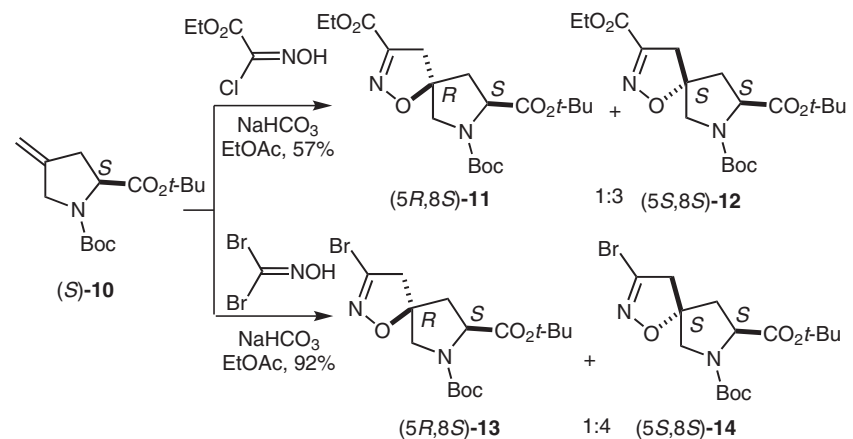

Scheme 8

These derivatives, $\mathbf{1 1} / \mathbf{1 2}$ and $\mathbf{1 3} / \mathbf{1 4}$, underwent easy transformation to the corresponding enantiomerically pure spiroisoxazoline amino acid derivatives. ${ }^{6}$

The counterpart enantiomers could be prepared via the same route, starting from enantiomerically pure $(R)-\mathbf{1 0}{ }^{6}$

Another proline derivative, $(-)-S-\mathbf{1 5}$, with the olefinic bond in the ring, was transformed by the cycloaddition of nitrile oxides to isoxazoline-fused cyclic amino acids as conformationally constrained aspartate or glutamate analogues, inhibitors of excitatory amino acid transporters. The cycloaddition of bromonitrile oxide to (-)-S-15 produced three of the four possible stereoisomers 16-18, in $13 \%, 25 \%$, and $27 \%$ yields, respectively. Compound $\mathbf{1 6}$ could be separated from $\mathbf{1 7}$ and $\mathbf{1 8}$ by chromatography (Scheme 9). ${ }^{7}$

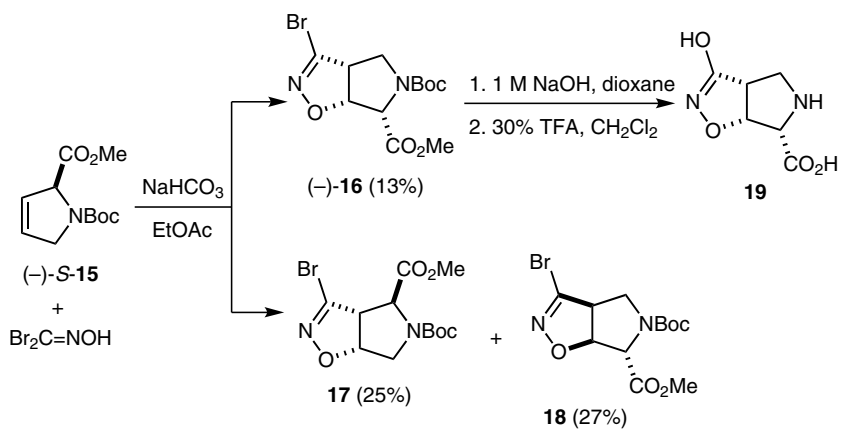

Scheme 9

Isoxazoline-containing amino acid enantiomer 19 was prepared from 16 by standard deprotection methodology (Scheme 9).

The mixture of isomers $\mathbf{1 7}$ and $\mathbf{1 8}$ was transformed to a mixture of $\mathbf{2 0}$ and 21, treatment of which with (-)-(1S)2,10-camphorsultam yielded diastereoisomers $\mathbf{2 2}$ and $\mathbf{2 3}$, which were separated by chromatography. N-Deprotection with trifluoroacetic acid, hydrolysis, and bromine removal with sodium hydroxide gave the corresponding enantiomerically pure isoxazoline-fused proline derivatives 24 and $\mathbf{2 5}$ (Scheme 10). ${ }^{7}$
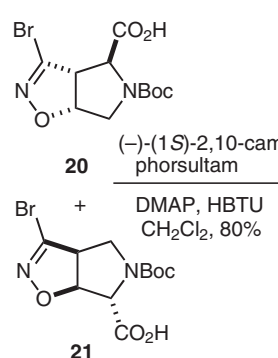

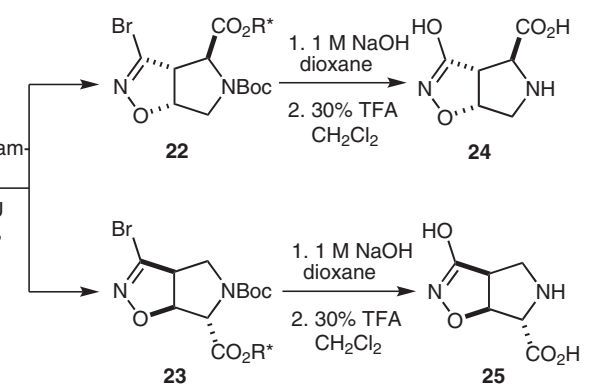

Scheme 10 
Novel acyclic isoxazoline-containing glutamate analogues that behave as $N$-methyl-D-aspartic acid (NMDA) receptor antagonists, were successfully synthesized by the addition of nitrile oxide [derived from ethyl 2-chloro-2(hydroxyimino)acetate] to unsaturated acyclic aminocarboxylate 26. The reaction, carried out under microwave irradiation conditions, led regioselectively to four isoxazoline-based amino ester stereoisomers 27-30, which were separated and isolated by chromatography (Scheme 11).

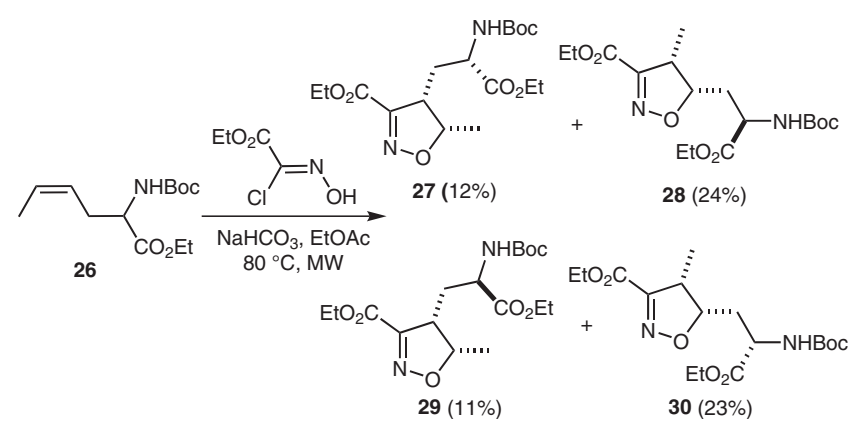

Scheme 11

These isoxazoline amino esters $\mathbf{2 7 - 3 0}$ were converted by hydrolysis and N-Boc deprotection into the corresponding amino acids. $^{8}$

The cyclopentene $\alpha$-amino ester $\mathbf{3 1}$ was a suitable starting compound for the preparation of conformationally constrained homologues of glutamic acids, which act as neuroprotective agents. On treatment with ethyl 2-chloro-2(hydroxyimino)acetate in the presence of base by the Huisgen method, the ethoxycarbonylformonitrile oxide generated by cycloaddition stereoselectively afforded isoxazoline-fused aminocyclopentanecarboxylates $\mathbf{3 2}$ and 33 in a ratio of approximately 5:1, with the carbamate and isoxazoline skeleton in a cis relationship in the major stereoisomer 32 (Scheme 12); these products were separated and isolated by chromatography.

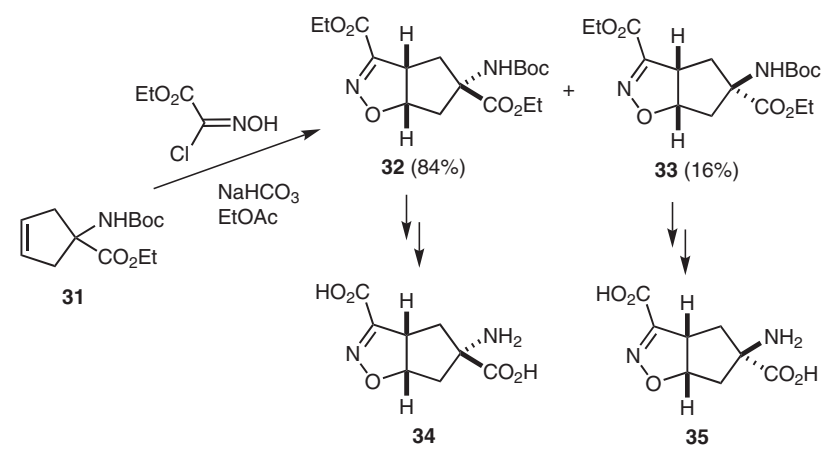

Scheme 12

The cis selectivity of the cycloaddition is explained by the $\mathrm{H}$-bond directing effect in the transition state of the reaction. The intermolecular H-bonding interaction between NHBoc and the nitrile oxide in the transition state (Figure
3) led to isoxazoline-fused derivative $\mathbf{3 2}$ as the major product.

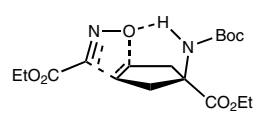

Figure 3

Through ester and N-deprotection under standard conditions, the conformationally constrained isoxazoline carboxylates 32 and $\mathbf{3 3}$ yielded amino acids $\mathbf{3 4}$ and $\mathbf{3 5}$ (Scheme 12). ${ }^{9}$

Cycloaddition to the di- $N$-Boc-protected cyclopentenecarboxylate ester $\mathbf{3 6}$ could be achieved with opposite selectivity. Because of the absence of the H-bond directing effect, the reaction was controlled by steric factors. It proceeded with inverse stereoselectivity to give isoxazolinefused carboxylates $\mathbf{3 7}$ and $\mathbf{3 8}$ in a ratio of 1:2, the major product being that in which the carbamate and isoxazoline ring were in the trans steric arrangement (Scheme 13). ${ }^{9}$

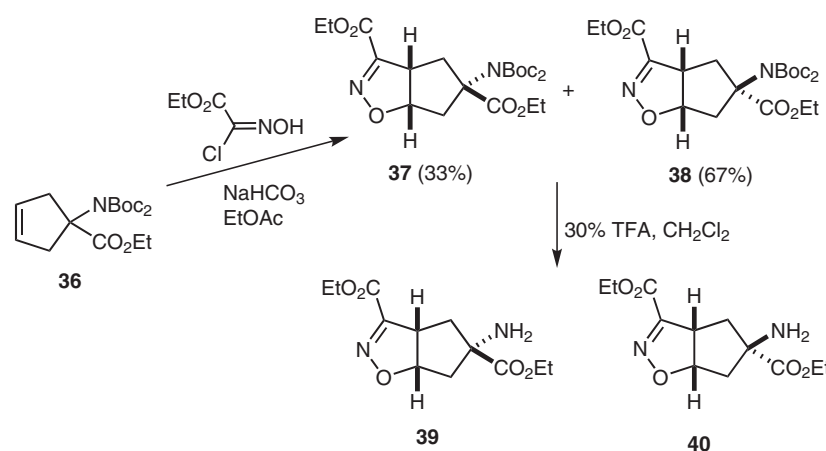

Scheme 13

Although amino esters $\mathbf{3 7}$ and $\mathbf{3 8}$ could not be separated, $\mathrm{N}$-deprotection of their mixture led to the earlier prepared amino ester 39 and a new stereoisomer 40, which were successfully separated and isolated by column chromatography.

Enantiomerically pure derivatives were synthesized by the same group of authors through the use of enzymatic resolution methods.

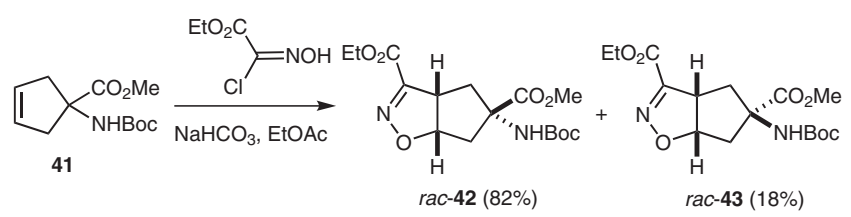

\section{Scheme 14}

The racemic cycloadducts $r a c-42$ and $r a c-43$ were obtained by the stereoselective cycloaddition of nitrile oxide to 41 (Scheme 14). When they were subjected to hydrolysis catalyzed by lipase B from Candida antarctica (CAL$\mathrm{B})$, the isoxazoline ester in $\mathrm{rac}-\mathbf{4 2}$ was transformed to the carboxylic function to furnish chemoselectively enantio- 


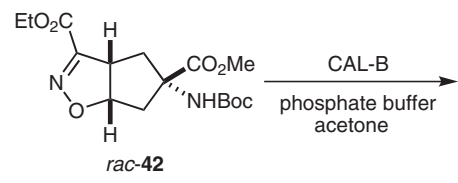

rac-42

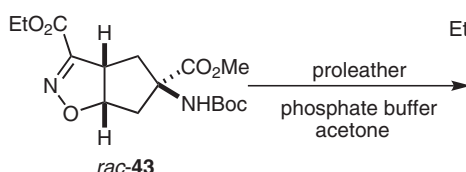

rac-43

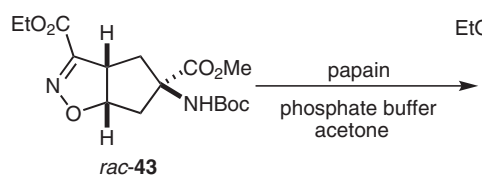

ac-43

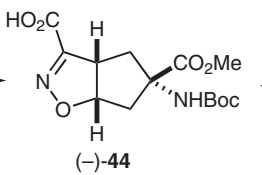

(-)-44

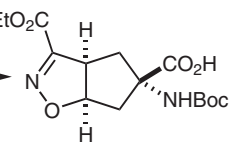

$(+)-45$

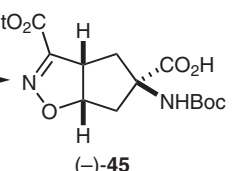

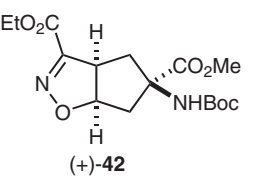

(+)-42

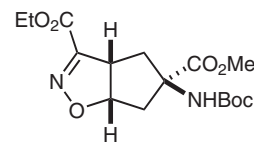

$(-)-43$

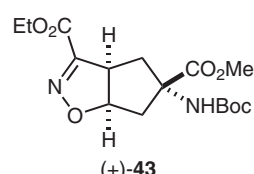

Scheme 15

mer (-)-44 and unreacted enantiomerically pure ester $(+)-$ 42. Hydrolysis of the alicyclic ester $r a c-\mathbf{4 3}$ by means of proleather chemoselective catalysis afforded amino acid enantiomer $(+)-45$ and unreacted ester enantiomer (-)-43, while papain catalyzed the hydrolysis of racemic diester rac-43 to the opposite monoacid enantiomer, (-)-45 (Scheme 15). ${ }^{10}$

These enantiomerically pure isoxazoline-fused monoacids and esters $\mathbf{4 2}-\mathbf{4 5}$ were then converted by ester hydrolysis and $\mathrm{N}$-deprotection into the corresponding optically pure bicyclic amino diacids.

In contrast with the Huisgen method, the Mukaiyama nitrile oxide generation technique provided isoxazolinefused $\alpha$-aminocyclopentanecarboxylates with higher stereoselectivity. Park and co-workers applied the Mukaiyama methodology to carry out the cycloadditions of nitrile oxides to $\alpha$-aminocyclopentenecarboxylates, the 1,3-dipolar reagents being generated from primary nitroalkanes. The nitrile oxide derived from 1-nitrobutane using phenyl isocyanate and triethylamine react with cis selectivity with urea derivative $\mathbf{4 7}$ under the control of the $\mathrm{H}$-bond directing effect of the urea moiety to furnish stereoisomers $\mathbf{4 9}$ and $\mathbf{4 8}$ in a ratio of 20:1 (5:1 by the Huisgen method), the major stereoisomer being that in which the isoxazoline and the urea displayed cis stereochemistry (Scheme 16). ${ }^{11}$

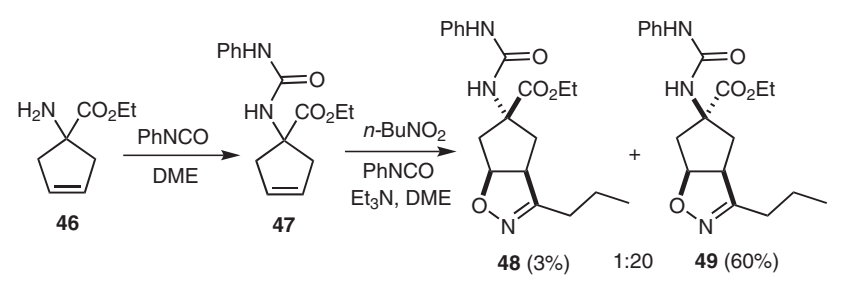

Scheme 16

The isoxazoline-fused $\alpha$-aminocyclopentanecarboxylate 48, in which the amino group and the heterocycle are trans, was obtained in only a very low amount from an Nmonoprotected (e.g., carbamate) amino ester, but this type of stereoisomer could be synthesized in a larger quantity by dipolar cycloaddition to an imino ester. Because of the absence of the H-bonding directing effect, the addition of the nitrile oxide (generated from nitrobutane/ $\mathrm{PhNCO} /$ $\left.\mathrm{Et}_{3} \mathrm{~N}\right)$ to imino ester $\mathbf{5 0}$ furnished isoxazoline-containing stereoisomers $\mathbf{5 1}$ and $\mathbf{5 2}$ in a ratio of 1:1 (Scheme 17). Since these isomers could not be separated, they were subjected to imine hydrolysis and treatment with phenyl isocyanate to give urea derivatives $\mathbf{5 5}$ and $\mathbf{5 6}$, which were separated and isolated (Scheme 17). Such compounds were subsequently transformed to cyclopentanes with hydantoin and isoxazoline moieties. ${ }^{11}$

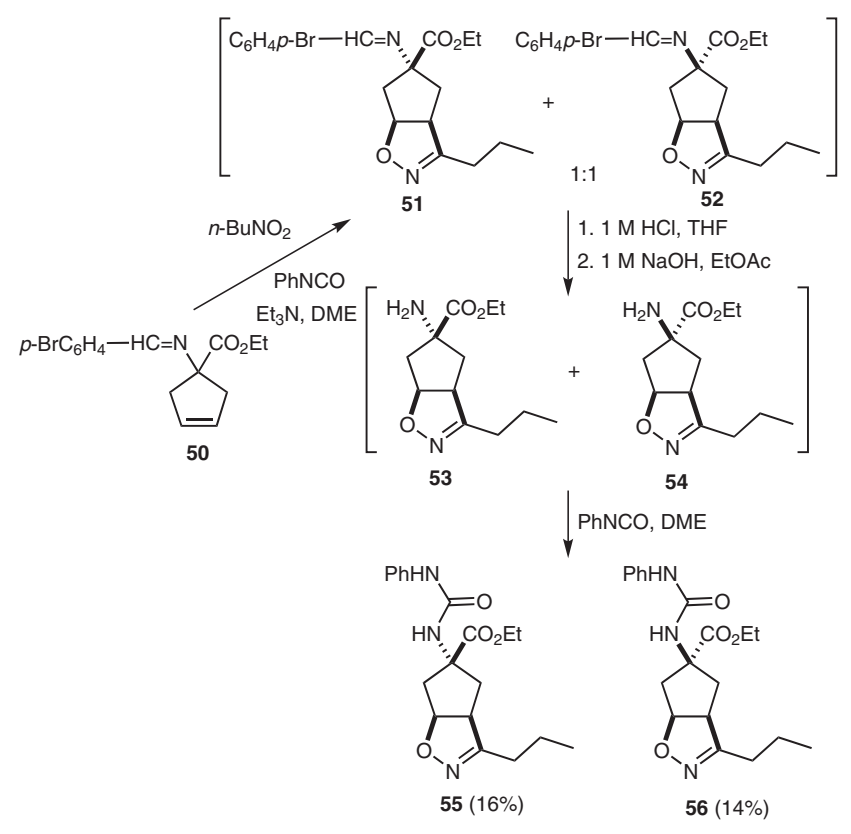

Scheme 17

Interestingly, in comparison with the additions of nitrile oxides to $\alpha$-aminocyclopentenecarboxylates (Schemes 12 and 14), addition to an $N$-Boc-protected cyclic $\alpha$-amino ester 57 possessing an extracyclic $\mathrm{C}=\mathrm{C}$ bond furnished the corresponding spiroisoxazoline cyclobutane amino esters with rather low stereoselectivity $(3: 1)$. The resulting spi- 
roisoxazolines 58 and $\mathbf{5 9}\left(\mathrm{R}=4-\mathrm{BrC}_{6} \mathrm{H}_{4}, \mathrm{Bu}, \mathrm{Ph}\right)$ were separated by chromatography (Scheme 18) and transformed into isoxazoline-substituted cyclobutanes. ${ }^{12}$

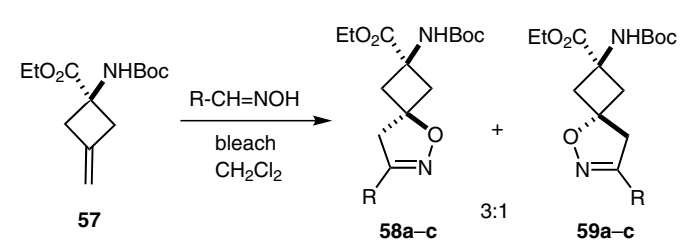

Scheme 18

Addition of the nitrile oxide generated from nitrobutane, phenyl isocyanate, and triethylamine by the Mukaiyama method to $N$-Boc-protected ethyl $\alpha$-aminocyclopentenecarboxylate $\mathbf{3 1}$ led exclusively by cis-selective addition to isoxazoline-fused $N$-Boc-amino ester $\mathbf{6 0}$, which was $\mathrm{N}$ deprotected to give amino ester $\mathbf{6 1}$ (Scheme 19). On coupling with a Boc-protected $\alpha$-aminocyclopent-3-enecarboxylic acid, $\mathbf{6 1}$ gave the dipeptidic derivative $\mathbf{6 2}$, which was subjected to nitrile oxide cycloaddition. Somewhat surprisingly, cycloaddition under the Mukaiyama conditions was not selective and afforded the corresponding cycloadducts 63 and 64 in a ratio of 1:1 (Scheme 19). ${ }^{13}$

\subsection{Syntheses of Isoxazoline $\gamma$-Amino Acids and Their Transformation into Bioactive Deriva- tives}

Intensive research investigations have been performed on the cycloaddition of various nitrile oxides to cyclopentane $\gamma$-aminocarboxylates. Since the isoxazoline-fused derivatives formed are precursors of the anti-influenza agent Peramivir (72) and its analogues, ${ }^{14}$ such syntheses are of great importance in synthetic and medicinal chemistry.

The nitrile oxide suitable for the synthesis of anti-influenza agent $\mathbf{7 2}$ was generated from 3-(nitromethyl)pentane, phenyl isocyanate, and triethylamine. Although the cycloaddition of this nitrile oxide was performed to an $N$-Bocprotected amino ester $(-)-\mathbf{6 5}$, in contrast with the earlier presented cycloadditions (e.g., to $N$-Boc-protected $\alpha$-aminocyclopentenecarboxylates), in this case the $\mathrm{H}$-bond di- recting effect was not observed. The reaction afforded four regio- and stereoisomers 66-69, the major isomer being that one in which the isoxazoline ring and the carbamate group are trans in $\mathbf{6 6}$, while the oxygen atom of the heterocycle is farthest from the carbamate (Scheme 20). ${ }^{14 a}$ This result may be explained by steric factors: due to the large alkyl chain of the nitrile oxide, steric repulsions overcome the H-bond directing effect in the transition state.

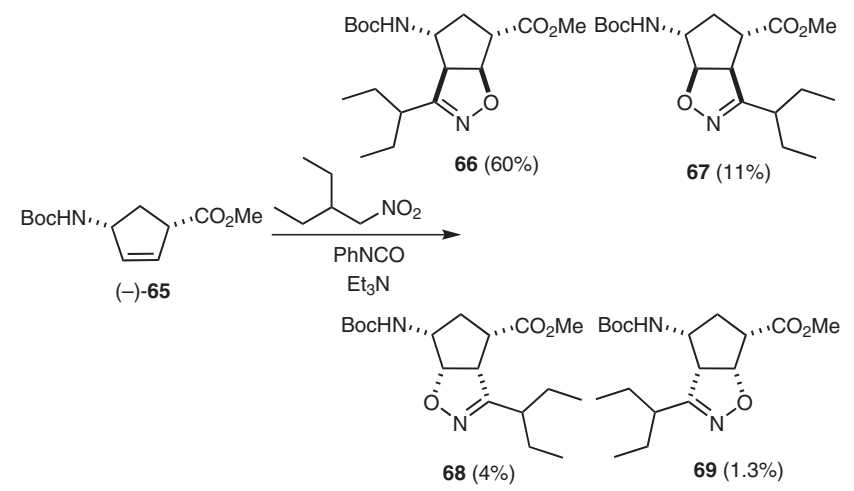

Scheme 20

The major isoxazoline-based amino ester $\mathbf{6 6}$ was separated from the other isomers by chromatography, and subsequent reductive isoxazoline opening, $N$-Boc deprotection, guanidinylation, and ester hydrolysis gave the target neuraminidase inhibitor Peramivir enantiomer (-)-72 (Scheme 21).

The isoxazoline ring-opened intermediate $\mathbf{7 0}$ was transformed by reductive removal of the cyclopentane hydroxy group to give 74, followed by deprotection and guanidinylation to give $\mathbf{7 6}$, to yield Peramivir analogue $\mathbf{7 7}$ (Scheme 22). ${ }^{14 a}$

While the additions of nitrile oxides to $\alpha$-aminocyclopentenecarboxylates were only selective under Mukaiyama conditions (cf. Schemes 13 and 19), for the corresponding $\gamma$-analogues the Huisgen method proved to be $100 \%$ regio- and stereoselective. Addition of the nitrile oxide generated from 2-ethylbutanal oxime and sodium hypo-

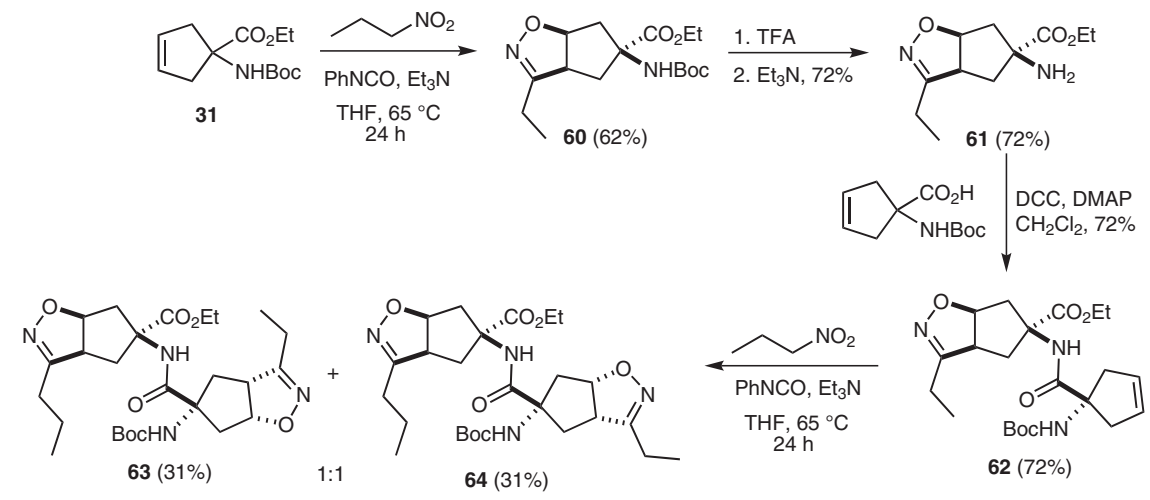

Scheme 19 


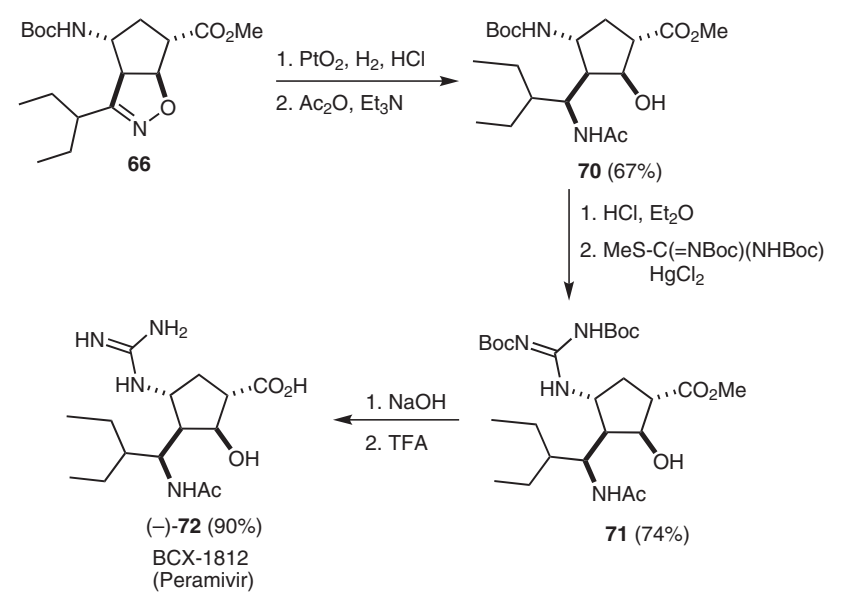

Scheme 21

chlorite in the presence of triethylamine to the cyclopentene $c i s-\gamma$-amino ester $\mathbf{6 5}$ resulted completely regio- and stereoselectively in exclusively isoxazoline-fused amino ester 66 (Scheme 23).

Compound 66 was then transformed by standard methods to racemic Peramivir rac-72. ${ }^{15}$

Peramivir analogues with a modified side chain have been prepared by the addition of the nitrile oxide generated from 4-(nitromethyl)heptane to amino ester $\mathbf{6 5}$. The major product 78 was purified by chromatography from the minor isomers (Scheme 24), and was next converted efficiently into Peramivir analogues $\mathbf{7 9}$ and 80 (Figure 4). ${ }^{16}$

Dipolar cycloadditions of nitrile oxides have likewise been applied in the syntheses of other Peramivir analogues. The nitrile oxide generated from nitropentane by addition to cyclopentenecarboxylate $\mathbf{8 1}$ resulted in isoxazoline derivatives 82 and $\mathbf{8 3}$ in a ratio of approximately $4: 1$, the major product $\mathbf{8 2}$ being favored for steric reasons (Scheme 25).

The major isomer $\mathbf{8 2}$ was subjected to isoxazoline reductive opening, followed by hydroxy-amino interconversion, guanidinylation, and deprotection to afford finally 88 (Scheme 26). ${ }^{14 a}$

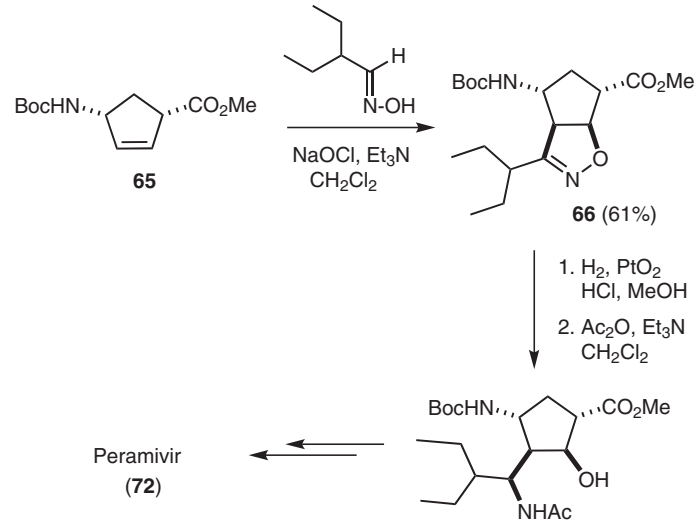

$70(82 \%)$

Scheme 23

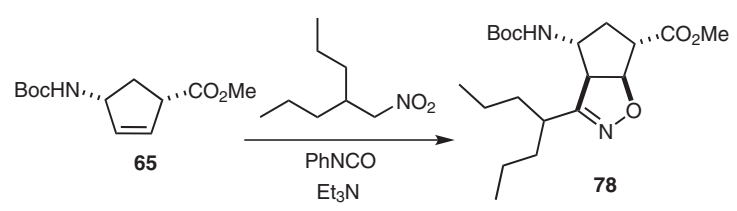

Scheme 24
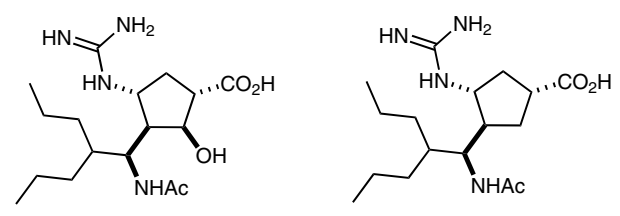

BCX-1923 (79)

BCX-1898 (80)

Figure 4

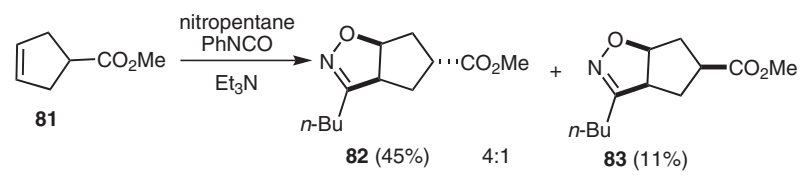

Scheme 25
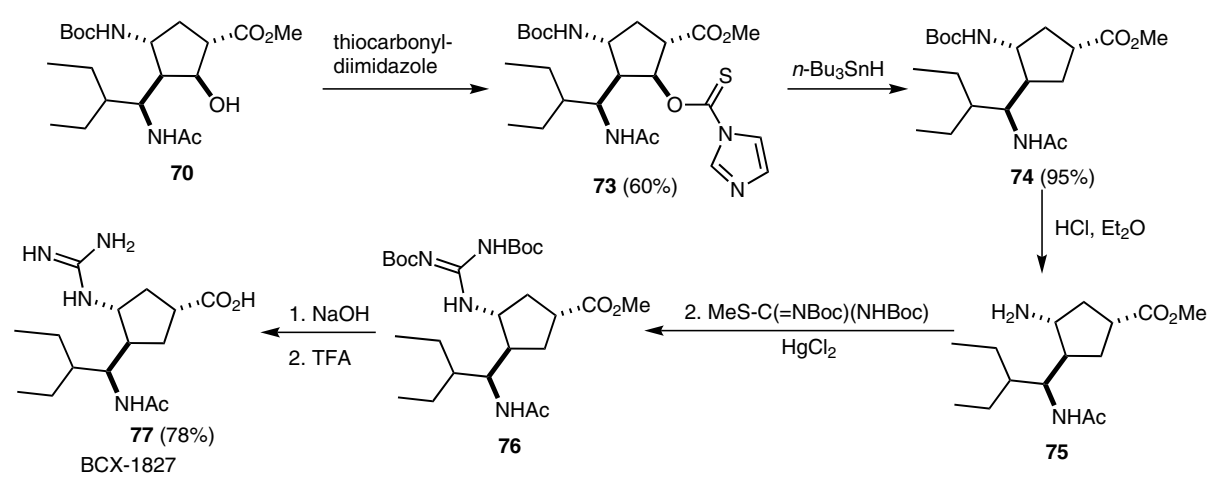

Scheme 22 


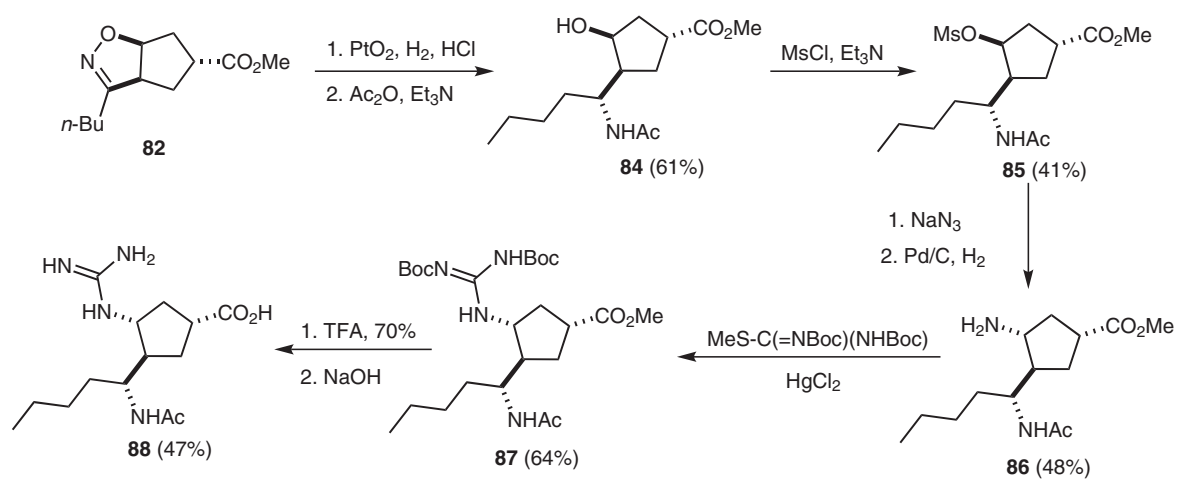

Scheme 26

\subsection{Syntheses of Isoxazoline $\beta$-Amino Acids}

In view of their valuable pharmacological properties, $\beta$ amino acids are an important class of compounds in amino acid chemistry, and have become a hot topic in synthetic and medicinal chemistry in the past 15 years. ${ }^{17}$ Cycloadditions of nitrile oxides to cycloalkene $\beta$-amino acids have been efficiently applied for their functionalization.

Addition ethyl cis-2-aminocyclopentenecarboxylate (89) and methyl- or ethyl-substituted nitrile oxides, derived from nitroethane or nitropropane and di-tert-butyl dicarbonate and 4-(dimethylamino)pyridine, gave, of the four possible isoxazoline-fused regio- and stereoisomers, three derivatives 90-92; the major stereoisomer 90 was that in which the carbamate function and isoxazoline skeleton are trans and the oxygen atom of the isoxazoline ring is farthest from the carbamate (Scheme 27). ${ }^{18}$ The selectivity was explained and supported by theoretical calculations in terms of the H-bond directing interaction in the transition state of the reaction (Figure 5). ${ }^{19}$

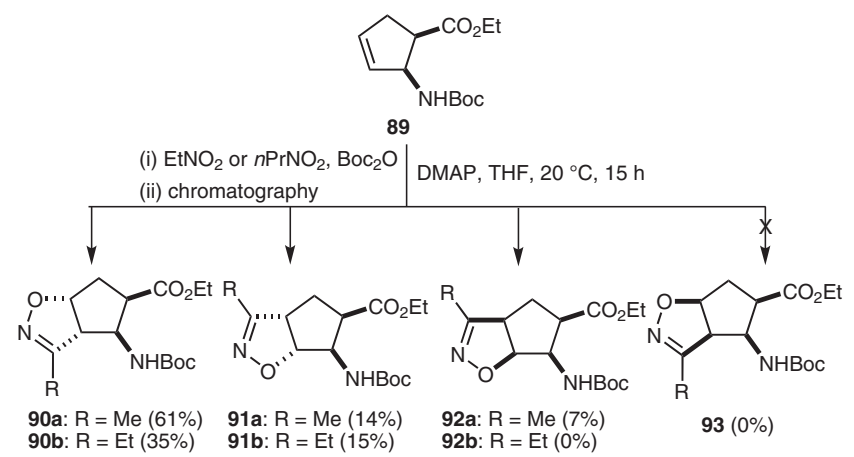

Scheme 27

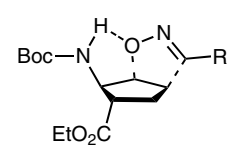

Figure 5

Interestingly, when the nitrile oxide was generated from the primary nitroalkane and phenyl isocyanate in the presence of triethylamine, the cycloadditions gave cycloadduct 90 (which was the major product under the previous conditions) with $100 \%$ regio- and stereoselectivity (Scheme 28). ${ }^{19}$ The reason for this unexpected experimental observation was not clarified.

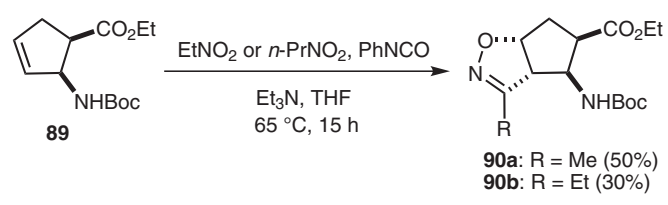

Scheme 28

The addition to cis-amino ester $\mathbf{8 9}$ was not totally selective when the nitrile oxide was generated from nitroalkane, di-tert-butyl dicarbonate, and 4-(dimethylamino)pyridine, however, a very surprising result was found when the addition was carried out with trans $\beta$-aminocyclopentenecarboxylate 94 under similar conditions. The reaction yielded, with complete regio- and stereoselectivity, isoxazoline-fused aminocyclopentanecarboxylate 95 (Scheme 29). ${ }^{19}$

In contrast to the reactions of $\mathbf{8 9}$, the addition of nitrile oxides generated from nitroalkane, phenyl isocyanate, and triethylamine to di- $N$-Boc-protected ester 99 selectively furnished, but with the opposite selectivity, low yields of isoxazoline-fused $\beta$-aminocyclopentanecarboxylates 100 (Scheme 30). ${ }^{19}$ 


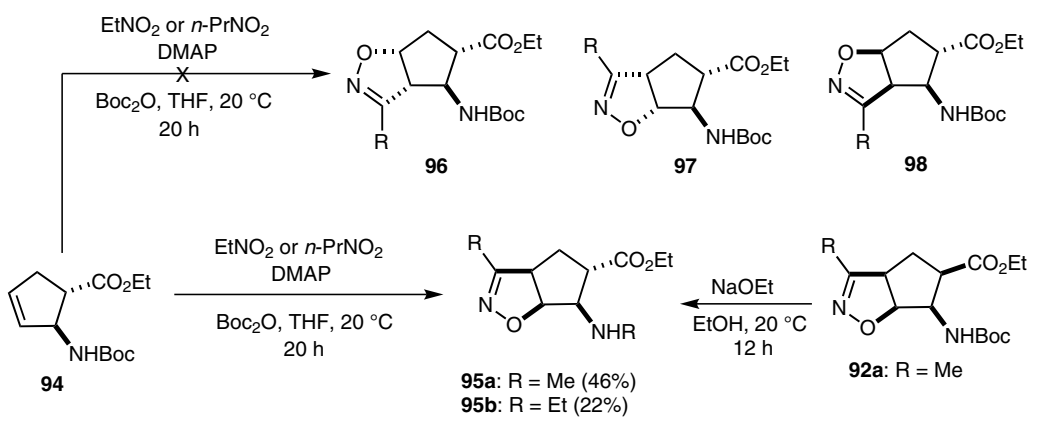

Scheme 29

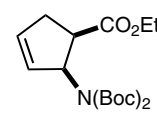

99

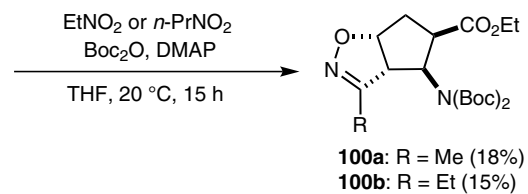

Scheme 30

\subsubsection{Syntheses of Highly Functionalized Cyclic $\beta$ - Amino Acids by 1,3-Dipolar Cycloaddition of Nitrile Oxides}

Dipolar cycloadditions of nitrile oxides have been efficiently applied to produce highly functionalized cyclic $\beta$ amino acid derivatives. Although attempts to prepare isoxazoline-fused hydroxylated $\beta$-aminocyclohexanecarboxylates 105 or 106 by the addition of nitrile oxides to the olefinic bond of hydroxylated cyclohexenecarboxylates $\mathbf{1 0 1}$ or $\mathbf{1 0 2}$ proved unsuccessful, these compounds were prepared in an alternative way, by means of the cisselective addition of nitrile oxide to the unsaturated lactone $\mathbf{1 0 3}$, followed by lactone ring opening with sodium ethoxide. Lactone ring opening at $0{ }^{\circ} \mathrm{C}$ furnished the allcis amino ester 105, while at $20^{\circ} \mathrm{C}$ epimerization occurred to give stereoisomer 106 (Scheme 31). ${ }^{20}$

Highly functionalized cyclopentane $\beta$-amino esters have been synthesized by reductive isoxazoline ring cleavage. On treatment with sodium borohydride and nickel(II) chloride, the reaction of amino ester 90a proceeded with cis selectivity to give $\mathbf{1 0 7}$ (Scheme 32).<smiles>CCOC(=O)C1C[C@@H]2ON=C(C)[C@H]2C1NC(=O)OCc1ccccc1</smiles>
$\underset{\text { EtOH-THF (3:1), r.t., } 6 \mathrm{~h}}{\stackrel{\mathrm{NaBH}_{4}, \mathrm{NiCl}_{2}, \mathrm{Boc}_{2} \mathrm{O}}{\longrightarrow}}$

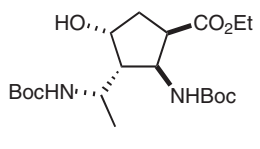

$107(80 \%)$

\section{Scheme 32}

Other multisubstituted cispentacin stereoisomers 108111 were prepared by the same protocol from isoxazolinefused 2-aminocyclopentanecarboxylates (Figure 6). ${ }^{21}$

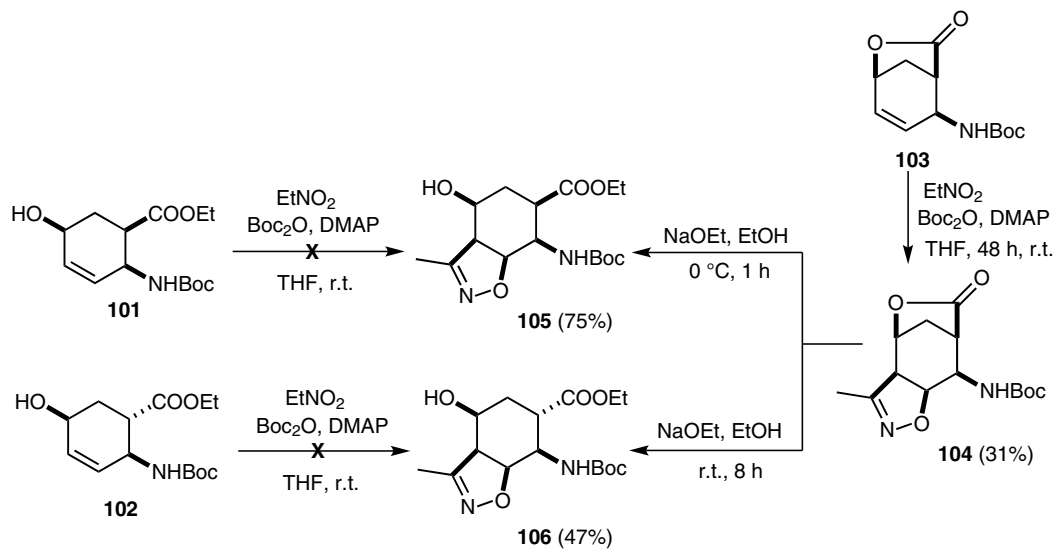

Scheme 31 
<smiles>CCO[C@H]1C[C@@H](O)[C@H]([C@H](C)NC(=O)c2ccccc2)[C@H]1N[13C](=O)[O-]</smiles><smiles>CCOC(=O)NC1[C@@H](O)C([C@H](C)NC(=O)OCc2ccccc2)C[C@H]1C(=O)OCC</smiles>

Figure 6

\section{$4 \quad$ Cycloaddition of Nitrile Oxides to Amino Acid Precursors}

Next the syntheses of isoxazoline-containing derivatives, which may be regarded as cyclic amino acid precursors, were investigated. Addition of the nitrile oxide obtained from benzhydroximoyl chloride (113) and triethylamine to azabicyclic derivative $\mathbf{1 1 2}$ stereoselectively furnished isoxazoline-fused cycloadduct regioisomers 114 and $\mathbf{1 1 5}$ in a ratio of approximately $1: 1$. After separation by chromatography, these compounds were transformed via isoxazoline amino alcohols 116 and 117, with purine and pyrimidine base construction, to a series of isoxazolinefused carbocyclic nucleosides (Scheme 33). ${ }^{22}$

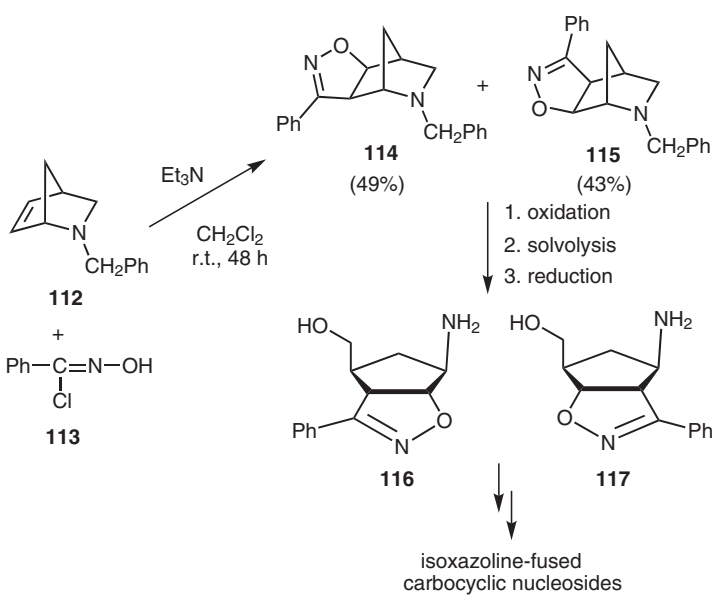

\section{Scheme 33}

Isoxazoline $\gamma$-lactams, as precursors of $\gamma$-amino acids, are readily accessible from azacyclic derivatives $\mathbf{1 1 4}$ and 115. Oxidation of these two compounds with ruthenium tetroxide and sodium periodate afforded $\gamma$-lactam derivatives $\mathbf{1 1 8} / \mathbf{1 2 0}$ and 121/123, respectively, in rather low yields. Oxidation at the benzylic position led to 119 and 122 (Scheme 34). ${ }^{23}$

On treatment with methanesulfonic acid, isoxazoline $\gamma$ lactams 118 and 121 underwent ready conversion into the corresponding isoxazoline $\gamma$-amino acid derivatives 124 and 125 (Scheme 35). ${ }^{23}$
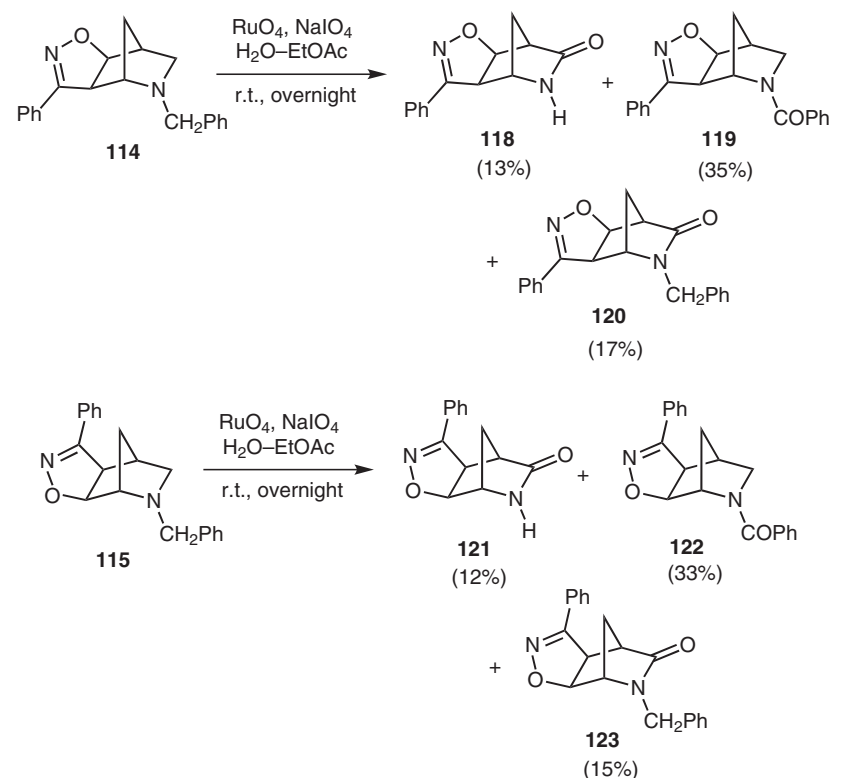

Scheme 34
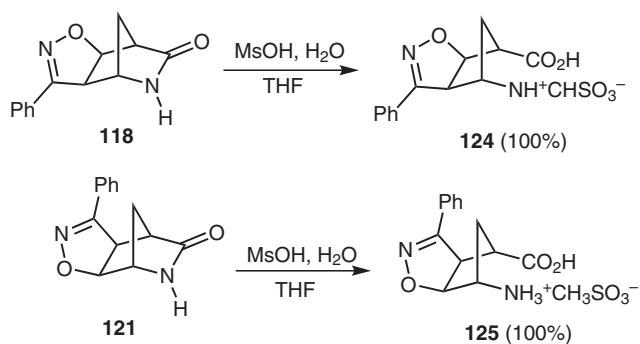

Scheme 35

In order to increase the amount of the isoxazoline $\gamma$-lactam, isoxazoline-based azacyclic regioisomers 127 and 128 were first prepared analogously to the process shown in Scheme 34, by changing the N-substituent from benzyl to methyl, ethyl, isopropyl, or tert-butyl (Scheme 36). ${ }^{24}$

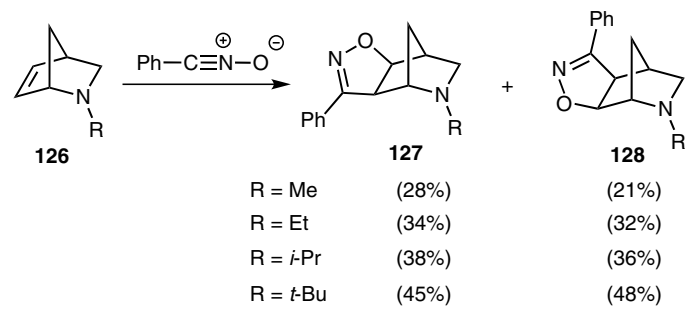

Scheme 36

Both isoxazoline regioisomers $\mathbf{1 2 7}$ and $\mathbf{1 2 8}$ were then subjected to the oxidation reaction. Though the compounds bearing an $N$-ethyl or $N$-isopropyl group gave only poor yields of the corresponding lactam, the tert-butyl derivatives of both 127 and $\mathbf{1 2 8}$ resulted selectively in only the isoxazoline $\gamma$-lactams 129 and 132 in high yields (Schemes 37 and 38). ${ }^{23}$ 


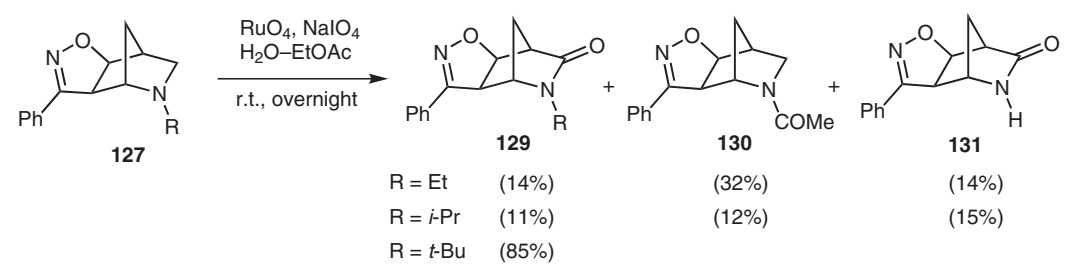

Scheme 37
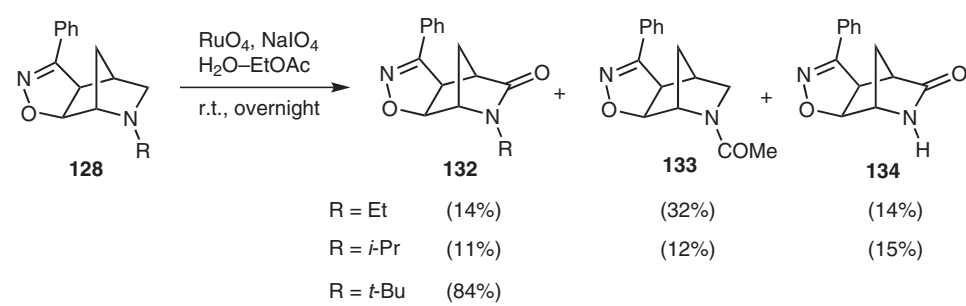

Scheme 38

\section{5}

\section{Summary and Outlook}

Highly functionalized cyclic amino acids are valuable bioactive substances and, therefore, potentially extremely important in synthetic and medicinal chemistry. The regio- and stereoselective dipolar cycloaddition of nitrile oxides is a powerful technique for construction of the isoxazoline ring, and is a widely applicable method for the functionalization of various amino acid derivatives containing an olefinic bond. Moreover, reductive isoxazoline ring cleavage offers an opportunity for access to a number of highly functionalized cyclic amino acid derivatives with the generation of new stereogenic centers, which is likely to have a considerable impact in medicinal chemistry.

\section{Acknowledgment}

We are grateful to the Hungarian Research Foundation (OTKA No. NK81371 and K100530) for financial support and acknowledge the receipt of a Bolyai János Fellowship for Loránd Kiss.

\section{References}

(1) (a) Fuller, A. A.; Chen, B.; Minter, A. R.; Mapp, A. K. J. Am. Chem. Soc. 2005, 127, 5376. (b) Bode, J. W.; Fraefel, N.; Muri, D.; Carreira, E. M. Angew. Chem. Int. Ed. 2001, 40, 2082. (c) Tangallapally, R. P.; Rakesh, D. S.; Budha, N.; Lee, R. E. B.; Lenaerts, A. J. M.; Meibohm, B.; Lee, R. E. Bioorg. Med. Chem. Lett. 2007, 17, 6638. (d) Sielecki, T. M.; Liu, J.; Mousa, S. A.; Racanelli, A. L.; Hausner, E. A.; Wexler, R. R.; Olson, R. E. Bioorg. Med. Chem. Lett. 2001, 11, 2201. (e) Gaonkar, S. L.; Rai, K. M. L.; Prabhuswamy, B. Med. Chem. Res. 2007, 15, 407. (f) Kozikowski, A. P.; Tapadar, S.; Luchini, D. N.; Kim, K. H.; Billadeau, D. D. J. Med. Chem. 2008, 51, 4370. (g) Kai, H.; Matsumoto, H.; Hattori, N.; Takase, A.; Fujiwara, T.; Sugimoto, H. Bioorg.
Med. Chem. Lett. 2001, 11, 1997. (h) Basappa, M.; Sadashiva, P.; Mantelingu, K.; Swamy, N. S.; Rangappa, K. S. Bioorg. Med. Chem. 2003, 11, 4539. (i) Lam, P. Y. S.; Adams, J. J.; Clark, C. G.; Calhoun, W. J.; Luettgen, J. M.; Knabb, R. M.; Wexler, R. R. Bioorg. Med. Chem. Lett. 2003, 13, 1795. (j) Barbachyn, M. R.; Cleek, G. J.; Dolak, L. A.; Garmon, S. A.; Morris, J.; Seest, E. P.; Thomas, R. C.; Toops, D. S.; Watt, W.; Wishka, D. G.; Ford, C. W.; Zurenko, G. E.; Hamel, J. C.; Schaadt, R. D.; Stapert, D.; Yagi, B. H.; Adams, W. J.; Friis, J. M.; Slatter, J. G.; Sams, J. P.; Oien, N. L.; Zaya, M. J.; Wienkers, L. C.; Wynalda, M. A. J. Med. Chem. 2003, 46, 284. (k) Pirrung, M. C.; Tumey, L. N.; Raetz, C. R. H.; Jackman, J. E.; Snehalatha, K.; McClerren, A. L.; Fierke, C. A.; Gantt, S. L.; Rusche, K. M. J. Med. Chem. 2002, 45, 4359.

(2) (a) Najera, C.; Sansano, J. M. Org. Biomol. Chem. 2009, 7, 4567. (b) Kissane, M.; Maguire, A. R. Chem. Soc. Rev. 2010, 39, 845 .

(3) (a) Cycloaddition Reactions in Organic Synthesis; Kobayashi, S.; Jorgensen, K. A., Eds.; Wiley-VCH: Weinheim, 2002. (b) Nitrile Oxides, Nitrones and Nitronates in Organic Synthesis; Torsell, K. B. G., Ed.; VCH: New York, 2008. (c) Pellissier, H. Tetrahedron 2007, 63, 3235. (d) Namboothiri, I. N. N.; Rastogi, N.; Ganguly, B.; Mobin, S. M.; Cojocaru, M. Tetrahedron 2004, 60, 1453. (e) Dell, C. P. J. Chem. Soc., Perkin Trans. 1 1998, 3873.

(f) Gallos, J. K.; Koumbis, A. E. Curr. Org. Chem. 2003, 7, 397. (g) Nair, V.; Suja, T. D. Tetrahedron 2007, 63, 12247. (h) Engels, B.; Christl, M. Angew. Chem. Int. Ed. 2009, 48, 7968. (i) Kanemasa, S. Synlett 2002, 1371. (j) Stanley, L. M.; Sibi, M. P. Chem. Rev. 2008, 108, 2887.

(4) (a) Shing, T. K. M.; Wong, W. F.; Cheng, H. M.; Kwok, W. S.; So, K. H. Org. Lett. 2007, 9, 753. (b) Mendelsohn, B. A.; Lee, S.; Kim, S.; Teyssler, F.; Aulakh, V. S.; Ciufolini, M. A. Org. Lett. 2009, 11, 1539.

(5) (a) Gothelf, K. V.; Jorgensen, K. A. Chem. Rev. 1998, 98 , 863. (b) Jiang, D.; Chen, Y. J. Org. Chem. 2008, 73, 9181. (c) Tang, S.; He, J.; Sun, Y.; He, L.; She, X. J. Org. Chem. 2010, 75, 1961. (d) Bode, J. W.; Carreira, E. M. Org. Lett. 2001, 3, 1587. (e) Tokizane, M.; Sato, K.; Ohta, T.; Ito, Y. 
Tetrahedron: Asymmetry 2008, 19, 2519. (f) Minter, A. R.; Fuller, A. A.; Mapp, A. K. J. Am. Chem. Soc. 2003, 125, 6846. (g) Fuller, A. A.; Chen, B.; Minter, A. R.; Mapp, A. K. J. Am. Chem. Soc. 2005, 127, 5376. (h) Sewald, N. Angew. Chem. Int. Ed. 2003, 42, 5794.

(6) Conti, P.; Caligiuri, A.; Pinto, A.; Roda, G.; Tamborini, L.; Nielsen, B.; Madsen, U.; Frydenvang, K.; Colombo, A.; De Micheli, C. Eur. J. Med. Chem. 2007, 42, 1059.

(7) Pinto, A.; Conti, P.; De Amici, M.; Tamborini, L.; Grazioso, G.; Colleoni, S.; Mennini, T.; Gobbi, M.; De Micheli, C. Tetrahedron: Asymmetry 2008, 19, 867.

(8) Pinto, A.; Conti, P.; Grazioso, G.; Tamborini, L.; Madsen, U.; Nielsen, B.; De Micheli, C. Eur. J. Med. Chem. 2011, 46, 787.

(9) Conti, P.; De Amici, M.; Joppolo di Ventimiglia, S.; Stensbol, T. B.; Madsen, U.; Bräuner-Osborne, H.; Russo, E.; De Sarro, G.; Bruno, G.; De Micheli, C. J. Med. Chem. 2003, 46, 3102.

(10) Roda, G.; Conti, P.; De Amici, M.; He, J.; Polavarapu, P. L.; De Micheli, C. Tetrahedron: Asymmetry 2004, 15, 3079.

(11) Park, K.-H.; Olmstead, M. M.; Kurth, M. J. J. Org. Chem. 1998, 63, 113.

(12) Park, K.-H.; Kurth, M. J. J. Org. Chem. 2000, 65, 352.

(13) Park, K.-H.; Olmstead, M. M.; Kurth, M. J. Synlett 2003, 1267.

(14) (a) Chand, P.; Kotian, P. L.; Dehghani, A.; El-Kattan, Y.; Lin, T.; Hutchison, T. L.; Babu, Y. S.; Bantia, S.; Elliott, A. J.; Montgomery, J. A. J. Med. Chem. 2001, 44, 4379. (b) Oakley, A. J.; Barrett, S.; Peat, T. S.; Newman, J.; Streltsov, V. A.; Waddington, L.; Saito, T.; Tashiro, M.; McKimm-Breschkin, J. L. J. Med. Chem. 2010, 53, 6421. (c) Lu, W. J.; Chen, Y. L.; Ma, W. P.; Zhang, X. Y.; Luan, F.; Liu, M. C.; Chen, X. G.; Hu, Z. D. Eur. J. Med. Chem. 2008, 43, 569. (d) Cui, Y.; Jiao, Z.; Gong, J.; Yu, Q.; Zheng, X.; Quan, J.; Luo, M.; Yang, Z. Org. Lett. 2010, 12, 4. (e) Yi, X.; Guo, Z.; Chu, F. M. Bioorg. Med. Chem. 2003, 11, 1465.
(15) Mineno, T.; Miller, M. J. J. Org. Chem. 2003, 68, 6591.

(16) (a) Chand, P.; Bantia, S.; Kotian, P. L.; El-Kattan, Y.; Lin, T.-H.; Babu, S. Y. Bioorg. Med. Chem. 2005, 13, 4071. (b) Chand, P.; Babu, Y. S.; Bantia, S.; Rowland, S.; Deghghani, A.; Kotian, P. L.; Hitchison, T. L.; Ali, S.; Brouillette, W.; El-Kattan, Y.; Lin, T.-H. J. Med. Chem. 2004, 47, 1919. (c) Yi, X.; Guo, Z.; Chu, F. M. Bioorg. Med. Chem. 2003, 11, 1465.

(17) (a) Kiss, L.; Forró, E.; Fülöp, F. Synthesis of Carbocyclic $\beta$ Amino Acids, In Amino Acids, Peptides and Proteins in Organic Chemistry; Vol. 1; Hughes, A. B., Ed.; Wiley: Weinheim, 2009, 367. (b) Kiss, L.; Fülöp, F. Synlett 2010, 1302; and references cited herein.

(18) Kiss, L.; Nonn, M.; Forró, E.; Sillanpää, R.; Fülöp, F. Tetrahedron Lett. 2009, 50, 2605.

(19) Nonn, M.; Kiss, L.; Forró, E.; Mucsi, Z.; Fülöp, F. Tetrahedron 2011, 67, 4079.

(20) Nonn, M.; Kiss, L.; Sillanpää, R.; Fülöp, F. unpublished results.

(21) Nonn, M.; Kiss, L.; Sillanpää, R.; Fülöp, F. Beilstein J. Org. Chem. 2012, 8, 100.

(22) (a) Quadrelli, P.; Picanello, A.; Martinez, N. V.; Bovio, B.; Mella, M.; Caramella, P. Tetrahedron 2006, 62, 7370. (b) Quadrelli, P.; Piccanello, A.; Mella, M.; Corsaro, A.; Pistara, V. Tetrahedron 2008, 64, 3541. (c) Quadrelli, P.; Mella, M.; Assanelli, G.; Picanello, A. Tetrahedron 2008, 64, 7312. (d) Quadrelli, P.; Bovio, B.; Piccinini, A.; Caramella, P.; De Sarlo, F.; Machetti, F. Tetrahedron 2009, 65, 10679. (e) Savion, M.; Memeo, M. G.; Bovio, B.; Grazioso, G.; Legnani, L.; Quadrelli, P. Tetrahedron 2012, 68, 1845. (f) Moggio, Y.; Legnani, L.; Bovio, B.; Memeo, M. G.; Quadrelli, P. Tetrahedron 2012, 68, 1384.

(23) Memeo, M. G.; Bovio, B.; Quadrelli, P. Tetrahedron 2011, 67, 1907.

(24) Memeo, M. G.; Mantione, D. P.; Bovio, B.; Quadrelli, P. Synthesis 2011, 2165. 